Michel Robert Veiga

DESENVOLVIMENTO DE UM GERENCIADOR ELETRÔNICO PARA MOTORES TRICOMBUSTÍVEL

São Paulo

2010 
Michel Robert Veiga

\title{
DESENVOLVIMENTO DE UM GERENCIADOR ELETRÔNICO PARA MOTORES TRICOMBUSTÍVEL
}

\author{
Dissertação apresentada à Escola \\ Politécnica da Universidade de São Paulo \\ para obtenção do título de Mestre em \\ Engenharia Elétrica.
}

Área de concentração: Microeletrônica

Orientador: Prof. Livre-Docente

Ronaldo Domingues Mansano

São Paulo

2010 
Michel Robert Veiga

\title{
DESENVOLVIMENTO DE UM GERENCIADOR ELETRÔNICO PARA MOTORES TRICOMBUSTÍVEL
}

\author{
Dissertação apresentada à Escola \\ Politécnica da Universidade de São Paulo \\ para obtenção do título de Mestre em \\ Engenharia Elétrica.
}

São Paulo 2010 
Este exemplar foi revisado e alterado em relação à versão original, sob responsabilidade única do autor e com a anuência de seu orientador.

São Paulo, 30 de setembro de 2010.

Assinatura do autor

Assinatura do orientador

FICHA CATALOGRÁFICA

Veiga, Michel Robert

Desenvolvimento de um gerenciador eletrônico para motores tricombustível / M.R. Veiga. . -- ed.rev. -- São Paulo, 2010. $138 \mathrm{p}$.

Dissertação (Mestrado) - Escola Politécnica da Universidade de São Paulo. Departamento de Engenharia de Sistemas Eletrônicos.

1. Motores de combustão interna 2. Motores a álcool 3. Combustíveis alternativos 4. Gás natural I. Universidade de São Paulo. Escola Politécnica. Departamento de Engenharia de Sistemas Eletrônicos II. t. 
Dedico esse trabalho aos meus Pais e minha futura esposa Renata. 


\section{AGRADECIMENTOS}

Primeiramente agradeço aos meus pais Vanderlina da Silva Veiga e José Milton Veiga, pelo amor e dedicação de sempre.

A minha futura esposa, Renata Aparecida Gomes Veiga, pela compreensão e dedicação em todos os momentos.

Ao meu orientador Prof. Ronaldo Domingues Mansano, pelo apoio, confiança e oportunidade cedida.

Ao Prof Armando Laganá, pelo exemplo e apoio nos testes realizados na Fatec Santo André.

Ao meu irmão Milton Robson Veiga, pela ajuda em todos os momentos.

A amiga Larissa Damiani, pela ajuda e disposição constante.

Aos meus ex-professores universitários, Prof. João Vicente Zampieron e Prof. Wagner Ideali, pelo apoio incansável em todo desenvolvimento acadêmico.

Ao amigo Eng. Carlos Alberto da Silva, pela ajuda técnica, e disposição de sempre.

Ao amigo, Leonardo Zane, pela importante ajuda desde o início do projeto.

Ao Prof Dirceu Lavoisier Graci Fernandes, pela importante atenção dispensada no meu exame de qualificação.

Aos amigos Moraes e o Prof Cleber Williams pela cooperação em diversas situações de pesquisa e por suas participações nos testes realizados nos laboratório da Fatec- Santo André.

Especiais Agradecimentos a USP (Universidade de São Paulo) pela estrutura cedida e á FATEC Santo Andre pela liberação do laboratório para testes, essenciais para o desenvolvimento do trabalho.

A todos que colaboraram direta ou indiretamente, na execução desse trabalho. 


\section{RESUMO}

O objetivo do desenvolvimento do projeto foi minimizar uma das principais desvantagens no uso do gás natural veicular, que é a perda de potência, e aumentar sua eficiência volumétrica através da construção de um circuito eletrônico capaz de gerenciar de forma eficiente a injeção do gás. O aumento do rendimento é obtido através do gerenciamento eficiente da mistura ar-combustível utilizando um sistema de malha fechada. O gerenciamento da relação de potência e economia é conseguido com o uso simultâneo de gás natural e o combustível líquido. Nos sistemas de conversão atuais e nos veículos originais a gás natural, a perda de potência é compensada desligando o sistema de gás e utilizando somente o combustível líquido, sendo esta seleção feita de forma manual na maioria dos sistemas de conversão e de forma automática no Fiat Siena tetrafuel, não possibilitando o uso simultâneo do gás com o combustível líquido. A exigência de potência é medida através do ângulo do pedal do acelerador. Quando a exigência de potência é baixa, o sistema opera apenas com gás. No momento em que há solicitação de potência intermediária, o sistema opera com diferentes proporções de etanol e gás. Na situação de solicitação de potência máxima, é utilizado apenas o combustível líquido. Foram feitas comparações entre o sistema convencional e o sistema proposto, através de ensaios dinamométricos, rodoviários e emissão de poluentes. O veículo Volkswagen Gol com seu sistema original utilizando somente etanol possui potência máxima de 64,06 cavalos, (47,77 Kilowatts) e consumo de 12,6 quilômetros por litro de etanol. Com o sistema convencional de gás natural aspirado, o consumo foi de 21 quilômetros por metro cúbico e a potência não ultrapassou 51,82 cavalos (38,64 Kilowatts), com o protótipo desenvolvido a eficiência volumétrica aumentou 25\% com consumo de 26,4 quilômetros por metro cúbico. O gerenciamento de potência proporciona potências intermediárias acima de 51,82 cavalos (38,64 Kilowatts), até a potência máxima de 64,06 cavalos (47,77 Kilowatts) em situações que uma maior potência é requerida. O sistema desenvolvido proporciona o benefício da flexibilidade no abastecimento disponível nos sistemas atuais, com a flexibilidade na potência não disponível nos sistemas atuais.

Palavras-chave: Automóvel, bicombustível, tricombustível, motor de combustão interna, injeção eletrônica, emissão de poluentes veicular, gerenciamento de motor, motores multicombustível, gerenciamento de potência. 


\begin{abstract}
This project intended to minimize one of the main disadvantages of using natural gas vehicles, which was the loss of power, and increase their volumetric efficiency by building an electronic circuit able to efficiently manage the gas injection.

The increase in volumetric efficiency is obtained through the efficient management of air-fuel mixture using a closed loop system. The management of the power and economy ratio is achieved with the simultaneous use of natural gas and liquid fuel. In the current conversion systems and original vehicles that use natural gas, the power loss is compensated by turning off the gas system and using only the liquid fuel. This selection is done manually in most conversion systems, and automatically at Fiat Siena Tetrafuel, not allowing the simultaneous use of gas to liquid fuel. The demand for power is measured by the angle of the accelerator pedal. When the power demand is low, the system operates only with natural gas. When intermediate power is required, the system operates with different proportions of ethanol and natural gas. For maximum power, only ethanol is used. Comparisons were made between the conventional and the proposed system through dynamometer tests, road tests and emission analyses. The Volkswagen Gol with original system using only ethanol has a maximum power of 64.06 horses (47.77 Kilowatts) and consumption of 12.6 kilometers per liter of ethanol. With conventional aspirated natural gas system, the consumption was $21 \mathrm{~km}$ per cubic meter and the power did not exceed 51.82 horses (38.64 Kilowatts). With the prototype, volumetric efficiency increases by $25 \%$, with consumption of 26.4 kilometers per cubic meter. The power management provides intermediate powers up to 51.82 horses (38.64 Kilowatts) until the maximum power of 64.06 horses (47.77 Kilowatts) in situations where more power is required. The developed system provides the benefit of refueling flexibility found in the original system, with power flexibility not available in original systems.
\end{abstract}

Keywords: vehicle, car, bi-fuel, tri-fuel, internal combustion engine, fuel injection system, vehicle pollutant emission, engine management, multi-fuel engines, power management. 


\section{LISTA DE ILUSTRAÇÕES}

Figura 1 - Primeiro carro produzido por Henry Ford [3] . ................................................ 26

Figura 2 - A evolução dos combustíveis no Brasil[7] . ........................................................28

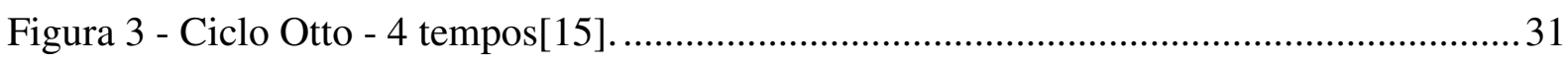

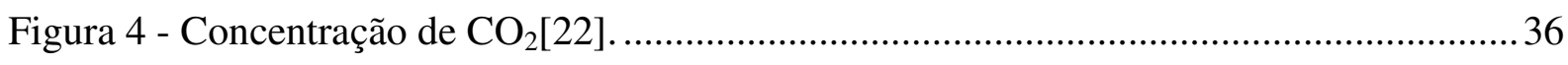

Figura 5 - Esquema de alimentação com combustível pré-vaporizado [27]...........................41

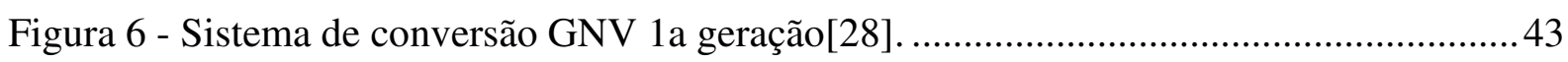

Figura 7 - Sistema de conversão GNV de $2^{\text {a }}$ geração [28] .....................................................4

Figura 8 - Sistema de conversão GNV de $3^{\text {a }}$ geração [28] ................................................. 45

Figura 9 - Sistema de conversão GNV de $4^{\text {a }}$ geração [28] ................................................... 46

Figura 10 - Sistema de conversão GNV de $5^{\text {a }}$ geração [28] ................................................. 47

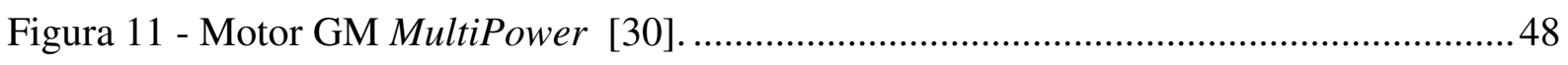

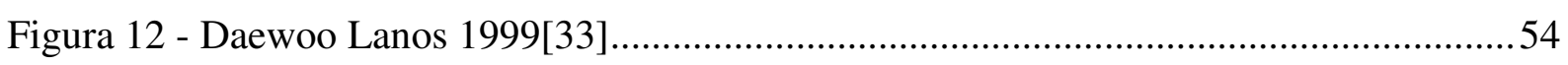

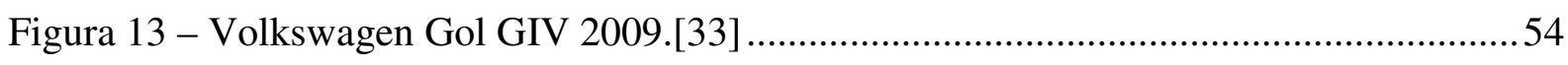

Figura 14 - Analisador de gases TM132 Tecnomotor[33] ................................................56

Figura 15 - Dispositivo de aquisição de sinais USB-6009.[33] ............................................56

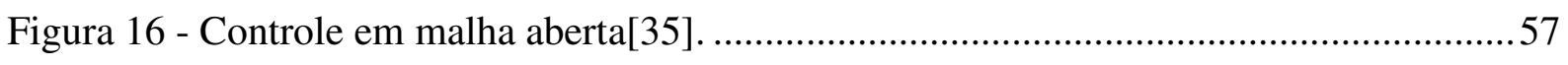

Figura 17 - Controle em malha fechada[35] .....................................................................5

Figura 18 - Sensores e atuadores de uma injeção eletrônica básica[36]. .................................59

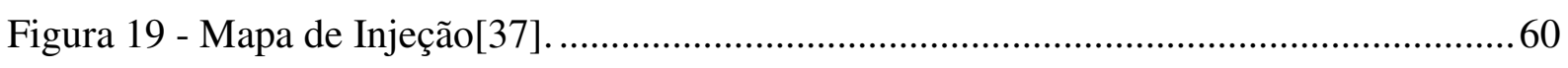

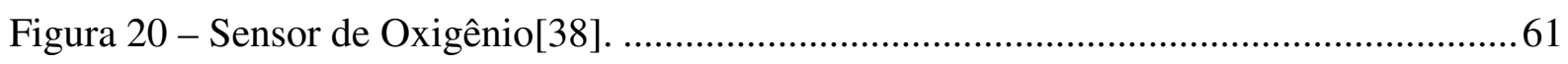

Figura 21 - Sensor de oxigênio e sua instalação[38] ..........................................................62

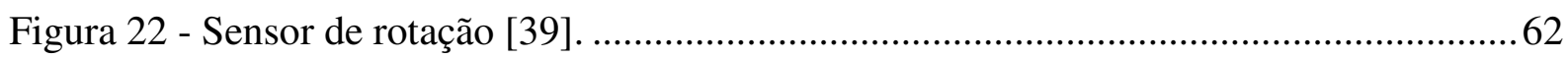

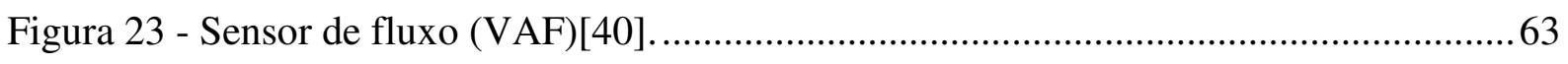

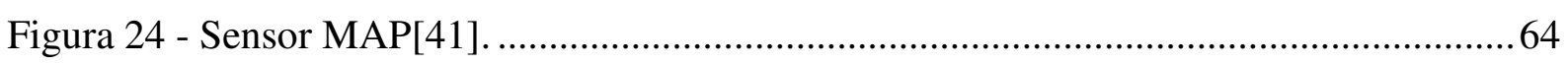

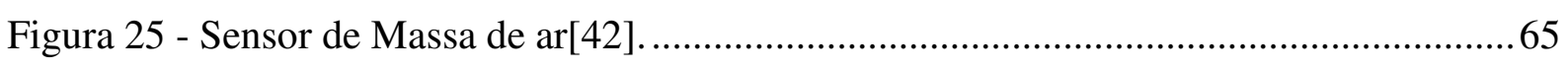

Figura 26 - Válvula de injeção ou bico injetor[29]. ............................................................66

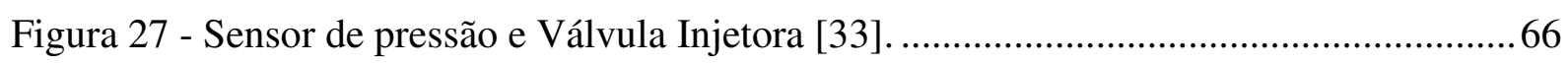

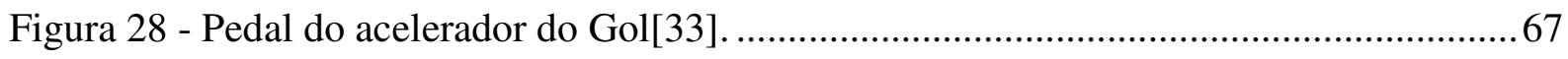

Figura 29- Esquema básico do gerenciador tricombustível e seus atuadores [33].................69

Figura 30 - Esquema do gerenciador tricombustível, atuadores e sensores[33]. ...................69 
Figura 31 - Disposição esquemática do protótipo do gerenciador tricombustível - pressão positiva[33].

Figura 32 - Diagrama esquemático das linhas de combustíveis [33]. 72

Figura 33 - Circuito protótipo do gerenciador tricombustível com injeção positiva de

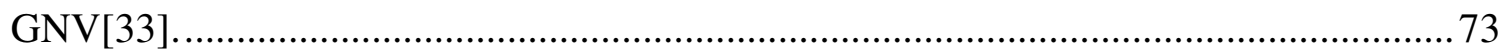

Figura 34 - Protótipo da Unidade Principal[33] ................................................................... 74

Figura 35 - Leiaute do Circuito da placa principal[43] ........................................................ 74

Figura 36 - Simulação em 3D da placa de circuito impresso da unidade principal[43]..........75

Figura 37 - Circuito Amplificador para o sinal da sonda lambda[43]................................... 75

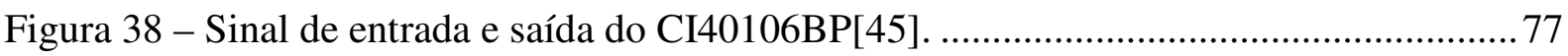

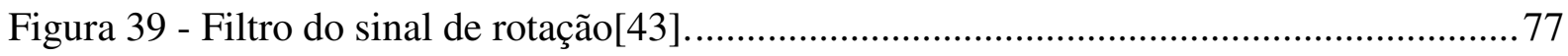

Figura 40 - Gráfico do sinal de rotação sem filtro[33]....................................................... 78

Figura 41 - Sinal de rotação após filtro[33] ........................................................................ 78

Figura 42 - Leiaute do Circuito da unidade de potência[43] ................................................ 79

Figura 43 - Simulação em 3D do circuito impresso da unidade de potência [43]................... 79

Figura 44 - Circuito eletrônico do display de LCD com comunicação serial[43]................... 80

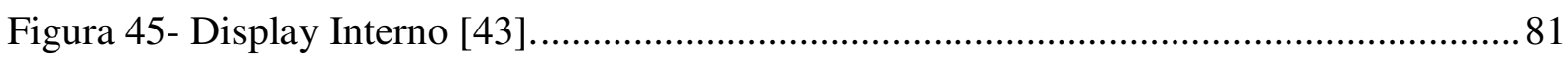

Figura 46 - Imagem em 3D da Placa de Circuito impresso [43] ......................................... 81

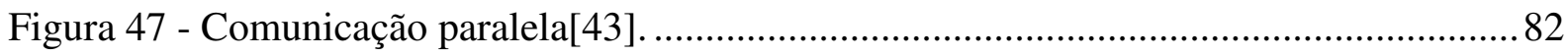

Figura 48 - Cilindro de 7,5m³ , instalado no porta malas do Daewoo Lanos[33] .................. 87

Figura 49 - Cilindro de 7,5m² , instalado no porta malas VW Gol[33] ................................87

Figura 50 - Instalação da válvula de abastecimento instalada no Daewoo Lanos[33]. ........... 88

Figura 51 - Redutor de Pressão instalado no Daewoo Lanos[33]. ......................................... 88

Figura 52 - Instalação da válvula de fluxo para alta rotação no Daewoo Lanos[33]............... 89

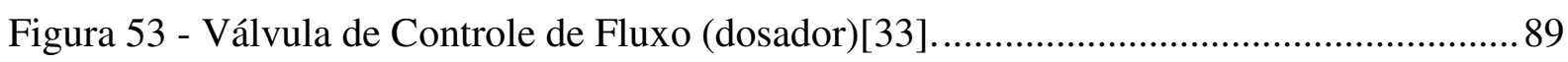

Figura 54 - Misturador de GNV utilizado no Daewoo Lanos[33]. ........................................90

Figura 55 - Instalação do Misturador no VW Gol[33]..........................................................90

Figura 56 - Instalação da Chave Comutadora no Daewoo Lanos[33]....................................91

Figura 57 - Chave Comutadora Instalada no Daewoo Lanos[33] ..........................................91

Figura 58 - Esquema de Ligação do sistema de tricombustível[33] ......................................92

Figura 59 - Esquema simplificado do gerenciador tricombustível[33] ................................93

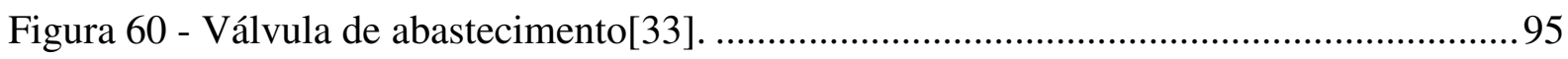

Figura 61 - Redutor de pressão para sistema de pressão positiva[33]....................................96 
Figura 62 - Furação do coletor do Daewoo Lanos para instalação das válvulas injetoras[33]. 97

Figura 63 - Válvulas injetoras de GNV instalados no Daewoo Lanos[33]...........................97

Figura 64 - Instalação do sistema de GNV com pressão positiva no VW Gol[33]..................98

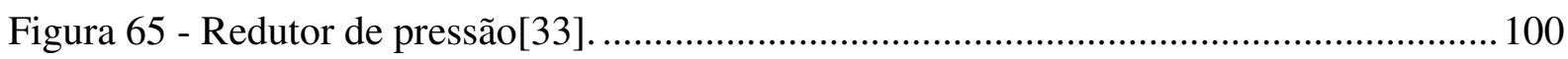

Figura 66 - Licenciamento do Daewoo Lanos tricombustível[33] ...................................... 134

Figura 67 - Certificado de inspeção veículo do Daewoo Lanos[33].................................... 135

Figura 68 - Licenciamento do VW Gol tricombustível[33].............................................. 136

Figura 69 - Certificado de aprovação de inspeção ambiental[33] .......................................136

Figura 70 - Certificado de Inspeção inicial, VW Gol [33] ................................................. 137 


\section{LISTA DE GRÁFICOS}

Gráfico 1 - Potência X Combustível, para o Corsa Multipower[30]......................................50

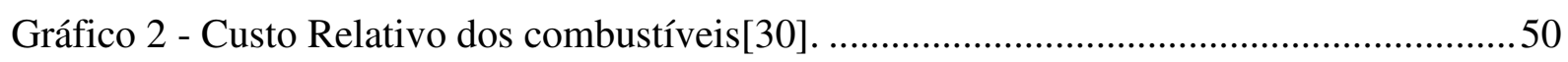

Gráfico 3 - Preço médio dos combustíveis na cidade de São Paulo em 2009[31]...................51

Gráfico 4 - Preço médio dos combustíveis no Brasil em 2009[31] .........................................52

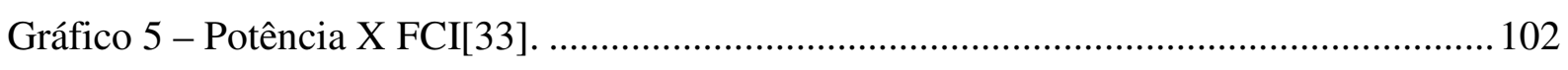

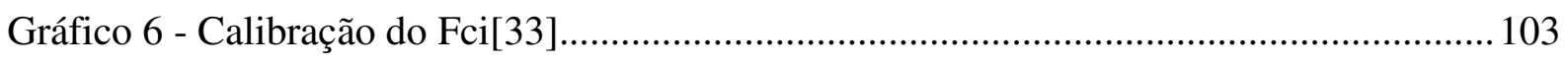

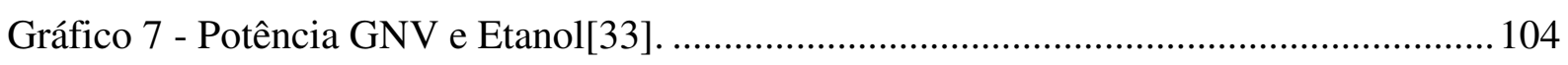

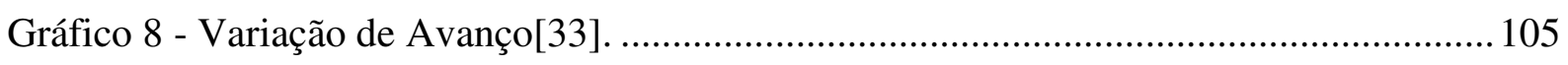

Gráfico 9 - Potência X MisturaX Correção do avanço [33] ................................................. 107

Gráfico 10 - Potência, avanço e mistura em \%, para uma rotação média de 2000 a 2500

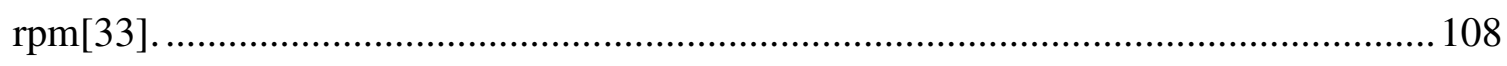

Gráfico 11 - Potência, avanço e mistura em \%, para uma rotação média de 2500 a 3000

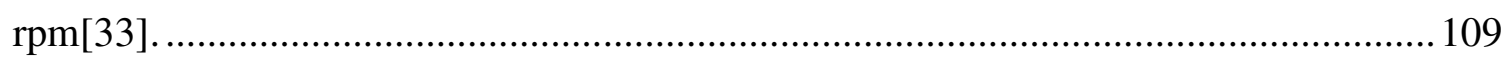

Gráfico 12 - Potência, avanço e mistura em \%, para uma rotação média de 3000 a 3500

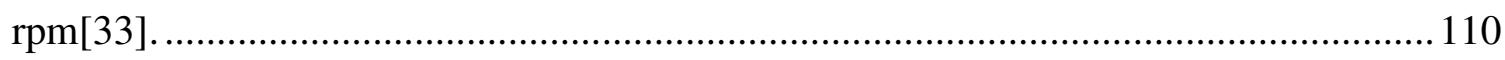

Gráfico 13 - Potência, avanço e mistura em \%, para uma rotação média de 3500 a 4000

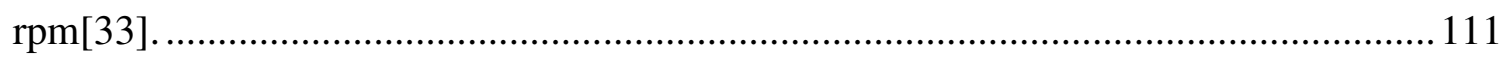

Gráfico 14 - Potência, avanço e mistura em \%, para uma rotação média de 4000 a 4500 rpm [33]. 112

Gráfico 15 - Potência, avanço e mistura em \%, para uma rotação média de 4500 a 5000 rpm [33].

Gráfico 16 - Potência, avanço e mistura em \%, para uma rotação média de 5000 a 5500 rpm [33].

Gráfico 17 - Potência, avanço e mistura em \%, para uma rotação média de 5500 a 6000

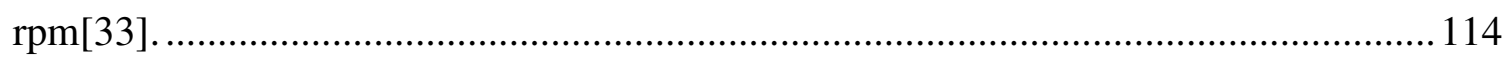

Gráfico 18 - Potência, avanço e mistura em \%, para uma rotação média de 6000 a 6500 rpm [33]. 114

Gráfico 19 - Curva de potência em diferentes proporções de etanol [33]............................ 115

Gráfico 20 - Ganho de potência médio [33].................................................................... 116

Gráfico 21 - Potência Máxima X proporção de Etanol[33].................................................. 116

Gráfico 22 - Potência X Rotação X Ângulo do pedal [33] .................................................... 117 
Gráfico 23 - Emissões de Poluentes HC e COc(média entre 900 e 2500 rpm) [33].

Gráfico 24 - Consumo do Daewoo Lanos[33]

Gráfico 25- Consumo dos combustíveis na cidade de São Paulo[33].................................. 121

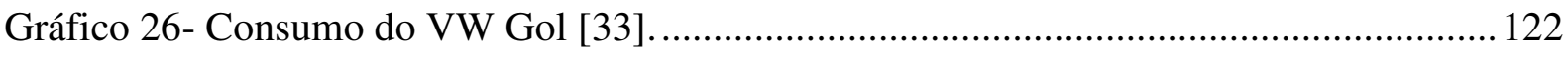

Gráfico 27 - Custo relativo com os combustíveis [33]..................................................... 123

Gráfico 28 - Custo mensal estimado com combustível [33]. ............................................. 123 


\section{LISTA DE TABELAS}

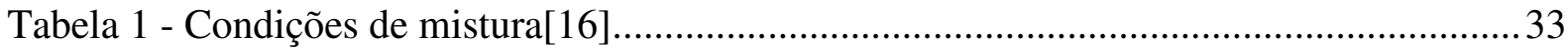

Tabela 2- Fontes e características dos principais poluentes na atmosfera[20].

Tabela 3- Limites máximos de emissão de $\mathrm{CO}$ e $\mathrm{HC}$ corrigidos. (resolução CONAMA n 07/93)[23].

Tabela 4 - Limites máximos de emissão de CO Corrigido, em marcha lenta e a $2500 \mathrm{rpm}$, para veículos com motor do ciclo Otto (Resolução CONAMA 418, 25/11/2009) [24]...38

Tabela 5 - Limites máximos de emissão de HC corrigido, em marcha lenta e a $2500 \mathrm{rpm}$ para veículos com motor do ciclo Otto. (Resolução CONAMA 418, 25/11/2009) [24]. ........ 38

Tabela 6 - Performance do veículo Corsa MultiPower com Gasolina , etanol e GNV [30]...49

Tabela 7 - Preço médio em reais dos combustíveis na cidade de São Paulo no ano de

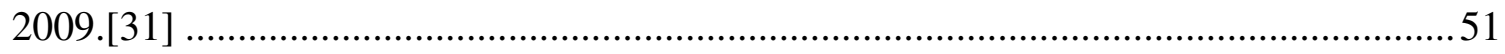

Tabela 8 - Preço médio praticado no Brasil em 2009[31] ......................................................52

Tabela 9 - Descrição do veículo de teste Daewoo Lanos.[32] ...............................................53

Tabela 10 - Descrição do veículo de teste VW Gol.[34].......................................................54

Tabela 11 - Materiais utilizados no sistema de GNV aspirado [33] ......................................55

Tabela 12 - Materiais utilizados no sistema de conversão com injeção positiva de GNV [33].

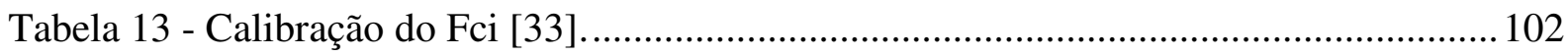

Tabela 14 - Comparação entre potências utilizando Etanol e GNV[33]. .............................. 103

Tabela 15 - Definição dos Estados de configuração de mistura de GNV e Etanol[33]. ........ 105

Tabela 16 - Configuração do Variador de Avanço[33] ........................................................... 106

Tabela 17 - Configurações de misturas de combustíveis e do variador de avanço[33].......... 106

Tabela 18 - Potência, avanço e mistura em \%, para uma rotação média de 2000 a 2500 rpm [33]

Tabela 19 - Potência, avanço e mistura em \%, para uma rotação média de 2500 a 3000 $\operatorname{rpm}[33]$. 109

Tabela 20 - Potência, avanço e mistura em \%, para uma rotação média de 3000 a 3500 rpm [33].

Tabela 21 - Potência, avanço e mistura em \%, para uma rotação média de 3500 a 4000 rpm [33]. 
Tabela 22 - Potência, avanço e mistura em \%, para uma rotação média de 4000 a 4500

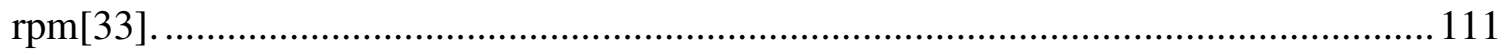

Tabela 23 - Potência, avanço e mistura em \%, para uma rotação média de 4500 a 5000

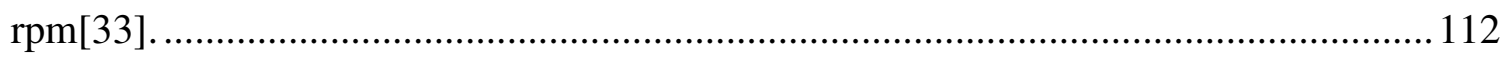

Tabela 24 - Potência, avanço e mistura em \%, para uma rotação média de 5000 a 5500 rpm [33]. 113

Tabela 25 - Potência, avanço e mistura em \%, para uma rotação média de 5500 a 6000 rpm [33]. 113

Tabela 26 - Potência, avanço e mistura em \%, para uma rotação média de 6000 a 6500 rpm [33]. 114

Tabela 27 - Consumo dos combustíveis no Daewoo Lanos [33]. 119

Tabela 28 - Consumo mensal em reais dos combustíveis na cidade de São Paulo[33]......... 120

Tabela 29 - Consumo dos combustíveis no VW Gol[33].

Tabela 30 - Comparativo financeiro entre o sistema de conversão aspirado e o protótipo

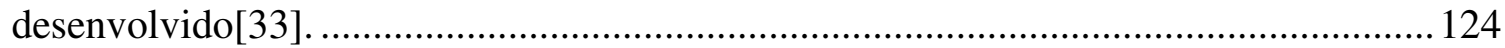

Tabela 31 - Preços dos sistemas de conversão em São Paulo[33]........................................ 134 


\section{LISTA DE ABREVIATURAS E SIGLAS}

A/D

ANP

CONAMA

DETRAN

DOU

E100

E23

FLEX

GLP

GM

GNC

GNL

GNV

IAD

INMETRO

IPVA

MAF

MAP

MTBE

NF

PMI

PMS

PROCONVE

rpm

UCE

VAF

VW
Analógico/Digital

Agência Nacional do Petróleo, Gás Natural e Biocombustíveis

Conselho Nacional do Meio Ambiente

Departamento Estadual de Transito

Diário Oficial da União

Etanol a $100 \%$

Gasolina com $23 \%$ de etanol etílico anidro

Bicombustível (Flexível)

Gás Liquefeito de Petróleo - gás de cozinha

General Motors

Gás natural comprimido

Gás Natural Liquefeito

Gás Natural Veicular

Índice Antidetonante

Instituto Nacional de Metrologia, Normalização e Qualidade Industrial

Imposto sobre Veículos Automotores.

Mass Airflow

manifold absolute pressure

Metil Terci-Butil Éter

Normalmente Fechado

Ponto Morto Inferior

Ponto Morto Superior

Programa de Controle Veícular

Rotações Por Minuto

Unidade de Controle Eletrônico ou módulo de injeção

Vane Airflow

Volkswagem 


\section{LISTA DE SÍMBOLOS}

$\mathrm{CO}$

$\mathrm{Co}_{\mathrm{c}}$

$\mathrm{CO}_{\text {medido }}$

$\mathrm{CO}_{2}$

$\mathrm{e}(\mathrm{t})$

Fat $_{\text {lambda }}$

Fce

$\mathrm{F}_{\text {diluição }}$

$F C_{g n v}$

$\mathrm{FCi}$

$F C_{\text {rpm }}$

$\mathrm{HC}$

$\mathrm{HCc}$

$\mathrm{HC}_{\text {medido }}$

$M G_{g n v}$

$M l_{\text {líqudio }}$

$\mathrm{NV}$

$\mathrm{r}(\mathrm{t})$

$\mathrm{s}(\mathrm{t})$

Tiggnv

Tif $f_{\text {líquido }}$

Ti $i_{\text {original }}$

$\mathrm{u}(\mathrm{t})$

y

$\mathrm{ZrO}_{2}$

$\lambda$

$\Phi$
Monóxido de Carbono

Monóxido de Carbono corrigido

Monóxido de Carbono medido

Dióxido de Carbono

Sinal de erro

Fator Lamda

Fator de correção do etanol

Fator de diluição

Fator de correção do GNV

Favor de correção da injeção ( GNV ou Etanol)

Fator de correção da rotação

Hidrocarboneto

Hidrocarboneto corrigido

Hidrocarboneto medido

Mistura de GNV, porcentagem da mistura de GNV

Mistura do combustível líquido, porcentagem da mistura.

Eficiência volumétrica

Sinal de referência

Saida

Tempo de injeção do GNV

Tempo de injeção final do combustível líquido

Tempo de injeção original

Sinal de controle

Relação entre o número de carbono e hidrogênio

Dióxido de Zirconio

Razão entre a mistura real e a mistura estequiométrica

Inverso de $\lambda$, razão entre a mistura estequiométrica e a mistura real 


\section{SUMÁRIO}

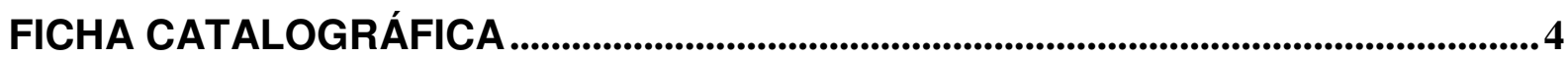

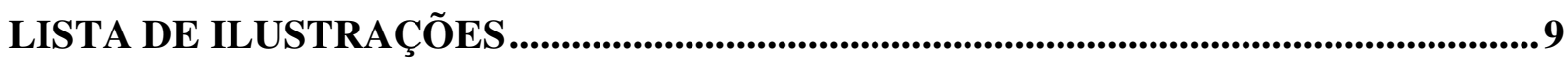

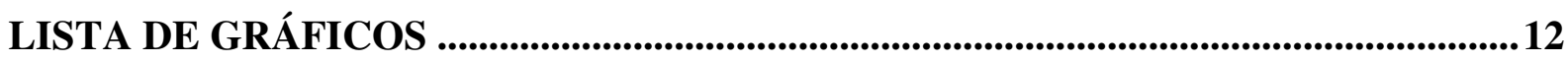

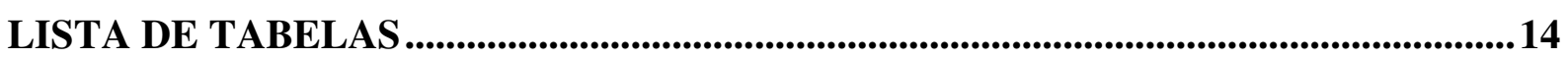

LISTA DE ABREVIATURAS E SIGLAS ...............................................................16

LISTA DE SÍMBOLOS ............................................................................................17

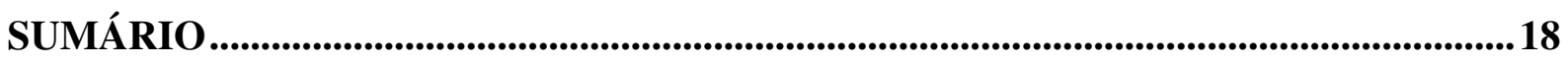

1 INTRODUÇÃO ..............................................................................................................21

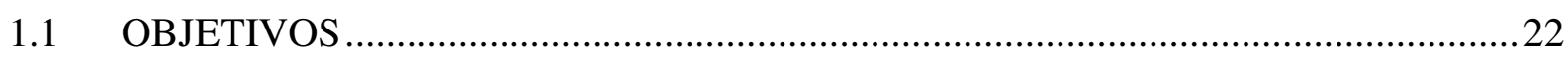

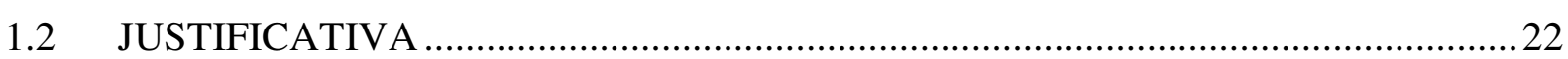

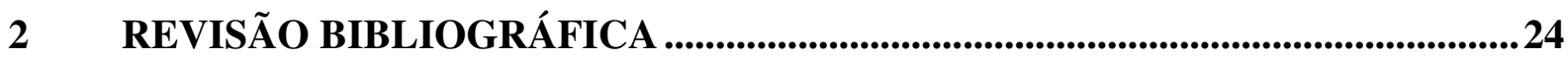

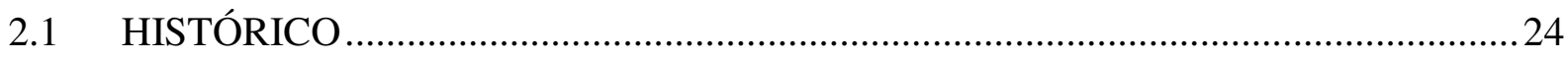

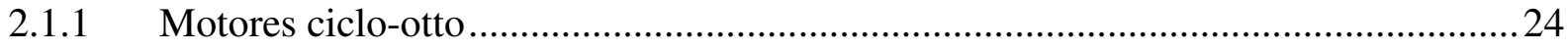

2.1.2 Origens do etanol como combustível..............................................................25

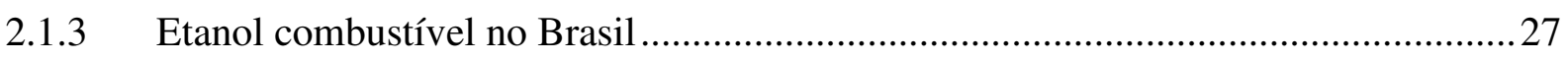

2.1.4 Uso do gás natural como combustível ………………………………………......29

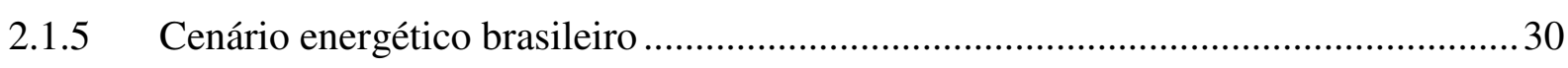

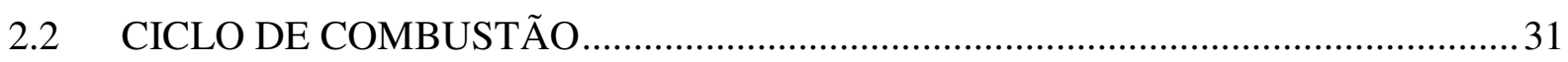

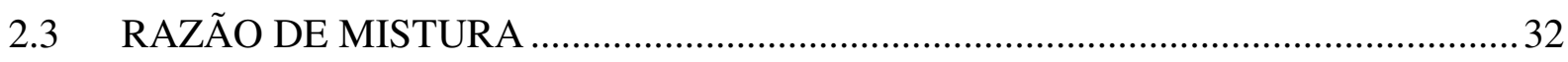

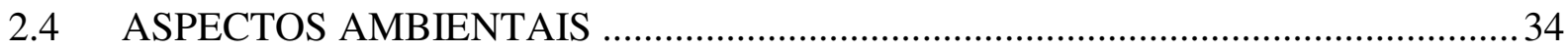

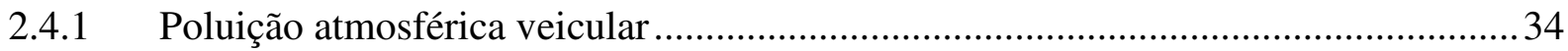

2.4.2 Efeitos gerais dos poluentes no meio ambiente …………………………………..... 35

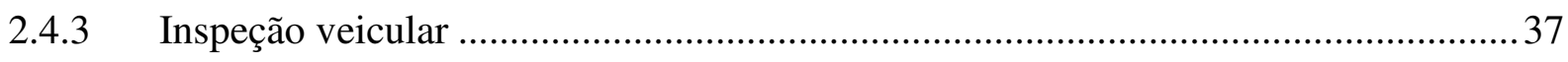

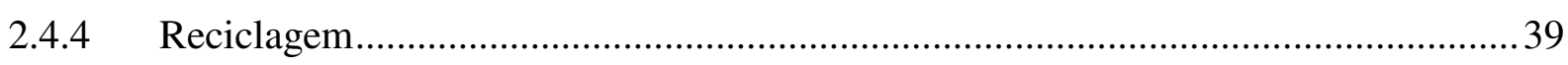

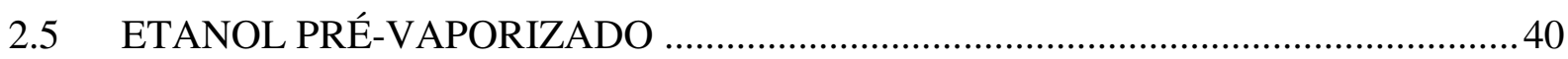

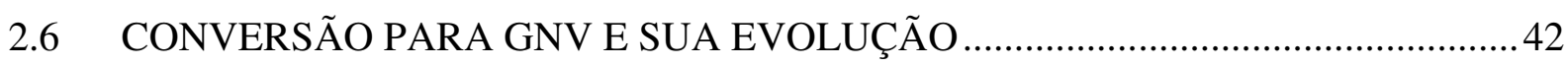

2.6.1 Primeira geração de conversores para GNV ………………………………………... 42

2.6.2 Segunda geração de conversores para GNV ………………………………….....4

2.6.3 Terceira geração de conversores para GNV …………………………………….....4

2.6.4 Quarta geração de conversores para GNV ............................................................. 45

2.6.5 Quinta geração de conversores para GNV ...............................................................46 


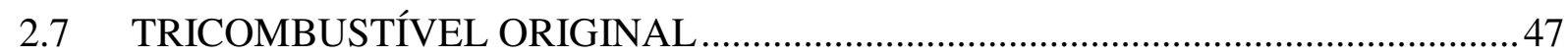

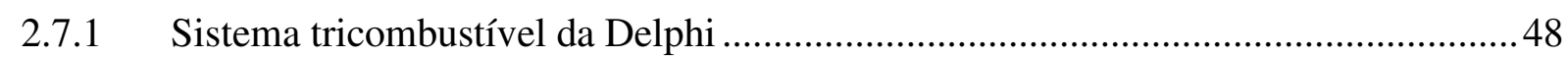

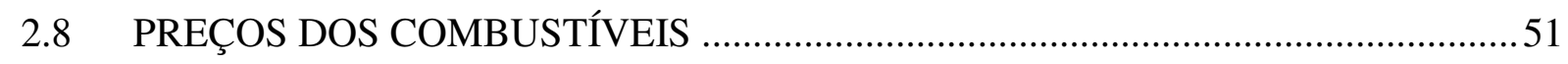

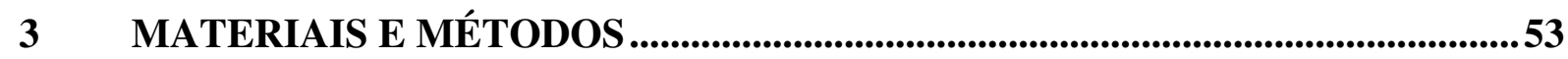

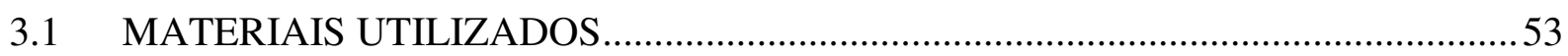

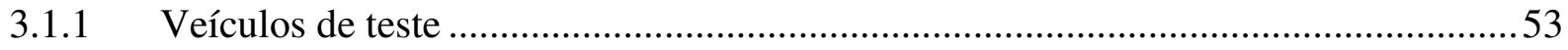

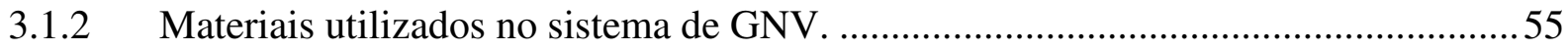

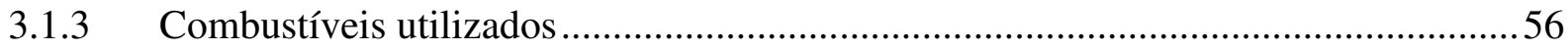

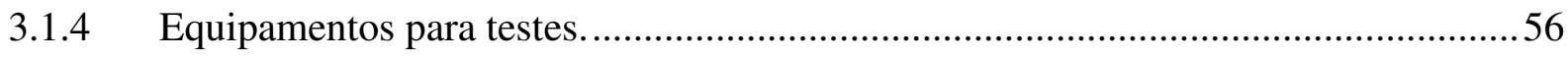

3.2 SISTEMA DE INJEÇÃO ELETRÔNICA DO PROTÓTIPO ....................................57

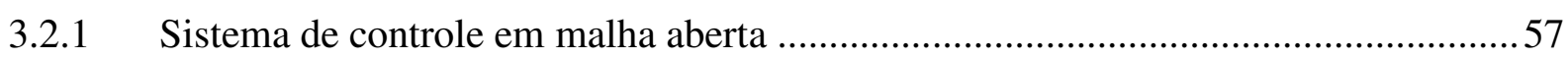

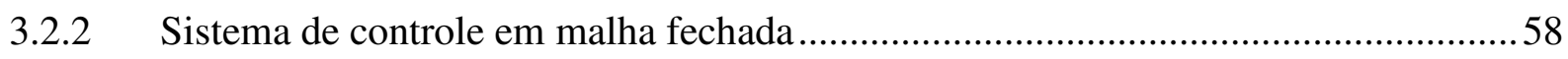

3.2.3 Sistema de controle em injeção eletrônica................................................................59

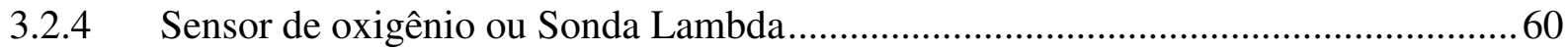

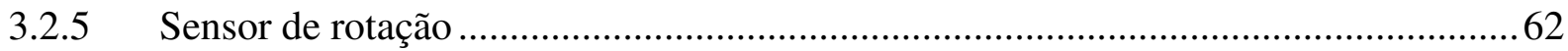

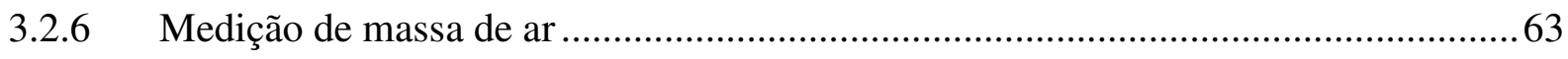

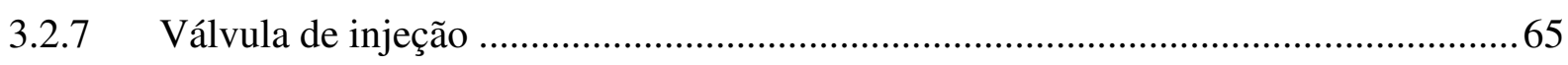

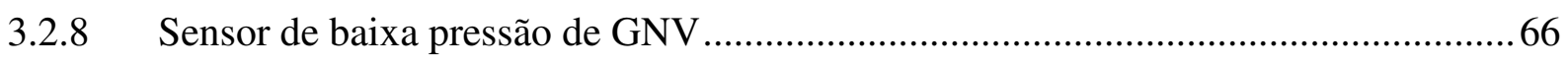

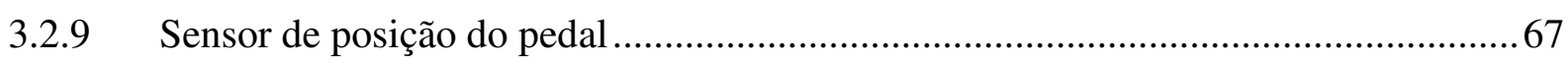

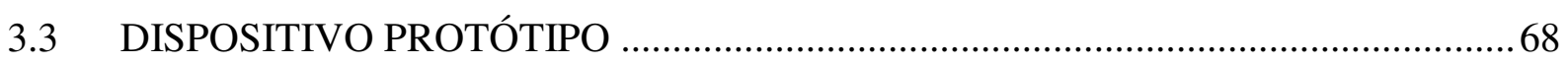

3.3.1 Circuito e leiaute do gerenciador tricombustível ..................................................... 72

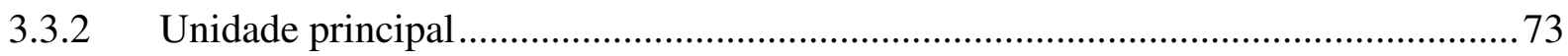

3.3.3 Sensor de oxigênio ou sonda lambda.................................................................. 75

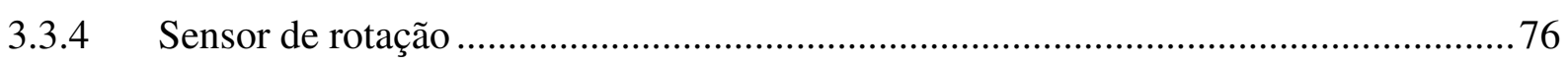

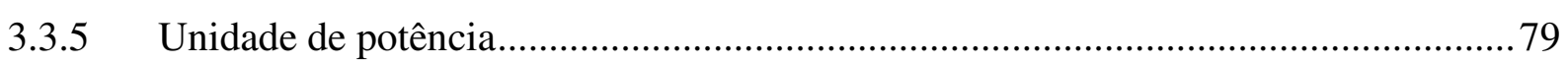

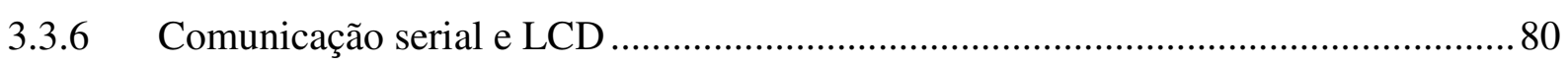

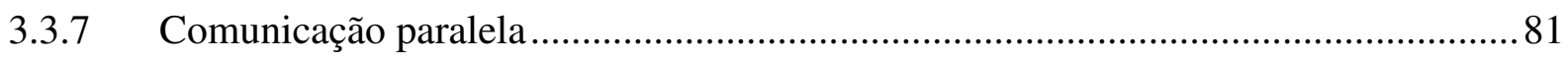

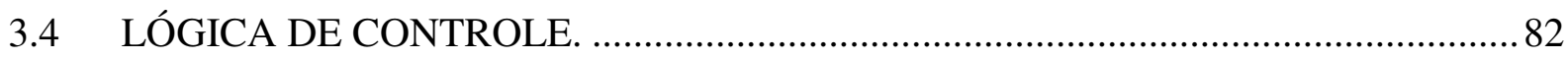

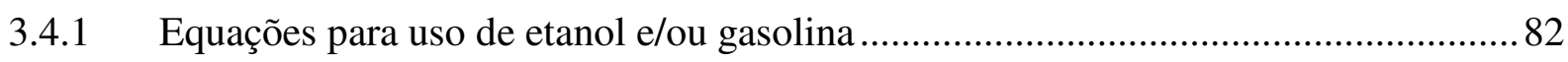

3.4.2 Equações para o uso exclusivo de GNV ............................................................... 84

3.4.3 Equações para o uso simultâneo de GNV e etanol e/ou gasolina............................... 85

3.5 INSTALAÇÃO DO SISTEMA DE GNV CONVENCIONAL POR ASPIRAÇÃO. .. 86

3.6 INJEÇÃO MULTIPONTO DE GNV UTILIZANDO AS VÁLVULAS INJETORAS

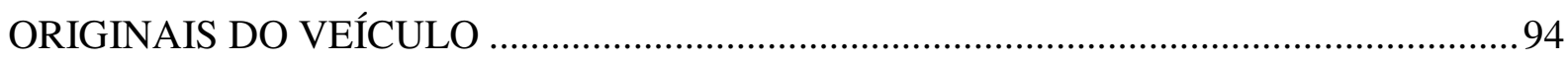




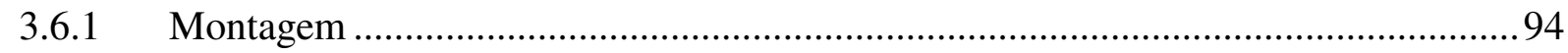

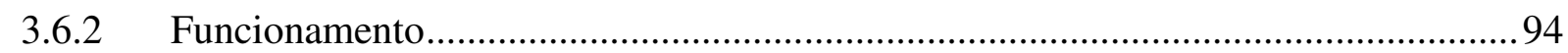

3.7 INSTALAÇÃO DO SISTEMA DE INJEÇÃO POSITIVA DE GNV ........................95

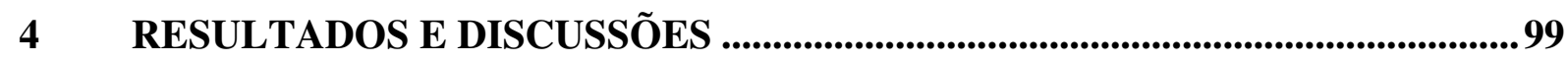

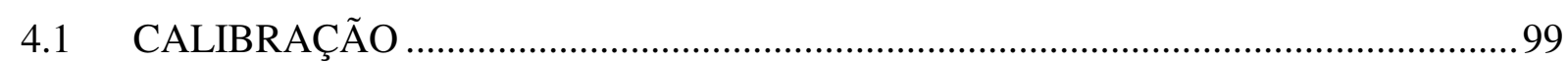

4.1.1 Calibração para uso do etanol no Daewoo Lanos ....................................................99

4.1.2 Calibração do Daewoo Lanos para uso do GNV no sistema de injeção positiva .... 100

4.1.3 Calibração do VW gol para uso do GNV ............................................................. 101

4.1.4 Calibração do VW Gol para uso do GNV e etanol simultâneo ................................ 105

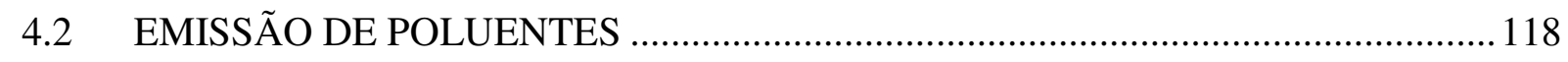

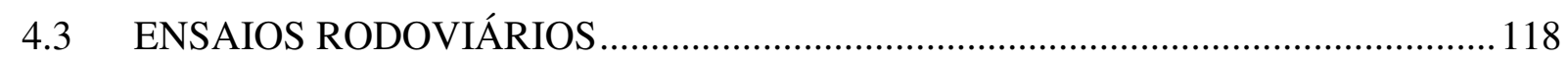

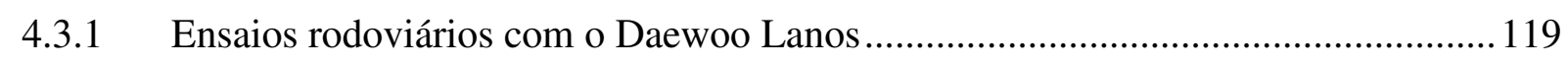

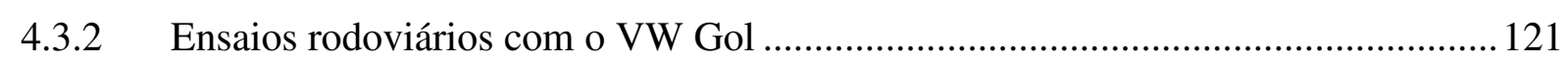

4.4 VIABILIDADE ECONÔMICA …........................................................................ 124

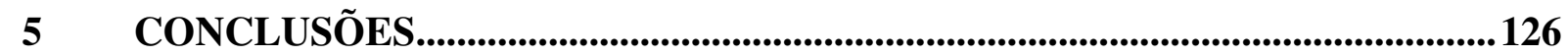

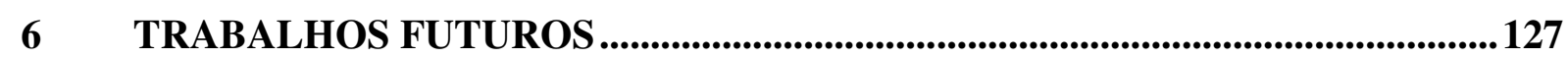

6.1 DESENVOLVIMENTO DE UM PROTÓTIPO DE UM SISTEMA

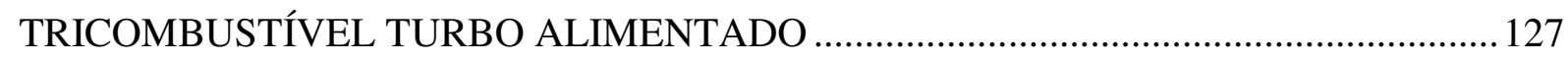

6.2 ESTUDO DO DESGASTE DE MOTORES CONVERTIDOS A GNV ................... 127

6.3 PROTÓTIPO DE UM SISTEMA DE INJEÇÃO DE ETANOL PRE-VAPORIZADO ..

6.4 ESTUDO SOBRE O COMPORTAMENTO DO VARIADOR DE AVANÇO EM

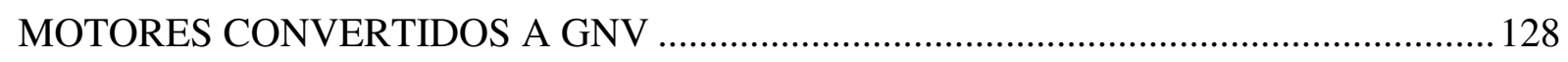

6.5 VÁLVULA INJETORA E REDUTOR DE PRESSÃO DE BAIXO CUSTO PARA

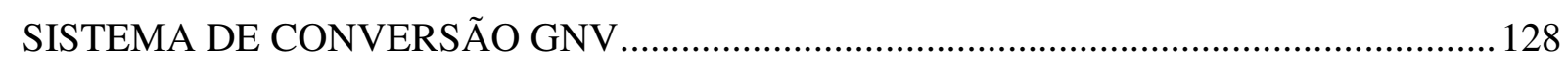

6.6 SISTEMA DE GNV ASPIRADO COM INJEÇÃO SIMULTÂNEA DE ETANOL OU

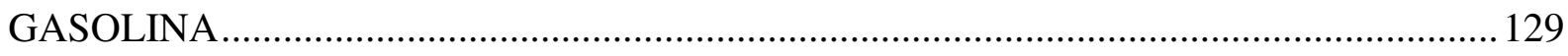

REFERÊNCIAS BIBLIOGRÁFICAS ....................................................................................... 130

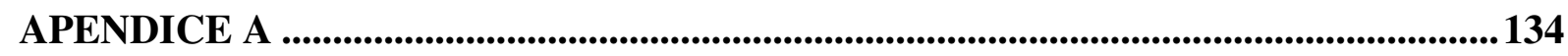

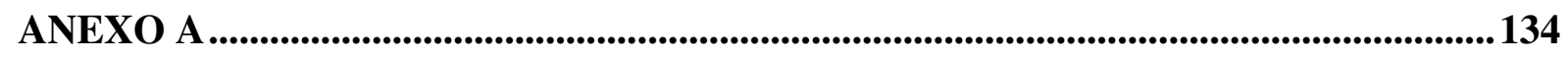

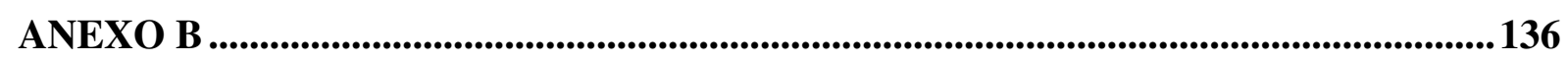




\section{INTRODUÇÃO}

Muito se investiu no desenvolvimento da tecnologia bicombustível e atualmente a maioria dos veículos vendidos no Brasil são bicombustíveis. Entre os autoveículos leves (automóveis e comerciais leves) licenciados em 2008, 87,2\% possuem motores bicombustíveis, seguido por $8,1 \%$ movidos a gasolina e 4,7\% movidos e diesel[1], sendo que os veículos a diesel correspondem apenas aos utilitários devido a restrições na legislação brasileira, que impedem a fabricação de automóveis a diesel.

A utilização de veículos bicombustível tornou-se comum após o lançamento do primeiro veículo bicombustível em 2003, o Gol Power 1.6 Total Flex [2]. A maioria dos veículos nacionais com injeção eletrônica, fabricados a partir de 1991, que não possuem a tecnologia bicombustível (etanol e gasolina) podem se beneficiar fazendo uma conversão alternativa utilizando módulos eletrônicos que controlam a injeção de combustível, permitindo o uso do etanol em veículos originais a gasolina.

Até o momento no Brasil, os únicos veículos originais que utilizam o gás natural veicular (GNV) é o Fiat Siena Tetrafuel, o Astra e o Corsa da GM (General Motors), que podem utilizar gasolina brasileira que tem etanol em sua mistura, gasolina pura fornecida em outros países, etanol e GNV. A Fiat nomeou seu motor como tetrafuel por considerar como quarto combustível a mistura de etanol e gasolina. Os modelos da GM são adquiridos somente sob encomenda.

Nos veículos convertidos a GNV e nos veículos originais tricombustível, a perda de potência só é compensada através da intervenção do motorista, que utiliza a seleção manual do combustível, desligando a injeção do GNV passando a utilizar somente o combustível líquido. No Fiat Siena, essa seleção é feita automaticamente, mas não prevê o uso simultâneo de GNV e etanol.

Consumidores que desejam utilizar GNV em seus veículos têm a opção da conversão utilizando sistemas eletrônicos disponíveis no mercado, que ainda são pouco eficientes, pois não utilizam controle eletrônico da vazão do combustível e controle da mistura arcombustível.

Este trabalho está dividido em 6 capítulos. Neste capítulo foram descritos os objetivos e justificativas do trabalho. No capítulo 2, é apresentada a revisão da literatura pertinente ao trabalho, o estado da arte da tecnologia, incluindo um histórico, ciclo de combustão e a 
descrição dos sistemas de conversão existentes. No capítulo 3, são descritos os procedimentos experimentais, desenvolvimento do hadware e software do protótipo e sua instalação nos veículos de teste. No capítulo 4, são apresentados os resultados obtidos, incluindo calibração, ensaios rodoviários, dinamométricos e análise de emissão de poluentes, finalizando com uma análise de viabilidade econômica. No capítulo 5, são apresentadas as principais conclusões do trabalho, seguidas pelo capítulo 6, onde são sugeridos trabalhos futuros que possam dar alternativas ou continuiade a este trabalho.

\subsection{OBJETIVOS}

O principal objetivo do trabalho é o desenvolvimento de um sistema de conversão tricombustível para veículos originais a gasolina ou bicombustível, capaz de gerenciar automaticamente a relação de potência e ecônomia, proporcionando flexibilidade no abastecimento, com o uso de três combustíveis (GNV, etanol ou gasolina) e flexibilidade na potência através do uso simultâneo de (GNV) e etanol.

O sistema deve calcular automaticamente a prioridade de potência e economia através da solicitação de potência dada pelo ângulo do pedal do acelerador, minimizando uma das principais desvantagens do uso do GNV, que é a perda de potência, Isto garante máxima economia, com o uso do GNV sempre que a potência não for solicitada e utilizando GNV e o combustível líquido simultaneamente sempre que a potência for requerida.

\subsection{JUSTIFICATIVA}

As altas oscilações no mercado de combustíveis, que sofrem instabilidade de preço e incerteza de disponibilidade, influenciada por razões políticas, econômicas e naturais, tornaram necessário o desenvolvimento de veículos bicombustível, possibilitando o uso do combustível disponível que ofereça melhor relação custo-benefício.

No Brasil, a maioria dos veículos novos são bicombustíveis, utilizam etanol e gasolina. Entretanto, a fabricação de veículos tricombustível que utilizam etanol, gasolina e GNV ainda são restritas a apenas apenas três modelos: o Fiat Siena Tetrafuel, o Astra e o Corsa da 
General Motors (GM). Isto obriga o consumidor a buscar pela conversão de motores com sistemas que nem sempre otimizam o uso do GNV.

Os sistemas de conversão convencionais, embora não possuam controle eletrônico da mistura ar-combustível, proporcionam vantagens economicas. Todavia, pesquisas que visam o desenvolvimento de sistemas de injeção de GNV eficientes são necessárias para aumentar a vantagem econômica e minimizar a perda de potência.

Buscando atender o desejo do consumidor de uma relação custo-benefício que se adapta aos padrões de condução do motorista, o projeto busca aliar a flexibilidade de abastecimento, disponível nos sistema atuais, com a flexibilidade da potência através do uso simultâneo do GNV e do combustível líquido. 


\section{REVISÃO BIBLIOGRÁFICA}

Neste capítulo, são apresentados um histórico do uso do GNV, desde o desenvolvimento do primeiro motor, a origem dos combustíveis e seu uso no Brasil. São apresentados detalhes do ciclo de combustão e razão da mistura incluindo alguns aspectos ambientais. São descritos os sistemas de conversão para GNV existentes e o sistema tricombustível original, suas vantagens e desvantangens. Por fim, o levantamento dos preços médios dos combustíveis em 2009.

\subsection{HISTÓRICO}

Nesse capítulo é apresentado um breve histórico iniciando pelo desenvolvimento do primeiro motor ciclo-otto, a origem dos combustíveis e suas oscilações de preços ao longo da história.

\subsubsection{Motores ciclo-otto}

Em 1876, ocorre a verdadeira revolução nos transportes, quando o engenheiro alemão Nikolaus August Otto (1832 - 1891) desenvolveu o motor de combustão interna de 4 tempos, conhecido como ciclo Otto. Esse mesmo princípio é ainda utilizado pela grande maioria dos veículos. Otto teve seu trabalho financiado por Eugen Langen, proprietário de uma usina refinadora de açúcar, que provavelmente tinha ligações com os mercados de etanol da Europa [3].

A companhia Otto \& Langen obteve sucesso no ano de 1870 produzindo máquinas estacionárias principalmente a gás. O motor ciclo-otto, posteriormente desenvolvido, era abastecido principalmente com gasolina, sendo adaptável ao etanol ou ao benzeno de carvão.[3].

No motor ciclo-otto, a mistura ar-combustível é aspirada e comprimida no cilindro. No final da compressão, a vela provoca a combustão. Dessa forma, é importante que a vela provoque a combustão no momento ideal e que esta não ocorra espontaneamente devido à compressão. 
Nos motores de geração pré-alcool, a taxa de compressão ficava em torno de 7:1, isto é, a mistura era comprimida a 1/7 do seu volume primitivo. Atualmente, os motores flex possuem taxas maiores, por exemplo o Gol GIV Flex possui taxa de compressão de 13/1.

Um dos problemas da gasolina é sua baixa octanagem. Octanagem é a resistência que a gasolina tem a auto-ignição (detonação). Uma solução para aumentar a octanagem é a adição de um antidetonante, onde inicialmente foi utilizado o chumbo-tetraetila, que é um derivado do petróleo altamente poluente. Posteriormente, muitos países preocupados com questões ambientais optaram pela substituição por MTBE (Metil Terci-Butil Éter), menos poluente que o chumbo.

O Brasil foi o primeiro país a ficar livre do chumbo tetraetila, utilizando como antidetonante o etanol anidro, conforme determina a lei n. 8723, de 1993. O Rio Grande do Sul, que não produzia etanol, utilizou o MTBE na proporção de 15\% até 1999. [3]

Segundo as normas da Agência Nacional de Petróleo, Gás Natural e Biocombustíveis (ANP) no Brasil, esse número é dado pelo IAD (índice antidetonante). A ANP estabelece o IAD de 87 para gasolina comum e 91 para gasolina Premium[4], o etanol tem o IAD equivalente a 110 octanas, e o GNV tem seu índice de 115 a 130[5], o que garante taxas de compressão maiores.

\subsubsection{Origens do etanol como combustível}

Etanol combustível, ou Álcool etílico, definição: líquido incolor, volátil, com cheiro e sabor típicos, obtido por fermentação de substâncias açucaradas ou amiláceas, ou por processos sintéticos [6].

Segundo o escritor Alexander King apud[3], a fermentação de açúcares para produzir o etanol foi uma das primeiras invenções do homem, simultaneamente à moldagem das primeiras ferramentas. Técnicas de produção de etanol foram encontradas na cultura de vários povos antigos, chineses, egípcios, gregos, inclusive os indianos que já faziam preparados de cana-de-açúcar.

Desde o final de 1800, os cientistas já acreditavam na possibilidade do uso do etanol como combustível[3]. Em 1826, Samuel Morey usou o etanol disponível no mercado para fazer funcionar o primeiro protótipo americano com um motor de combustão interna. Porém, 
devido à falta de recursos somados ao entusiasmo com as máquinas a vapor não foi dada continuidade a sua pesquisa [3].

Em 1876, Nikolaus August Otto cria o motor de combustão interna de 4 tempos que funcionada com gasolina, etanol e gás. A maioria dos motores atuais utilizam o mesmo principio criado por Otto.

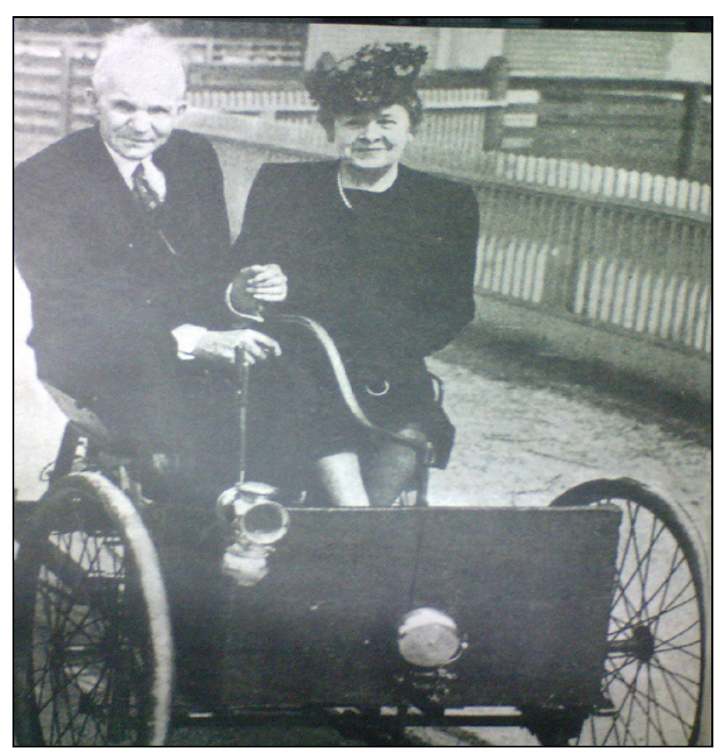

Figura 1 - Primeiro carro produzido por Henry Ford [3].

Na Figura 1, Henry Ford posa para foto no primeiro automóvel que desenvolveu em 1896, que podia utilizar tanto o etanol quanto a gasolina com combustível, ou seja, o primeiro carro produzido por Henry Ford já era bicombustível.

Embora as técnicas de produção de etanol e mesmo as de extração do petróleo passariam por uma evolução, o setor petroleiro tinha grande poder econômico e sua influência já era grande em todo mundo. Veículos movidos a etanol foram desenvolvidos ao longo da história, mas o uso da gasolina foi predominante, muito provavelmente devido às pressões do setor petroleiro.

A corrida por alternativas ao petróleo só ocorreu em momentos onde guerras prejudicavam sua produção, causando crises temporárias. Com o fim das crises, a disponibilidade da gasolina aumentava, seguida pela redução no seu preço, o que não tornava atrativos investimentos no etanol, pois o retorno seria incerto e a longo prazo. Mesmo em períodos desfavoráveis, não faltaram incentivadores à produção e desenvolvimento de tecnologia de produção do etanol. Um deles foi Henry Ford, que afirmou no inicio do século XX que " $O$ etanol é o combustível do futuro"[3] . 


\subsubsection{Etanol combustível no Brasil}

A produção de etanol no Brasil se beneficiou da experiência na produção da cana-de-açúcar, produzida desde seu descobrimento, possuindo uma agroindústria canavieira implantada e difundida no país[3].

No final do século XIX, incentivos do governo imperial garantiram uma modernização da industria açucareira. Como tentativas de melhorar o seu rendimento, foram feitos investimentos na infra-estrutura com modernas usinas, estradas de ferro e substituição da tração animal por maquinas a vapor.

Durante o governo de Washington Luiz Pereira de Souza (1926 - 1930), não houve evolução da industria alcooleira brasileira. Washington Luiz teria incentivando a abertura de novas estradas, em detrimento de vias férreas, atendendo aos interesses das ricas distribuidoras de gasolina e lubrificantes, que queriam incentivar o transporte rodoviário no Brasil para venderem mais seus produtos[3].

Até 1930, a produção de etanol era apenas um subproduto da cana-de-açúcar com a destilação do mel residual. Uma profunda mudança na política de incentivos começou com Getúlio Vargas, assumindo o governo quando o setor estava em uma profunda crise, com superprodução e baixa nos preços.

Poucos meses depois de assumir a presidência, Getúlio determinou créditos especiais para montagem de bombas para fornecimento e aquisição de frota para transporte do produto, criou decretos para obrigar a proporção de 5\% de etanol na gasolina e isentou os impostos e taxas de importação para materiais necessários à usina[3] .

Em junho de 1933, foi criado o Instituto do Açúcar e do Álcool, vinculado ao ministério da agricultura, com o objetivo de assegurar o equilíbrio do mercado do açúcar e aproveitar as possibilidades, cada vez maiores, oferecidas ao consumo do etanol industrial [3].

Com uma infra-estrutura já instalada, o uso do etanol teve sua ascensão na segunda guerra mundial, quando a importação de gasolina ficou extremamente prejudicada. Sua escassez fez com que a proporção de etanol na gasolina chega-se a 62\% no período de 1942 a 1946. Após esse período, a importação de gasolina volta ao normal, seguida de uma queda nos preços, interrompendo incentivos e investimentos na produção do etanol.

Durante os anos de 1950 e 1960, ocorreu uma grande expansão petrolífera, reduzindo drasticamente o preço do barril do petróleo, chegando a 1,88 dólares por barril em 1965.

Com o choque no petróleo, em 1973, os investimentos se voltam novamente ao etanol, com 
criação do Pró-Alcool, em 1974, que foi reforçado com a nova crise do petróleo, em 1980. Isto aumentou a procura por veículos movidos a etanol, fazendo com que, em 1983, 90\% dos veículos novos vendidos fossem movidos a etanol.

Em 1989, o preço da gasolina se equipara ao do etanol, provocando grande decepção aos proprietários de veículos a etanol. Este problema só seria resolvido em 2003, com o lançamento dos veículos bicombustíveis, tornando essa flexibilidade fundamental nesse cenário onde a variação de preços é imprevisível.

Em 2005, é lançado o programa nacional do Biodiesel que, aliado ao etanol, torna o País mais uma vez pioneiro na substituição dos combustíveis fósseis. Em abril de 2008, o consumo do etanol passa a ser superior ao da gasolina.

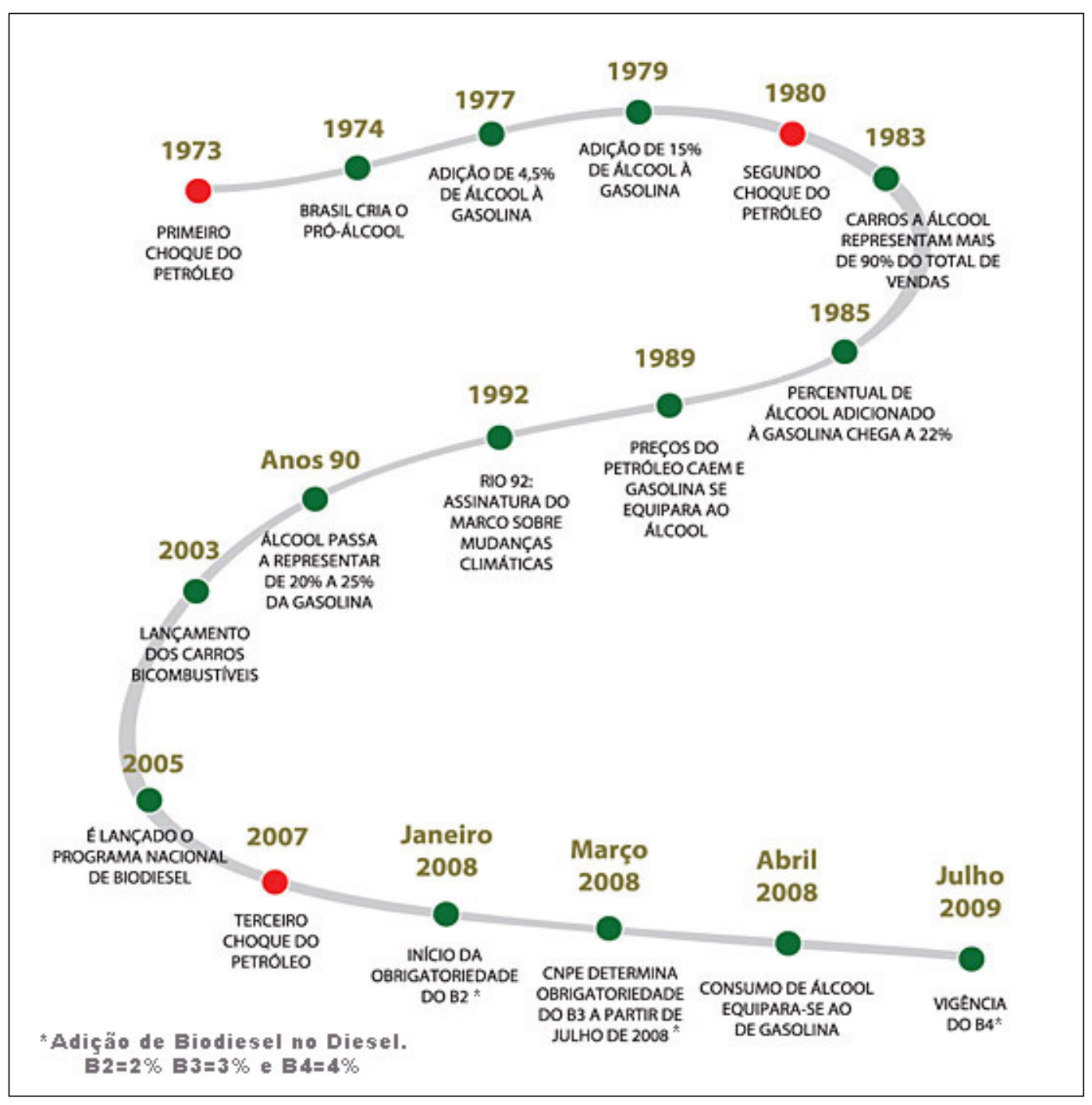

Figura 2 - A evolução dos combustíveis no Brasil[7]. 
Na Figura 2, é apresentada uma linha de tempo com a evolução dos combustíveis no Brasil, destacada em vermelho, por três principais choques do petróleo.

Para padronizar a nomenclatura brasileira com a utilizada no mercado internacional, a ANP publicou no DOU (Diário oficial da União), em 02/04/2009, a resolução que autoriza a utilização do termo etanol, até então pouco usado no Brasil [8].

\subsubsection{Uso do gás natural como combustível}

A utilização do gás como combustível vem do próprio invento do motor de combustão interna, uma vez que os primeiros motores ciclo-otto utilizavam gás natural.

A comercialização e distribuição do GNV no Brasil depende, em sua maioria, de gasodutos. Localidades que não possuem gasodutos podem ser abastecidas por carretas de GNC (Gás natural comprimido), sendo uma alternativa viável somente para distâncias de até $150 \mathrm{~km}$ de uma unidade de compressão[9].

O GNV é um combustível de difícil adulteração. As análises de qualidade são feitas antes de sua distribuição, seguindo a resolução ANP $\mathrm{n}^{\circ}$ 16, de 17.6.2008[10], que estabelece a especificação do gás natural, de origem nacional ou importada, a ser comercializado.

O inciso III, artigo 14, da Portaria ANP $n^{\circ} 32$, de 06 de março de 2001, estabelece que o revendedor varejista de GNV obriga-se a disponibilizar GNV ao consumidor final a pressão máxima de abastecimento de $220 \mathrm{Kgf} / \mathrm{cm}^{2}$, equivalente a 215,7 bar, 21,57 $\mathrm{MPa}$ ou 3129,14 psi[11]. O abastecimento com pressão superior a $220 \mathrm{kgf} / \mathrm{cm}^{2}$ pode causar redução da vida útil do cilindro e do restante dos componentes do kit de conversão.

A grande maioria dos acidentes em postos de GNV é causada pela má instalação ou instalação clandestina de kits de conversão. Os acidentes são provocados devido à instalação de válvulas e cilindros não homologados, principalmente com o uso de cilindros de GLP (Gás Liquefeito de Petróleo) ou de gás freon, que não resistem à pressão fixada pela ANP.

Acidentes ocorridos com veículos movidos a GNV também são provocados por falta de manutenção no sistema de combustível líquido, pois seus defeitos não resultam em mau funcionamento do veículo, uma vez que o GNV está sendo usado a maior parte do tempo. Essa falta de manutenção facilita o ressecamento de mangueiras e aumenta a possibilidade de vazamentos, aumentando o risco de incêndio. 
O GNV disponível no Brasil é exclusivamente de origem fóssil. Contudo, pode ser obtido de fontes renováveis, principalmente do lixo de dejetos sanitários, gerando o Biogás. Quimicamente, o Biogás é igual ao GNV de origem fóssil, podendo substituí-lo sem a necessidade de alterações nos veículos [12][13] .

A Petrobras negocia parcerias com empresas de limpeza urbana e saneamento em todo Brasil para aproveitar o Biogás na geração de energia elétrica [7].

Na Europa, principalmente na Suécia há postos de biogás gerados através de dejetos sanitários[13]. No futuro, o Brasil também pode ter o GNV de origem renovável.

\subsubsection{Cenário energético brasileiro}

O Brasil é beneficiado por não depender de uma única fonte energética, sendo que a maior parte da energia elétrica vem das hidroelétricas. O transporte de carga e o trasporte coletivo é movido principalmente pelo Diesel, e devido à legislação brasileira, que impede o uso de veículo leves a diesel, os veículos leves são movidos a etanol, gasolina ou GNV.

O Brasil é auto-suficiente na produção do petróleo. Sua valorização nos últimos anos justificou o investimento na exploração em poços mais profundos, tornando o Brasil um possível exportador, devido à disponibilidade de extração em novos poços encontrados abaixo da camada pré-sal.

Na produção de etanol, o Brasil é pioneiro a partir da cana de açúcar, com grande potencial de expansão dessa cultura, sem que ocorra prejuízo à produção de alimentos.

Em relação ao GNV, há uma previsão de grande expansão. A Petrobras pretende investir cerca de US\$10 bilhões até 2015, incluindo a implantação de 9 mil quilômetros de dutos e gasodutos, novos terminais, inclusive de GNL (Gás Natural Liquefeito), sendo prevista uma ampliação de sua infra-estrutura de transporte em cerca de dois terços [14].

A corrida para instalar mais gasodutos se explica pela expectativa do aumento da produção do gás natural, além da possibilidade de aproveitar parte da produção atual que é re-injetada nos campos, ou mesmo queimada, muitas vezes por falta de infraestrutura de escoamento[14].

Segundo Paulo Roberto Costa, diretor de abastecimento da Petrobras, os investimentos em dutos está sendo considerado sob o horizonte de 2030, sendo que toda a parte de terminais e dutos está sendo pensada no crescimento da demanda em derivados de petróleo e etanol, 
considerando também que o Brasil pode transformar-se em exportador de gás devido à possibilidade de oferta futura [14].

Um dos problemas dos consumidores do GNV é que o combustível também é utilizado no setor industrial, sendo que para estes grandes consumidores as distribuidoras preveem contratos de compensações caso o combustível venha a faltar.

Muitos consumidores industriais possuem tecnologia flexível. As distribuidoras têm contrato para fornecer o combustível alternativo, gasolina ou etanol pelo preço compatível com o contratado para o gás. Já o consumidor do GNV não tem essas compensações, sendo que, na falta deste, são obrigados a pagar mais caro pelo etanol ou pela gasolina, conforme afirma Graça Silva Foster, diretora de Gás e Energia da distribuidora Bahiagas: "O consumidor de GNV não pode ser flexível, porque, no caso de falta do gás, ele teria de pagar pela gasolina o mesmo preço, e isso não vai acontecer" [14].

\subsection{CICLO DE COMBUSTÃO}

O ciclo de combustão do motor ciclo-otto é formado por 4 fases ou 4 tempos, iniciando o ciclo no ponto morto superior (PMS). Na Figura 3, são apresentados os 4 tempos de um motor ciclo-Otto.

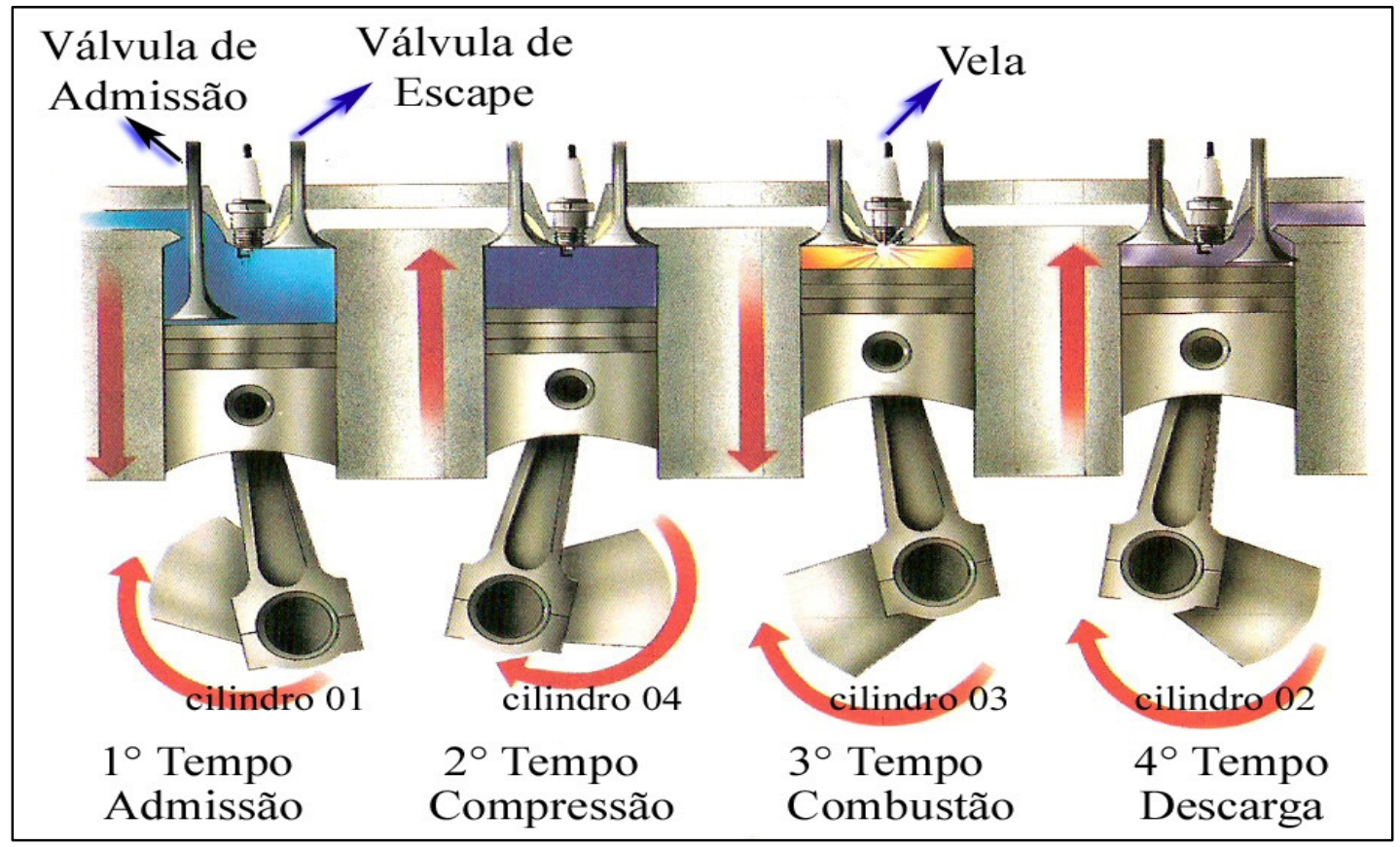

Figura 3 - Ciclo Otto - 4 tempos[15]. 
$1^{\circ}$ Tempo: A admissão ocorre quando o pistão está no (PMS) e afasta-se do cabeçote, criando uma depressão que provoca a aspiração da mistura ar-combustível chegando, ao ponto morto inferior (PMI). Nesse momento a válvula de admissão está aberta e a de escape fechada.

$2^{\circ}$ Tempo - Compressão: A válvula de admissão é fechada e a válvula de escape se mantém fechada, iniciando a subida do cilindro, comprimindo a mistura ar-combustível até alcançar o PMS.

$3^{\circ}$ Tempo - Combustão e expansão: A combustão é iniciada antes do final do $2^{\circ}$ tempo, antes do pistão atingir o PMS. A combustão da mistura ar-combustível eleva a temperatura e a pressão, que desloca o cilindro do PMS ao PMI, transmitindo deste modo ao eixo de manivelas à força motriz favorável a rotação [16].

$4^{\circ}$ Tempo - Descarga: Antes de o cilindro atingir o PMI no final do $3^{\circ}$ tempo, a válvula de escape começa a abrir-se, liberando os gases queimados para o exterior do cilindro até a chegada ao PMS, quando a válvula de escape é fechada para que a válvula de admissão seja aberta, retornando ao $1^{\circ}$ tempo.

\subsection{RAZÃO DE MISTURA}

Os sistemas de injeção buscam o balancemento da razão da mistura ar-combustível, conhecida como mistura estequiométrica, que depende do balanço de massa do hidrocarboneto contido no combustível e o ar. Se o oxigênio disponível for suficiente, o combustível hidrocarboneto pode ser completamente oxidado [16] .

Em geral, a combustão em motores realiza-se a partir do ar atmosférico que apresenta, para cada mol de oxigênio, 3.773 moles de nitrogênio[16]. Independente do combustível utilizado, etanol, gasolina ou GNV, o processo de combustão completo de um hidrocarboneto de composição molecular $\mathrm{C}_{\mathrm{a}} \mathrm{H}_{\mathrm{b}}$ com o ar, é dada pela eq.(1)[17].

$$
\left(C_{a} H_{b}\right)+\left(a+\frac{b}{4}\right)\left(O_{2}+3,773 N_{2}\right)=a C O_{2}+\frac{b}{2} H_{2} O+3,773\left(a+\frac{b}{4}\right) N_{2}
$$

Reescrevendo a eq.(1) utilizando os pesos molares do oxigênio, nitrogênio, carbono atômico e hidrogênio respectivamente como 31.998, 28.16, 12.001 e 1.008, obtêm a eq.(2) dependendo somente da composição do hidrocarboneto $\mathrm{CH}_{\mathrm{y}}$, onde A é a massa de ar e $\mathrm{C}$ é a massa de 
combustível, $s$ representa a condição estequiométrica e $y$ a relação entre o número de carbono e hidrogênio do combustível ( $y=\mathrm{b} / \mathrm{a})$ [16] .

$$
\left(\frac{A}{C}\right)_{s}=\frac{\text { massa de ar }}{\text { massa de combustível }}=\frac{\left(1+\frac{Y}{4}\right)(32+3,773(28,16))}{12,011+1,088}=\frac{34,56(4+y)}{12,011+1,008}
$$

A eq.(2) representa a mistura estequiométrica. $O$ fator lambda $(\lambda)$ representa a razão entre a mistura real e a mistura estequiométrica, e o parâmetro fi $(\phi)$ representa o inverso de $\lambda$, como mostra a eq.(3).

$$
\lambda=\phi^{-1}=\frac{\left(\frac{A}{C}\right)_{r e a l}}{\left(\frac{A}{C}\right)_{s}}
$$

Quando a mistura possui excesso de oxigênio, ela é pobre, e quando está com excesso de combustível, ela é rica. Quando o oxigênio está ideal, ela é estequiométrica, conforme apresentado na Tabela 1.

Tabela 1 - Condições de mistura[16].

\begin{tabular}{ccc}
\hline Mistura & $\boldsymbol{\lambda}$ & $\boldsymbol{\phi}$ \\
\hline Rica & $<1$ & $>1$ \\
Pobre & $>1$ & $<1$ \\
Estequiométrica & $=1$ & $=1$ \\
\hline
\end{tabular}

A obtenção do fator lambda é um importante parâmetro para que o sistema de injeção altere a quantidade de combustível a ser injetada, proporcionando a correção da mistura arcombustível. As equações referentes à razão da mistura de combustível não são utilizadas pelo sistema de injeção. $O$ fator $\lambda$ não é calculado através da eq.(3), seu valor é obtido através da leitura do sensor conhecido como sonda lambda, ou sensor de oxigênio.

A sonda lambda, instalada no escapamento, gera uma tensão inversamente proporcional à quantidade de oxigênio nos gases de escape. Independente do combustível utilizado, o sistema 
de injeção analisa a estequiometria da mistura (rica, pobre ou estequiométrica), determinando a quantidade de combustível a ser injetada.

A mistura estequiométrica não é importante apenas para economia de combustível, mas também pela redução nas emissões de poluentes, como o monóxido de carbono (CO) e os hidrocarbonetos (HC).

\subsection{ASPECTOS AMBIENTAIS}

Nesse capítulo são descritos alguns aspectos ambientais, incluindo a poluição veícular, seus efeitos, e as medidas para minimizá-los, através de programas de inspeção veicular e reciclagem.

\subsubsection{Poluição atmosférica veicular}

A poluição atmosférica nas áreas metropolitanas são geradas principalmente pelos veículos automotores. No Brasil, durante as décadas de 60 e 70, as indústrias eram as principais fontes geradoras. Esse quadro se alterou após 1976, com a criação de leis que forçavam medidas de controle ambiental nas industrias, tornando o setor de transportes o principal poluidor, influenciado pelo aumento da frota de veículos e da população [18].

Com o aumento da concientização ambiental, muitos países começaram a se preocupar com a emissão de poluentes, criando leis de forma a reduzir essas emissões. Seguindo uma tendência internacional, o Brasil começou a redução na emissão de poluentes com a implantação do PROCONVE (Programa de Controle da Poluição do Ar por Veículos Automotores) em 1986, reduzindo a emissão de poluentes de veículos novos em cerca de $97 \%$ por meio de limitação progressiva da emissão, obrigando os fabricantes de automóveis a investir em tecnologias como a injeção eletrônica de combustível e o catalisador [19] . 


\subsubsection{Efeitos gerais dos poluentes no meio ambiente}

Na Tabela 2 tem-se os principais poluentes na atmosfera, sendo que estes, exceto o ozônio têm como fonte principal os veículos automores.

O controle correto da combustão e o uso de catalizadores diminui a emissão dos gases mostrados na Tabela 2, mas não é possível evitar a emissão de $\mathrm{CO}_{2}$, mesmo que o processo de combustão seja ideal e todos os gases nocivos sejam filtrados ou convertidos em gases menos nocivos.

Tabela 2- Fontes e características dos principais poluentes na atmosfera[20].

\begin{tabular}{|c|c|c|c|}
\hline POLUENTE & CARACTERISTICAS & FONTES PRINCIPAIS & $\begin{array}{l}\text { EFEITOS GERAIS AO MEIO } \\
\text { AMBIENTE }\end{array}$ \\
\hline $\begin{array}{l}\text { Partículas Inaláveis } \\
\left(\mathrm{MP}_{10}\right) \text { e Fumaça }\end{array}$ & $\begin{array}{l}\text { Particulas de material sólido ou liquido que } \\
\text { ficam suspensos no ar, na forma de poeira, } \\
\text { neblina, aerossol, fumaça, fuligem, etc. Faixa } \\
\text { de tamanho < } 10 \text { micra. }\end{array}$ & $\begin{array}{l}\text { Processos de combustão (indústria e veículos } \\
\text { automotores), aerossol secundário (formado } \\
\text { na atmosfera). }\end{array}$ & $\begin{array}{l}\text { Danos à vegetação, deterioraçẫo } \\
\text { da visibilidade e contaminaçẫo } \\
\text { do solo. }\end{array}$ \\
\hline $\begin{array}{l}\text { Particulas Totais em } \\
\text { Suspensão (PTS) }\end{array}$ & $\begin{array}{l}\text { Particulas de material sólido ou liquido que } \\
\text { ficam suspensos no ar, na forma de poeira, } \\
\text { neblina, aerossol, fumaça, fuligem, etc. Faixa } \\
\text { de tamanho < } 100 \text { micra. }\end{array}$ & $\begin{array}{l}\text { Processos industriais, veiculos motorizados } \\
\text { (exaustâo), poeira de rua ressuspensa, queima } \\
\text { de biomassa. Fontes naturais: pólen, aerossol, } \\
\text { marinho e solo. }\end{array}$ & $\begin{array}{l}\text { Danos à vegetação, deterioraçẫo } \\
\text { da visibilididade e contaminaçẫo } \\
\text { do solo. }\end{array}$ \\
\hline $\begin{array}{l}\text { Dióxido de Enxofre } \\
\qquad\left(\mathrm{SO}_{2}\right)\end{array}$ & $\begin{array}{l}\text { Gás incolor, com forte odor, semelhante } \\
\text { ao gás produzido na queima de palitos de } \\
\text { fósforos. Pode ser transformado a } \mathrm{SO}_{3^{\prime}} \text { que } \\
\text { na presença de vapor de água, passa rapida- } \\
\text { mente a } \mathrm{H}_{2} \mathrm{SO}_{4} \text {. É um importante precursor } \\
\text { dos sulfatos, um dos principais componentes } \\
\text { das particulas inaláveis. }\end{array}$ & $\begin{array}{l}\text { Processos que utilizam queima de óleo } \\
\text { combustivel, refinaria de petróleo, veiculos a } \\
\text { diesel, produçẫo de polpa e papel, fertilizantes. }\end{array}$ & $\begin{array}{l}\text { Pode levar à formaçãão de chuva } \\
\text { ácida, causar corrosão aos mate- } \\
\text { riais e danos à vegetaçâa: folhas } \\
\text { e colheitas. }\end{array}$ \\
\hline $\begin{array}{l}\text { Dióxido de } \mathrm{Ni} \text { - } \\
\text { trogênio }\left(\mathrm{NO}_{2}\right)\end{array}$ & $\begin{array}{l}\text { Gás marrom avermelhado, com odor forte } \\
\text { e muito irritante. Pode levar à formação de } \\
\text { ácido nitrico, nitratos (o qual contribui para o } \\
\text { aumento das partículas inaláveis na atmos- } \\
\text { fera) e compostos orgânicos tóxicos. }\end{array}$ & $\begin{array}{l}\text { Processos de combustão envolvendo veículos } \\
\text { automotores, processos industriais, usinas tér- } \\
\text { micas que utilizam óleo ou gás, incineraçōes. }\end{array}$ & $\begin{array}{l}\text { Pode levar à formação de chuva } \\
\text { ácida, danos à vegetaçãa e à } \\
\text { colheita. }\end{array}$ \\
\hline $\begin{array}{l}\text { Monóxido de } \\
\text { Carbono (CO) }\end{array}$ & Gás incolor, inodoro e insípido. & $\begin{array}{l}\text { Combustão incompleta em veiculos automo- } \\
\text { tores. }\end{array}$ & \\
\hline Ozônio $\left(0_{3}\right)$ & $\begin{array}{l}\text { Gás incolor, inodoro nas concentraçôes am- } \\
\text { bientais e o principal componente da névoa } \\
\text { fotoquímica. }\end{array}$ & $\begin{array}{l}\text { Não é emitido diretamente para a atmosfera. } \\
\text { É produzido fotoquimicamente pela radiaçẫo } \\
\text { solar sobre os óxidos de nitrogênio e compos- } \\
\text { tos orgânicos voláteis. }\end{array}$ & $\begin{array}{l}\text { Danos às colheitas, à vegetação } \\
\text { natural, plantaç̧es agricolas; } \\
\text { plantas ornamentais. }\end{array}$ \\
\hline
\end{tabular}


$\mathrm{O} \mathrm{CO}_{2}$ é o segundo principal gás de efeito estufa, sendo o primeiro o vapor d'água. O efeito estufa e o $\mathrm{CO}_{2}$ são essenciais para manutenção da vida na terra, sendo responsável pelo equilíbrio de temperatura e o $\mathrm{CO}_{2}$ o principal gás utilizado na fotossíntese.

Vários componentes do sistema climático afetam as concentrações dos gases de efeito estufa, e os mecanismos de compensação natural são complexos. $\mathrm{O}$ aumento da temperatura, que por consequência aumenta a concentração de vapor d'água, que novamente aumenta a temperatura, é apenas um desses mecanismos complexos [21] .

Embora não se consiga prever com exatidão os efeitos causados pelo aumento da concentração de $\mathrm{CO}_{2}$, não se tem dúvidas que esse provoca alterações climáticas nocivas, sendo necessárias medidas para sua redução.

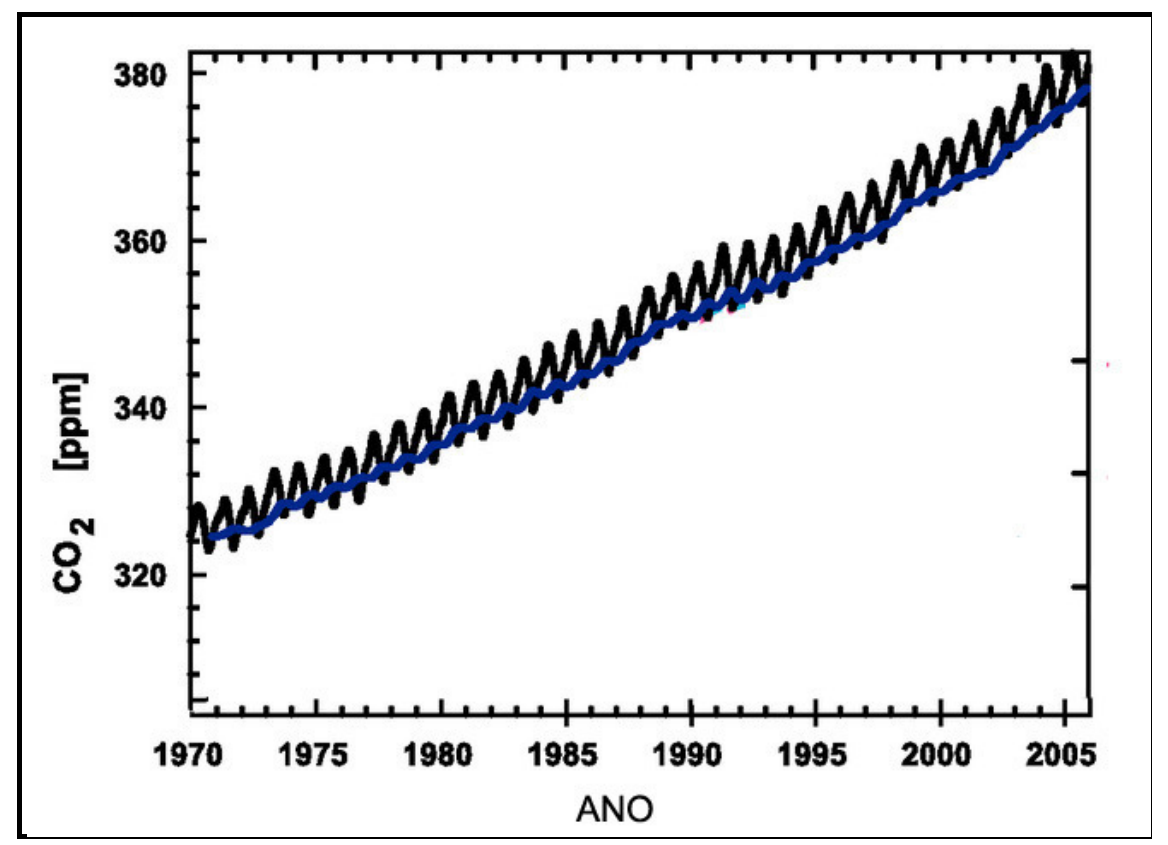

Figura 4 - Concentração de $\mathrm{CO}_{2}[22]$.

$\mathrm{Na}$ Figura 4, são apresentadas as concentrações de $\mathrm{CO}_{2}$ medidas pelos analisadores contínuos no Havaí (em preto) e na Nova Zelandia (em azul), comprovando o aumento das concentrações de $\mathrm{CO}_{2}$ desde o íncio das medições em 1970 até 2005.

Ainda são controversos os estudos que apontam os biocombustíveis como soluções para redução na emissão de $\mathrm{CO}_{2}$. Alguns consideram que o carbono liberado na queima do combustível é neutralizado pelo sequestro de carbono ocorrido no crescimento da cultura que o produziu, enquanto outros estudos analisam como aspectos negativos o fato de que áreas produtoras de alimentos seriam utilizadas na produção de biocombustíveis, e que a utilização 
de fertilizantes e o processo de produção do biocombustível também emite $\mathrm{CO}_{2}$. O Brasil esta em um posição estratégica, com grande capacidade de expansão na produção do etanol sem provocar prejuizos a outras culturas.

\subsubsection{Inspeção veicular}

A inspeção veícular veio para suprir a necessidade de uma fiscalização periódica. O PROCONVE estabelece normas principalmente para fabricação de veículos e a inspeção veícular estabele normas que impedem a circulação de veículos que, por falta de manutenção, passem a emitir poluentes acima dos estabelecidos.

No Brasil, todos os veículos que utilizam GNV são obrigados a passar por uma inspeção veicular, que estabelece limites de emissões definidas pelo Conselho Nacional do Meio Ambiente (CONAMA), segundo a resolução $n^{\circ}$ 007, de 31 de agosto de 1993, que define os limites máximos de Co, HC, diluição e velocidade angular do Motor, como apresentados na Tabela 3[23].

Tabela 3- Limites máximos de emissão de CO e HC corrigidos. (resolução CONAMA n ${ }^{\circ}$ 07/93)[23].

\begin{tabular}{|c|c|c|c|}
\hline \multirow[t]{3}{*}{ Ano/modelo } & \multirow{2}{*}{\multicolumn{3}{|c|}{$\begin{array}{l}\text { Marcha lenta }(900 \pm 300 \mathrm{rpm}) \\
\text { Acelerado sem carga }(2500 \mathrm{rpm} \pm 200 \mathrm{rpm})\end{array}$}} \\
\hline & & & \\
\hline & $\begin{array}{l}\text { COc Monóxido de } \\
\text { Carbono Corrigido }\end{array}$ & $\begin{array}{l}\text { Limite de HC Combustível } \\
\text { não queimado }\end{array}$ & $\begin{array}{l}\text { Diluição Mínima } \\
\%(\mathrm{CO}+\mathrm{CO} 2)\end{array}$ \\
\hline Até 1979 & 6 & 700 ppm & $6 \%$ \\
\hline De 1980 a 1988 & 5 & 700 ppm & $6 \%$ \\
\hline 1989 & 4 & 700 ppm & $6 \%$ \\
\hline 1990 - 1991 & 3 & 700 ppm & $6 \%$ \\
\hline 1992-1996 & 2 & 700 ppm & $6 \%$ \\
\hline A partir de 1997 & 1 & 700 ppm & $6 \%$ \\
\hline
\end{tabular}


Algumas cidades, como São Paulo, possuem o programa de inspeção veicular obrigatória para todos os veículos automotores, que estabelece limites de emissão, conforme Tabela 4 e

Tabela 5 [24]. Nessas cidades, os veículos a GNV são submetidos a duas inspeções anuais.

Tabela 4 - Limites máximos de emissão de CO Corrigido, em marcha lenta e a 2500 rpm, para veículos com motor do ciclo Otto (Resolução CONAMA 418, 25/11/2009) [24].

\begin{tabular}{lcccc}
\hline Ano de Fabricação & \multicolumn{4}{l}{ Limites de CO corrigido $(\%)$} \\
\cline { 2 - 5 } & Gasolina & Etanol & Flex & Gás Natural \\
Todos até 1979 & 6,0 & 6,0 & - & 6,0 \\
$\mathbf{1 9 8 0}-\mathbf{1 9 8 8}$ & 5,0 & 5,0 & - & 5,0 \\
$\mathbf{1 9 8 9}$ & 4,0 & 4,0 & - & 4,0 \\
$\mathbf{1 9 9 0 - 1 9 9 1}$ & 3,5 & 3,5 & - & 3,5 \\
$\mathbf{1 9 9 2 - 1 9 9 6}$ & 3,0 & 3,0 & - & 3,0 \\
$\mathbf{1 9 9 7 - 2 0 0 2}$ & 1,0 & 1,0 & - & 1,0 \\
$\mathbf{2 0 0 3 - 2 0 0 5}$ & 0,5 & 0,5 & 0,5 & 0,5 \\
$\mathbf{2 0 0 6}$ em diante & 0,3 & 0,5 & 0,3 & 0,3 \\
\hline
\end{tabular}

Tabela 5 - Limites máximos de emissão de HC corrigido, em marcha lenta e a 2500 rpm para veículos com motor do ciclo Otto. (Resolução CONAMA 418, 25/11/2009) [24].

\begin{tabular}{|c|c|c|c|c|}
\hline \multirow[t]{2}{*}{ Ano de Fabricação } & \multicolumn{4}{|c|}{ Limites de HC corrigido (ppm) } \\
\hline & Gasolina & Etanol & Flex & Gás Natural \\
\hline Todos até 1979 & 700 & 1100 & - & 700 \\
\hline $1980-1988$ & 700 & 1100 & - & 700 \\
\hline 1989 & 700 & 1100 & - & 700 \\
\hline 1990-1991 & 700 & 1100 & - & 700 \\
\hline 1992-1996 & 700 & 700 & - & 700 \\
\hline 1997-2002 & 700 & 700 & - & 700 \\
\hline 2003-2005 & 200 & 250 & 200 & 500 \\
\hline 2006 em diante & 100 & 250 & 100 & 500 \\
\hline
\end{tabular}

O fator de diluição dos gases de escapamento deve ser igual ou inferior a 2,5. No caso de fator de diluição ser inferior a 1,0 este deverá ser considerado como igual a 1,0 para o cálculo dos 
valores corrigidos de $\mathrm{CO}$ e $\mathrm{HC}$.

Os valores de Co corrigido e HC corrigido são calculados conforme eq.(4) e eq.(5) abaixo

$$
\begin{aligned}
& C O_{\text {corrigido }}=\frac{15}{(C O+C O 2)} \times C O_{M e d i d o} \\
& H C_{\text {corrigido }}=\frac{15}{(C O+C O 2)} \times H C_{\text {medido }}
\end{aligned}
$$

Fator de diluição dos gases do escapamento é a razão volumétrica de diluição da amostra de gases de escapamento devia a entrada de ar no sistema, dada pela eq.(6) [24].

$$
F_{\text {diluição }}=\frac{15}{(\mathrm{CO}+\mathrm{CO})_{\text {medidos }}}
$$

\subsubsection{Reciclagem}

As normas que estabelecem os limites de emissão consideram o ano de fabricação do veículo, respeitando os limites tecnológicos da época de sua fabricação. Conforme observado nas tabelas de emissões do item 2.4.3, um veículo novo obedece a limites mais exigentes de emissões, sendo necessária a renovação da frota para que uma maior redução ocorra, principalmente em países como o Brasil, que possuem uma frota com alta idade média.

No final da década de 90, com objetivo de incentivar as vendas de veículos, as montadoras articularam o chamado Plano de Renovação da Frota, que previa bônus para compra de veículos novos aos proprietários de veículos antigos que os entregassem a reciclagem. Este plano tinha aspectos positivos, onde se dava um destino correto ao veículo antigo, reciclando boa parte de seu material, principalmente o aço. Considerando que um veículo novo polui menos que um veículo antigo, a redução na idade média da frota traria benefícios com a redução de poluentes.

Um dos aspectos negativos desse plano era incentivar a aquisição de um veículo novo por um consumidor com renda incompatível com seus custos, que mesmo que seja reduzido em 
manutenção incial, tem alto custo de impostos e seguros. O ideal é a redução no preço do veículo novo provoque naturalmente uma renovação no mercado de usados, reduzindo a idade média da frota nacional.

O interesse das montadoras no plano de reciclagem desapareceu após a década de 90 com a recuperação do setor automotivo, que chegava a recordes de vendas mesmo em 2009 em plena crise financeira mundial [25].

No Brasil, faltam planejamento e incentivos para a formação de uma rede, voltada à desmontagem, coleta e trajeto final dos materiais reciclados. As partes metálicas, principalmente o aço, ainda são as mais recicladas. Entretanto, a redução da participação dos metais devido à substituição por materiais plásticos ou compósitos, provocou a redução na parcela de materiais recicláveis, criando um novo desafio na busca de soluções para destinação correta desses materiais[26].

\subsection{ETANOL PRÉ-VAPORIZADO}

A principal razão na vaporização do combustível é tornar o combustível e o ar uma mistura homogênea, sem pontos de mistura rica ou pobre. Para que o processo de vaporização seja eficiente, é necessário que o combustível utilizado seja de composto único para que, em uma temperatura constante, todo o produto seja vaporizado, sem separação de fases. Etanol e metanol possuem essa característica. Porém, a gasolina é composta de dezenas de hidrocarbonetos, inviabilizando uma vaporização adequada.

O etanol pré-vaporizado foi utilizado por Romeu Corsini[27], que apresentou seu pedido de patente em 1977, e após modificações na patente, esta foi aprovada somente em 1989, com o título "Processo e equipamento para alimentação de motores de combustão interna movidos a álcool" [27].

O invento de Corsini era um processo com respectivo equipamento para alimentação de motores de combustão interna, movidos, preferencialmente, a etanol hidratado ou com combustíveis de composto único [27].

Segundo Corsini, o processo convencional da época, o carburador, apresentava alguns inconvenientes, dos quais podem ser citados os seguintes.

A vaporização efetuando-se em grande parte na câmara de combustão, retira do sistema a energia correspondente ao calor latente de vaporização, energia essa que poderia aumentar a 
pressão e, conseqüentemente, a força no tempo motor[27] .

A mistura é imperfeita, contendo pontos de mistura correta, uns de rica e outros de pobre, e outros, ainda, além dos limites superior e inferior de combustão. Assim sendo, a combustão também é imperfeita, completando-se na fase de escapamento e nos dutos de escape, reduzindo o rendimento do processo, além de provocar danos mecânicos e corrosão nos dutos de escape e silenciador [27].

No caso da gasolina, outro fator contribui para a redução da eficiência do processo é o seu baixo índice de octanagem, que obriga o motor a trabalhar com taxa de compressão baixa e consequentemente um baixo rendimento termodinâmico [27].

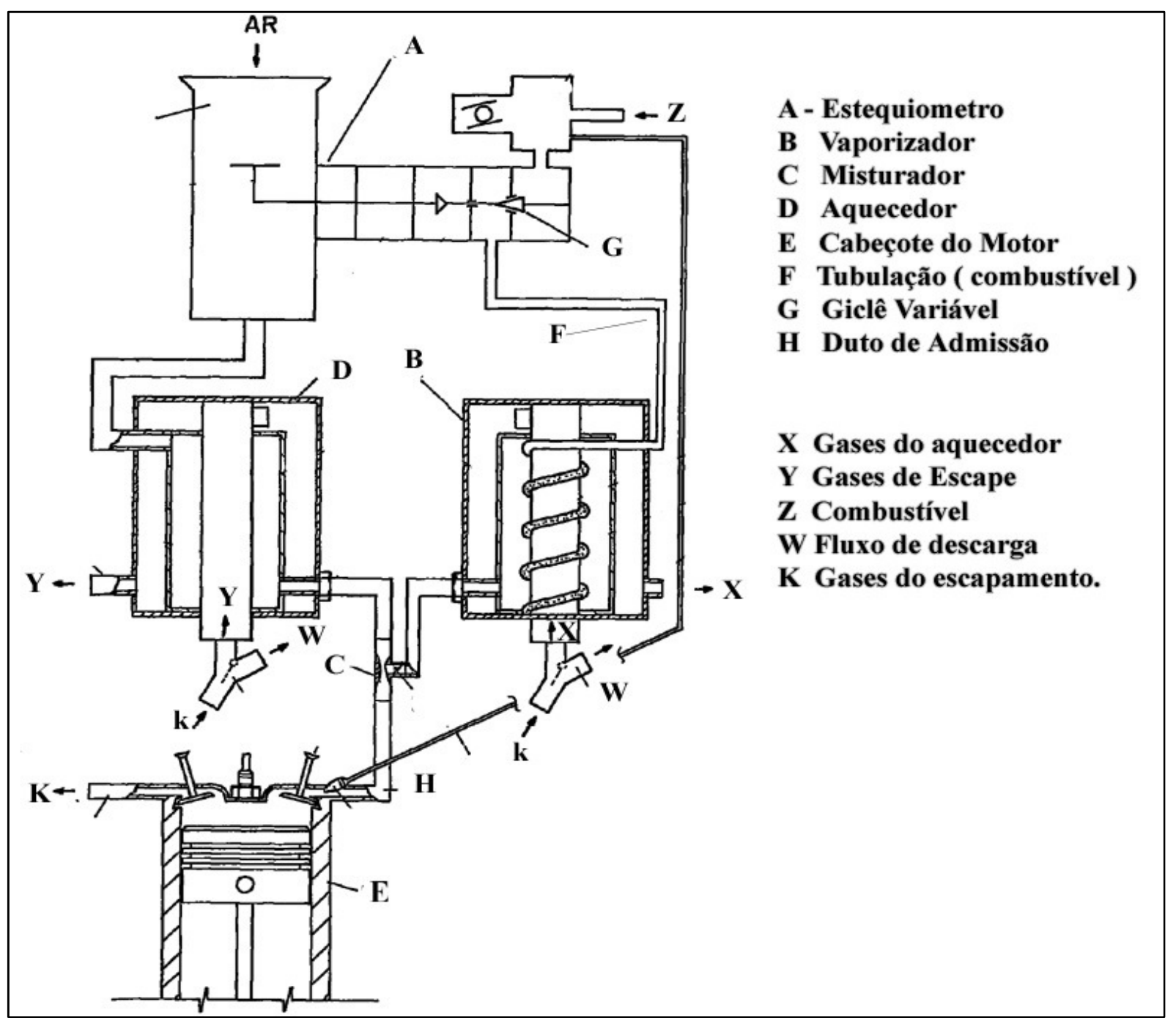

Figura 5 - Esquema de alimentação com combustível pré-vaporizado [27].

A invenção de Corsini consiste em dosar o combustível através de um estequiômetro mecânico ou eletrônico, sendo que o combustível líquido passa para fase vapor por meio de 
um vaporizador antes de chegar na câmara de combustão.

Na Figura 5, é apresentado o esquema de alimentação do combustível pré-vaporizado, que tem como objetivo dosar o combustível através do Giclê variável (G), em relação à quantidade de ar admitido no coletor do estequiometro (A), vaporizando o combustível líquido e misturando com o ar aquecido na proporção estequiométrica através do misturador (C) [27].

\subsection{CONVERSÃO PARA GNV E SUA EVOLUÇÃO}

Os dispositivos para conversão de veículos originais a gasolina ou flex para GNV têm como principio básico o uso do combustível líquido ou gasoso, onde sua seleção pode ser feita com o veículo em movimento.

Nesse capítulo, são apresentadas as fases da evolução dos sistemas de conversão, embora possam representar uma sequência evolutiva. Os sistema de $1^{\mathrm{a}} 2^{\mathrm{a}}$ e $5^{\mathrm{a}}$ gerações são atualmente comercializados no Brasil, sendo que o de $1^{\text {a }}$ geração é o mais comum.

\subsubsection{Primeira geração de conversores para GNV}

A primeira fase do GNV, chamada de GNV de primeira geração, como é mostrado na Figura 6, trata-se de um sistema semelhante ao carburador. A entrada de combustível ocorre por aspiração provocada pela depressão do cilindro. Essa aspiração é controlada apenas por essa depressão, que por sua vez, é controlada por uma borboleta acionada pelo pedal do acelerador. Não existe um controle preciso da injeção do combustível.

A única parte elétrica dos primeiros sistemas eram as válvulas solenóides, responsáveis pela abertura ou obstrução da passagem dos combustíveis.

Mesmo antes da existência de postos de GNV, havia instalações irregulares que utilizavam cilidros de gás de cozinha GLP, essas instalações não atendiam as normas de segurança e não eram permitidas, no entando traziam o benefício econômico.

A conversão de veículos com o sistema de primeira geração ainda é muito usada. Mesmo em veículos com injeção eletrônica, o controle eletrônico é reponsável apenas pela seleção dos 
combustíveis, emulação das válvulas injetoras e sensor de oxigênio. Nenhum controle da mistura é feita nesse sistema.

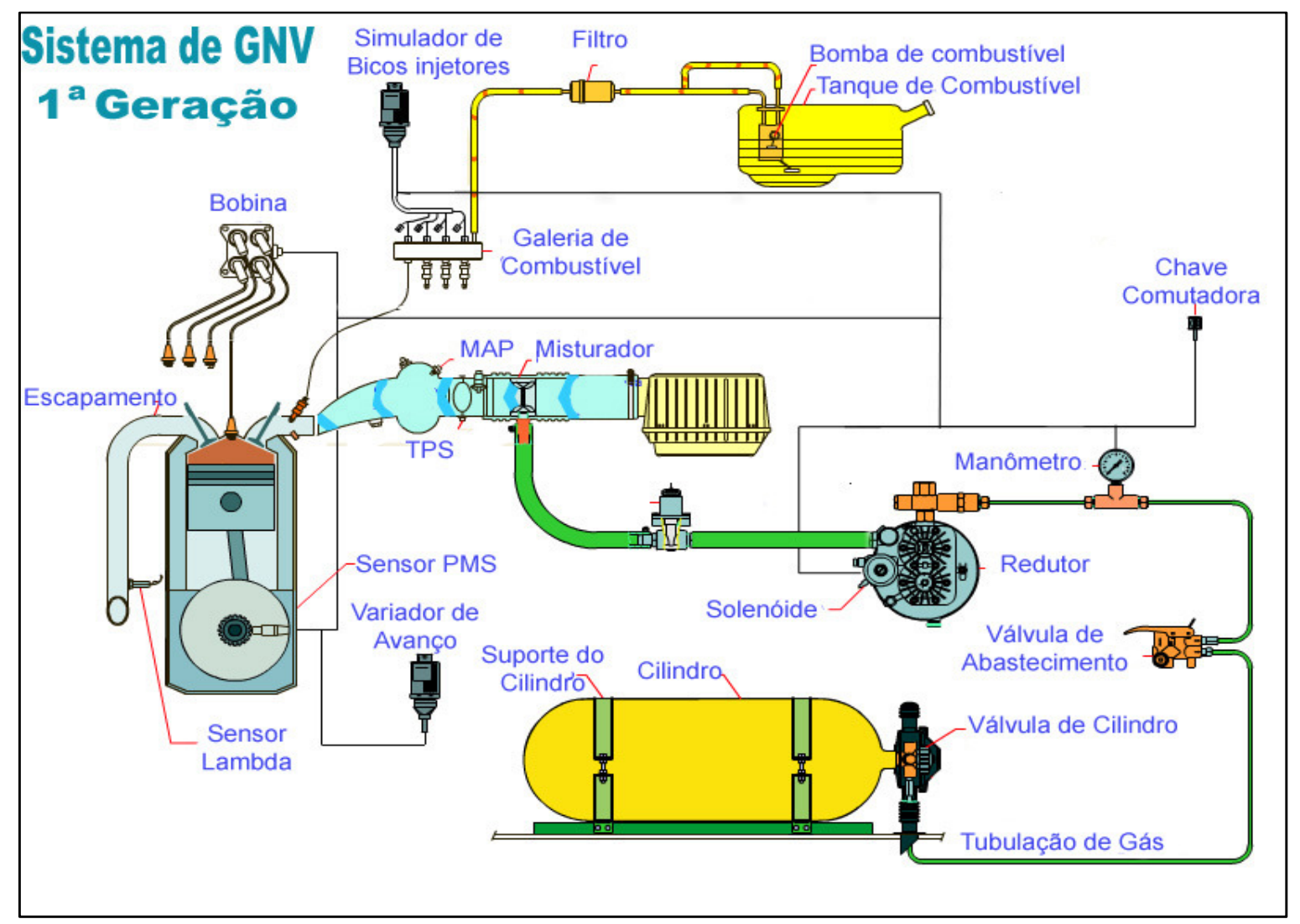

Figura 6 - Sistema de conversão GNV 1a geração[28].

\subsubsection{Segunda geração de conversores para GNV}

A segunda geração dos sistemas de conversão para GNV tem funcionamento semelhante ao sistema de primeira geração. Sua principal diferença é a introdução do atuador eletrônico para controle do fluxo de gás, que tem abertura proporcional à rotação do motor.

$\mathrm{Na}$ Figura 7, é apresentado o sistema de $2^{\mathrm{a}}$ geração, destacando, no círculo vermelho, o atuador de fluxo. 


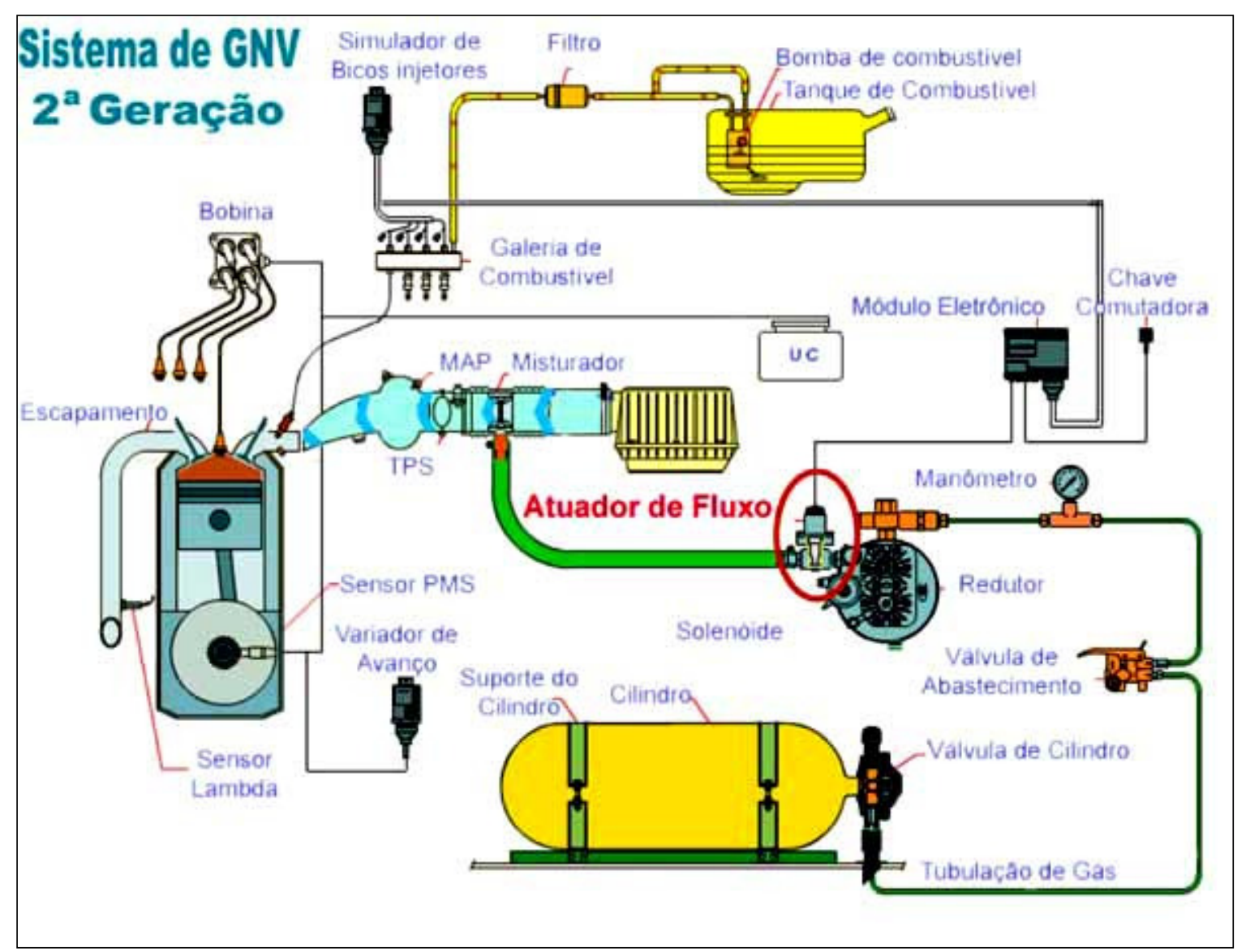

Figura 7 - Sistema de conversão GNV de $2^{\mathrm{a}}$ geração [28].

\subsubsection{Terceira geração de conversores para GNV}

A terceira geração dos sistemas de conversão para GNV é muito semelhante ao sistema de $2^{\mathrm{a}}$ geração. Seu diferencial é o uso de dois atuadores para o controle do fluxo. Na Figura 8, temse o sistema de $3^{\text {a }}$ geração, onde é destacado, pelos circulos em vermelho, o atuador acoplado no redutor de pressão responsável pelo controle principalmente da marcha lenta, e o atuador principal para controle quando a rotação estiver acima da marcha lenta. 


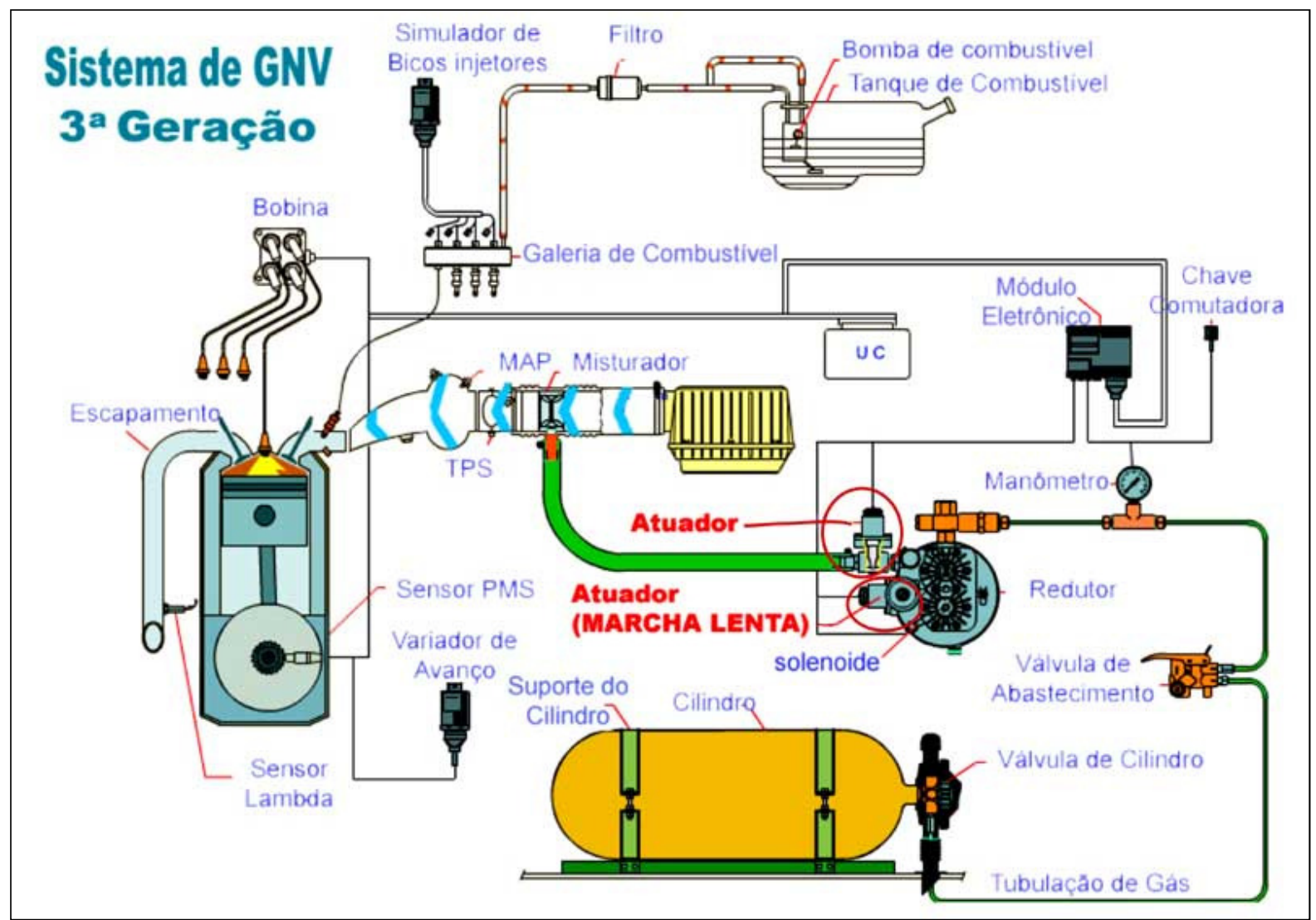

Figura 8 - Sistema de conversão GNV de $3^{\text {a }}$ geração [28] •

\subsubsection{Quarta geração de conversores para GNV}

A quarta geração de conversores para GNV se diferencia das gerações anteriores, pois a pressão de trabalho no redutor é positiva. O controle do fluxo de gás é feito por dois atuadores e por um distribuidor de gás. Após o atuador, a aspiração ainda é necessária para completar a distribuição. Sua principal vantagem é não ser mais necessário o uso do misturador, que funciona como um obstáculo na entrada de ar. Na Figura 9 é apresentado o sistema de $4^{\text {a }}$ geração, com seus dois atuadores e o distribuidor de gás. 


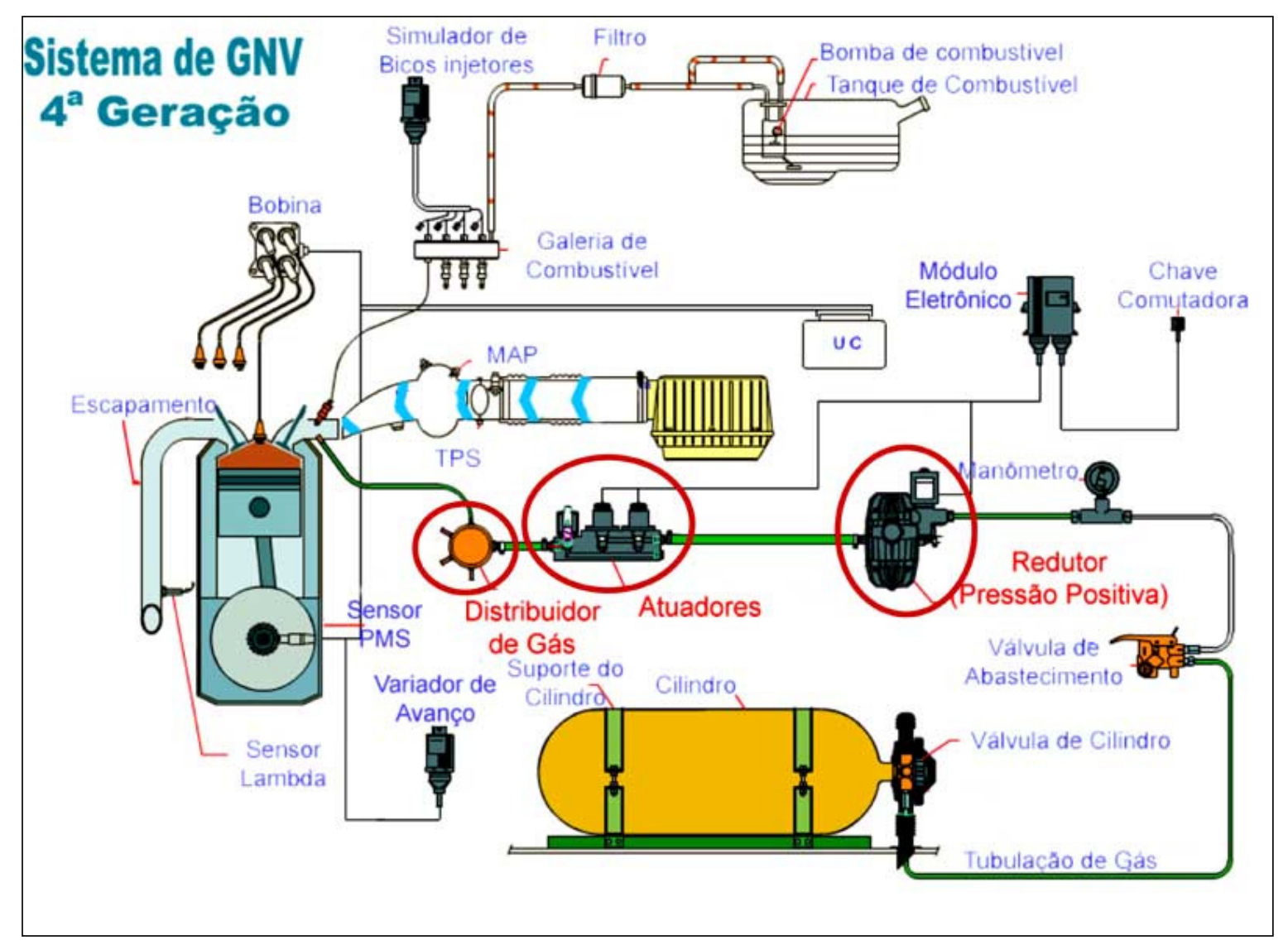

Figura 9 - Sistema de conversão GNV de $4^{\text {a }}$ geração [28].

\subsubsection{Quinta geração de conversores para GNV}

O sistema de quinta geração trabalha com pressão positiva na linha de combustível. A injeção é feita pelas válvulas injetoras, de forma muito semelhante ao sistema de injeção de combustível líquido multiponto. Entretanto esse sistema ainda possui um custo elevado.

O veículo gol utilizado nos testes custa em torno de $\mathrm{R} \$ 26000,00$. A conversão desse veículo custa em média 3800,00 (ver Anexo A), representando 14\% do preço do veículo.

Esse sistema aciona as válvulas injetoras do GNV, calculando o tempo de abertura baseado no tempo de injeção enviado pela UCE (Unidade Central Eletrônica) original.

O sistema não utiliza nenhuma estratégia para compensar a perda de potência causada pelo GNV, não utiliza a injeção simultânea com o combustível líquido, mas é o sistema que apresenta maior eficiência volumétrica quando comparada com as gerações anteriores. 


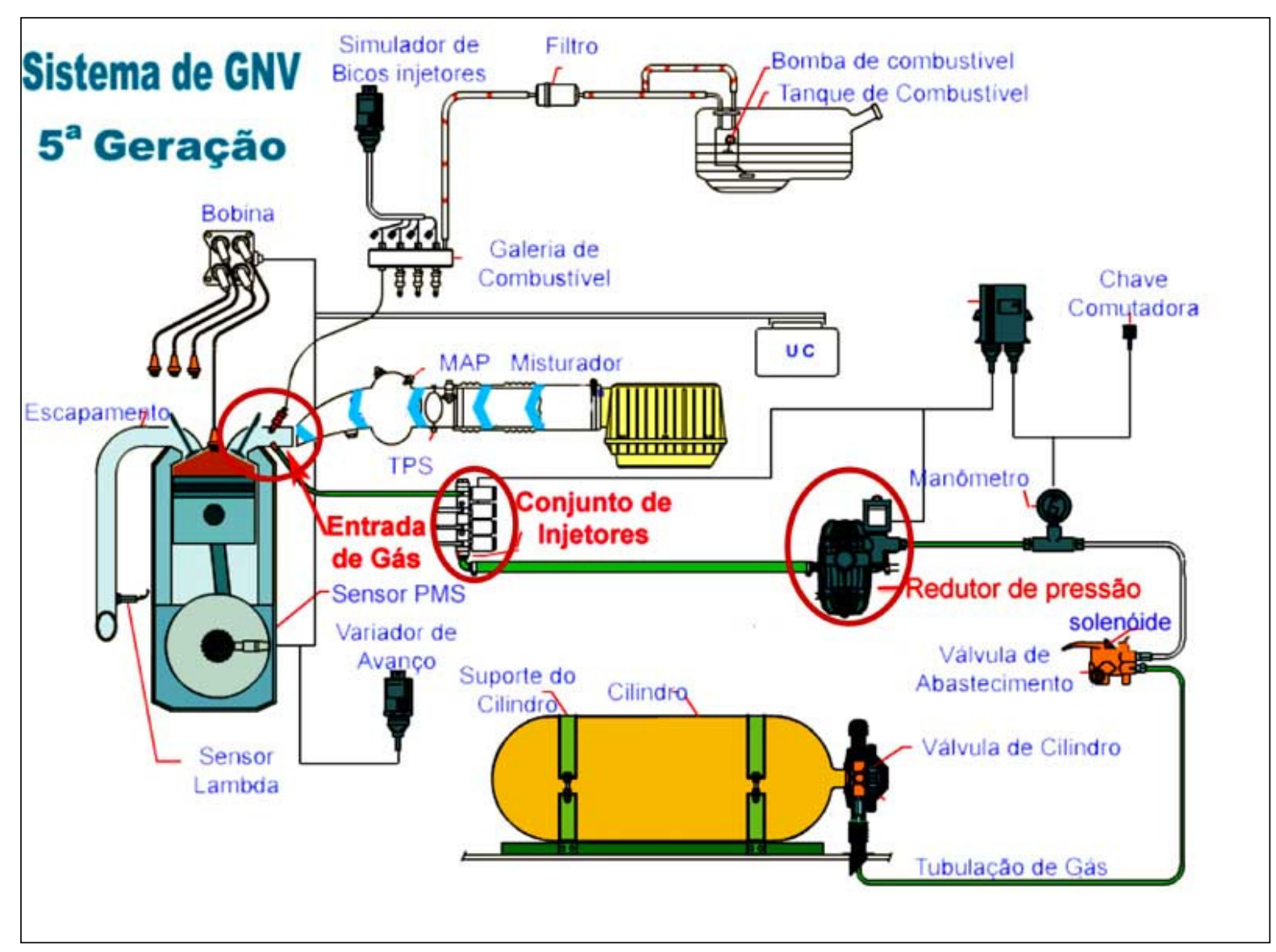

Figura 10 - Sistema de conversão GNV de $5^{\text {a }}$ geração [28] •

Na Figura 10, é apresentado o sistema de quinta geração. Seu principal diferencial em relação aos sistemas anteriores é o uso de uma válvula injetora por cilindro e o reduto de pressão positiva, destacados pelos círculos em vermelho.

\subsection{TRICOMBUSTÍVEL ORIGINAL}

Existem poucos veículos no mercado que já saem de fábrica com o sistema tricombustível. O sistema da Bosch, chamado de Trifuel, que possibilita o uso do GNV, gasolina, etanol ou qualquer mistura dos dois últimos combustíveis no mesmo veículo, não prevê o uso simultâneo do GNV junto ao combustível líquido. O sistema tricombustível da Bosch foi desenvolvido para ser usado pelas montadoras para equipar veículos originais, não possuindo nenhuma linha de kits para conversão [29] . 
A Magneti Marelli possui seu sistema tricombustível chamado de tetra-fuel, sendo que a empresa considera como quarto combustível a gasolina sem adição de etanol. Seu funcionamento é semelhante ao sistema Bosch, diferenciando-se apenas na técnica para compensar a perda de potência do GNV, com a troca automática do combustível em momentos que é exigido maior potência.

\subsubsection{Sistema tricombustível da Delphi}

Um dos veículos tricombustível original é o Corsa Multipower, com injeção eletrônica da Delphi. Esse modelo utiliza apenas uma UCE para controlar a injeção do combustível líquido, Etanol e/ou gasolina e o GNV.

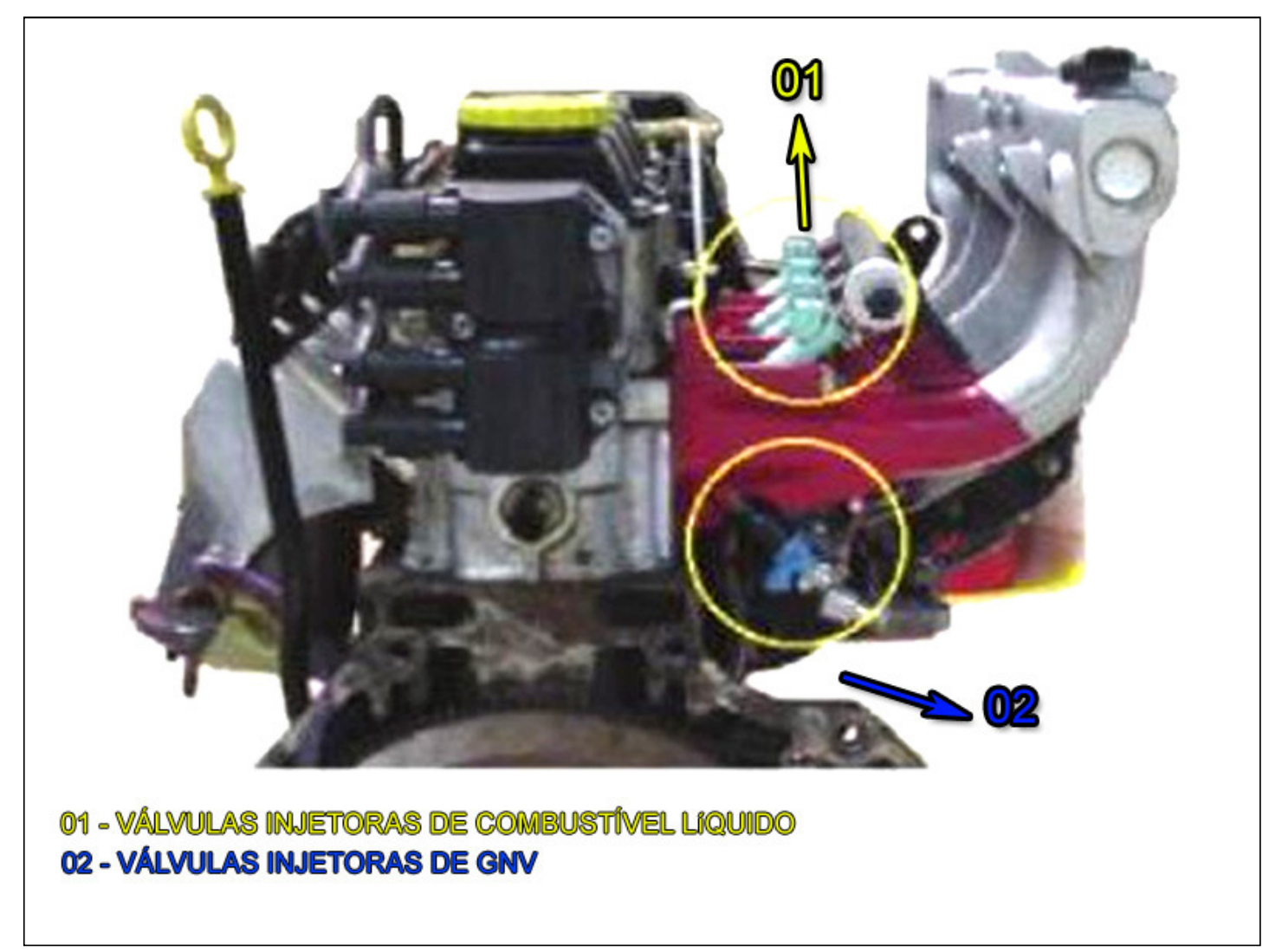

Figura 11 - Motor GM MultiPower [30]. 
As válvulas injetoras do combustível líquido são instaladas na posição convencional. As válvulas para injeção do GNV são instaladas na parte de baixo do coletor de admissão, como apresentadas na Figura 11.

O desempenho com o uso do GNV foi inferior quando comparado com a gasolina e o etanol, que é característica do GNV, pois ocupa um espaço maior no cilindro, diminuindo a quantidade de ar admitida [30].

Na Tabela 6, observa-se a perda de potência, torque, aceleração e velocidade final com o uso do GNV. Entretanto, a redução do custo do consumo relativo para $43 \%$ é muito significante.

Tabela 6 - Performance do veículo Corsa MultiPower com Gasolina , etanol e GNV [30].

\begin{tabular}{lccc}
\hline Combustíveis & Gasolina Brasileira & Etanol & GNV \\
\hline Motorização & \multicolumn{3}{c}{ C18XE 4 Cilindros SOHC 1.8 } \\
Taxa de compressão & \multicolumn{3}{c}{10.5} \\
Potência Máxima & $77.2 \mathrm{KW}$ & $80.2 \mathrm{KW}$ & $67.2 \mathrm{KW}$ \\
& $104,9 \mathrm{CV}$ & $109,04 \mathrm{CV}$ & $91,37 \mathrm{CV}$ \\
\hline rpm & 5400.00 & 5400.00 & 5400.00 \\
\hline Torque (Nm) & 170.00 & 178.00 & 148.00 \\
\hline Transmissão & 182 & 184 & 175 \\
\hline Velocidade máxima & $10.6 \mathrm{~s}$ & $10.4 \mathrm{~s}$ & $11.2 \mathrm{~s}$ \\
\hline Aceleração de 0 a 100Km/h & 11 & & 14.7 \\
\hline Consumo (NBR7024) & 16.3 & 7.6 & 18.7 \\
\hline Cidade (Km.H-1) & 100 & 82 & 43 \\
\hline Estrada & & & \\
\hline Custo relativo por Km(\%) & & & \\
\hline
\end{tabular}




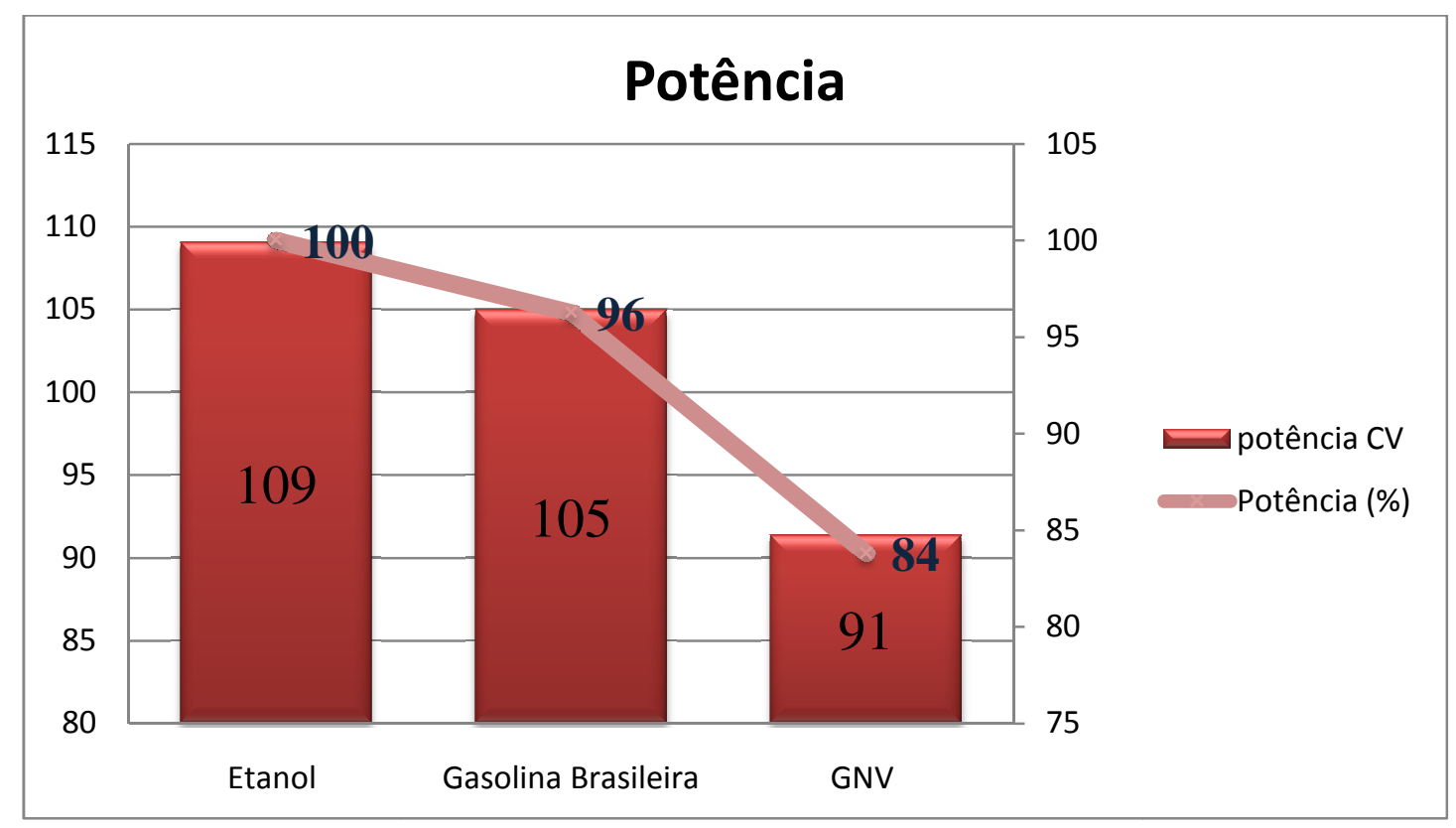

Gráfico 1 - Potência X Combustível, para o Corsa Multipower[30].

No Gráfico 1, observa-se a perda de potência, chegando a $84 \%$ da potência obtida com o Etanol, uma perda de $16 \%$ compensada economicamente, conforme demonstrado no Gráfico 2, através do custo relativo calculado utilizando a média de preços de 2009 na cidade de São Paulo.

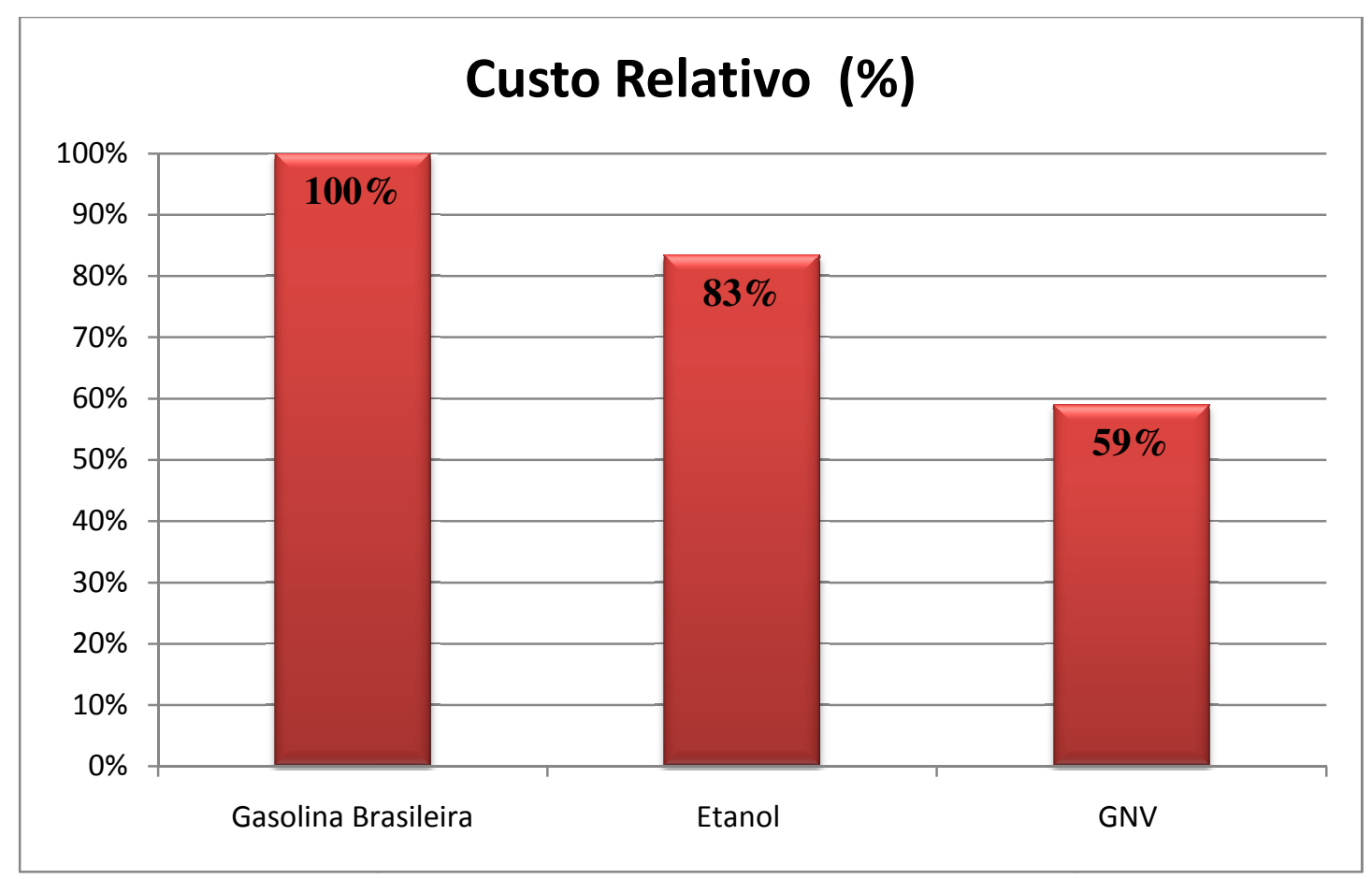

Gráfico 2 - Custo Relativo dos combustíveis[30]. 


\subsection{PREÇOS DOS COMBUSTÍVEIS}

Diversos são os fatores que influenciam na formação de preço dos combustíveis, tornando difícil uma previsão de preços. Analisando os preços de 2009 para a cidade de São Paulo, apresentado no Gráfico 3, obtido a partir da Tabela 7, observa-se uma estabilidade da gasolina, e forte variação no Etanol e GNV.

Tabela 7 - Preço médio em reais dos combustíveis na cidade de São Paulo no ano de 2009.[31]

\begin{tabular}{lccc}
\hline Meses & Gasolina & Etanol & GNV \\
\hline Janeiro & 2,39 & 1,31 & 1,73 \\
Fevereiro & 2,40 & 1,33 & 1,74 \\
Março & 2,39 & 1,33 & 1,73 \\
Abril & 2,37 & 1,28 & 1,72 \\
Maio & 2,37 & 1,26 & 1,72 \\
Junho & 2,35 & 1,18 & 1,60 \\
Julho & 2,34 & 1,21 & 1,53 \\
Agosto & 2,35 & 1,23 & 1,53 \\
Setembro & 2,36 & 1,31 & 1,50 \\
Outubro & 2,40 & 1,50 & 1,53 \\
Novembro & 2,43 & 1,55 & 1,50 \\
Dezembro & 2,44 & 1,60 & 1,50 \\
\hline
\end{tabular}

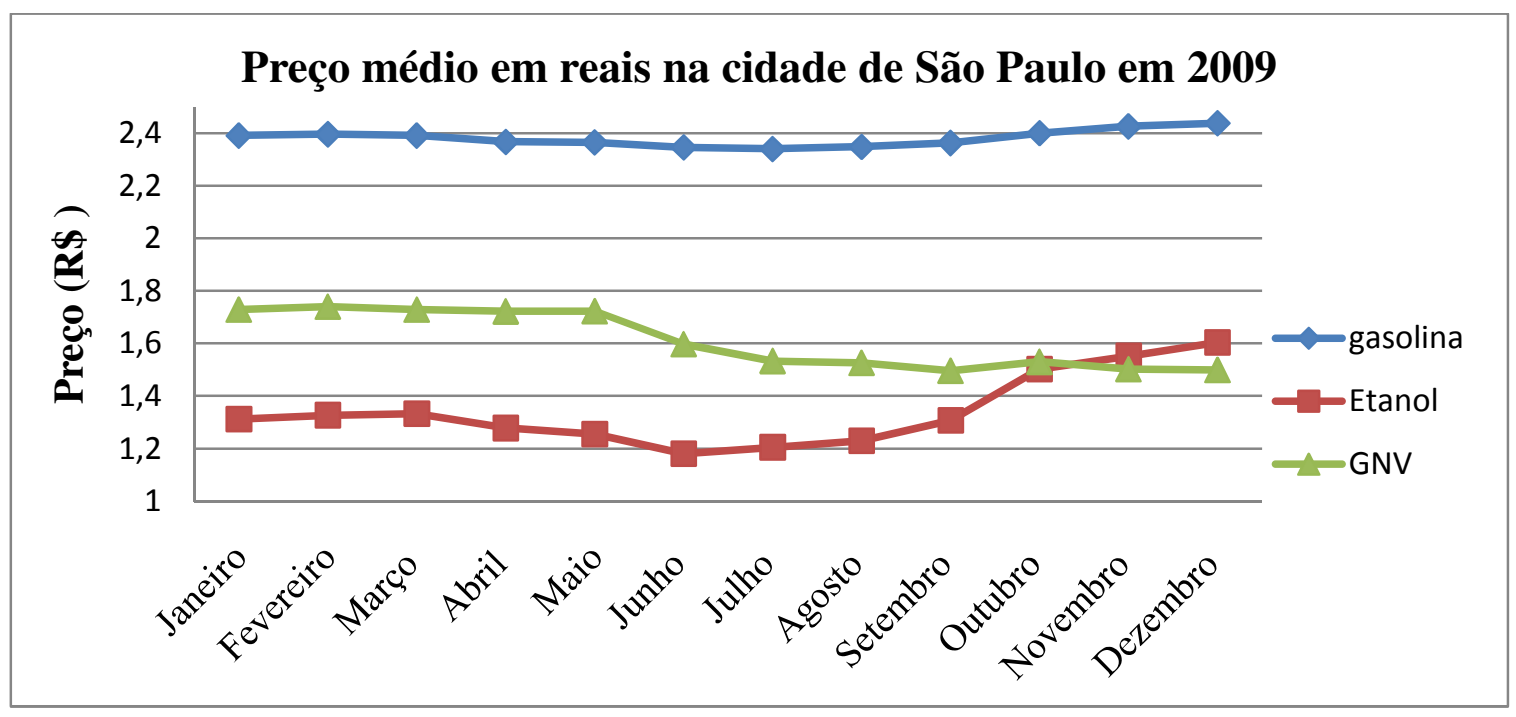

Gráfico 3 - Preço médio dos combustíveis na cidade de São Paulo em 2009[31]. 
Tabela 8 - Preço médio praticado no Brasil em 2009[31].

\begin{tabular}{lccc}
\hline Meses & Gasolina & Etanol & GNV \\
\hline Janeiro & 2,51 & 1,51 & 1,78 \\
Fevereiro & 2,51 & 1,53 & 1,74 \\
Março & 2,51 & 1,51 & 1,72 \\
Abril & 2,50 & 1,48 & 1,70 \\
Maio & 2,49 & 1,44 & 1,67 \\
Junho & 2,48 & 1,39 & 1,61 \\
Julho & 2,49 & 1,42 & 1,58 \\
Agosto & 2,49 & 1,44 & 1,58 \\
Setembro & 2,47 & 1,48 & 1,53 \\
Outubro & 2,51 & 1,62 & 1,58 \\
Novembro & 2,54 & 1,69 & 1,59 \\
\hline Dezembro & 2,54 & 1,72 & 1,60 \\
\hline
\end{tabular}

No Gráfico 4, obtido a partir dos dados da Tabela 8, têm-se os preços médios para todo o Brasil. Observam-se as mesmas oscilações ocorridas em São Paulo, principalmente de maio a setembro, onde ocorre forte alta do etanol e redução do GNV.

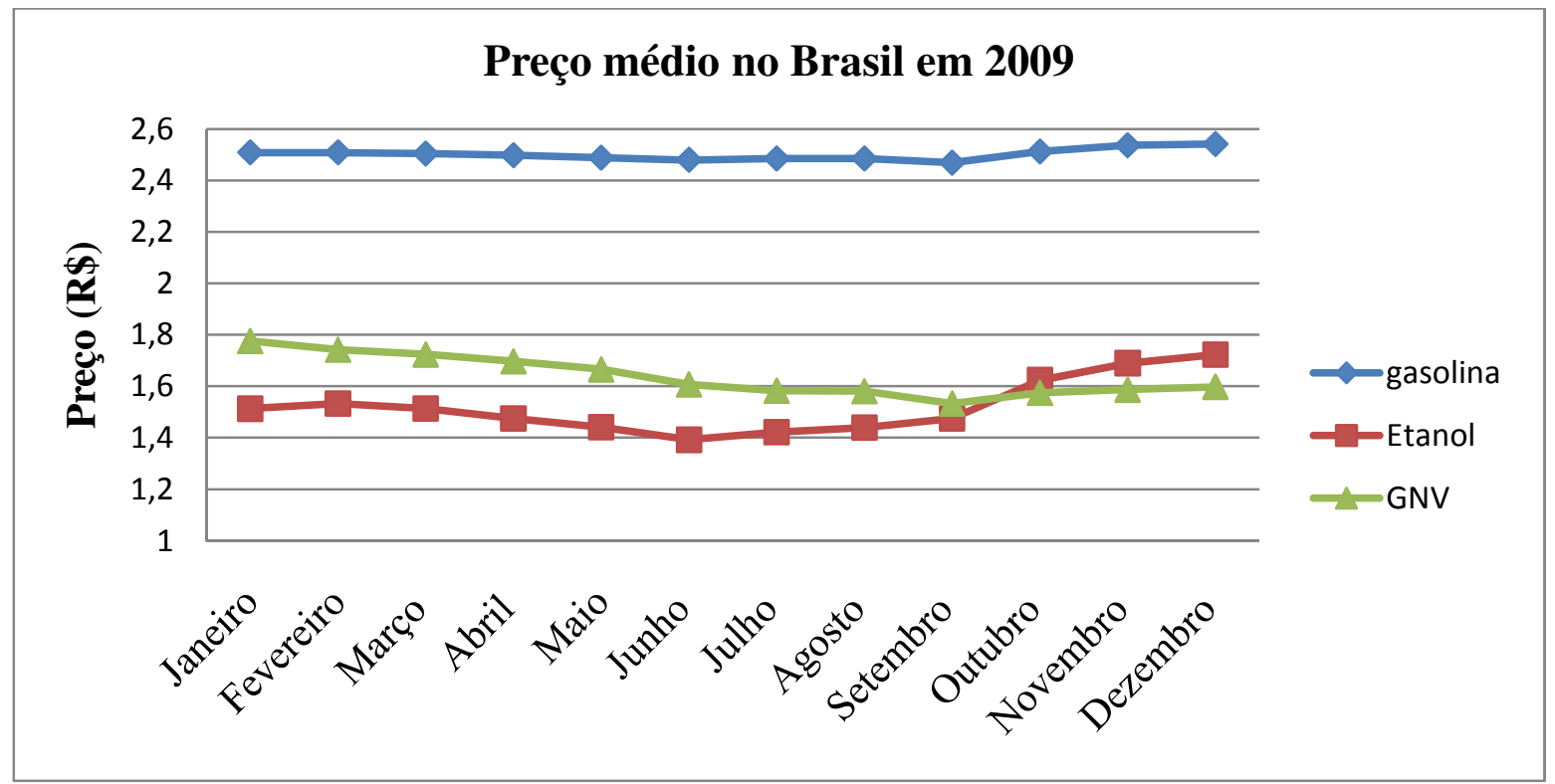

Gráfico 4 - Preço médio dos combustíveis no Brasil em 2009[31]. 


\section{MATERIAIS E MÉTODOS}

Nesse capítulo são apresentados os veículos e os materiais utilizados para o desenvolvimento e testes do protótipo desenvolvido. No item 3.1, são descritos as características dos veículos e combustíveis utilizados, no item 3.2, tem-se a descrição do sistema de injeção eletrônica utilizado no desenvolvimento do sofware, descrevendo os principais sensores e atuadores utilizados, incluindo o sistema de comunicação entre o módulo principal e potência.

No item 3.3 são apresentados detalhes da construção do dispositivo protótipo, seu funcionamento e instalação no veículo e o circuito de leitura dos principais sensores. No item 3.4, é apresentada a lógica de controle com equações utilizadas no sofware do protótipo desenvolvido. No item 3.5, tem-se descrição da instalação do sistema de conversão para GNV aspirado. No item 3.6, é descrita a tentativa de uso do GNV utilizando as válvula injetoras originais do veículo e, por fim, o item 3.7 descreve a instalação do sistema de injeção positiva de GNV utilizando o protótipo desenvolvido.

\subsection{MATERIAIS UTILIZADOS}

Nesse capítulo são apresentados os materiais, veículos e combustíveis utilizados.

\subsubsection{Veículos de teste}

Para os testes foram utilizados dois veículos com as características originais descritas na Tabela 9 e Tabela 10 .

Tabela 9 - Descrição do veículo de teste Daewoo Lanos.[32]

\begin{tabular}{ll}
\hline & Daewoo Lanos \\
\hline Marca & Daewoo \\
Motorização & $1.6 \mathrm{~L} \mathrm{16v} \mathrm{DOHC}$ \\
Ano/modelo & $1998 / 1999$ \\
País de Origem & Coreia \\
Combustível original & Gasolina \\
Potência Original & $77,8 \mathrm{KW}(105,77 \mathrm{cv})$ a $6000 \mathrm{rpm}$ \\
Peso Bruto & $1072 \mathrm{Kg}$ \\
Reservatório de Combustível & $48 \mathrm{~L}$ \\
\hline Sistema de injeção & Multiponto semi-sequencial \\
\hline
\end{tabular}




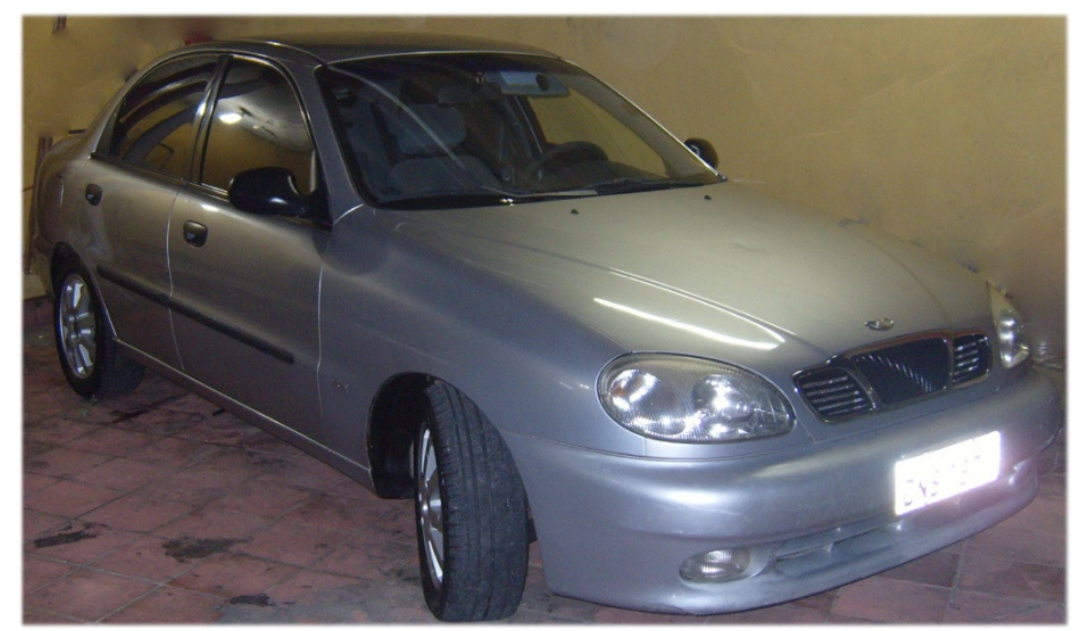

Figura 12 - Daewoo Lanos 1999[33]

O Daewoo Lanos foi homologado no Inmetro (Instituto Nacional de Metrologia, Normalização e Qualidade Industrial) e Registrado no Detran (Departamento Estadual de Trânsito) para (Gas/Alc/GNV), conforme Anexo B.

Tabela 10 - Descrição do veículo de teste VW Gol.[34]

\begin{tabular}{llc}
\hline & \multicolumn{1}{c}{ Gol GIV } \\
\hline Motorização & $1.0 \mathrm{~L} \mathrm{8v}$ \\
Ano/modelo & $2009 / 2010$ & \\
\hline $\begin{array}{l}\text { País de Origem } \\
\text { Combustível original }\end{array}$ & Brasil & \multicolumn{1}{c}{ Gasolina / Etanol } \\
\hline $\begin{array}{l}\text { Potência Original } \\
\end{array}$ & \multicolumn{1}{c}{ Gasolina } & \\
& $50 \mathrm{KW}(68 \mathrm{cv})$ a $5750 \mathrm{rpm}$ & $52 \mathrm{KW}(71 \mathrm{cv})$ a $5750 \mathrm{rpm}$ \\
Peso Bruto & $855 \mathrm{Kg}$ & \\
Reservatório de Combustível & $55 \mathrm{~L}$ & \\
Sistema de Injeção & Multiponto sequencial & \\
\hline
\end{tabular}

O VW Gol foi homologado no Inmetro e Registrado no Detran para (Gas/Alc/GNV), conforme Anexo C.

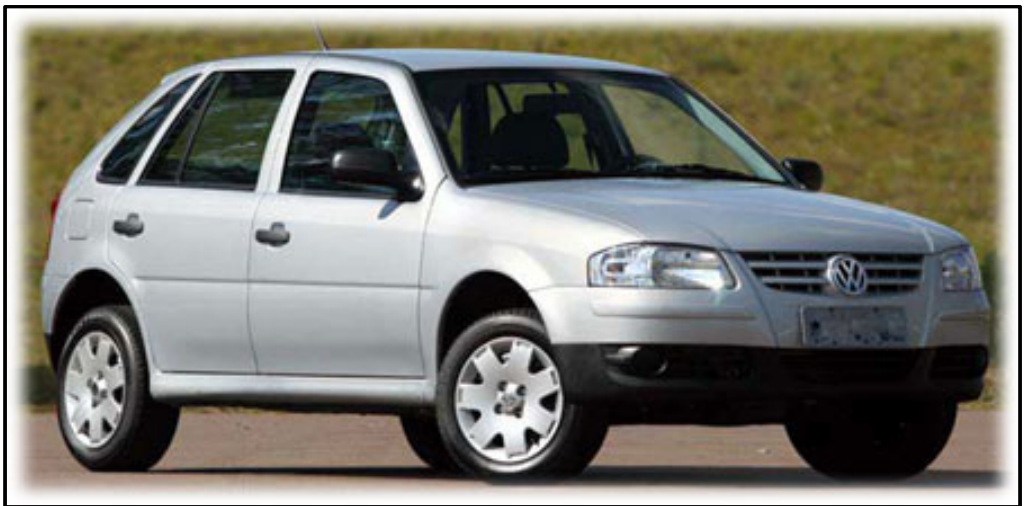

Figura 13 - Volkswagen Gol GIV 2009.[33] 


\subsubsection{Materiais utilizados no sistema de GNV.}

Na Tabela 11 e Tabela 12, são descritos os principais materiais utilizados para a conversão do veículo para GNV.

Tabela 11 - Materiais utilizados no sistema de GNV aspirado [33].

\begin{tabular}{lll}
\hline & Sistema Conversão GNV aspirado & \\
\hline Descrição & Modelo & Fabricante \\
Redutor de pressão & Redução de 200bar a Pressão atmosférica & BRC \\
Válvula de Abastecimento & Simples interna & BRC \\
Variador de avanço & T30 & Tury \\
Emulador de Bicos & Analógico com relê & WMTM \\
Chave Comutadora & T1000 & Tury \\
Manometro de Pressão & T800 & Tury \\
Válvula solenoide & 12 V NF(normalmente fechada) & BRC \\
Cilindro de GNV & Modelo 7,5 m ${ }^{3}$ & Cilbras \\
\hline
\end{tabular}

Tabela 12 - Materiais utilizados no sistema de conversão com injeção positiva de GNV [33].

\begin{tabular}{lll}
\hline \multicolumn{2}{l}{ Sistema Conversão GNV com injeção positiva } & \\
\hline Descrição & Modelo & Fabricante \\
\hline Redutor de pressão & Redução de 200bar a 2bar & BRC \\
Válvula de Abastecimento & Simples interna & BRC \\
Variador de avanço & T30 Lanos / T37 Gol & Tury \\
\hline Manometro de pressão & $\begin{array}{l}\text { Integrado ao redutor com saida } \\
\text { analógica }\end{array}$ & \\
Válvula solenoide & 12V NF(normalmente fechada) & BRC \\
Conjunto de $\quad$ válvulas & Sequent Point & BRC \\
injetoras & & \\
Cilindro de GNV & Modelo 7,5 $\mathrm{m}^{3}$ & Cilbras \\
Chave Comutadora & Integrada ao protótipo desenvolvido & \\
\hline
\end{tabular}




\subsubsection{Combustíveis utilizados}

Gasolina brasileira comum com 23\% de etanol anidro, Etanol Combustível, GNV e GLP.

\subsubsection{Equipamentos para testes.}

Para analise de emissão de poluentes foi utilizado o analisador TM132 da Tecnomotor (Figura 14) esse equipamento mede a emissão de $\mathrm{CO}$ e HC.

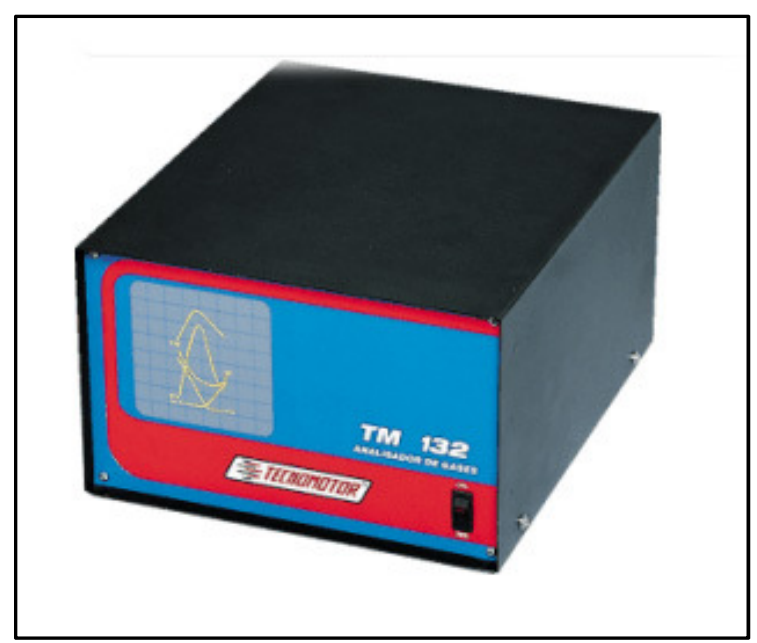

Figura 14 - Analisador de gases TM132 Tecnomotor[33].

Os sinais elétricos do veículo foram medidos através do sofware Labview e um dispositivo de aquisição de dados USB-6009 (Figura 15), ambos da National Instrumets.

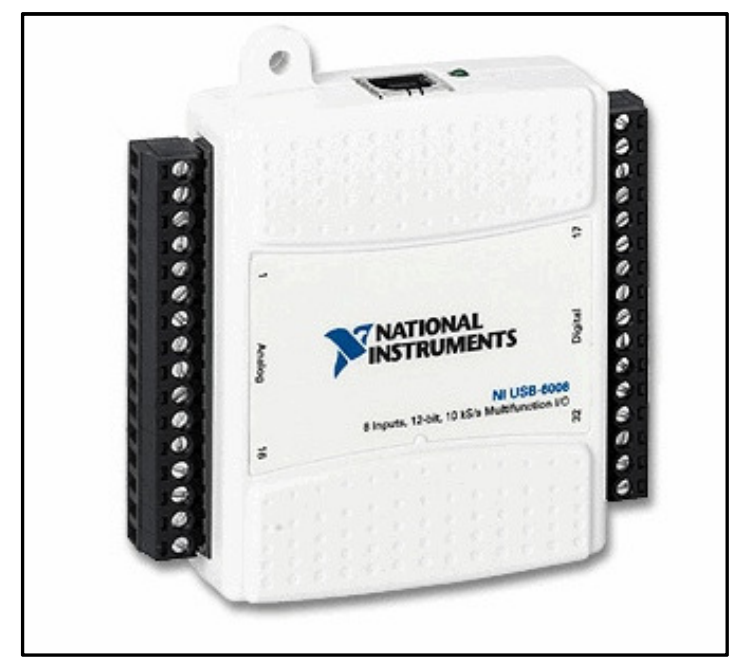

Figura 15 - Dispositivo de aquisição de sinais USB-6009.[33] 


\subsection{SISTEMA DE INJEÇÃO ELETRÔNICA DO PROTÓTIPO}

Nesse capítulo, tem-se a descrição do sistema de controle em malha aberta e fechada, os principais sensores e atuadores utilizados no protótipo.

\subsubsection{Sistema de controle em malha aberta}

O sistema de controle em malha aberta possui sinais de controle pré-determinados. Em um sistema de injeção eletrônica em malha aberta, os sinais obtidos são usados para determinar os sinais de saída. Nesse sistema não é feito nenhum acompanhamento sobre a evolução desse processo. Em um motor, é preciso estabelecer a quantidade de ar admitida através de alguns dados como a rotação, pressão no coletor de admissão, temperatura do ar, temperatura do motor e pressão atmosférica, entre outros. Através desses dados, estima-se a quantidade de ar admitida e através de cálculos pré-determinados, é estimada a quantidade de combustível a ser injetado.

O sistema não promove correções para se adaptar às variações externas como as alterações na qualidade de combustível ou mesmo mistura dos combustíveis. Os primeiros sistemas de injeção eletrônica e a maioria dos sistemas de conversão para GNV utilizam o controle de malha aberta. Na Figura 16 tem-se um esquema de um sistema de controle em malha aberta, sinais de controle são utilizados no processo gerando uma saida, essa saida não é verificada em nenhum momento.

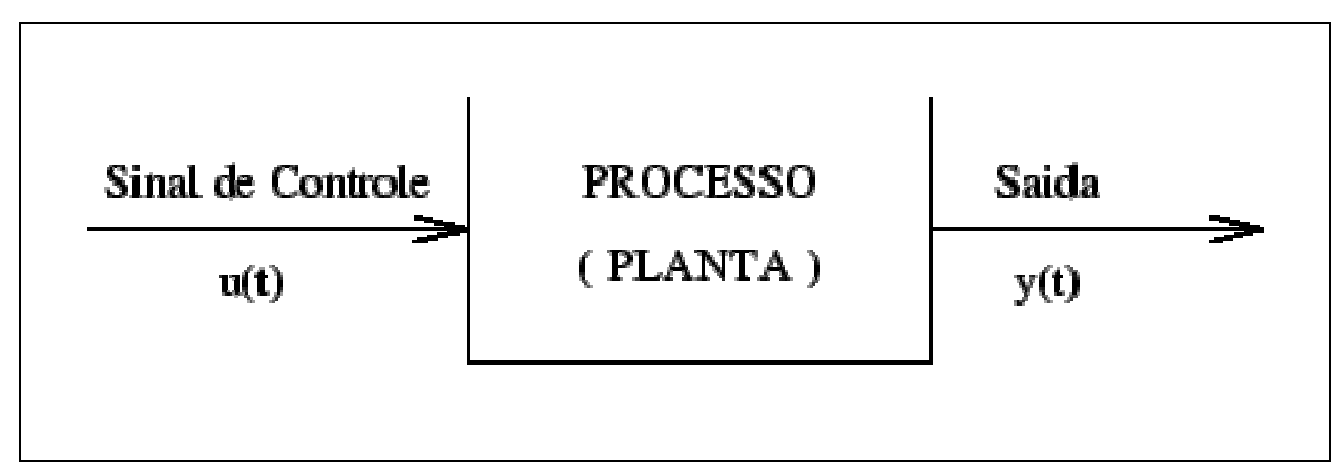

Figura 16 - Controle em malha aberta[35]. 


\subsubsection{Sistema de controle em malha fechada}

No sistema de controle em malha fechada, o sistema é verificado através de sensores que realimentam o sistema. Um controlador executa o processo através de controles predeterminados, e as correções são feitas através da comparação de um sinal de referência e o sinal obtido na saída do processo.

No sistema de injeção dos veículos, o sensor de oxigênio informa a quantidade de oxigênio presente após a combustão. Através desses dados, é possível determinar incrementos ou decrementos no tempo de injeção para que a mistura fique próxima da ideal. Esse é o principal sistema responsável pelo controle dos veículos flexíveis, pois, para o uso do etanol, é necessário a injeção de uma maior quantidade de combustível. Contudo, os veículos não possuem um sensor de combustível, ficando a cargo de o sistema efetuar as correções através dos dados obtidos por meio do sensor de oxigênio. Na Figura 17, observa-se o esquema onde a linha de realimentação sai do final do processo através do sinal do sensor lambda, e volta ao inicio para ser comparada por um sinal de referência.

Os sistemas injeção que utilizam malha fechada também preveem o uso de malha aberta caso ocorra falha no sensor de oxigênio, e em situações como acelerações e desacelerações, em que a leitura do sensor de oxigênio deve ser desconsiderada por alguns instantes.

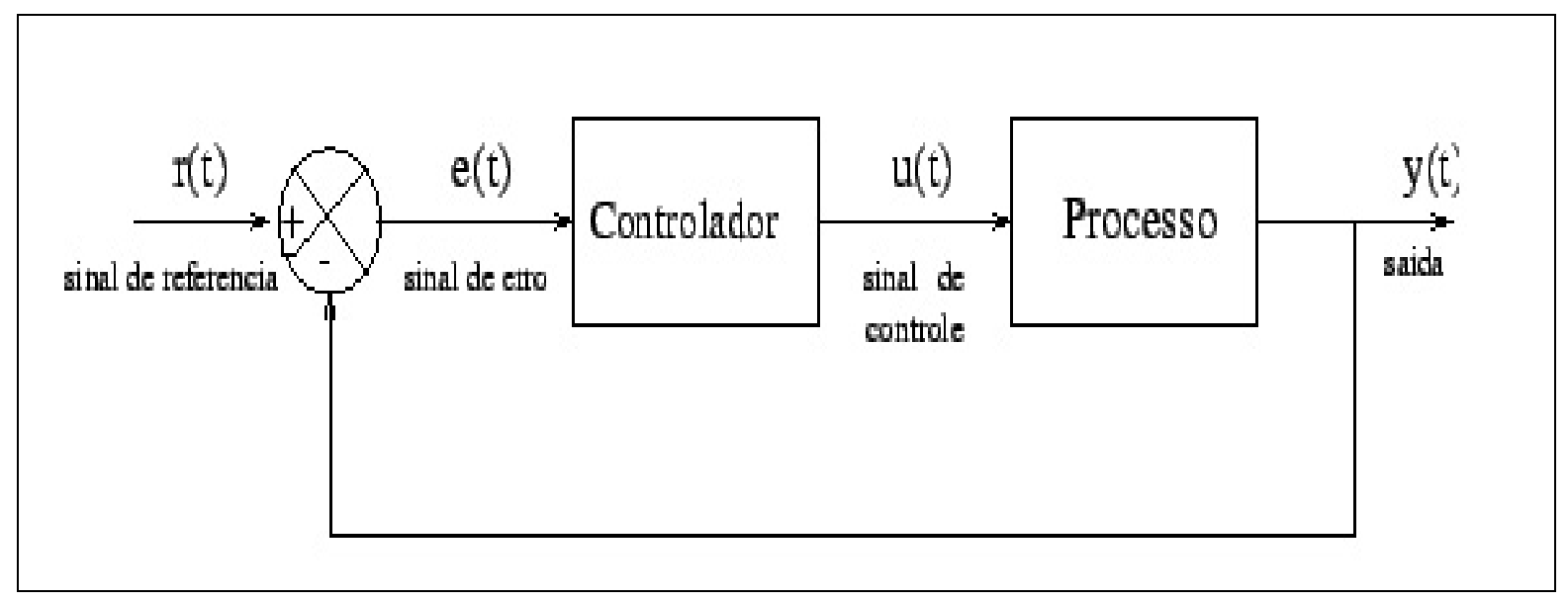

Figura 17 - Controle em malha fechada[35]. 


\subsubsection{Sistema de controle em injeção eletrônica}

Para o desenvolvimento do protótipo, alguns dados do veículo devem ser coletados para a construção da tabela de injeção. A maioria dos sensores utilizados já estão disponíveis no veículo, sendo destacados alguns deles nesse capítulo.

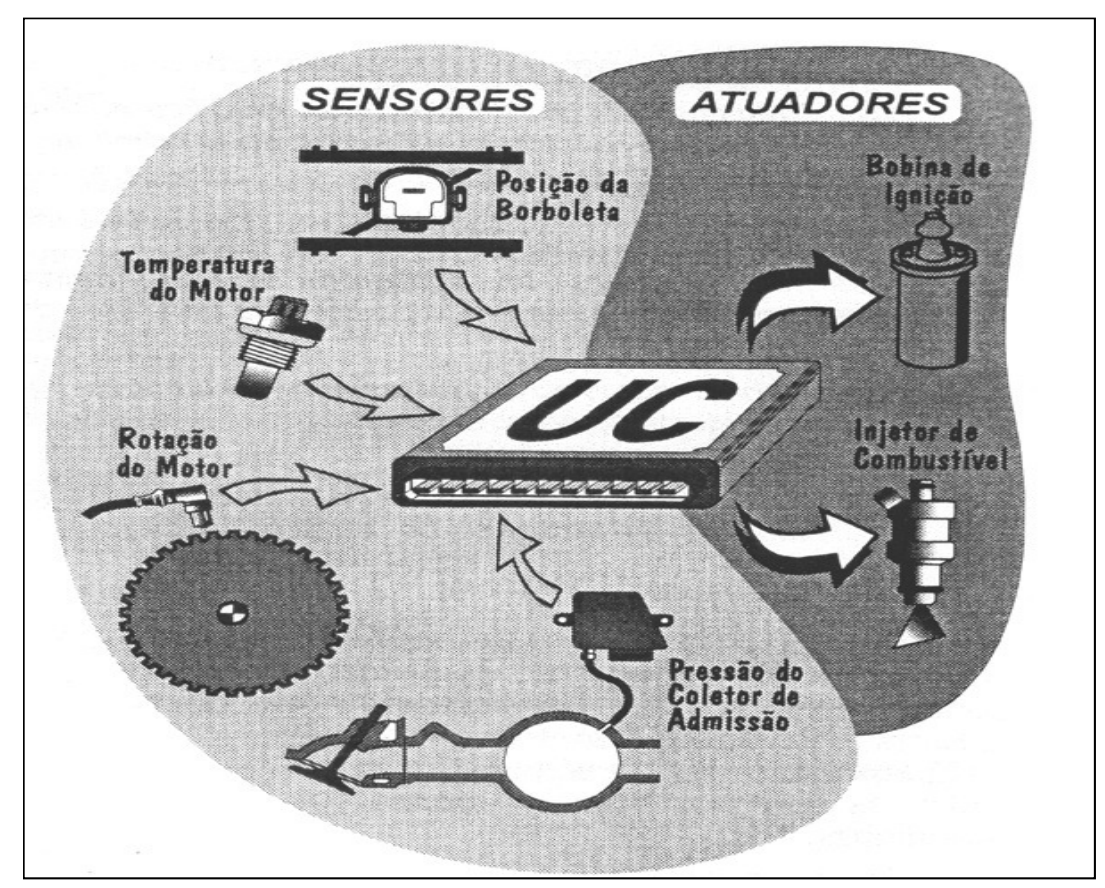

Figura 18 - Sensores e atuadores de uma injeção eletrônica básica[36].

Em um sistema de injeção eletrônica básico, os sensores enviam informação para a unidade de comando, na forma de sinais elétricos. A unidade de comando processa essas informações e aciona os atuadores, onde estes executam os comandos recebidos transformando os sinais elétricos em ações desejadas[36]. Na Figura 18, tem-se os principais sensores e atuadores utilizados em um sistema de injeção básico.

O objetivo principal de um sistema de injeção de combustível é encontrar a estequiometria correta da mistura ar combustível. Através do sensor de massa de ar, associado ao sensor de rotação, tem-se o sinal de entrada, onde é possível calcular a quantidade necessária de combustível, caracterizando esse sistema como malha aberta. Porém, para aumentar a precisão e tornar o sistema flexível, é imprescindível o uso de realimentação com o sistema em malha fechada, onde o principal sensor responsável pela realimentação é o sensor de oxigênio. Todavia, é necessário prever o funcionamento do sistema em malha aberta para que um possível defeito no sensor de oxigênio não interrompa o funcionamento do motor. 
Na Figura 19, é apresentado o exemplo de um mapa de injeção, onde as variáveis principais, carga e rotação, são lidas pelo controlador. A carga é dada pela pressão no pedal do acelerador, que dependendo do veículo, pode ser obtida pelo sensor de posição de borboleta ou pelo sensor de posição do pedal. Com essas duas variáveis, obtêm-se um valor de tempo de injeção, geralmente através de uma tabela. Esse tempo sofre incrementos ou decrementos, calculados através de outros dados, dentre eles, a temperatura do ar, pressão no coletor e correção do fator lambda.

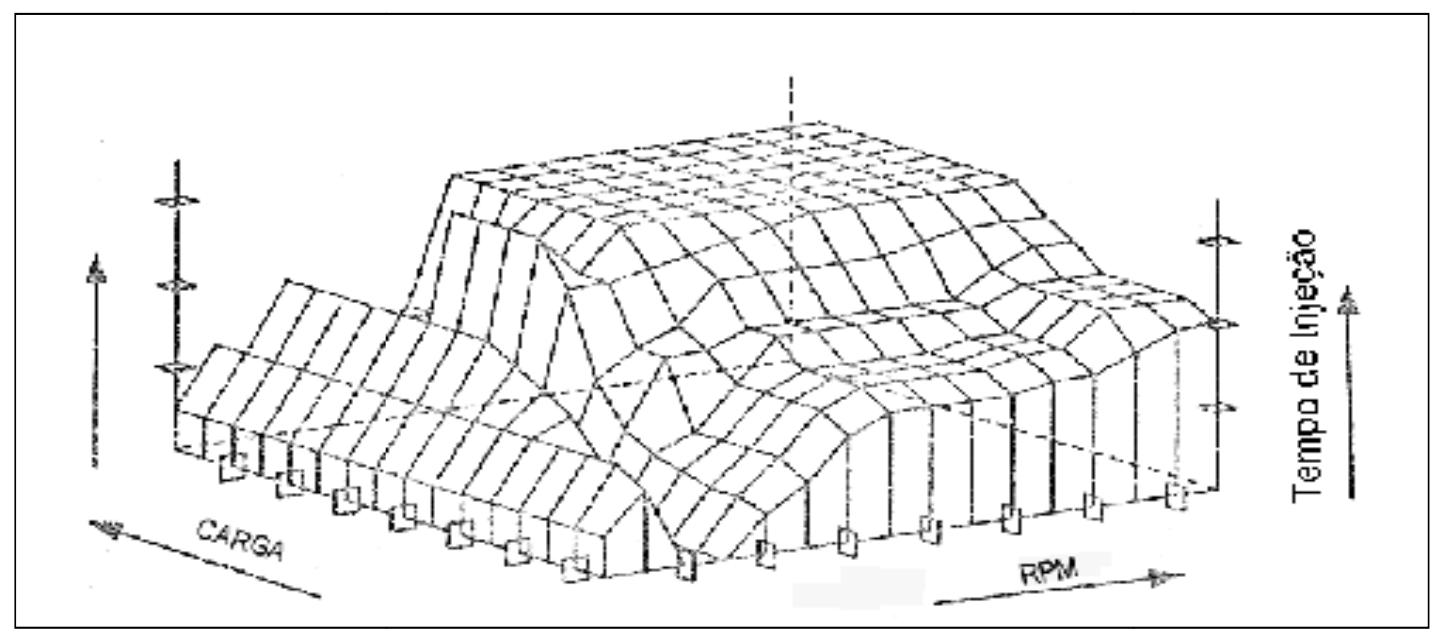

Figura 19 - Mapa de Injeção[37].

\subsubsection{Sensor de oxigênio ou Sonda Lambda}

O sensor de oxigênio, ou sonda lambda, é composto internamente por um elemento cerâmico envolto por um cilindro (eletrodo negativo) e por um cone concêntrico (eletrodo positivo).

$\mathrm{O}$ elemento cerâmico é composto de dióxido de zircônio $\left(\mathrm{ZrO}_{2}\right)$, recoberto por uma fina camada de platina. Um dos lados do elemento cerâmico fica em contato com o ar atmosférico, que possui $21 \%$ de oxigênio, e o outro é exposto aos gases de combustão, onde a concentração de oxigênio é variável em função da realção ar-combustível.

Em temperaturas superiores a $300^{\circ} \mathrm{C}$, o elemento cerâmico torna-se condutor de íons de oxigênio, gerando uma diferença de potêncial proporcional à quantidade de oxigênio, gerando uma medida continua do teor de oxigênio no gás de escape. Com essa informação, é possível saber se a mistura está com excesso de oxigênio (mistura pobre), para tensão de 0 até $400 \mathrm{mV}$, 
ou falta de oxigênio (mistura rica), para tensão de $700 \mathrm{mV}$ a $1000 \mathrm{mV}$. Seu uso é imprescindível para manter a estequiometria da mistura, principalmente em veículos bicombustível.

Essa estequiometria é importante para manter uma boa dirigibilidade, economia e redução da emissão de poluentes, uma vez que o catalisador responsável em converter os gases de escape em gases menos nocivos só funciona corretamente se a estequiometria estiver dentro de uma estreita faixa, próxima ao ponto estequiométrico, o fator lambda, ou $\lambda=1$ [38].

$\mathrm{Na}$ Figura 20, tem-se a imagem do sensor de oxigênio e, na Figura 21, o exemplo de instalação mostrando o sensor na saída do escapamento do motor.

Seu funcionamento só ocorre corretamente em temperaturas acima de $300^{\circ} \mathrm{C}$. Por esse motivo, os modelos mais recentes possuem uma resistência de aquecimento para que sua leitura seja correta logo após a ignição do motor.

No veículo de teste, Daewoo Lanos, a sonda utilizada não possui aquecimento. O sistema só pode fazer a leitura da sonda após o motor aquecido, para garantir que o escapamento já tenha atingido a temperatura ideal. Nesse momento inicial, o sistema trabalha em malha aberta, sem realimentação. No segundo veículo de teste, o Gol, a sonda lambda possui resistência de aquecimento, sendo possível o uso de malha fechada instantes após a partida do motor.

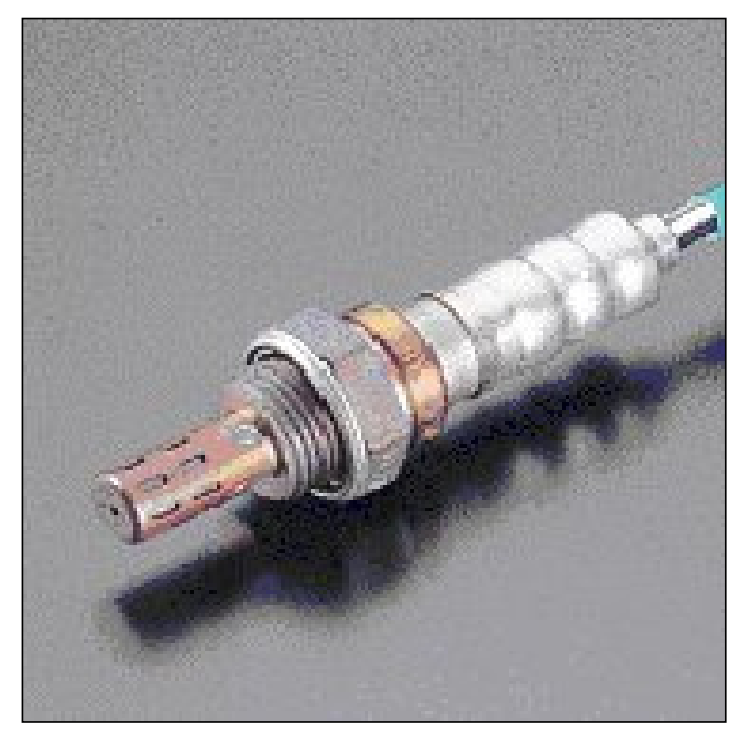

Figura 20 - Sensor de Oxigênio[38]. 


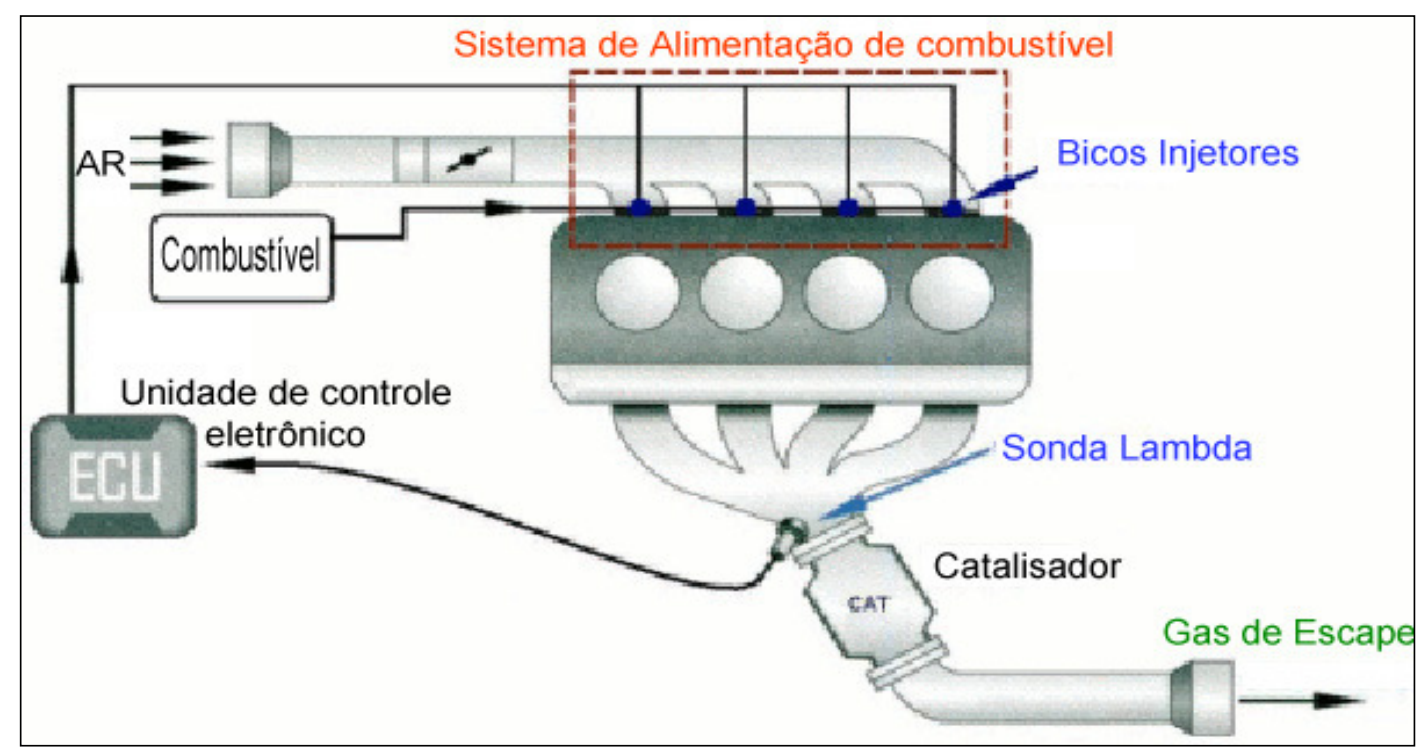

Figura 21 - Sensor de oxigênio e sua instalação[38].

\subsubsection{Sensor de rotação}

O sensor de rotação do motor é um sensor de relutância magnética que envia um sinal pulsado, cuja freqüência é proporcional à velocidade de rotação do motor por minuto (rpm)[29]. O sensor é um gerador de pulsos montado na base do distribuidor ou junto com uma roda dentada no eixo do virabrequim, conforme Figura 22.

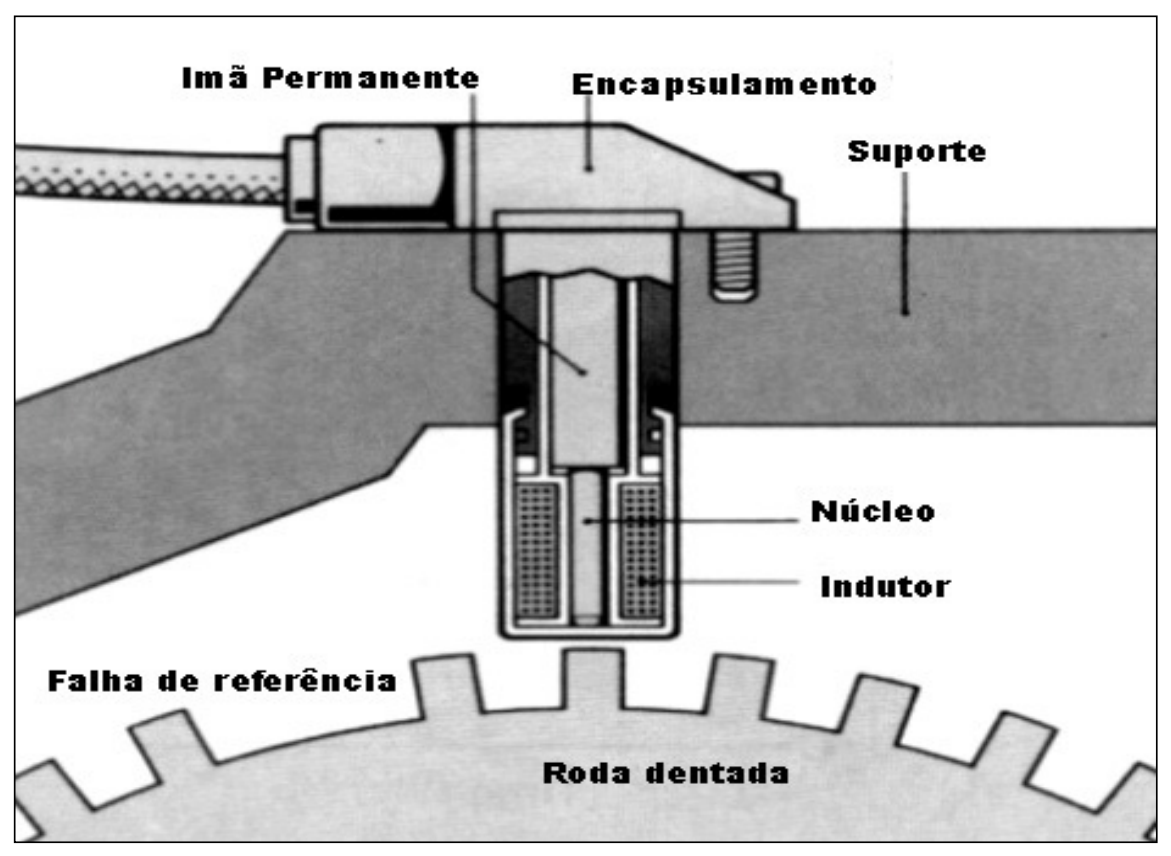

Figura 22 - Sensor de rotação [39]. 
A cada ciclo completo do motor, a roda dentada percorre duas voltas. Sendo assim, é possível determinar a posição no cilindro, porém não é possível determinar sua fase. Alguns veículos não utilizam a fase, tornando a injeção semi-sequencial, com injeção simultânea em dois cilindros. Outros veículos possuem um sensor de fase sendo possível uma injeção sequencial e independente em cada cilindro.

\subsubsection{Medição de massa de ar}

Os sensores de rotação e oxigênio têm funcionamento semelhante na maioria dos veículos. $\mathrm{O}$ mesmo não ocorre com a medição de massa de ar, onde tem-se um ou mais sensores que possibilitam o cálculo da massa de ar.

Para o cálculo da quantidade de combustível a ser injetado, um dos principais parâmetros é a quantidade de massa de ar admitido.

A massa de ar não é obtida diretamente, e sim calculada através de alguns parâmetros, como mostra a eq.(7)[36].

$$
\text { Massa }_{\text {de ar }}=\left(\text { Volume }_{\text {admitido }}\right) .\left(\text { Densidade }_{\text {do ar }}\right)
$$

A densidade do ar varia de acordo com a temperatura e a pressão atmosférica. Portando para o cálculo da massa de ar, deve-se obter esses valores.

Outra maneira de medir a massa de ar é atraves do fluxo de ar, onde tem-se o sensor de palhetas ou VAF (Vane Airflow) apresentado na Figura 23, esse sensor mede o fluxo de ar através da inclinação da palheta.

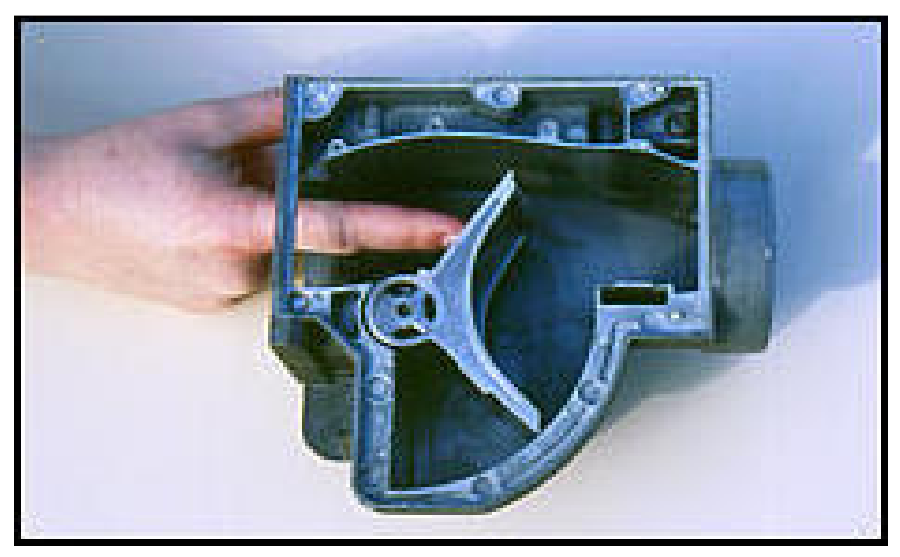

Figura 23 - Sensor de fluxo (VAF)[40]. 
O método mais comum para medição da massa de ar é o sensor de pressão absoluta no coletor ou MAP (manifold absolute pressure), apresentado na Figura 24.

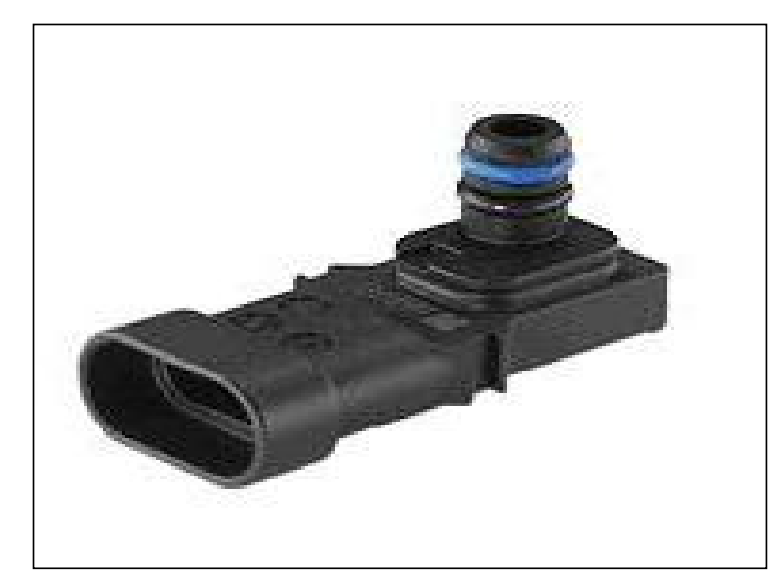

Figura 24 - Sensor MAP[41].

Este sensor é instalado no coletor de admissão e tem a mesma função do sensor de palheta (VAF) fornecendo o fluxo de ar, nesse caso através da pressão no coletor. Em alguns veículos, esse sensor fornece a pressão atmosférica antes do início do funcionamento do motor. [41]

O volume obtido para um valor ideal é apresentado na eq.(8).

$$
\text { Volume }=\frac{\text { rpm }}{2(\text { Cilindrada })}
$$

Para um valor real, utiliza-se o fator de correção da eficiência volumétrica, conforme eq.(9). $\mathrm{Nv}=$ eficiência volumétrica

$$
\text { Volume }=\frac{r p m}{2(\text { Cilindrada }) N v}
$$

Os dois veículos de testes utilizam o sensor MAP para medição da massa de ar.

Existe ainda o método de fio aquecido, MAF (Mass Airflow), sensor de fluxo de massa. Esse é um método direto, pois o sensor já possui um sensor de temperatura incorporado, onde o sinal fornecido é proporcional à massa de ar admitido, sem necessidade de cálculos adicionais. $\mathrm{Na}$ Figura 25, é apresentado um exemplo do sensor MAF. 


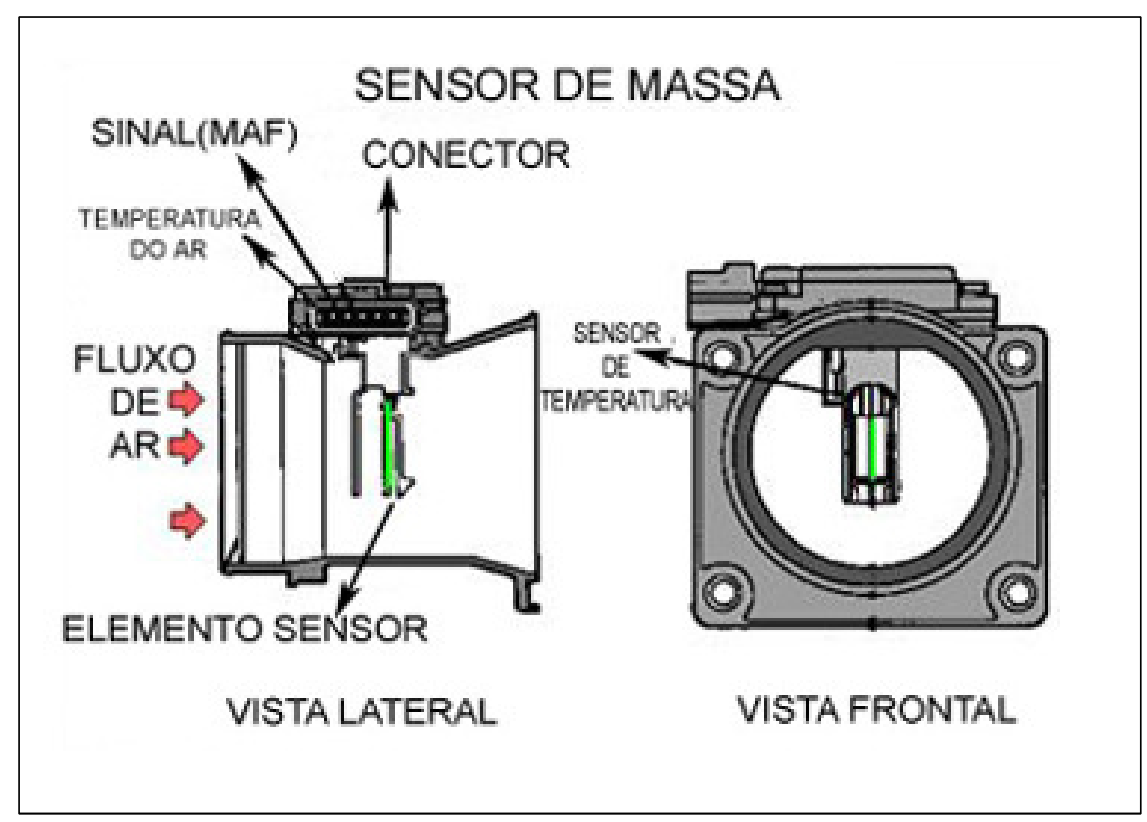

Figura 25 - Sensor de Massa de ar[42].

\subsubsection{Válvula de injeção}

A válvula de injeção, também chamada de bico injetor, é responsável pela injeção do combustível que pode ser feita por uma única válvula (injeção Monoponto), ou por uma válvula por cilindro (injeção Multiponto), que é o caso da maioria dos veículos produzidos atualmente.

Em sistemas de injeção multiponto, cada cilindro possui uma válvula de injeção que pulveriza o combustível. No sistema tricombustível desenvolvido, cada cilindro possui duas válvulas, uma convencional e outra para injeção do GNV. A válvula possui apenas dois estágios, fechado ou aberto, sua vazão é controlada pelo tempo de abertura. Na Figura 26, tem-se um modelo de válvula de injeção da Bosch. Existem vários modelos que se diferem apenas pela vazão e resistência elétrica.

A válvula de injeção é ligada à linha de combustível com pressão constante, a vazão do combustível é controlada pelo tempo de injeção. 


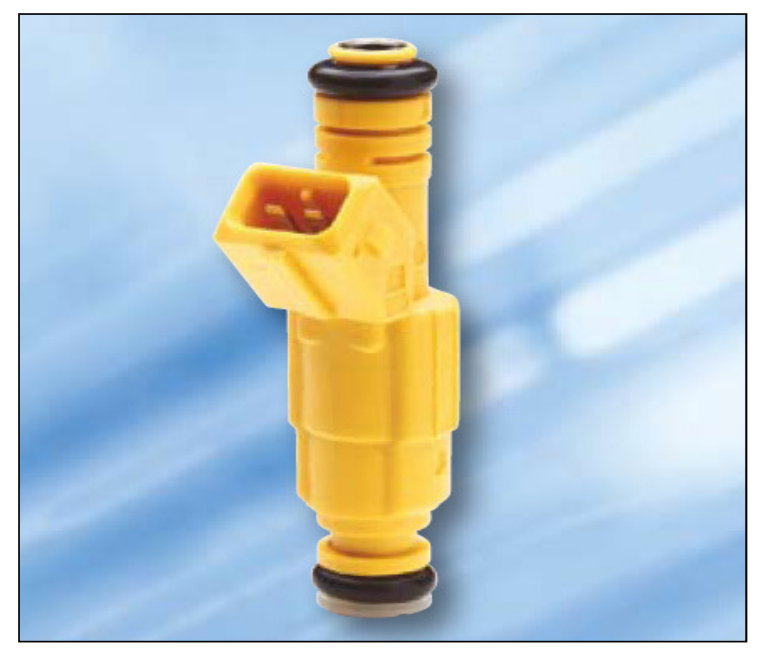

Figura 26 - Válvula de injeção ou bico injetor[29].

\subsubsection{Sensor de baixa pressão de GNV}

O sensor de baixa pressão de GNV é responsável por informar quando a pressão na linha de baixa pressão é inferior à pressão de trabalho de 2 bar. Na Figura 27, tem-se as 4 válvulas injetoras e o sensor de pressão instalado na mesma linha. Nesse ponto, a pressão não sofre grandes variações por estar após o regulador de pressão. Sua leitura é importante, pois é comum o motorista utilizar todo o GNV disponível no cilindro. Quando isso ocorre, o sistema detecta a redução na pressão e faz a troca do combustível, utilizando somente o combustível líquido. Essa troca deve ser feita sem que ocorra falhas, pois caso isso ocorra no momento de uma ultrapassagem, a segurança pode ser comprometida.

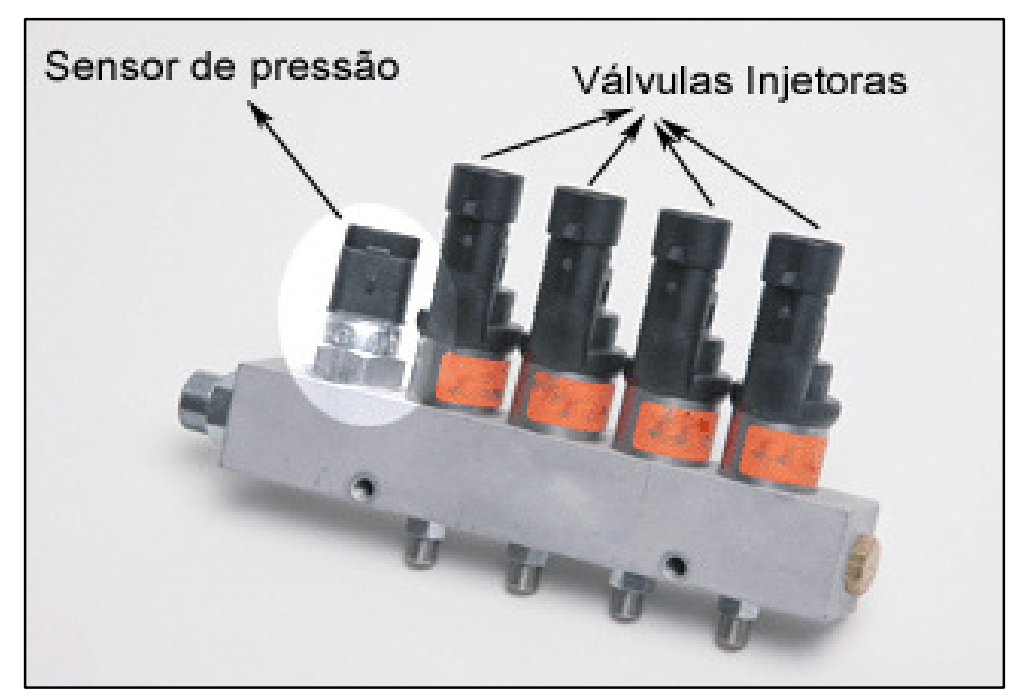

Figura 27 - Sensor de pressão e Válvula Injetora [33]. 
No sistema convencional aspirado, quando combustível chega ao fim, o veículo falha e o motorista faz a troca para o combustível líquido manualmente.

\subsubsection{Sensor de posição do pedal}

A leitura do ângulo do pedal do acelerador é utilizada para determinar a carga solicitada pelo motorista, sendo esse um dos dados responsáveis pelos cálculos das estratégias de economia e potência.

O sensor de posição do pedal é responsável pela medida do ângulo do pedal do acelerador, no Daewoo lanos, o acelerador é ligado diretamente a válvula borboleta por um cabo de aço, na válvula borboleta existe um potênciometro que varia a tensão proporcional ao ângulo do pedal do acelerador, apartir dessa tensão se obtem o ângulo do pedal. O Gol possui acelerador eletrônico, a borboleta é acionada eletronicamente pela ECU, não possuindo cabo ligado ao corpo de borboletas, contudo, o sinal é semelhante, seu pedal possui uma saida analógica cuja tensão é proporcional ao ângulo do pedal do acelerador.

Na Figura 28 é apresentado o pedal do acelerador do Volkswagen Gol. O sinal do pedal varia de 0 a $5 \mathrm{v}$, representando respectivamente, 0 a $100 \%$ do curso do pedal.

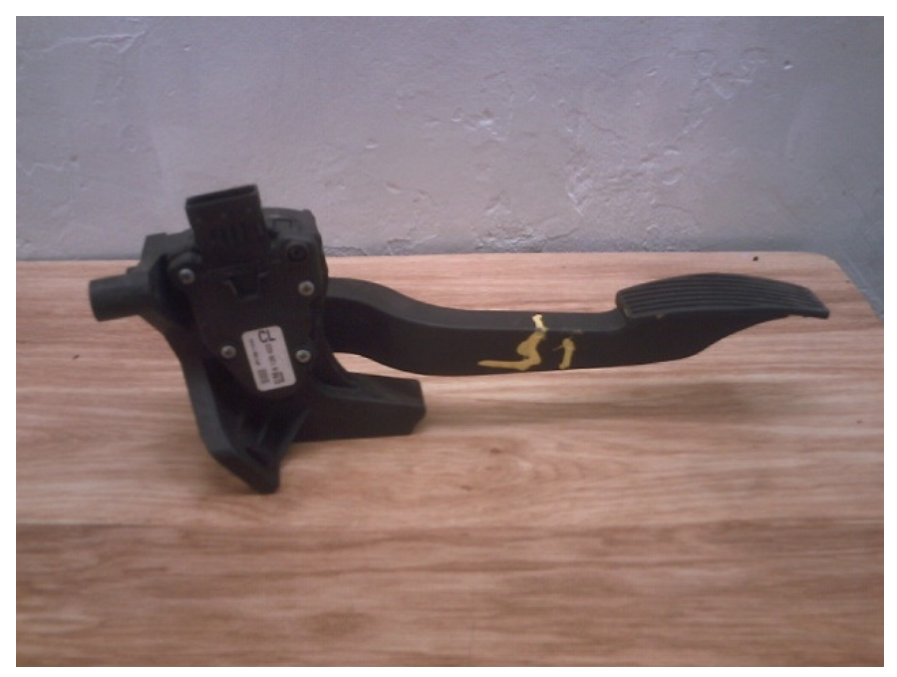

Figura 28 - Pedal do acelerador do Gol[33]. 


\subsection{DISPOSITIVO PROTÓTIPO}

Nesse capítulo, são apresentados detalhes da construção do dispositivo protótipo, a leitura do sensor de oxigênio, a unidade de potência para acionamento dos atuadores e comunicação entre a unidade principal e de potência.

Para o desenvolvimento do dispositivo protótipo, optou-se por separar a parte de potência do circuito da parte de leitura e cálculos, reduzindo a possibilidade de interferências e facilitando o desenvolvimento. O microcontrolador escolhido foi da familia PIC da Microchip, devido ao seu baixo custo, boa disponibilidade no mercado interno e disponibilidade de equipamentos de gravação.

O Pic16F877A foi escolhido para o módulo principal por possuir 8 entradas com conversor analógico para digital (A/D), facilitando e simplificando a leitura dos sensores, pois minimiza os circuitos e ainda possui boa compatibilidade com outros microcontroladores da família PIC de 40 pinos, facilitando sua substituição caso ocorra necessidade de aumento da capacidade de processamento.

Para o módulo de potência, utilizou-se um Pic16f870, destinado ao acionamento dos 9 atuadores existentes.

Para injeção do combustível líquido, foram utilizadas as quatro válvulas injetoras existentes no veículo, e para a injeção do GNV, foram instaladas quatro válvulas injetoras de GNV.

Uma válvula solenoide foi instalada na linha de pressão, antes do redutor de pressão. A válvula é do tipo NF (Normalmente Fechada), fechando a passagem do gás caso a energia seja interrompida, principalmente quando o veículo estiver desligado.

Na figura 22, é apresentado o esquema básico do protótipo do gerenciador tricombustível com injeção positiva, destacando apenas seus atuadores.

Na Figura 30, tem-se o esquema de instalação do gerenciador, com seus atuadores e sensores. A vazão na válvula de injeção é controlada por tempo. A pressão na linha de combustível se mantém constante, tornando possível controlar com precisão a quantidade injetada através do tempo de abertura dessa válvula. Em alguns casos, a pressão na linha de combustível pode ser alterada e uma compensação no tempo de injeção é necessária. 


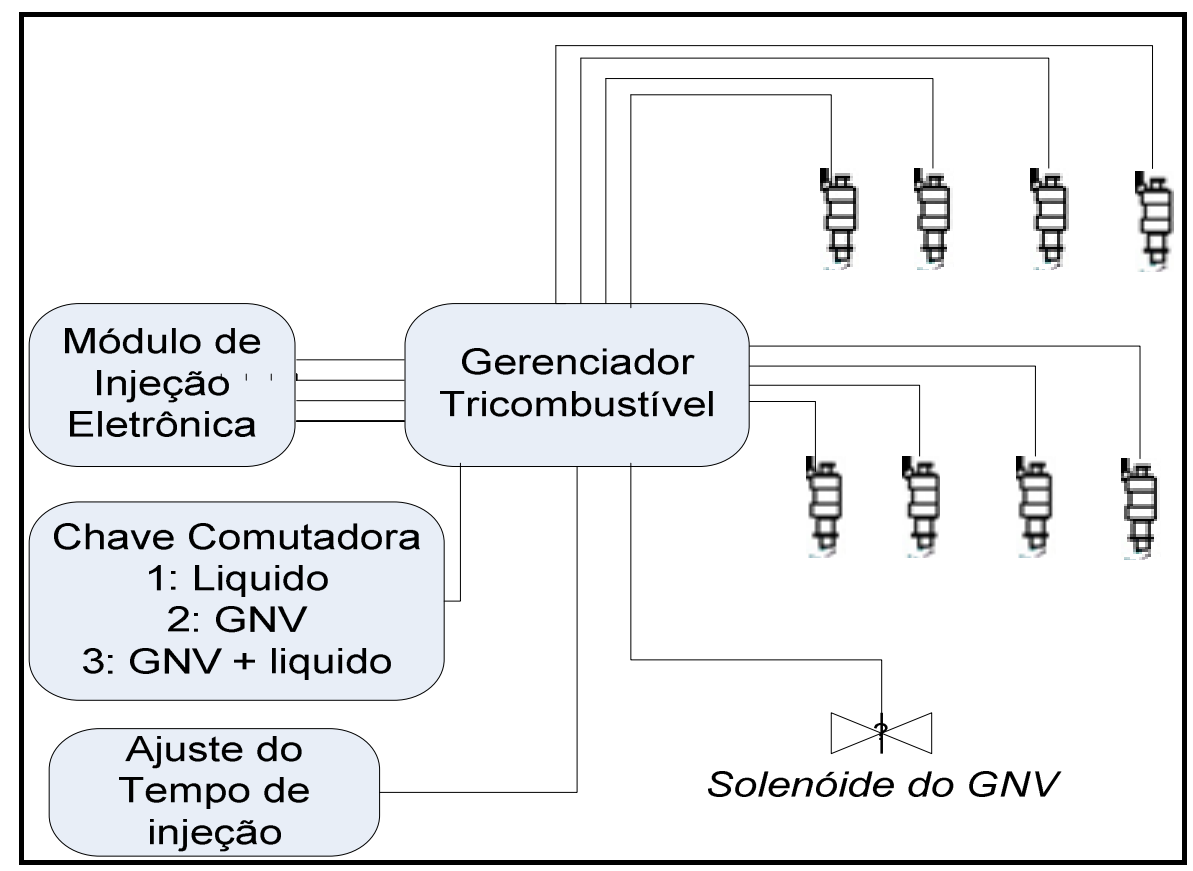

Figura 29- Esquema básico do gerenciador tricombustível e seus atuadores [33].

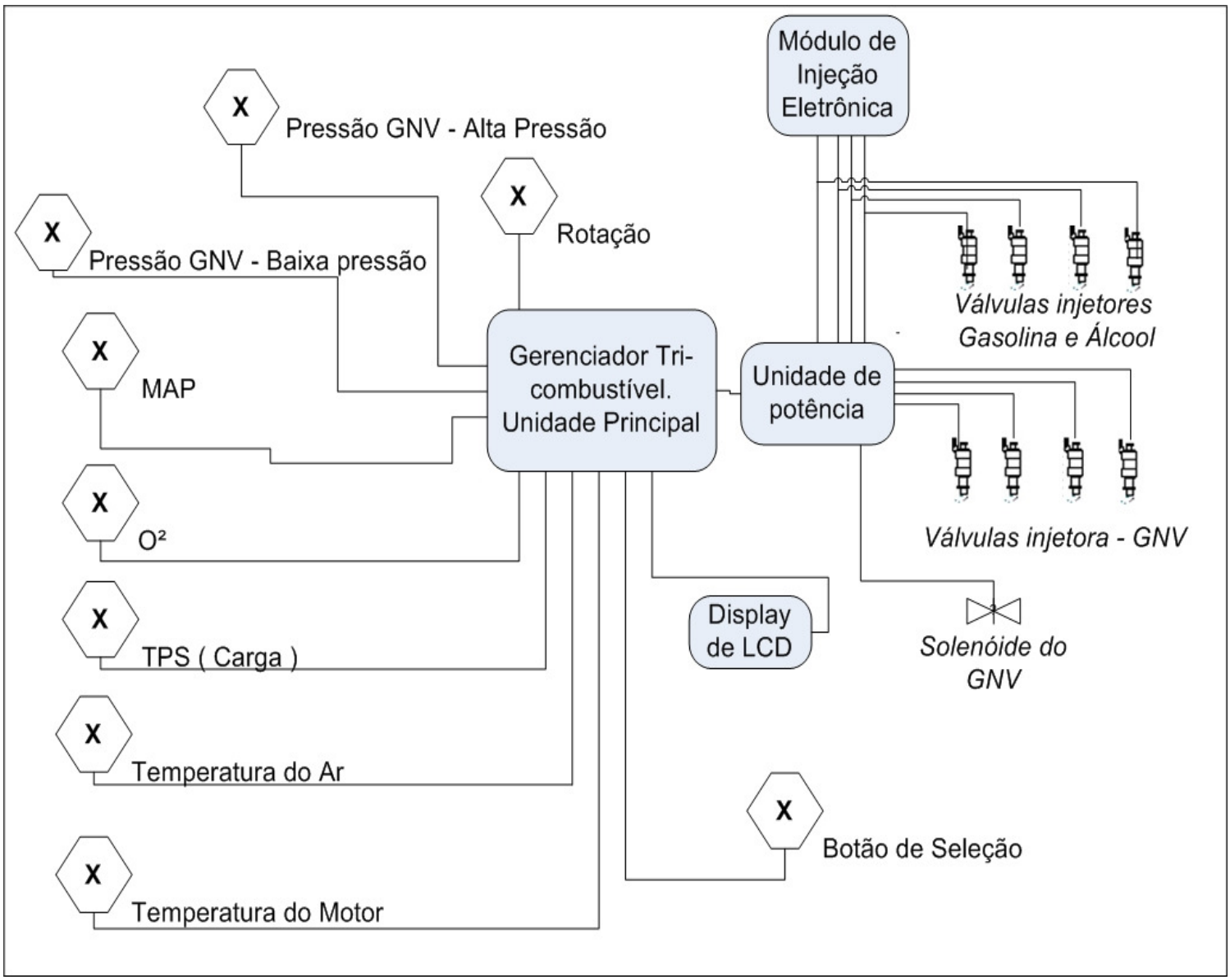

Figura 30 - Esquema do gerenciador tricombustível, atuadores e sensores[33]. 
Na Figura 31, tem-se o esquema de instalação e, na Figura 32, o diagrama esquemático das linhas de combustível independentes.

O GNV é armazenado no cilindro (a) com pressão até 200bar, ligado a uma tubulação de gás de alta pressão (b), passando pela válvula de abastecimento (c) e o solenoide de alta pressão (d) até o redutor de pressão (e). Ao passar pelo redutor, a pressão cai para 2 bar e se mantém estável na linha de baixa pressão (f), onde estão ligadas as válvulas injetoras (g) e o sensor de baixa pressão (h). Ao acionar a válvula injetora, o gás é enviado através de uma tubulação curta (i), cerca de $30 \mathrm{~cm}$ ao coletor de admissão do motor (j), que é instalado próximo da válvula de admissão (k). Outra linha de combustível é a de combustível líquido, etanol e/ou gasolina. O combustível sai do tanque de combustível (l) através da bomba de combustível (m), que possui um regulador de pressão, mantendo a pressão cerca de 3 bar na linha de combustível (n), até os injetores (o), que são instalados diretamente no coletor de admissão (j), próximo à válvula de admissão (k). 


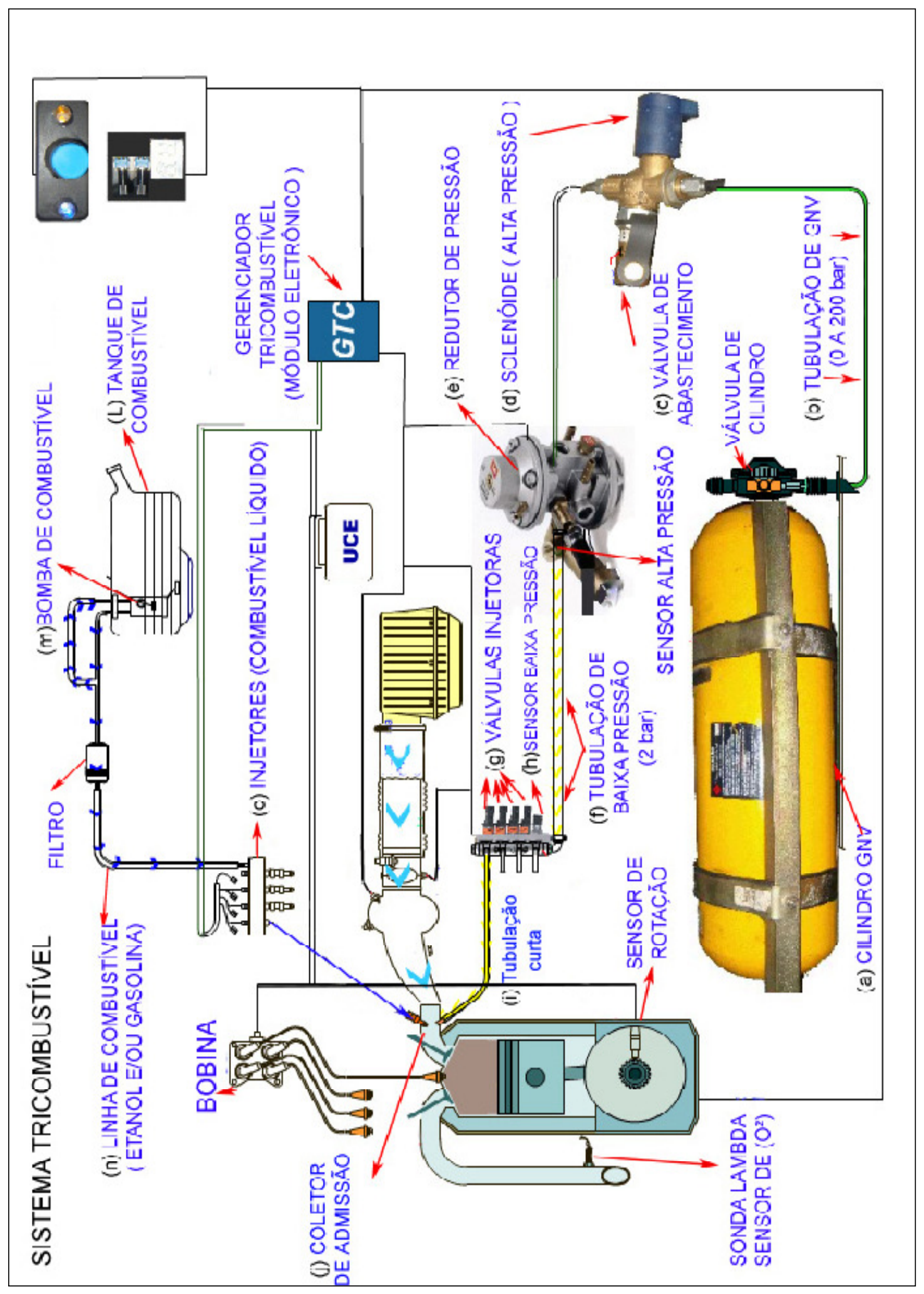

Figura 31 - Disposição esquemática do protótipo do gerenciador tricombustível - pressão positiva[33]. 


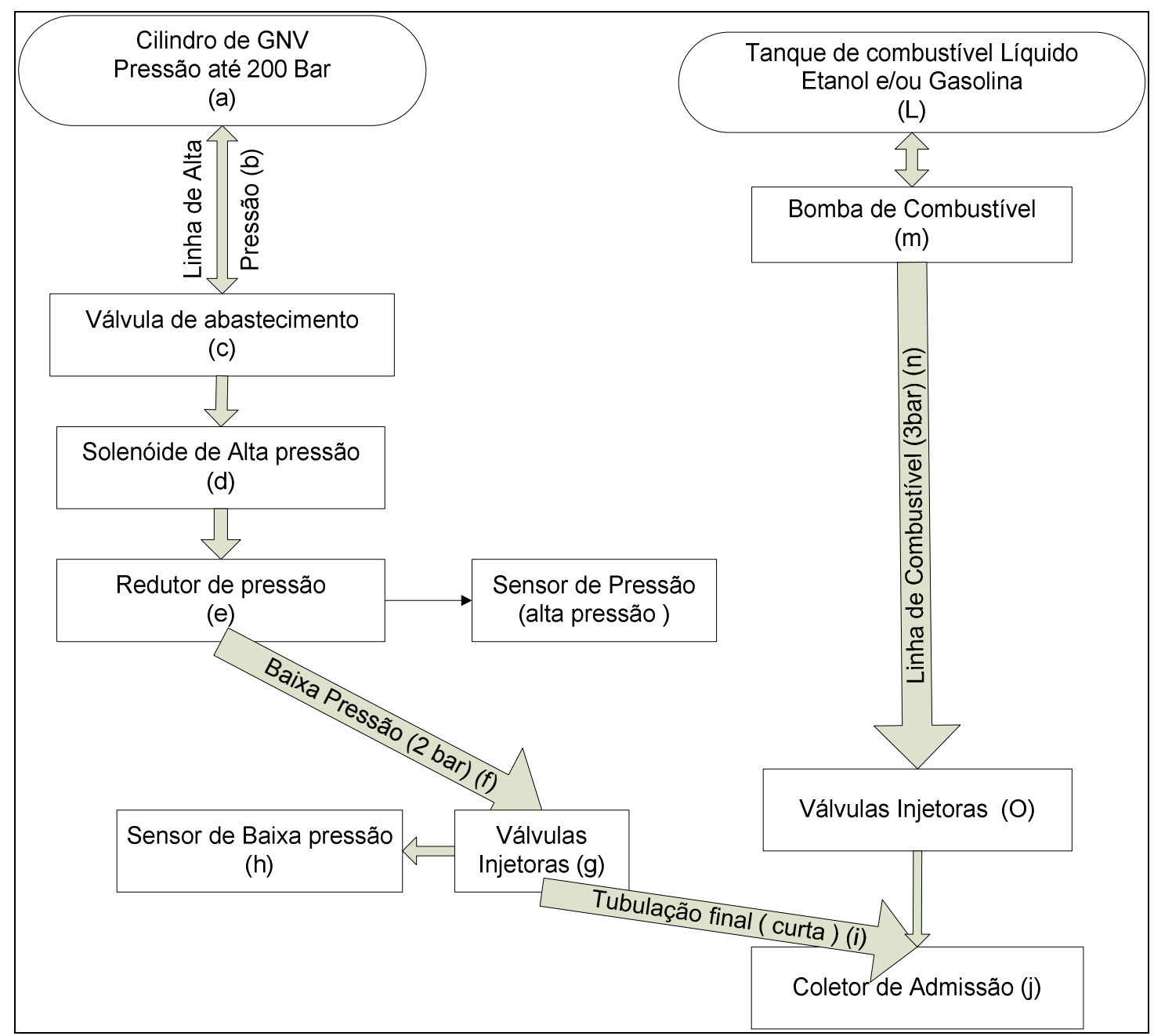

Figura 32 - Diagrama esquemático das linhas de combustíveis [33].

\subsubsection{Circuito e leiaute do gerenciador tricombustível}

Na Figura 33, é apresentado o circuito protótipo. Na placa inferior, está o controlador principal responsável pela leitura dos sensores e os cálculo do tempo de injeção. Na placa superior, estão os transistores de potência para acionamento das válvulas injetoras do combustível líquido e do GNV. 


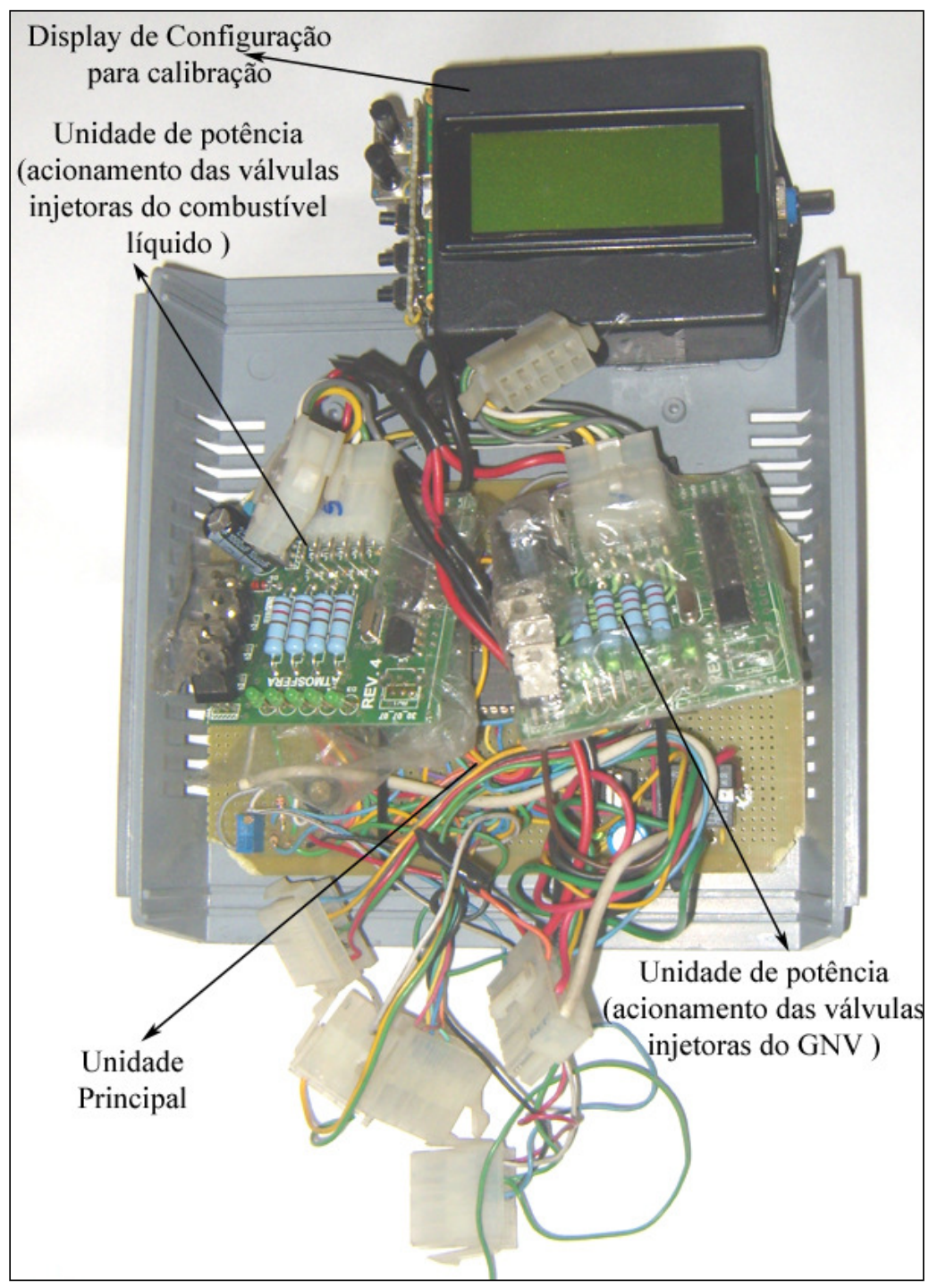

Figura 33 - Circuito protótipo do gerenciador tricombustível com injeção positiva de GNV[33].

\subsubsection{Unidade principal}

Na unidade principal estão as entradas dos sensores, uma saída para comunicação serial e paralela. Foram inseridos alguns componentes adicionais para deixar disponíveis entradas analógicas, utilizando um amplificador operacional e saídas de potência, utilizando 4 transistores FET IRFZ44N. Esses itens foram incluídos para que já estejam disponíveis para uso, caso necessite de leitura de sensores e/ou acionamento de atuadores adicionais. Na Figura 34, é apresentado o protótipo da unidade principal, na Figura 35, o leiaute do circuito em dupla face e na Figura 36, a imagem de simulação em 3D da placa da unidade principal. 


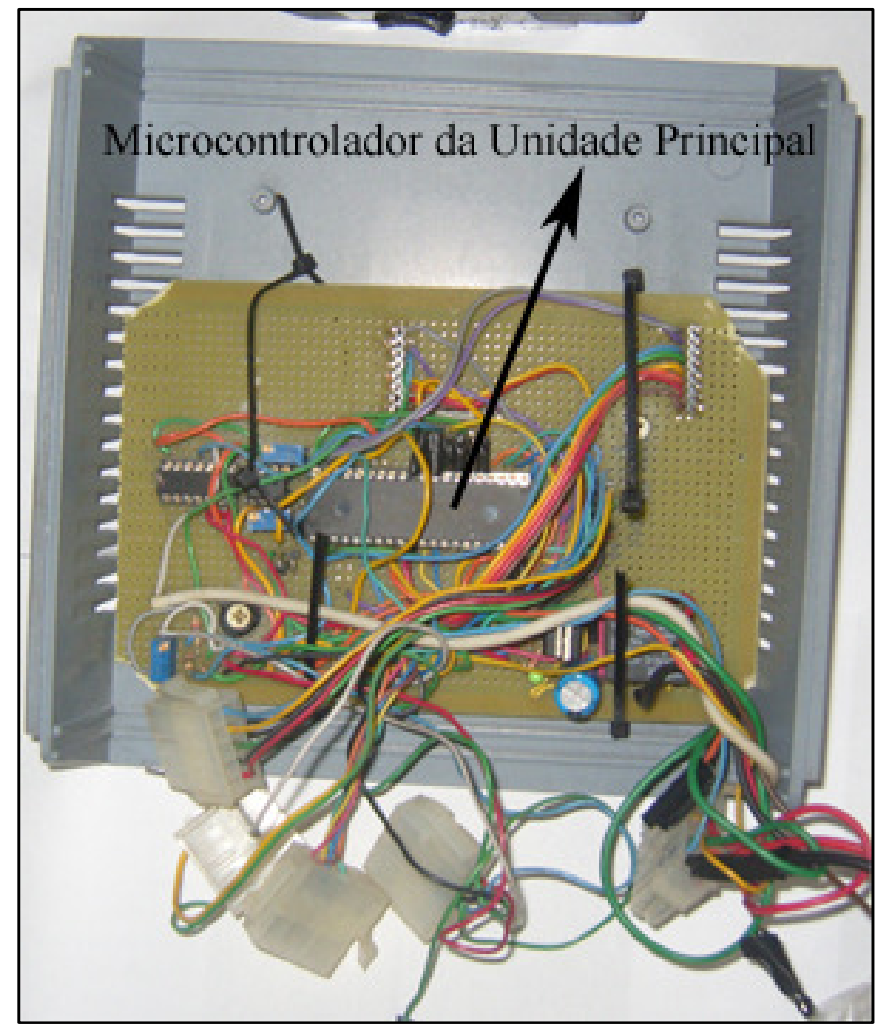

Figura 34 - Protótipo da Unidade Principal[33].

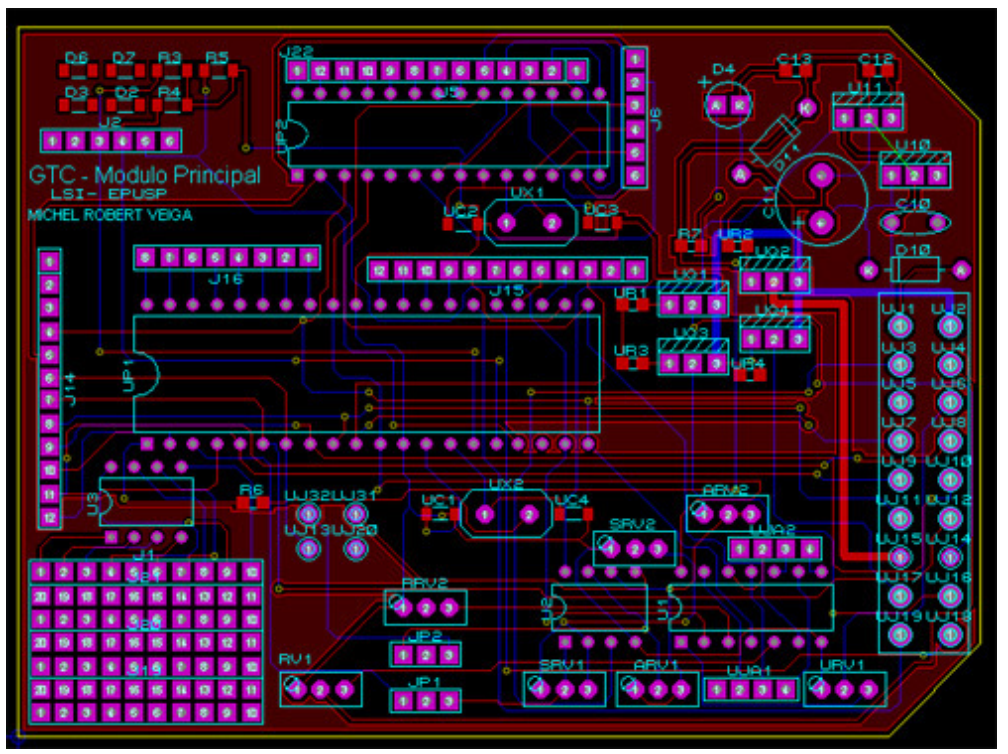

Figura 35 - Leiaute do Circuito da placa principal[43]. 


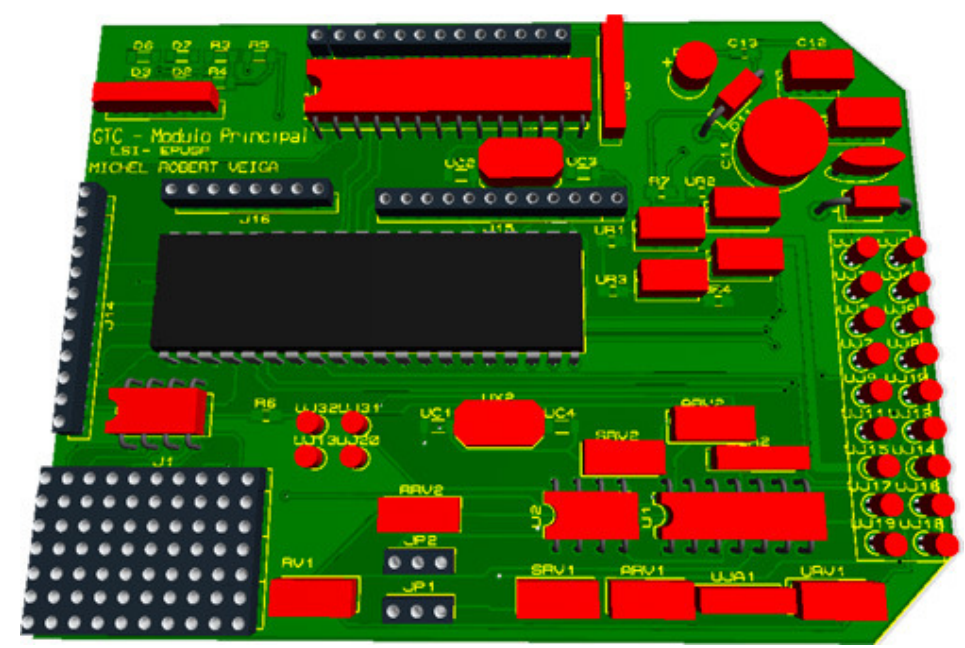

Figura 36 - Simulação em 3D da placa de circuito impresso da unidade principal[43].

\subsubsection{Sensor de oxigênio ou sonda lambda}

O sensor de oxigênio, ou sonda lambda, conforme exemplo no item 3.2.4, tem a característica de variar sua tensão de 0 a 1 Volt, inversamente proporcional à quantidade de oxigênio. Esse sinal analógico deve ser convertido por uma entrada analógica disponível no microcontrolador Pic18f877, utilizado na unidade principal. O conversor já disponível no PIC possui leitura máxima de 10 bits, com tensão entre de 0 a 5V. Para utilizar toda a escala de conversão do PIC, é necessária uma amplificação de 5 vezes, obtida através do amplificador operacional LM358, como mostra a Figura 37.

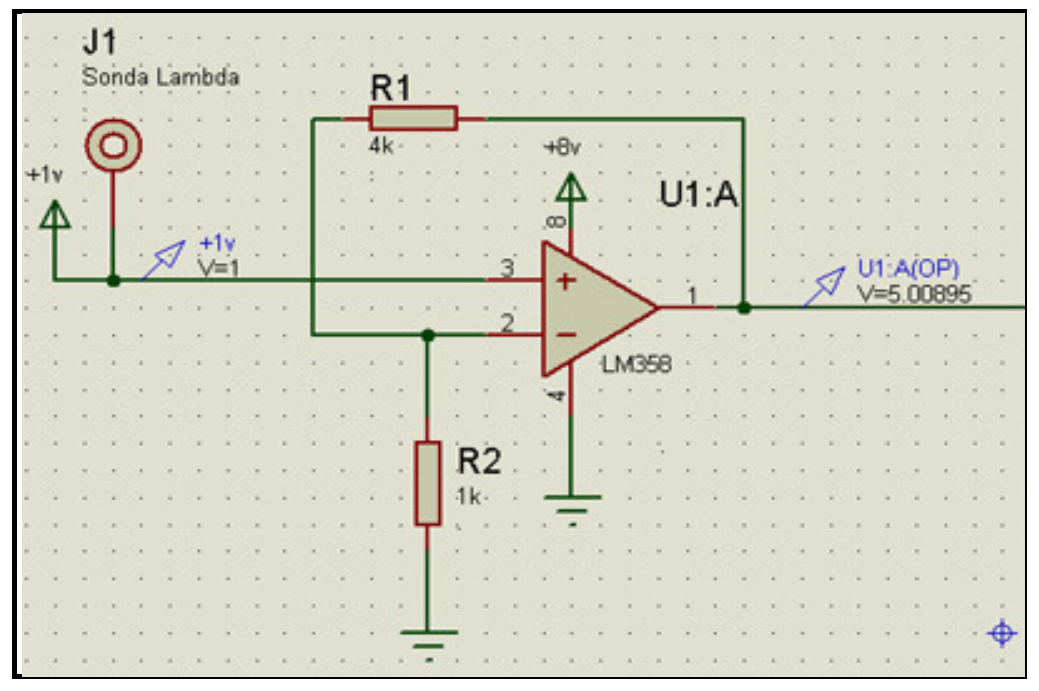

Figura 37 - Circuito Amplificador para o sinal da sonda lambda[43]. 
Para estabelecer o ganho utilizando o LM358, é necessário o uso de dois resistores, obedecendo à eq.(10).[44]

$$
\frac{(R 1+R 2)}{R 2}=\text { Ganho }
$$

Para ganho=5 utiliza-se a eq.(11) abaixo:

$$
\frac{(R 1+R 2)}{R 2}=5
$$

Simplificando, tem-se a eq.(12)

$$
(R 1+R 2)=5 R 2 \quad \text { Portando } R 1=4 R 2
$$

O resistor R2 deve ser quatro vezes menor que R1, sendo escolhido o valor de 1 kohm para R2 e 4kohm para R1.

Após amplificação, o sinal lido pelo microcontrolador varia de 0 a 5 Volts, proporcionando uma leitura de 10 bits.

\subsubsection{Sensor de rotação}

Detalhes do sensor de rotação foram apresentados no item 3.2.5. Nesse capítulo, são apresentados os detalhes do funcionamento do sensor no protótipo desenvolvido.

O motor completa um ciclo após dois giros da roda dentada. Através da leitura da roda dentada, é possível determinar a velocidade de rotação do motor e qual a posição de cada cilindro. Porém, não é possível determinar sua fase. No Daewoo Lanos, a fase não é determinada e o sistema trabalha com injeção semi-sequencial, onde duas válvulas injetoras são acionadas simultaneamente, sendo que um cilindro está na fase de admissão e o outro esta fase de escape com a válvula de admissão fechada.

No VW Gol, a injeção é sequencial. Cada válvula injetora é acionada de forma idependende , isso só é possível pois o veículo possui um sensor de rotação em sua roda dentada e um outro 
sensor para determinar a fase.

Para um correto condicionamento do sinal, foi utilizado um inversor Schmitt Trigger, devido à capacidade deste de condicionar o sinal dentro da faixa de operação do controlador e eliminar ruídos. Esse circuito elimina os ruídos pois, quando a tensão de entrada é maior que um limiar escolhido, a saida é acionada em nível alto, que, no caso do CI utilizado, é de 5V. Na Figura 38, tem-se um exemplo do sinal de entrada Vi e o sinal de Saida Vo. Quando o sinal de entrada está acima do limiar VH, o sinal de saída fica em nível baixo, com tensão de 0 . Quando está abaixo desse limiar, o sinal de saída está em nivel alto (5V). A eliminação do ruído ocorre, pois quando o sinal de entrada oscila dentro desse limiar, o sinal de saida é mantido.

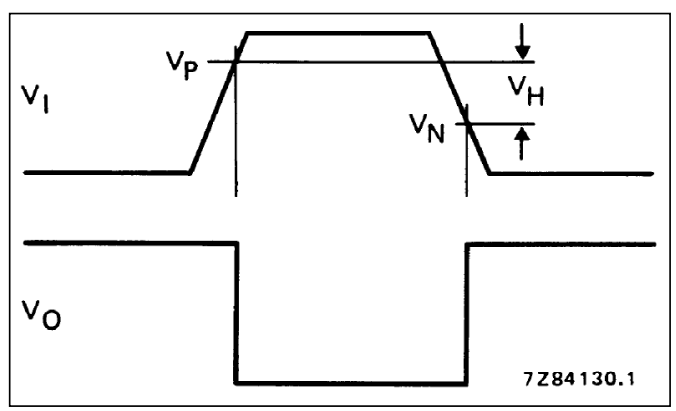

Figura 38 - Sinal de entrada e saída do CI40106BP[45].

O Circuito Integrado (CI) utilizado que possui essa característica é o HFE40106B. Na Figura 39, é apresentado o esquema de ligação.

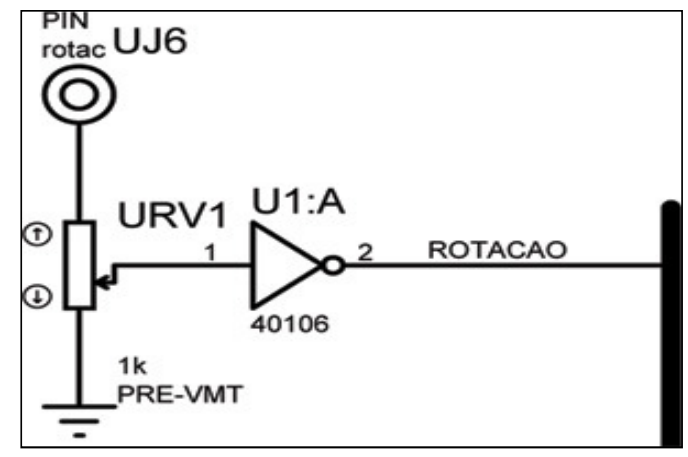

Figura 39 - Filtro do sinal de rotação[43].

Na Figura 40, é apresentado o gráfico do sinal de rotação sem o filtro, onde se observa uma variação de tensão de $-12 \mathrm{~V}$ a $+12 \mathrm{~V}$. Esse sinal, ao passar pelo circuito com o CI HFE40106, 
foi condicionado a níveis bem definidos, onde o nível alto ficou em 3,5V e nível baixo em 0,5V, conforme observado na Figura 41. Estes valores são ideais para que o microcontrolador interprete como nível alto e baixo e possa fazer a contagem dos pulsos, determinando a velocidade de rotação.

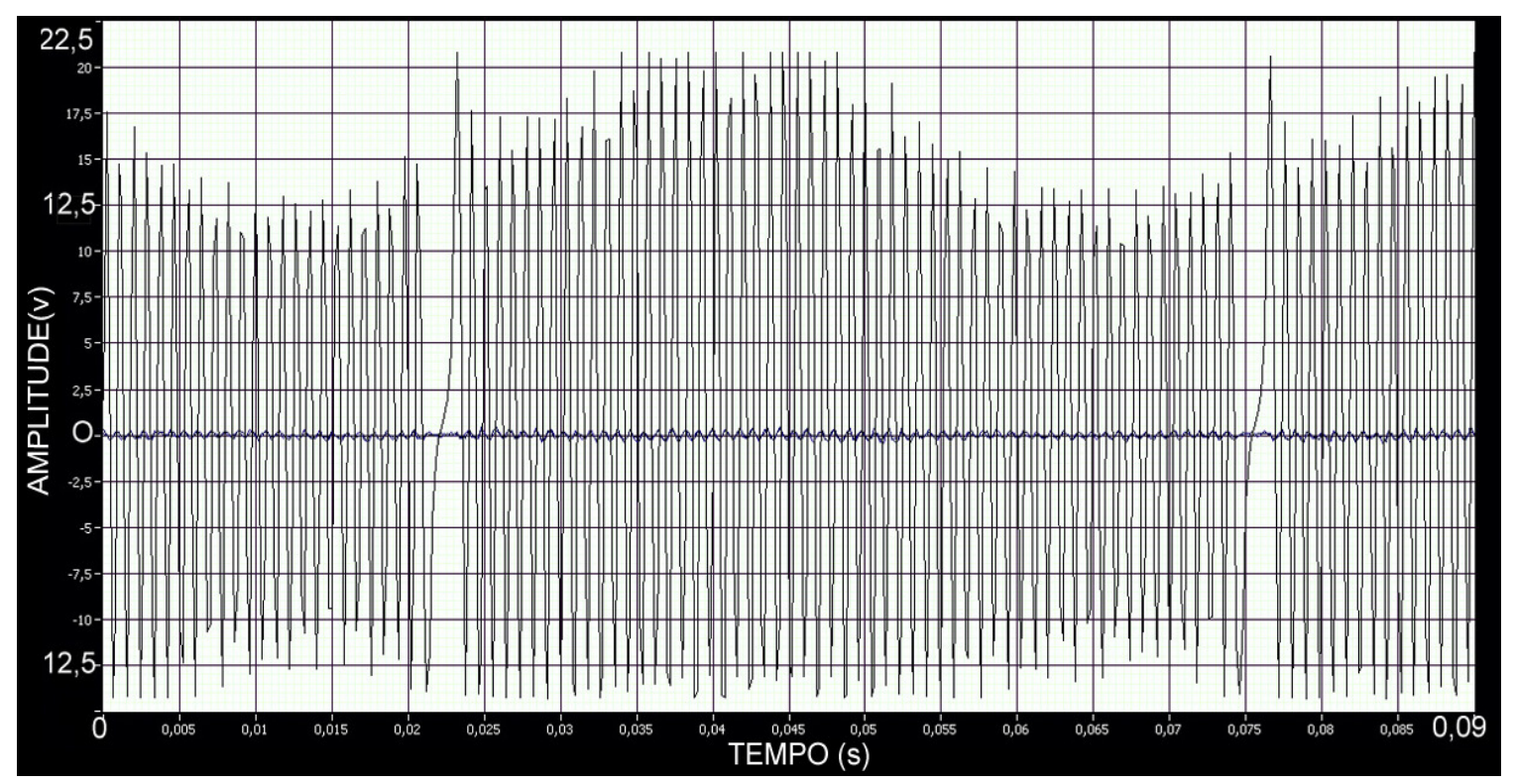

Figura 40 - Gráfico do sinal de rotação sem filtro[33].

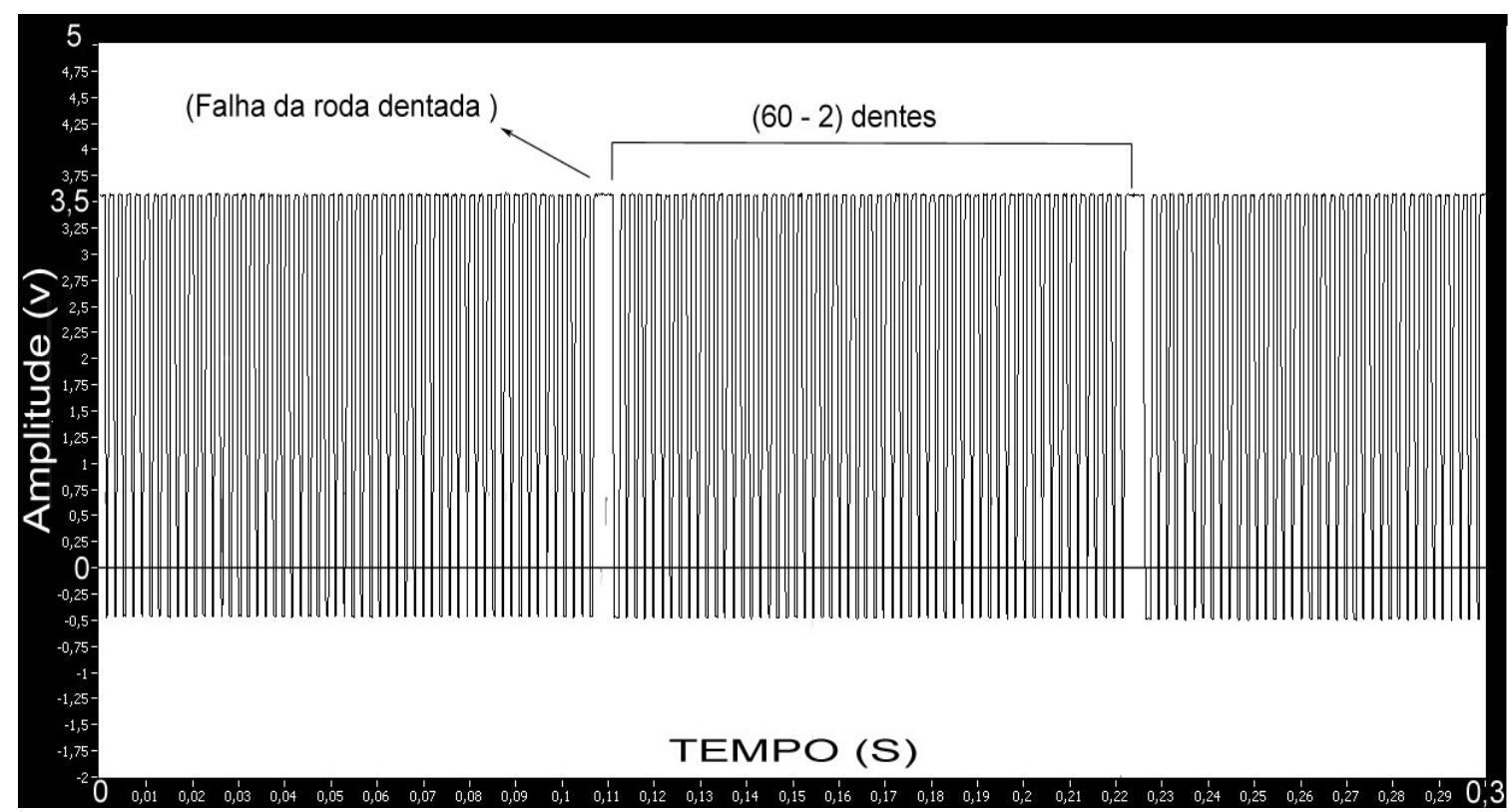

Figura 41 - Sinal de rotação após filtro[33]. 


\subsubsection{Unidade de potência}

A unidade de potência possui um controlador pic16f870, responsável por receber os dados enviados pela unidade principal e efetuar o acionamento das válvulas injetoras através dos transistores IRFZ44N.

Na Figura 42, tem-se o leiaute do Circuito da unidade de potência e, na Figura 43, a imagem simulada em 3D da placa de circuito impresso.

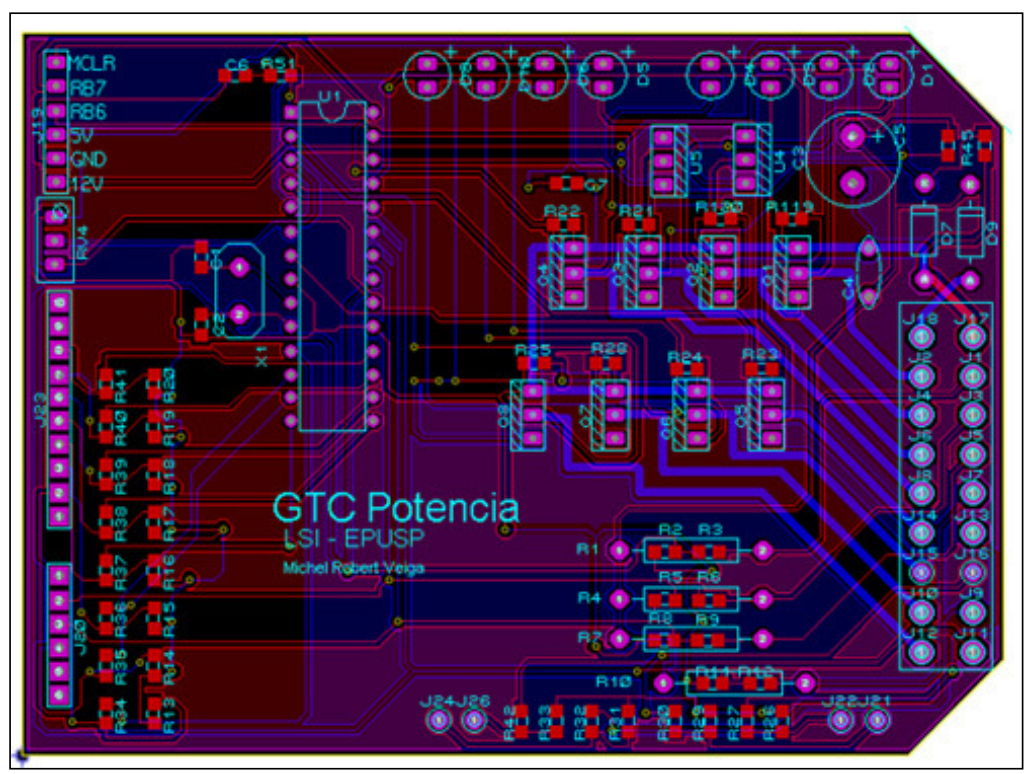

Figura 42 - Leiaute do Circuito da unidade de potência[43].

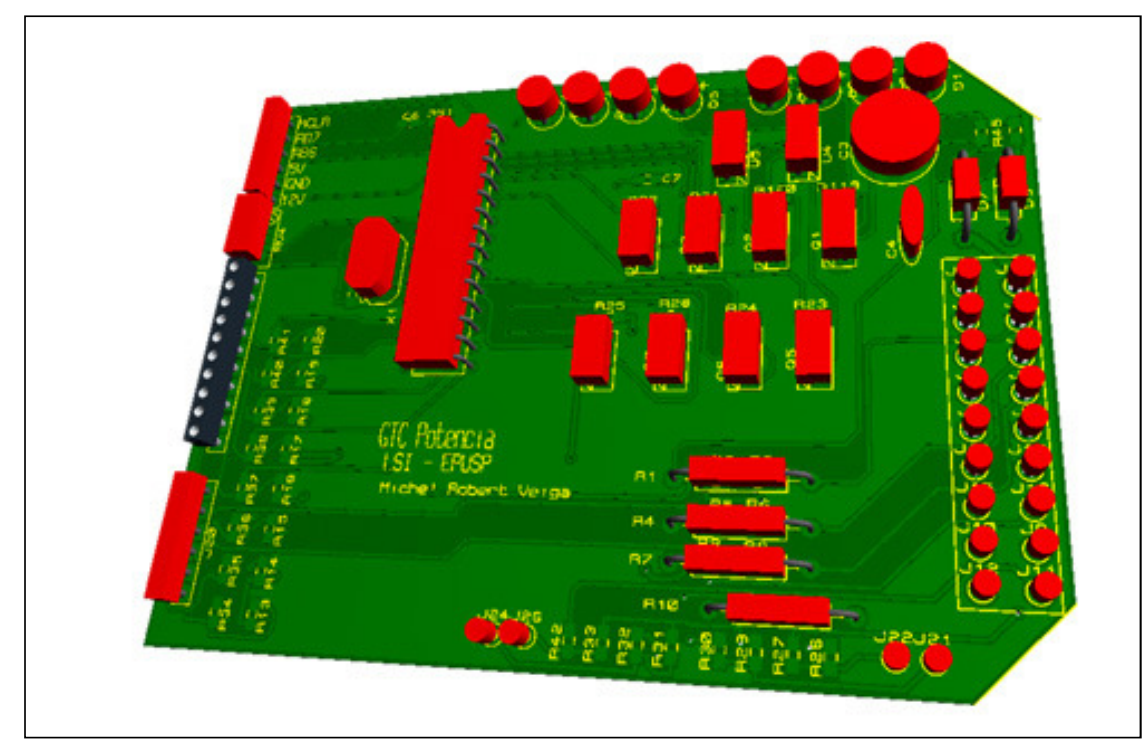

Figura 43 - Simulação em 3D do circuito impresso da unidade de potência [43]. 
A placa possui saída para acionamento de 9 atuadores, sendo 4 válvulas injetoras de combustível líquido , 4 válvulas injetoras de GNV, e uma válvula solenoide do GNV.

\subsubsection{Comunicação serial e LCD}

Para visualizar o valor de alguns dados importantes para calibração e desenvolvimento do protótipo, foi introduzido um display de LCD de 16 colunas e 4 linhas, e um módulo de comunicação serial. A comunicação serial unidirecional foi selecionada, pois utiliza apenas um pino do microcontrolador para recepção do sinal a ser enviado ao LCD. Na Figura 44 é apresentado o circuito eletrônico. Na Figura 45, a foto do painel com display de LCD instalado dentro do veículo utilizado para calibração e na Figura 46, a imagem em 3D da placa de circuito impresso.

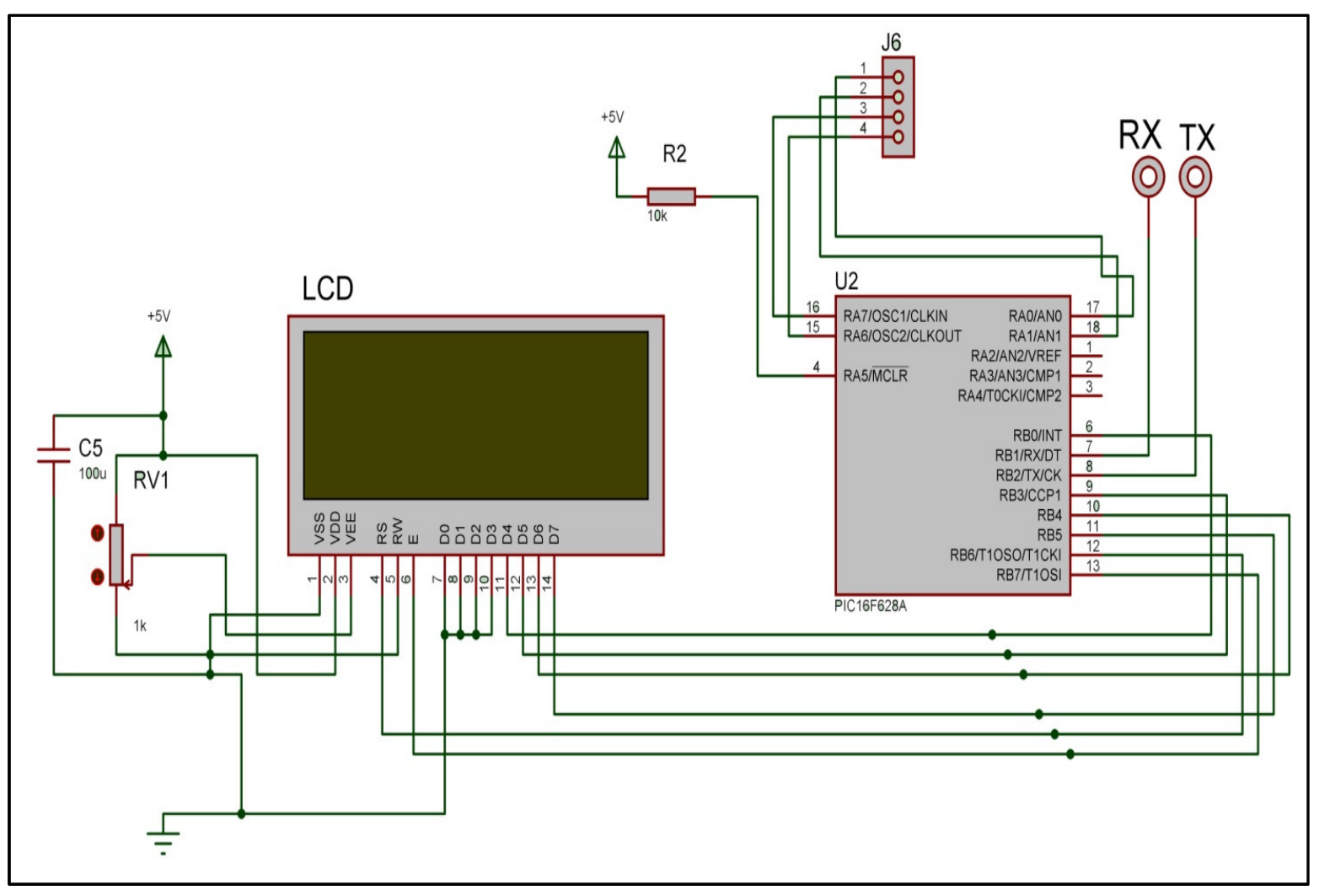

Figura 44 - Circuito eletrônico do display de LCD com comunicação serial[43]. 


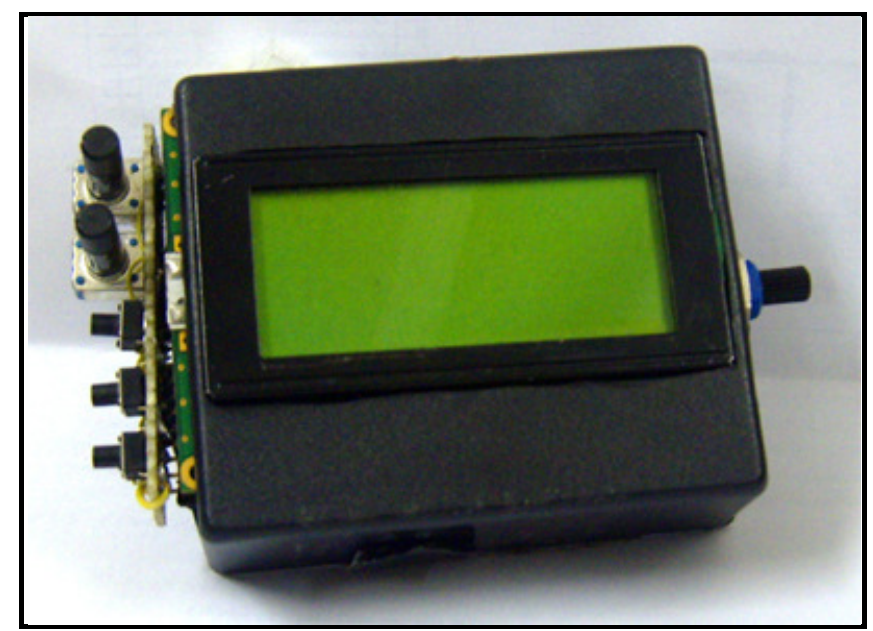

Figura 45- Display Interno [43].

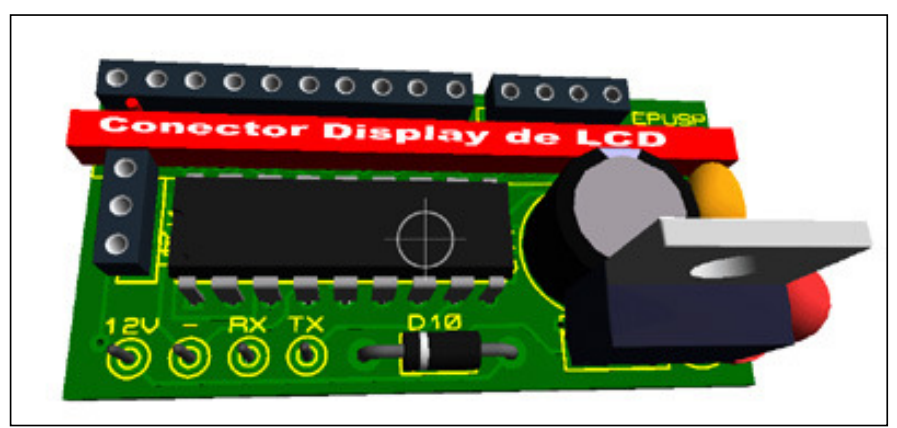

Figura 46 - Imagem em 3D da Placa de Circuito impresso [43].

\subsubsection{Comunicação paralela}

O controlador principal é responsável pela determinação do tempo de injeção que é enviado ao módulo de potência, através de uma comunicação paralela assíncrona. Essa comunicação tornou-se viável, pois foi necessária apenas a transmissão da variável correspondente ao tempo de injeção, sendo possível uma transmissão contínua de uma variável de 8 bits. $\mathrm{O}$ valor é enviado pelos 8 pinos do Port B do PIC16F877 ao Port C do Pic16F870 conforme Figura 47. 


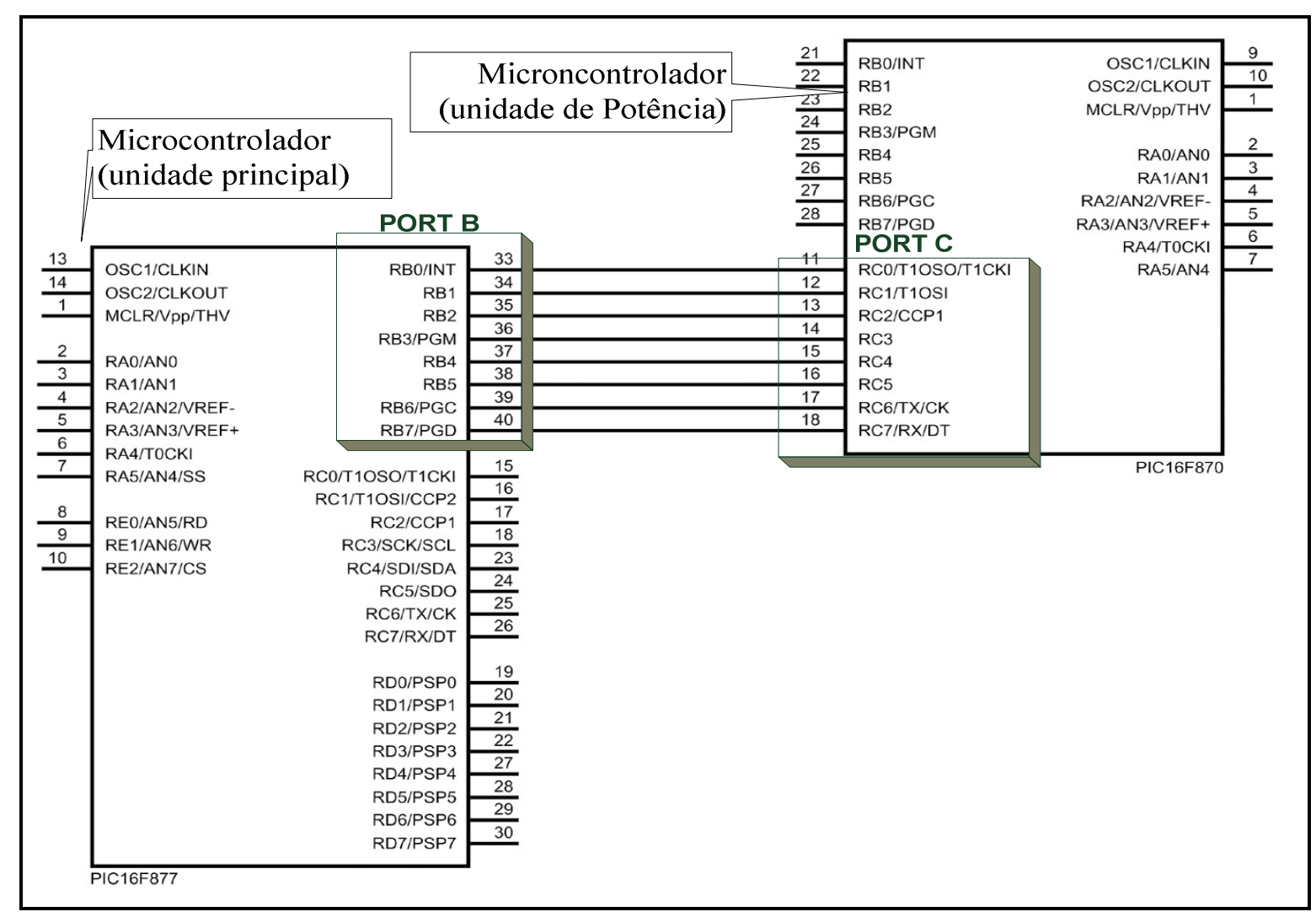

Figura 47 - Comunicação paralela[43].

\subsection{LÓGICA DE CONTROLE.}

Nesse capítulo, são apresentadas as equações utilizadas no sofware do protótipo.

\subsubsection{Equações para uso de etanol e/ou gasolina}

Em um veículo original a gasolina, a UCE calcula o tempo de injeção através dos dados dos sensores. Eesses dados são submetidos a tabelas, ou mapas de injeção, para que se conheça o tempo de injeção.

Em uma conversão de um veículo original a gasolina para bicombustível, é preciso recalcular o tempo de injeção em relação à quantidade de etanol adicionado à gasolina, uma vez que o etanol tem poder energético $30 \%$ menor. A variação desse tempo em relação aos dois 
combustíveis é linear e pode ser feita em porcentagem, sendo proporcional à quantidade de etanol na gasolina, onde $30 \%$ é o maior valor para o uso somente de etanol. Esse valor pode variar de acordo com o veículo, porém é utilizado na maioria dos conversores bicombustível comerciais.

Para calcular a quantidade de etanol na gasolina, é feita uma estimativa através dos dados obtidos pelo sensor de oxigênio. Com esse dado, é feita uma multiplicação para adicionar o tempo de injeção proporcional ao tempo de injeção original para gasolina.

Para a conversão do Daewoo Lanos de gasolina para bicombustível, foi utilizada a eq.(13)

$T i_{\text {original }}=$ tempo de injeção original do veículo

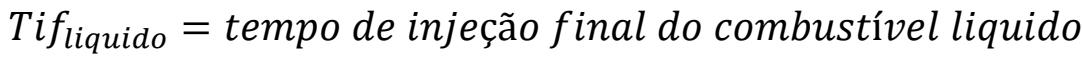

Fce = fator de correção do etanol

$$
\text { Tif }_{\text {líquido }}=\text { Ti }_{\text {original }} \text { Fce }
$$

Uso somente de gasolina: $\mathrm{Fce}=1$

Uso de gasolina e etanol: $0<$ Fce $<1,3$

Uso somente de etanol: Fce $=1,3$

O valor máximo para o fator de correção é de 1,3, pois é suficiente para compensar a diferença de poder energético do etanol em relação à gasolina, que é de $30 \%$. Valores superiores só serão utilizados em casos onde há alterações mecânicas no sistema de admissão que proporcione aumento na massa de ar admitida.

Em adaptações de conversão, pode se obter o fator de correção de forma empírica para um ajuste manual do Fce, ou de forma automática através do sinal do sensor de oxigênio.

Essa técnica de conversão de gasolina para bicombustível só funciona porque a curva de injeção para os dois combustíveis são parecidas e funcionais apenas com um incremento. Porém, isso não ocorre com a injeção de GNV. 


\subsubsection{Equações para o uso exclusivo de GNV}

Através de alguns ensaios, foram feitas tentativas de se estabelecer um fator de correção para o GNV, com base no tempo de injeção original do veículo. O funcionamento só foi satisfatório em uma faixa estreita de rotação, ou seja, se o ajuste for feito para rotação entre 2500 a $3000 \mathrm{rpm}$, o funcionamento fica prejudicado para rotações fora dessa faixa. Para solucionar esse problema, foi necessário estabelecer um fator de correção em função da rotação do motor, de acordo com a eq.(14).

$$
T i g_{g n v}=T i_{\text {original }} \cdot F C_{g n v}
$$

$T i g_{g n v}$ é o tempo de injeção final do GNV

Ti $i_{\text {original }}$ é o tempo de injeção original do veículo enviado pela ECU

$F c_{g n v}$ é fator de correção do GNV

O fator de correção do GNV foi estabelecido através da soma de dois fatores de correção, utilizando a rotação do motor e uma constante do veículo.

À medida que a rotação aumenta, a proporção do tempo de injeção em relação ao tempo de injeção inicial deve sofrer uma redução, muito provavelmente devido ao fato de que o GNV ocupa o espaço do cilindro que seria ocupado pelo ar. Essa afirmação se baseia na leitura da sonda lambda, que mostra um enriquecimento da mistura superior ao comparado quando utilizando somente etanol.

O fator de correção do GNV em função da rotação foi estabelecido conforme relação da eq.(15).

$$
F C_{r p m}=\frac{R M P}{70000}
$$

Para rotação de 0 a $7000 \mathrm{rpm}$, o fator de correção varia de 0 a 0,1 , proporcionando um decremento de $10 \%$ no tempo de injeção final. 
Para o ajuste correto do tempo de injeção do GNV, é necessário mais um fator de correção constante. Esse valor pode ser diferente em cada veículo e deve ser estabelecido alterando esse valor até se obter uma mistura estequiométrica, através da leitura da sonda lambda.

FCi = Fator de correção da injeção de GNV.

A equação final para o Fator de correção do GNV dada na eq.(16).

$$
F C_{g n v}=F C i+F C_{r p m}
$$

\subsubsection{Equações para o uso simultâneo de GNV e etanol e/ou gasolina}

Para adicionar a função de mistura do combustível líquido e GNV, foi criada uma variável para definir a proporção dessa mistura de acordo com a eq.(17).

$$
M G_{g n v}+M l_{\text {líqudio }}=1
$$

$M G_{\text {gnv }}>0,2 M l_{\text {liquido }}>0,2$

$\mathrm{MG}_{\mathrm{gnv}}$ - Mistura de GNV (defini a porcentagem de GNV na mistura)

$\mathrm{Ml}$ - Mistura do combustível líquido (defini a porcentagem do combustível líquido na mistura)

O limite mínimo para as variáveis MG e Ml são para evitar os efeitos de histerese que ocorrem devido à inércia no tempo de abertura da válvula, sem que ocorra a passagem do combustível. Através de ensaios realizados, observa-se o funcionamento irregular do motor para valores de $\mathrm{Mg}$ e $\mathrm{Ml}$ menores que 0,2, apresentando, marcha lenta irregular e mistura pobre.

Adicionando o fator referente à proporção dos combustíveis na eq.(13) e eq.(14), obtêm-se as eq.(18) e eq.(19), com o tempo de injeção final do combustível líquido e do GNV.

$$
\text { Tif }=T i_{\text {original }} . F c e . M l_{\text {líqudio }}
$$




$$
T i_{g n v}=T i_{\text {original }} \cdot F C_{g n v} \cdot M G_{g n v}
$$

Através das equações acima, é obtido um sistema em malha aberta. Entretanto, a variável referente ao tempo de injeção original do veículo (Ti original) é calculada na ECU original do veículo, que possui malha fechada. Com essa realimentação, observam-se momentos de descontrole da estequiometria, deixando a mistura rica ou pobre, tornando necessária a inclusão de mais uma variável de realimentação do sistema utilizando o fator lambda, como é mostrado nas equações eq.(20) e eq.(21).

$$
\text { Tif }=\text { Ti }_{\text {original }} . \text { Fce. } M l_{\text {líqudio }} \cdot \text { Fat }_{\text {lambda }}
$$

$$
T i_{\text {gnv }}=T i_{\text {original }} \cdot F C_{g n v} \cdot M G_{g n v} \cdot F a t_{\text {lambda }}
$$

Substituindo $F C_{g n v}$ da eq.(16) na eq.(21) obtêm-se a eq.(22).

$$
T i_{\text {gnv }}=T i_{\text {original }} \cdot\left(F C i+\frac{R P M}{70000}\right) \cdot M G_{g n v} \cdot F a t_{\text {lambda }}
$$

O Fator de correão do GNV é determinado através de testes de potência apresentados no Gráfico 6 na pagina 103.

\subsection{INSTALAÇÃO DO SISTEMA DE GNV CONVENCIONAL POR ASPIRAÇÃO.}

Foi instalado no veículo de teste o sistema convencional de conversão por aspiração. A instalação do sistema convencional foi necessária para mensurar as melhorias proporcionadas pelo protótipo desenvolvido.

A primeira parte da instalação consiste na fixação do suporte de cilindro e o cilindro de GNV no porta malas, conforme apresentados nas Figuras 43 e 44, e a instalação da tubulação até a 
parte dianteira do veículo ligada a válvula de abastecimento, vista na Figura 50.

Existe no mercado cilindros de diversas dimensões. A Cilbras possui a linha chamada de light, cujo menor cilindro tem as seguintes características: pressão de serviço, 200bar, pressão de ruptura acima de 500bar, capacidade hidráulica de 30L, diâmetro externo de 230mm, comprimento total de $860 \mathrm{~mm}$, peso $32 \mathrm{Kg}[46]$.

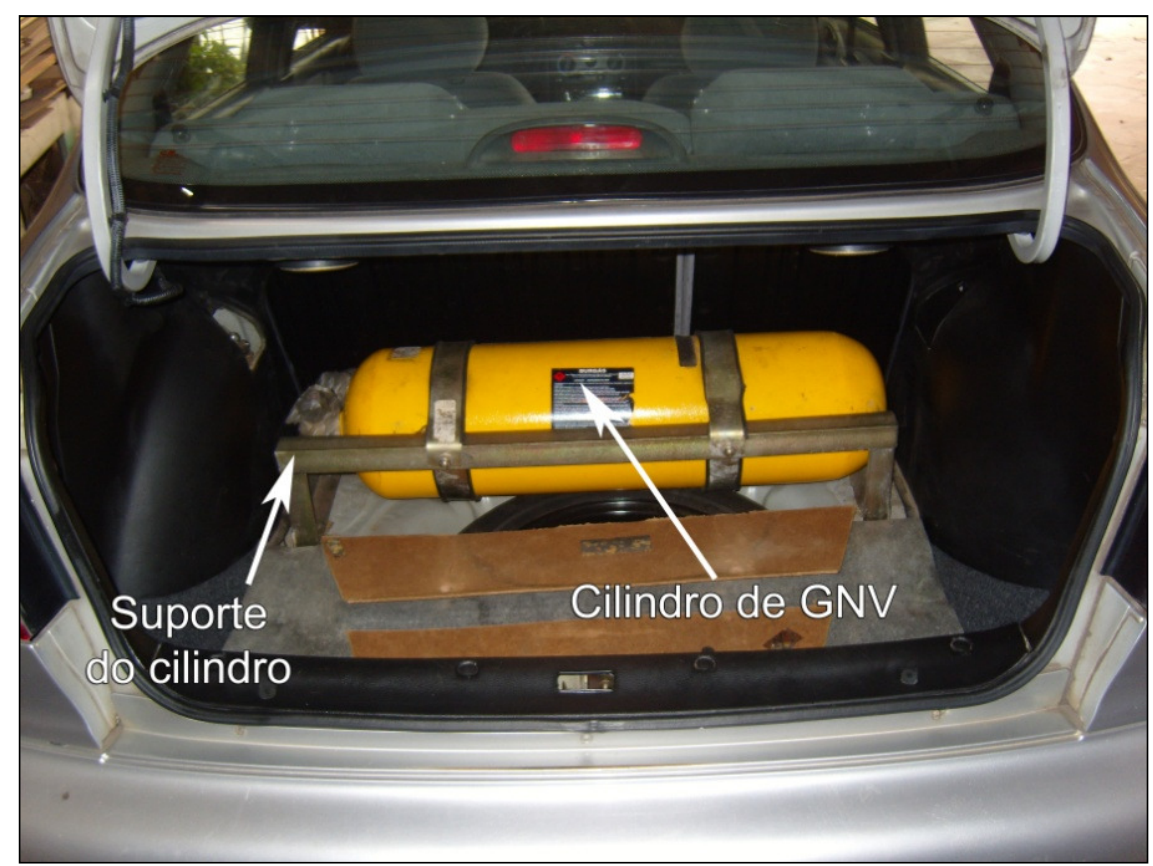

Figura 48 - Cilindro de 7,5m³ , instalado no porta malas do Daewoo Lanos[33].

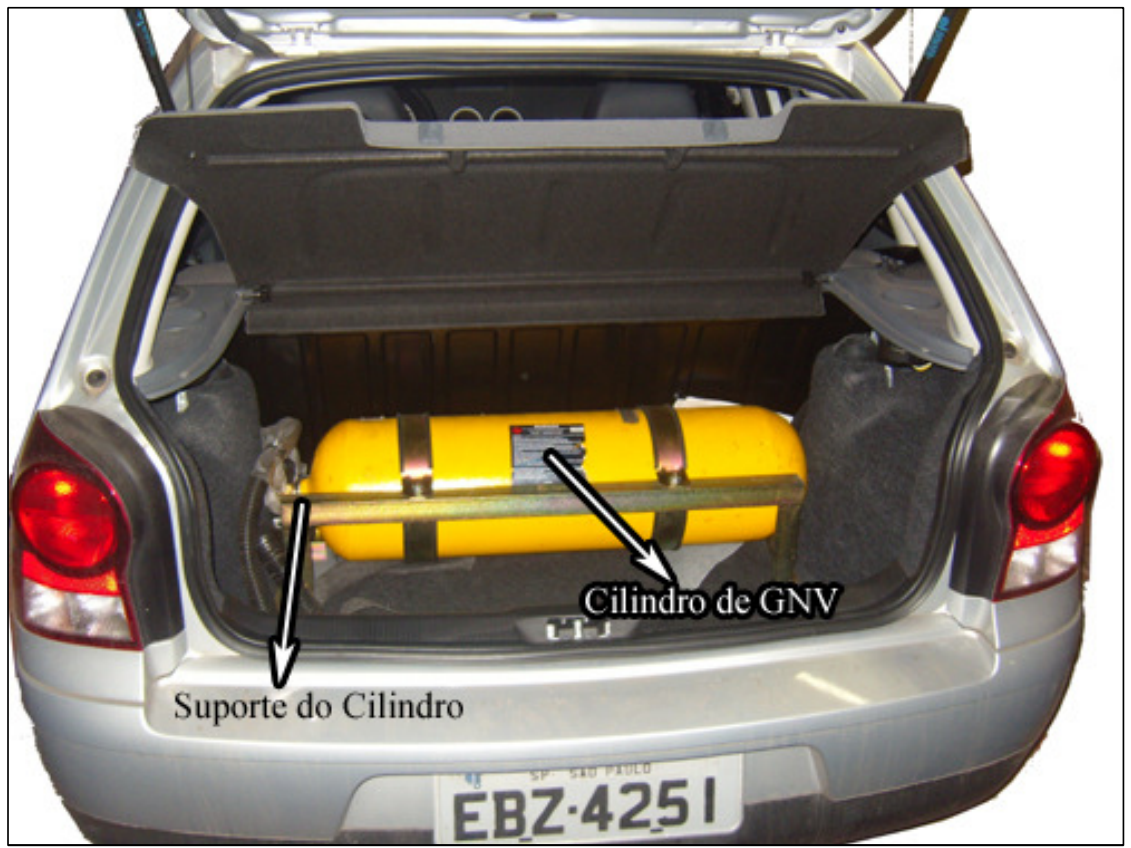

Figura 49 - Cilindro de 7,5 $\mathrm{m}^{3}$, instalado no porta malas VW Gol[33]. 


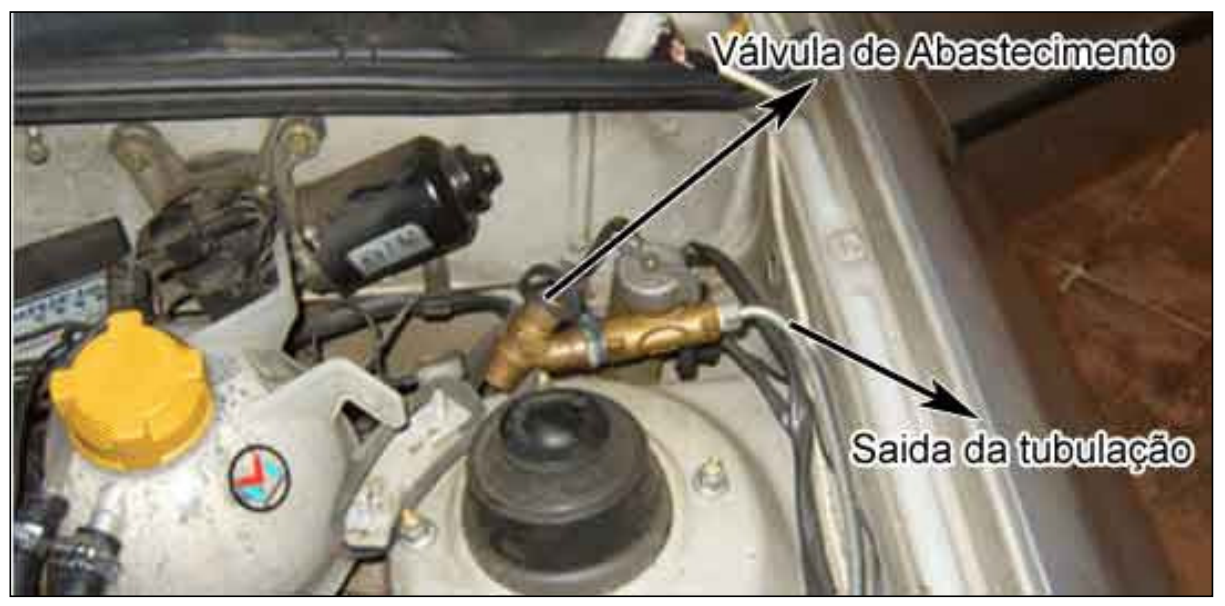

Figura 50 - Instalação da válvula de abastecimento instalada no Daewoo Lanos[33].

Após a válvula de abastecimento, uma pequena tubulação é ligada ao o redutor de pressão, como é mostrado na Figura 51. O redutor de pressão reduz a pressão máxima de abastecimento de 215,7bar até a pressão atmosférica. O manômetro tem a função de informar a quantidade de combustível, e a válvula solenoide libera ou impede a passagem do gás.

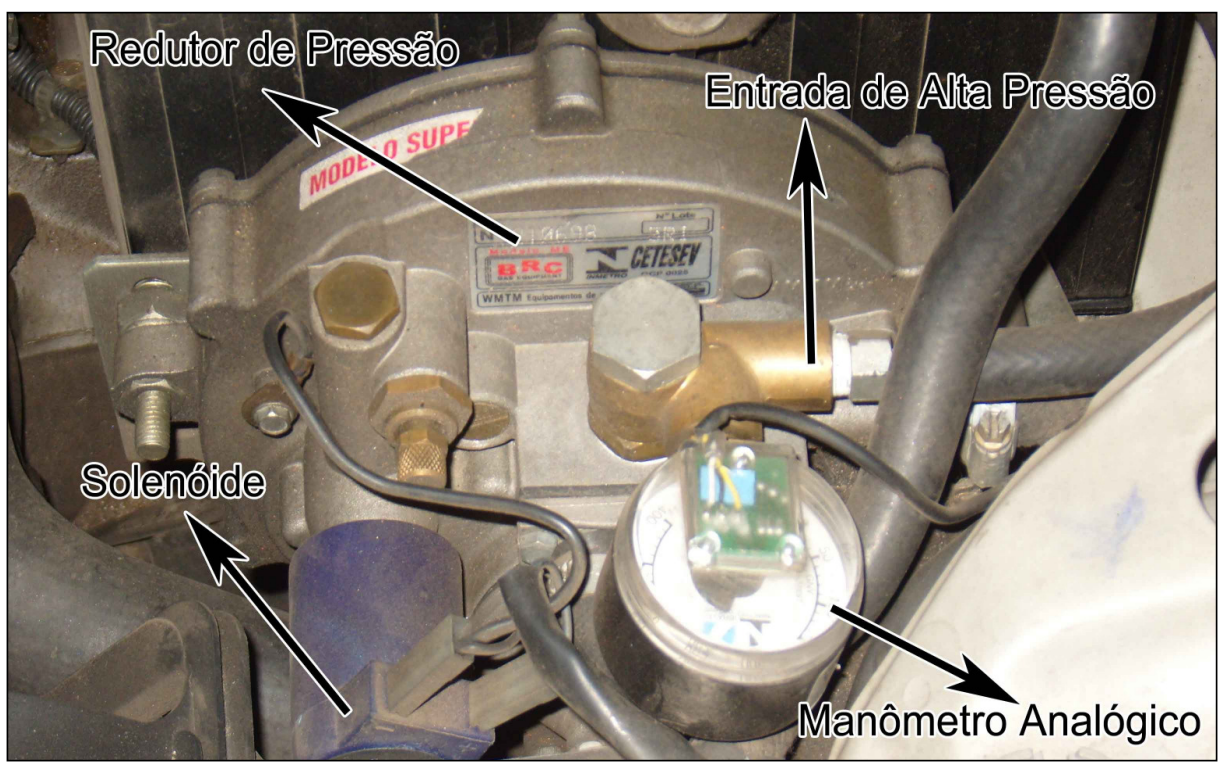

Figura 51 - Redutor de Pressão instalado no Daewoo Lanos[33].

A saída do redutor de pressão é ligada por uma mangueira de baixa pressão até a válvula de controle de fluxo, conhecida como dosador. 


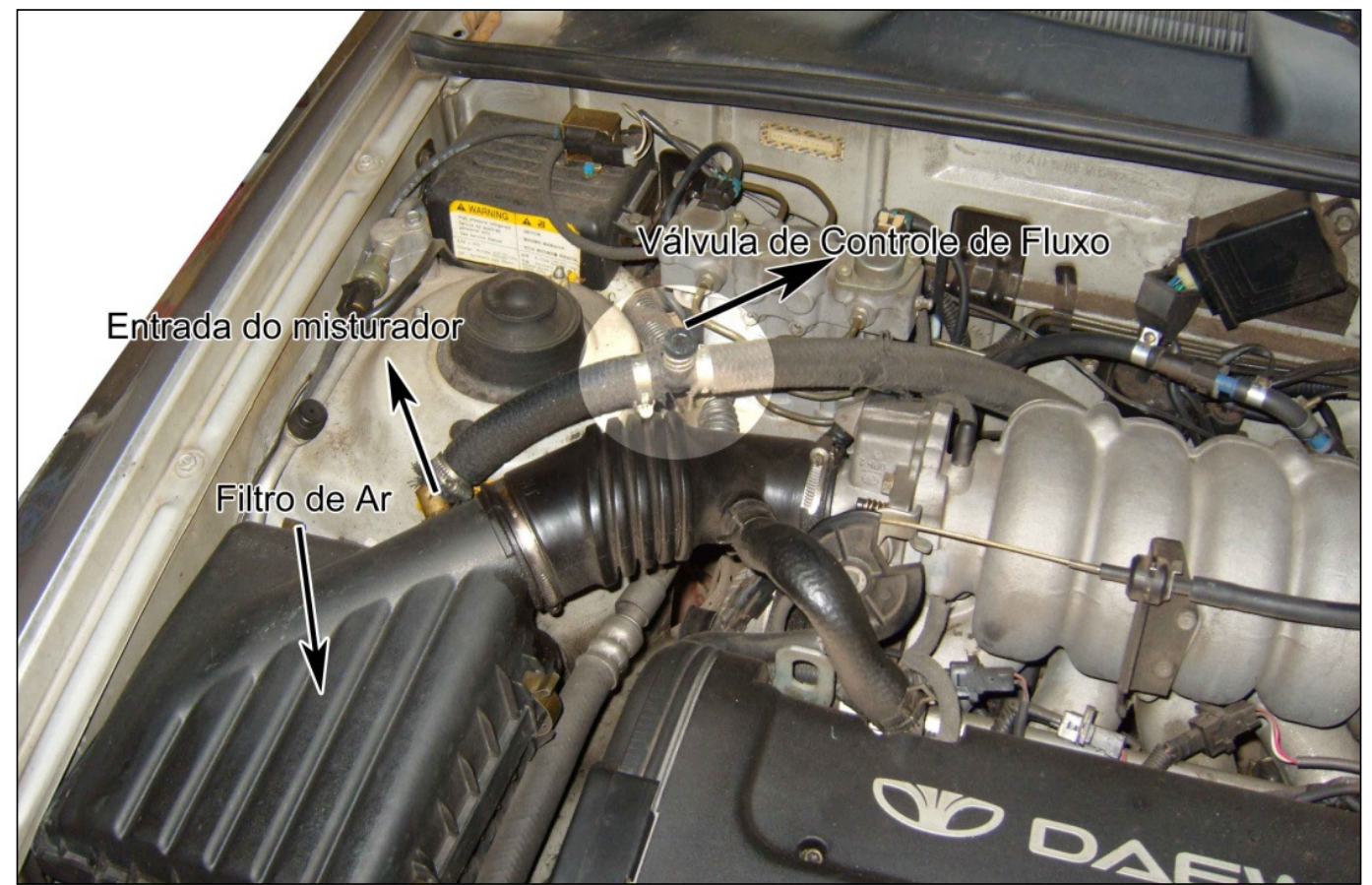

Figura 52 - Instalação da válvula de fluxo para alta rotação no Daewoo Lanos[33].

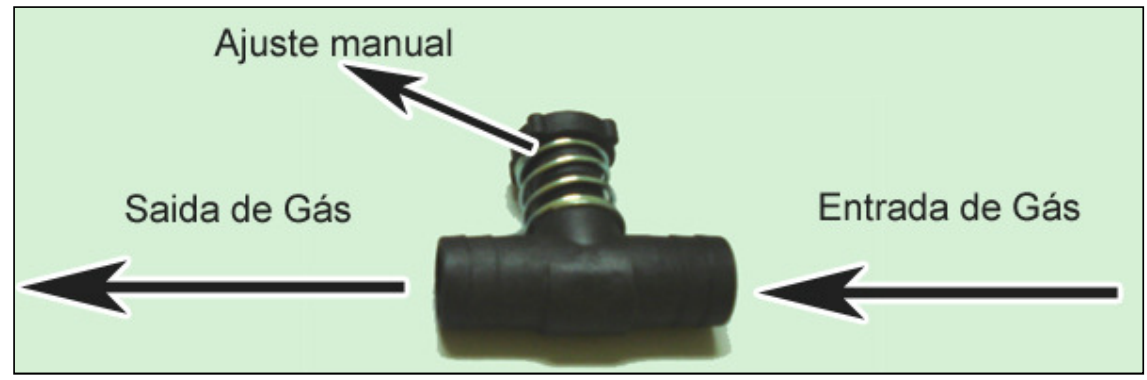

Figura 53 - Válvula de Controle de Fluxo (dosador)[33].

Na Figura 53, pode-se observar a válvula de controle de fluxo para alta rotação com seu ajuste manual.

Após a válvula, uma mangueira leva o gás até o misturador (Figura 54), instalado na tubulação de entrada de ar, entre o filtro de ar e o corpo de borboleta, provocando uma restrição na entrada de ar, gerando depressão suficiente para aspirar o gás para o coletor de admissão. Essa restrição é necessária para que a aspiração e homogeneização do gás sejam feitas corretamente. Contudo, esta restrição causa desvantagens, pois dificulta a entrada do ar, podendo reduzir o rendimento e a potência, mesmo quando utilizado somente o combustível líquido. 


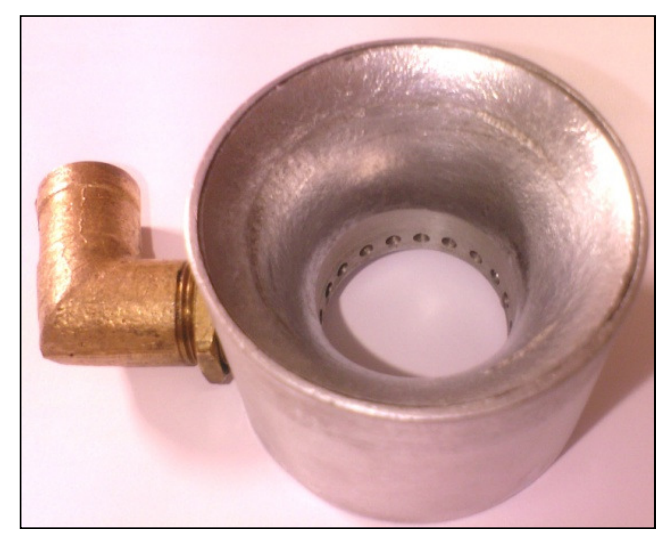

Figura 54 - Misturador de GNV utilizado no Daewoo Lanos[33].

Nos sistema que utilizam o misturador, ao desligar o GNV, o misturador continua provocando restrição na entrada de ar, podendo alterar o funcionamento do veículo, mesmo quando o GNV não for utilizado.

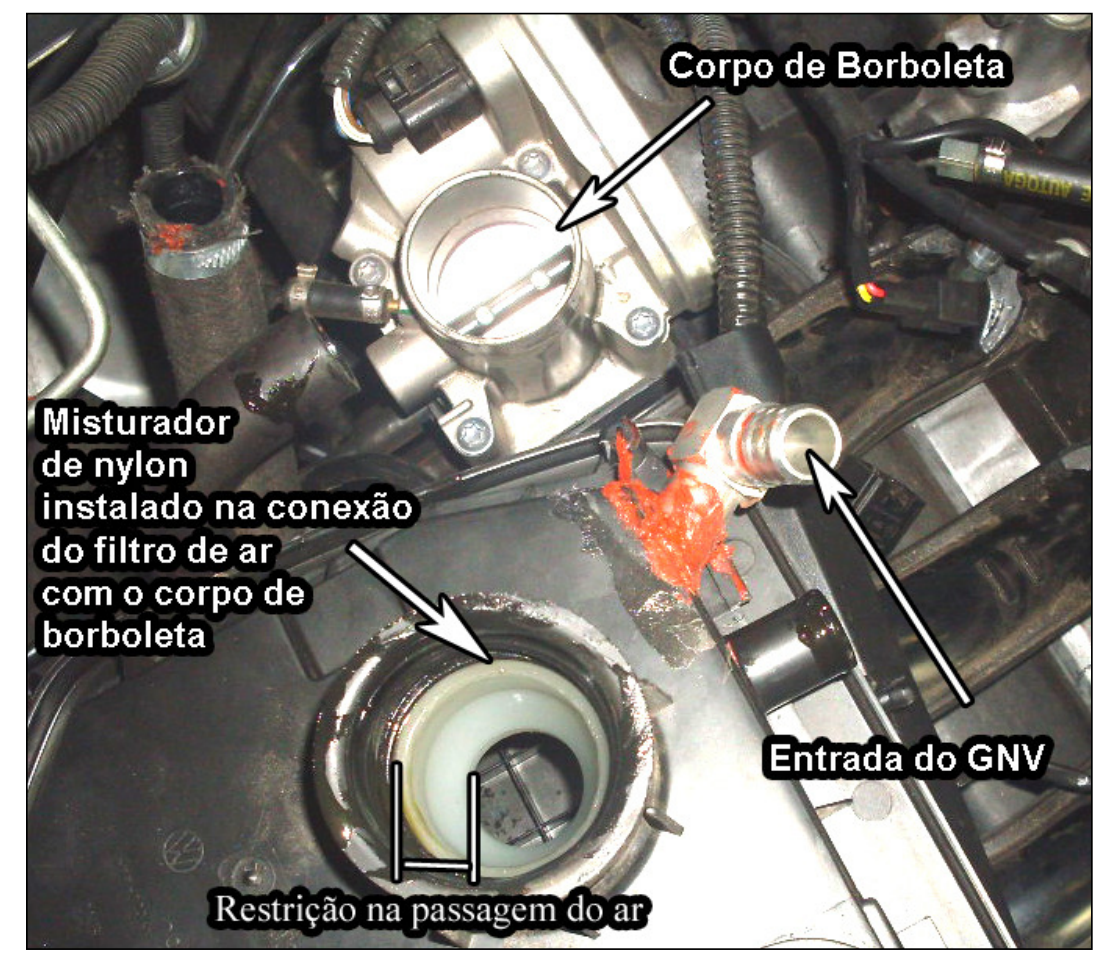

Figura 55 - Instalação do Misturador no VW Gol[33].

Na Figura 55, é apresentada a instação do misturador no VW Gol, onde se observa a restrição provocada na passagem de ar.

No sistema de primeira geração, os dispositivos eletrônicos utilizados são responsáveis por permitir a seleção do combustível por parte do motorista, onde tem-se a chave comutadora, e 
o emulador de bicos como itens principais. O variador de avanço e emulador de sonda lambda são itens opcionais, pois dependem da tecnologia original do veículo.

A chave comutadora utilizada possui um botão com 3 opções. Com a posição para direita, o veículo funciona somente com o combustível líquido. Com a chave na posição central, o funcionamento ocorre apenas com o GNV aspirado, e quando posicionada para esquerda, a partida é feita com o combustível líquido e, ao acelerar e desacelar, a troca para o GNV aspirado é feita automaticamente.

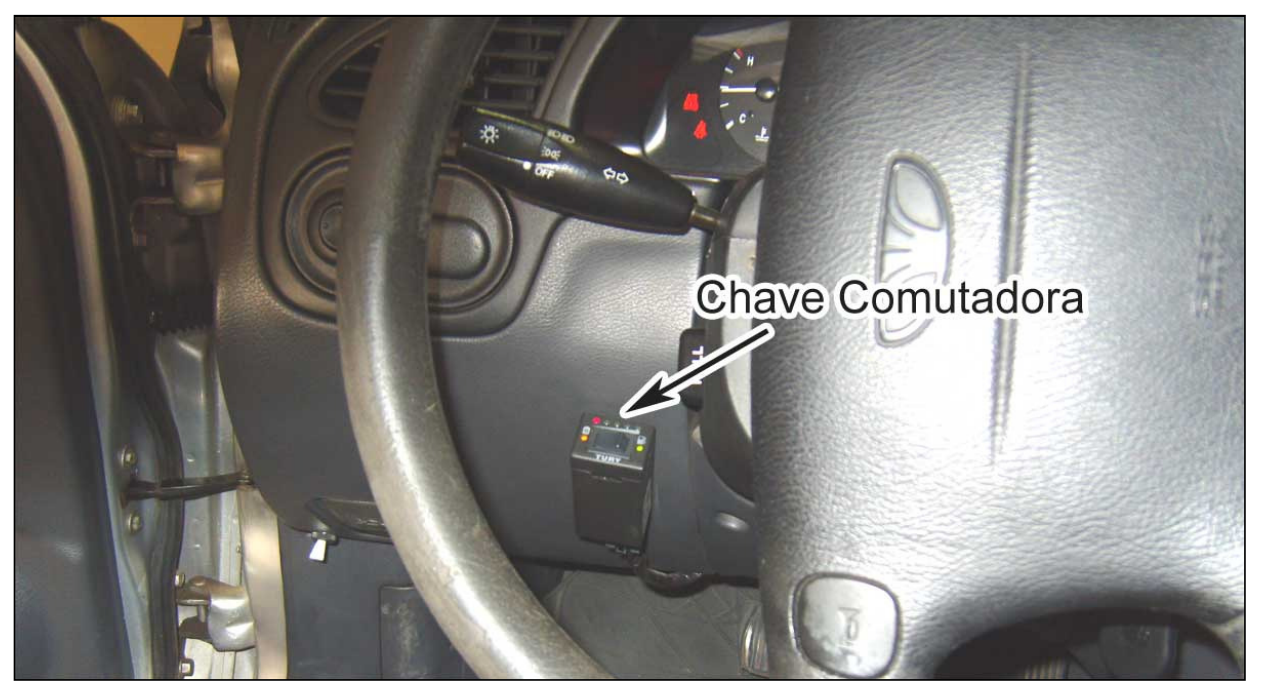

Figura 56 - Instalação da Chave Comutadora no Daewoo Lanos[33].

Outra função da chave é informar a quantidade de GNV no cilindro através da leitura do manômetro instalado no redutor de pressão conforme Figura 57.

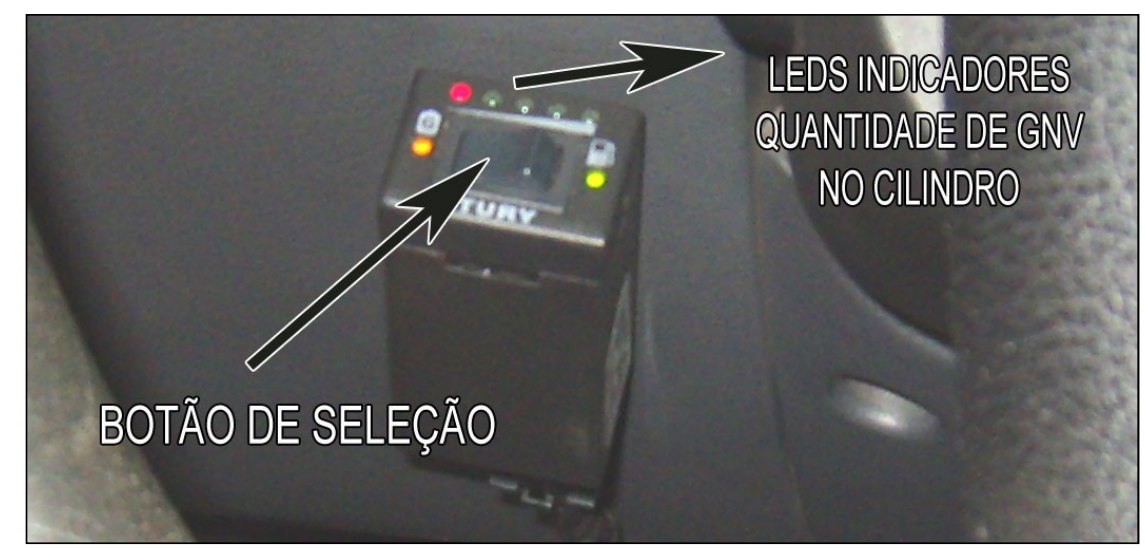

Figura 57 - Chave Comutadora Instalada no Daewoo Lanos[33]. 
A chave comutadora é ligada ao solenoide do redutor de pressão e ao emulador de bico para que, ao selecionar o GNV, o solenoide seja aberto e as válvulas injetoras sejam desligadas. Para que a ECU do veículo não interprete o desligamento das válvulas como falha e adote uma configuração de emergência, a ligação original do bico é desviada através de um relê para um resistor de $120 \Omega$. Eessa forma a ECU não interpreta a falha e não adota nenhuma estratégia de emergência. Mesmo que a resistência do bico injetor seja de aproximadamente $15 \Omega$, o valor adotado de $120 \Omega$ é suficiente para que a ECU não interprete como falha nas válvulas de injeção.

Para o VW Gol, que já possui tecnologia bicombustível original, foi utilizado apenas o emulador de bico, ou válvula. No Daewoo Lanos, foi utilizado um emulador de bicos integrado ao conversor, que gerencia o tempo de injeção para uso de etanol e suas misturas com gasolina quando o combustível líquido é selecionado.

Na Figura 58, é apresentado o esquema de ligação do sistema tricombustível. O sinal das 4 válvulas injetoras enviadas pela ECU do veículo é ligado ao gerenciador tricombustível, que nesse caso tem a função de conversão para bicombustível e emulação de bicos para uso do GNV. A seleção do combustível líquido ou gás é feita através da chave comutadora.

O ajuste de combustível líquido etanol e/ou gasolina é feito através de um botão de ajuste manual. O ajuste manual é feito com o veículo em funcionamento, observando a estequiometria da mistura ar-combustível através da leitura da sonda lambda.

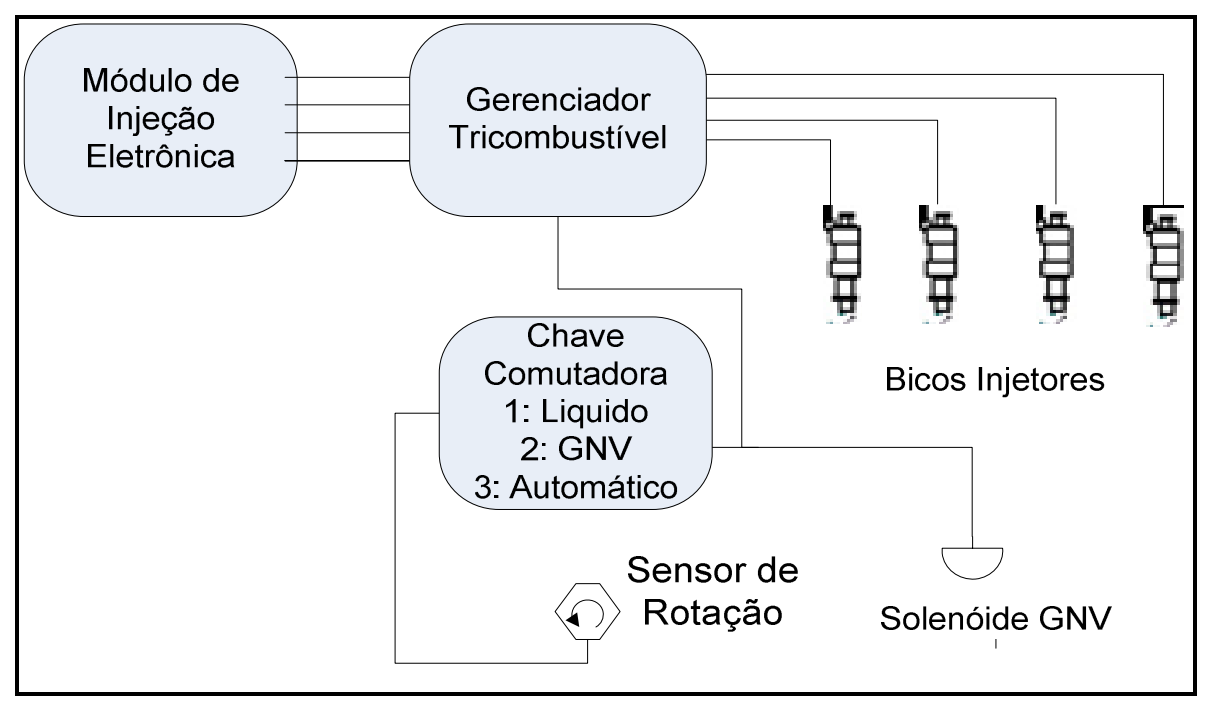

Figura 58 - Esquema de Ligação do sistema de tricombustível[33]. 


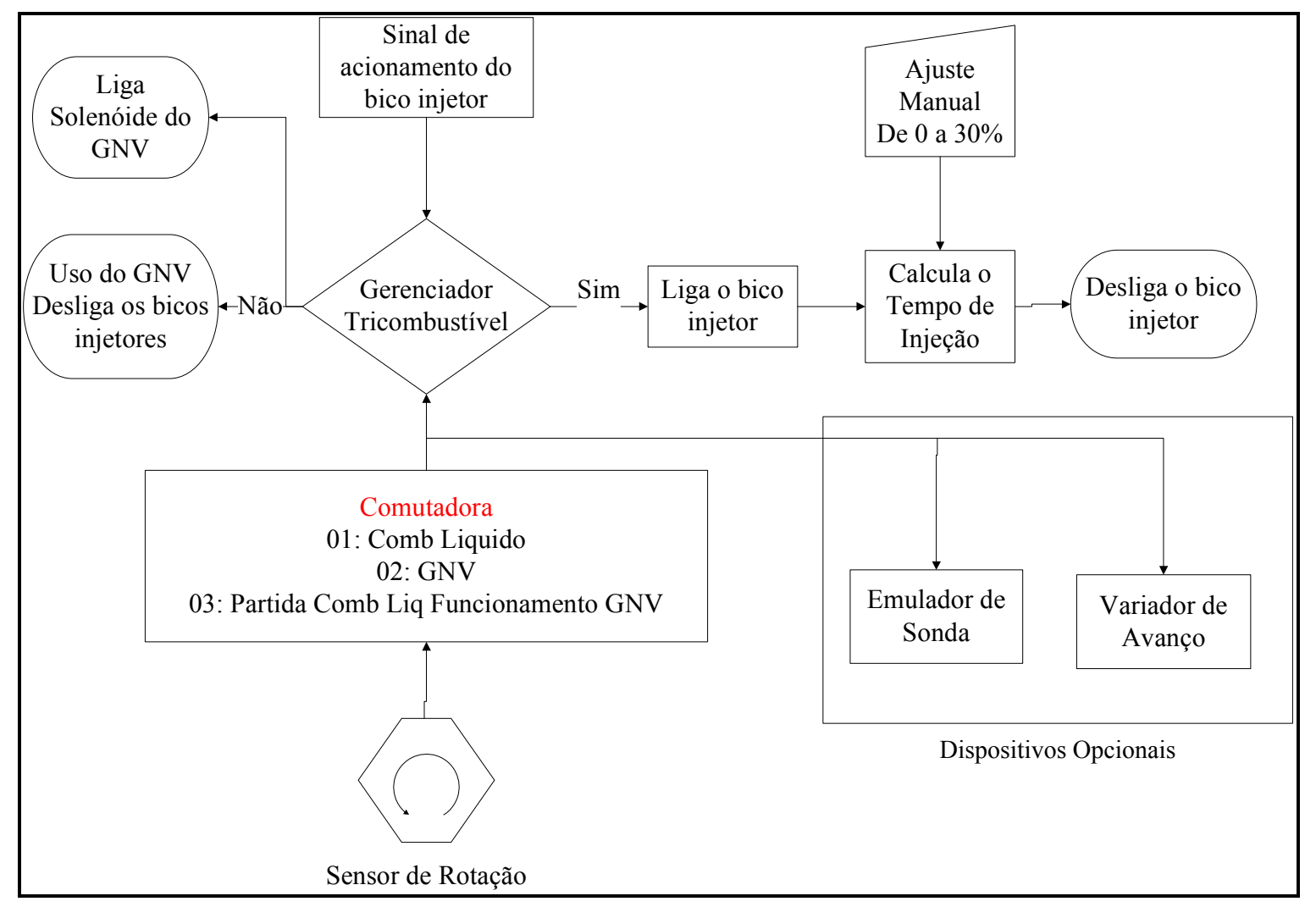

Figura 59 - Esquema simplificado do gerenciador tricombustível[33].

Na Figura 59, é apresentado o esquema simplificado do gerenciador tricombustível. A seleção do combustível é feita através da chave comutadora. Quando selecionada a posição 01, para uso do combustível líquido, um sinal é enviado ao gerenciador, ativando a função de combustível líquido.

Quando a ECU envia o sinal para acionar o bico injetor, esse sinal é lido pelo gerenciador, que aciona a válvula e inicia o cálculo do tempo de injeção original. No instante que a ECU envia o sinal para desligar a válvula, o gerenciador calcula o tempo necessário para conversão e desliga a válvula somente após esse tempo.

Quando acionada a opção 02, o sistema desliga as válvulas injetoras e aciona a válvula solenoide do GNV.

Na posição 03, a chave combina a posição 01 no momento da partida, para facilitar a partida, e troca automaticamente para a posição 02 , quando ocorre uma desaceleração do motor. Isso é feito para que troca de combustível seja feita sem que ocorra falhas provocadas pelo efeito de histerese que ocorre devido ao intervalo de tempo que leva para o GNV chegar ao cilindro após o acionamento da válvula solenoide. 


\subsection{INJEÇÃO MULTIPONTO DE GNV UTILIZANDO AS VÁLVULAS INJETORAS ORIGINAIS DO VEÍCULO}

Este teste tem como objetivo verificar a viabilidade de transformar um sistema de GNV convencional por aspiração em um sistema com injeção positiva, utilizando as válvulas injetoras originais.

\subsubsection{Montagem}

A montagem foi feita desligando o sistema líquido e substituindo pelo sistema de GNV e GLP, seguindo as etapas seguintes:

1 - A bomba de combustível foi desligada e a mangueira de combustível desconectada.

2 - A mangueira que sai do redutor de pressão foi adaptada e conectada à flauta que distribui o combustível às válvulas injetoras.

3 - A flauta possui uma saída ligada a um regulador de pressão e um retorno de combustível, onde este foi obstruído e instalado um manômetro de pressão.

4 - Com pressão de 2,5 bar foram feitas tentativas de colocar o motor de funcionamento variando o tempo de injeção até manter o bico totalmente aberto.

\subsubsection{Funcionamento}

A pressão máxima conseguida foi de 2,5 bar. Entretanto, o redutor utilizado foi projetado para uso com baixa pressão na saída. Ao utilizar a pressão de 2,5 bar, o equipamento apresentou vazamentos.

Com pressão de 2,5 bar, foram feitas tentativas de colocar o motor em funcionamento variando o tempo de injeção até manter a válvula injetora totalmente aberta. Nesse teste, observa-se que, mesmo com a válvula injetora totalmente aberta, a vazão de gás não é 
suficiente para colocar o motor em funcionamento.

Aumentando a pressão para 3,5 bar utilizando um cilindro de GLP doméstico, só foi possível manter a marcha lenta do motor com a válvula constantemente aberta, não sendo possível aumentar a rotação do motor.

Nesse teste, observa-se que não é viável a utilização das válvulas injetoras originais do veículo para injeção de GNV para pressões até 3,5 bar, por não fornecer vazão suficiente para seu funcionamento.

\subsection{INSTALAÇÃO DO SISTEMA DE INJEÇÃO POSITIVA DE GNV}

A instalação do cilindro de gás e a tubulação já haviam sido instaladas no teste anterior, conforme item 3.5. Todos os outros dispositivos instalados para os testes anteriores foram retirados. Uma nova válvula de abastecimento foi instalada, como mostra a Figura 60. Esse dispositivo possui um solenóide para fechar a entrada de gás.

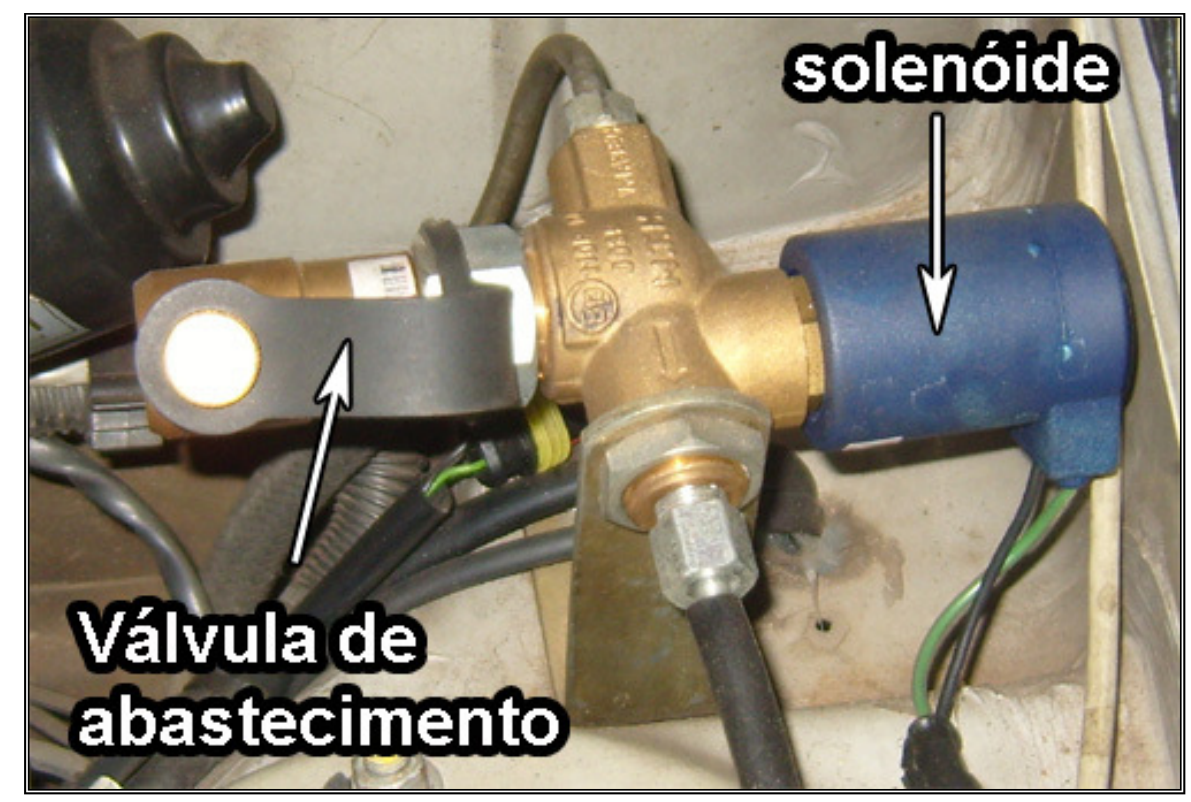

Figura 60 - Válvula de abastecimento[33].

A válvula utilizada no teste anterior não pode ser aproveitada, pois o redutor de pressão não possui válvula solenóide para o corte do gás. Portando, foi necessária a substituição pela válvula de abastecimento, que já possui um solenóide. 
Devido à expansão do gás causar resfriamento, o redutor deve possuir um sistema de aquecimento que evita o congelamento através do líquido de arrefecimento do motor. Integrado ao redutor, tem-se um manômetro de pressão, que tem a função apenas de mostrar a pressão de gás no cilindro para estimar a quantidade. Na Figura 61, são apresentados o redutor de pressão e seus acessórios.

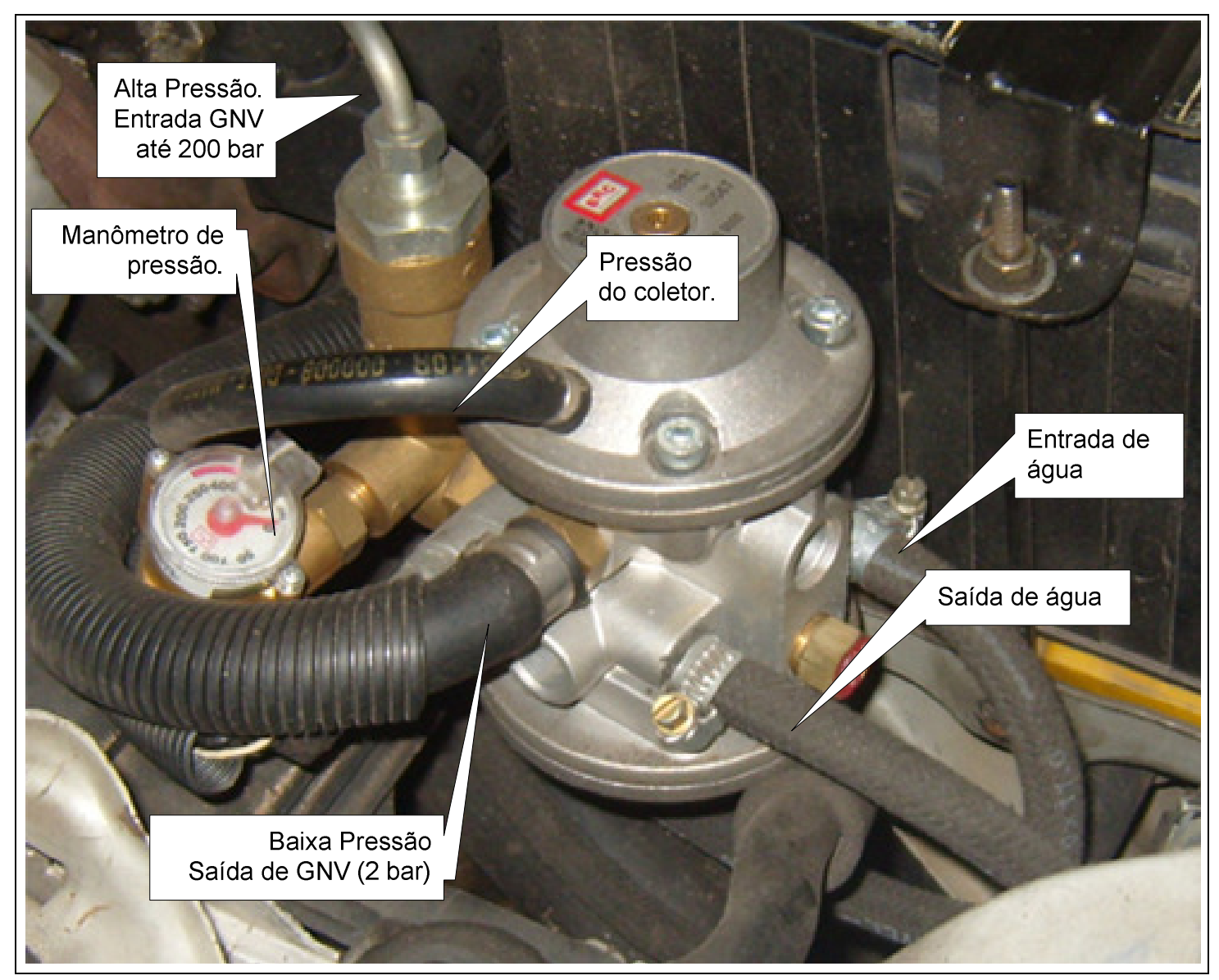

Figura 61 - Redutor de pressão para sistema de pressão positiva[33].

As válvulas injetoras de GNV têm o mesmo princípio de funcionamento das válvula do combustível líquido, controlam o fluxo do combustível através do tempo de injeção. Uma das vantagens em relação ao sistema aspirado é a ausencia do misturador, que provoca restrição na admissão de ar . Para a instalação das válvula injetoras, foram necessários furos no coletor de admissão, como apresentado na Figura 62. 


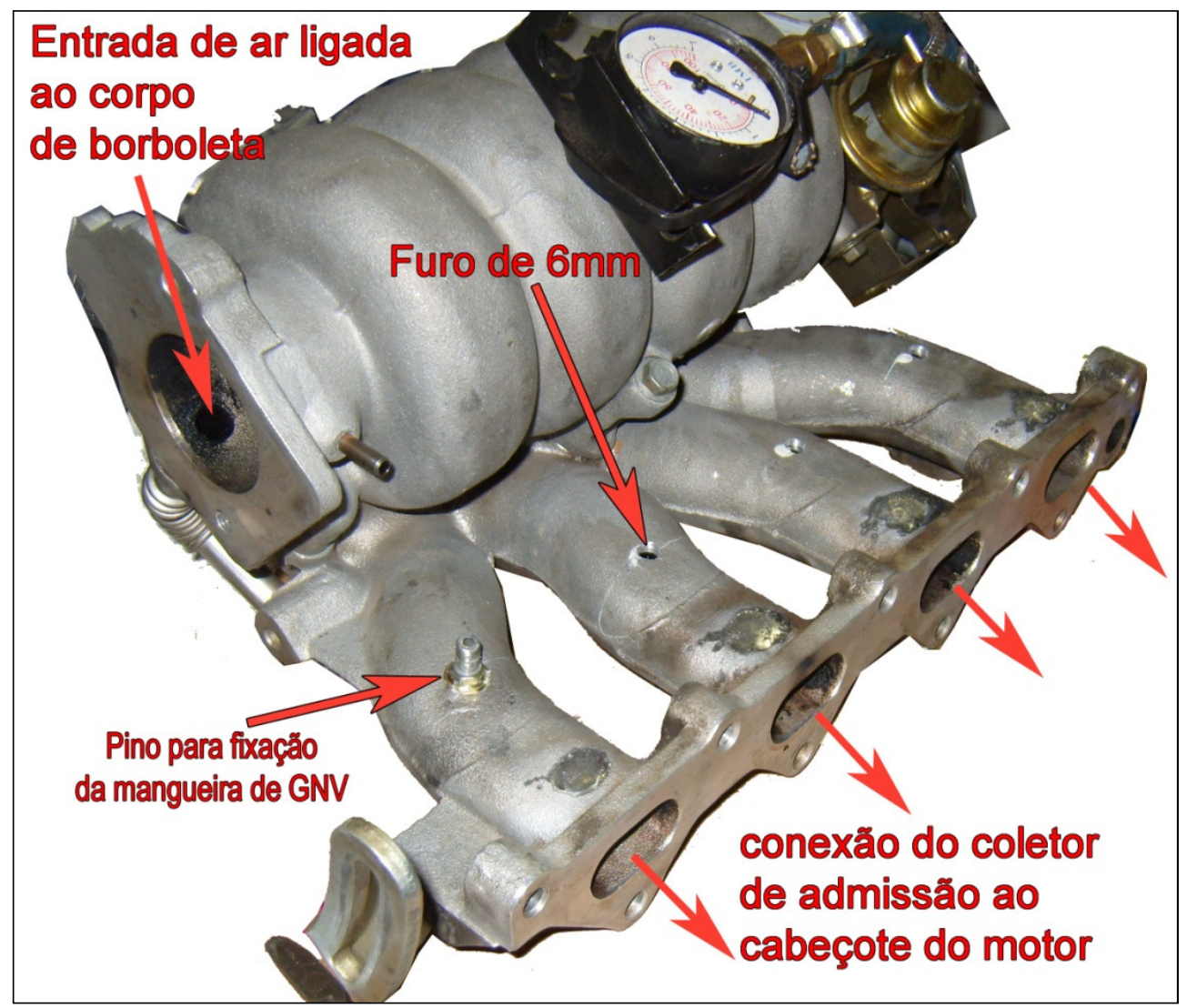

Figura 62 - Furação do coletor do Daewoo Lanos para instalação das válvulas injetoras[33].

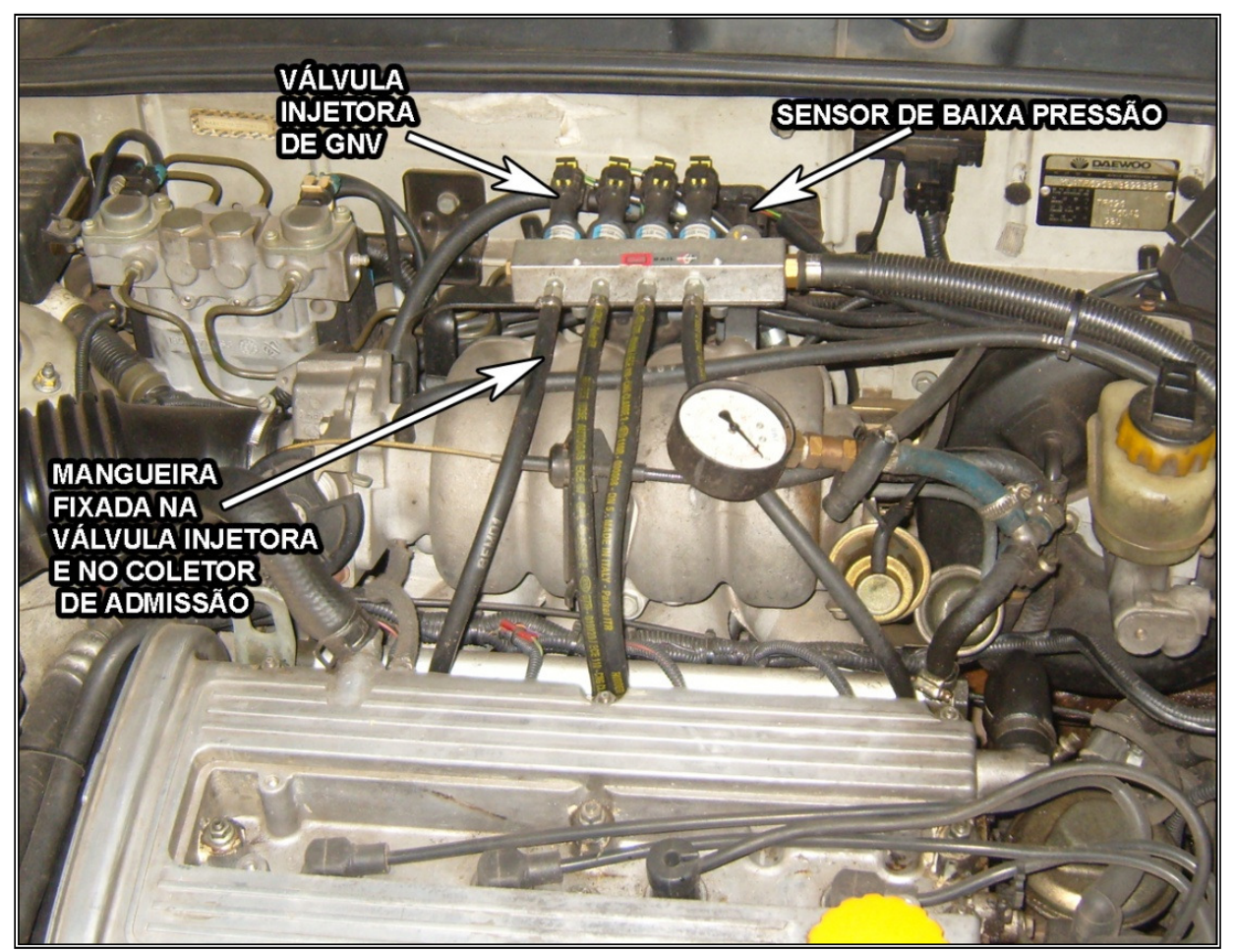

Figura 63 - Válvulas injetoras de GNV instalados no Daewoo Lanos[33]. 
Na Figura 63, são apresentadas as 4 válvulas injetoras já instaladas no Daewoo Lanos, através de mangueiras até o pino de fixação, como mostra a Figura 62.

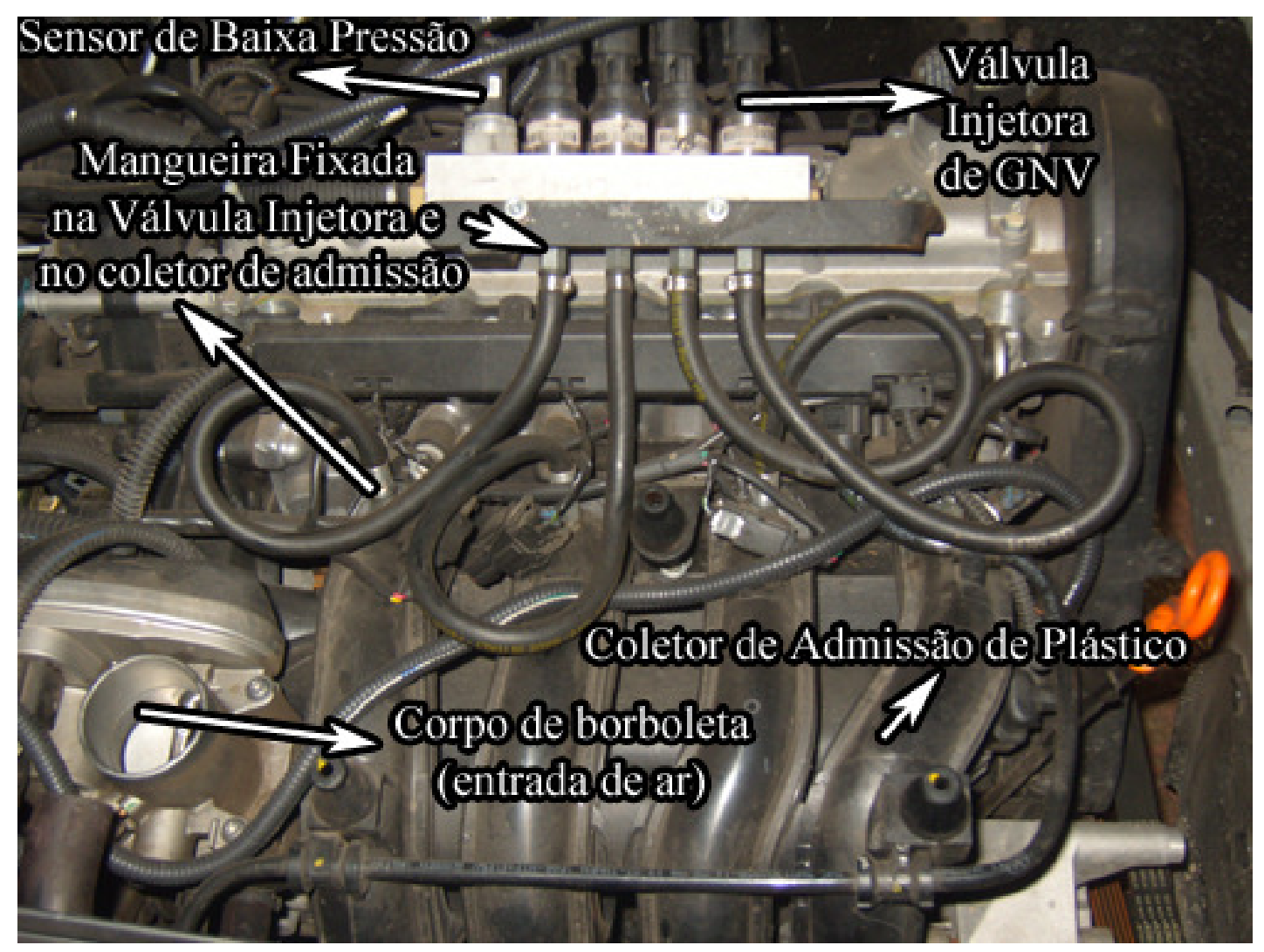

Figura 64 - Instalação do sistema de GNV com pressão positiva no VW Gol[33].

Na Figura 64, tem-se a instalação no VW Gol. A furação feita no coletor de plástico facilita a instalação, quando comparado com o coletor de alumínio do Daewoo Lanos. 


\section{RESULTADOS E DISCUSSÕES}

Nesse capítulo, é apresentada a calibração do dispositivo protótipo, os principais resultados obtidos nos ensaios de consumo, potência e emissão de poluentes, finalizando com uma análise de viabilidade econômica.

\subsection{CALIBRAÇÃO}

Após a instalação do sistema, sendo ele o sistema de primeira geração ou o protótipo desenvolvido, é necessária uma calibração para manter a estequiometria da mistura. Para o sistema aspirado, a calibração é feita através de válvulas manuais. Para o protótipo desenvolvido, é necessária uma calibração inicial para definir as constantes que serão introduzidas no software.

\subsubsection{Calibração para uso do etanol no Daewoo Lanos}

A calibração para uso do Etanol foi feita para o Daewoo Lanos observando a leitura do sensor de oxigênio e ajustando para uma mistura ideal, considerando a variação de tensão de 400 a $600 \mathrm{mV}$ como ideal. Através da equação dada pela eq.(10), ficou estabelecido Fce=1,1. O aumento de $10 \%$ foi suciente para que o sistema de malha fechada original funcionasse perfeitamente com o etanol.

Para calibração do sistema de GNV aspirado, o procedimento é o mesmo para os dois veículos de teste, utilizando a leitura do sinal do sensor de oxigênio para o ajuste de mistura ideal.

O primeiro procedimento é o ajuste de marcha lenta, onde se busca mistura ideal através do ajuste de duas válvulas do redutor de pressão, como apresentado na Figura 65 . 


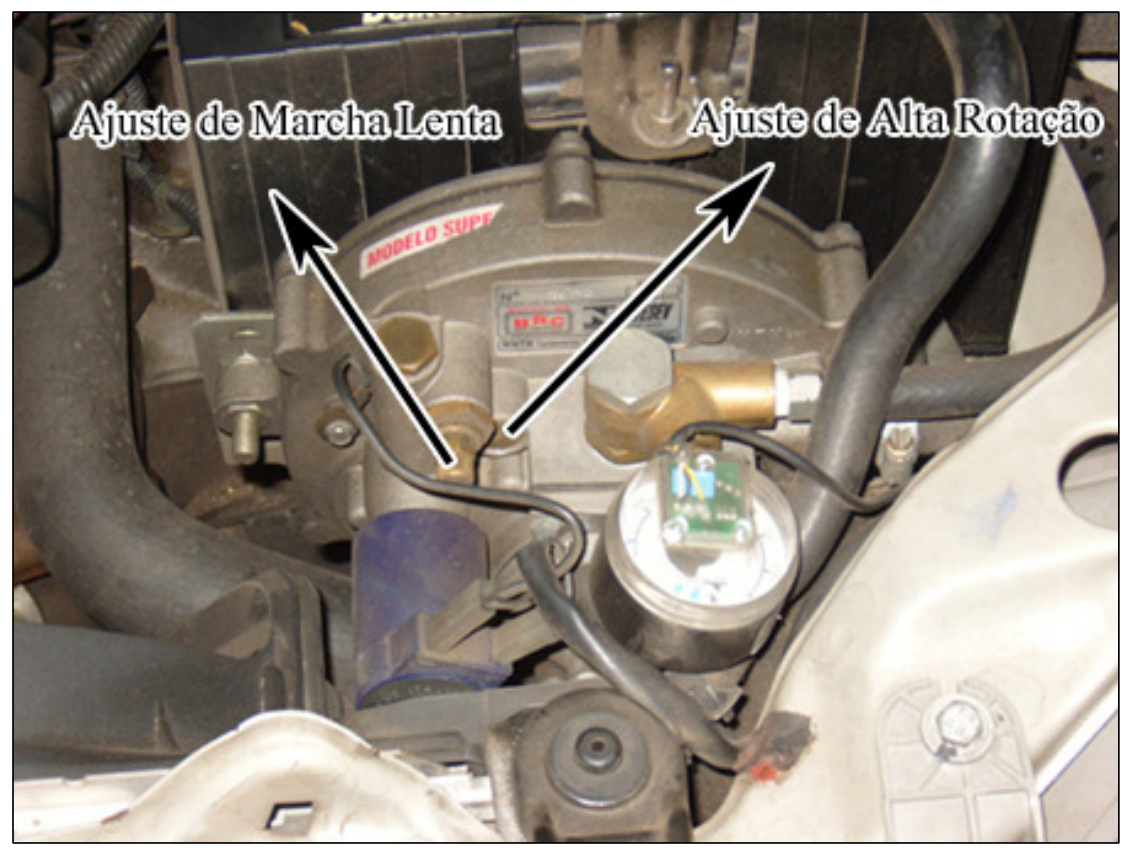

Figura 65 - Redutor de pressão[33].

Após a calibração da marcha lenta, o veículo foi acelerado até a rotação aproximada de 2500 rpm, onde nova calibração é feita utilizando a válvula de controle de fluxo.

\subsubsection{Calibração do Daewoo Lanos para uso do GNV no sistema de injeção positiva}

O objetivo da calibração é definir o valor que representa a constante do veículo para que o tempo final de injeção possa ser calculado segundo eq.(23), para o tempo de injeção do GNV.

$$
T i_{\text {gnv }}=T i_{\text {original }}\left(F C i+\frac{R P M}{70000}\right) \cdot M G_{g n v} \cdot F a t_{\text {lambda }}
$$

$\boldsymbol{T} \boldsymbol{i}_{\text {gnv }}=$ tempo de injeção do gnv

FCi = fator de correção da injeção de gnv

RPM = leitura através do sensor de rotação

$\boldsymbol{M} \boldsymbol{G}_{\boldsymbol{g n v}}=$ mistura de gnv, para uso somente de GNV =1

$\boldsymbol{F a t}_{\text {lambda }}=$ correção através da leitura da sonda lambda (mistura pobre ou rica) 
Para completar a equação, é preciso definir o valor do FCi. Para isso o valor do FCi foi alterado manualmente através dos botões e display de calibração, buscando colocar o motor em funcionamento e manter a marcha lenta estável a $900 \mathrm{rpm}$, com variação inferior a 100 rpm. Para analisar a estequiometria da mistura, foi feita a leitura da tensão da sonda lambda através de um voltímetro comum. Considerando que valores de tensão entre $400 \mathrm{mV}$ a $600 \mathrm{mV}$ representam uma mistura ideal, a marcha lenta se manteve estável e a mistura estequiométrica para valores do Fci entre 1,01 e 1,13.

Buscando encontrar o valor ideal do Fci, valores entre 1,01 e 1,13 foram testados com o veículo em movimento com rotação até $5000 \mathrm{rpm}$, onde a mistura de mostrou estequiométrica para valores entre 1,03 e 1,07, onde ficou definido como 1,05 o melhor valor para Fci.

Após a calibração do GNV, a variável $M G_{g n v}$ pode ser alterada, permitindo o uso de misturas de GNV e etanol.

Devido a problemas mecânicos sucessivos no Daewoo Lanos e sua baixa disponibilidade de peças de reposição, os ensaios dinamométricos foram feitos somente no VW Gol, que por ser um veículo novo, o desgaste natural do veículo não influencia nos testes e permite que os ensaios de potência máxima sejam feitos com baixo risco de quebra no motor.

\subsubsection{Calibração do VW gol para uso do GNV}

Semelhante ao calibração do Daewoo Lanos, a estratégia de calibração consiste em alterar a porcentagem de combustível em relação ao tempo de injeção original do veículo e aguardar cerca de 30 segundos para que o sistema em malha fechada atue corretamente e faça a correção da mistura, encontrando a estequiometria da mistura ar-combustível.

Alterando o valor do Fci e observando o sinal da sonda lambda, o Fci se apresentou ideal para valores entre 0,6 a 0,8 onde foi considerado o valor intermediário de 0,7 .

Para confirmar a funcionalidade da metodologia de calibração através da leitura da sonda lambda, foram feitos ensaios dinamométricos com vários valores de Fci, buscando os melhores valores para a máxima e potência média para rotações de 2000 a $5000 \mathrm{rpm}$.

A potência máxima obtida foi com o valor de $\mathrm{Fci}=0,8$. Contudo, analisando a potência média e potência máxima na faixa de rotação entre 2000 a 5000, rpm foram obtidos melhores resultados quando aplicado o valor de Fci $=0,7$, de acordo com a Tabela 13 e o Gráfico 5. O 
ganho de potência com o aumento do Fci foi até o limite de 0,7 , passando a perda de potência com 0,75 .

Tabela 13 - Calibração do Fci [33].

\begin{tabular}{|c|c|c|c|c|c|c|}
\hline \multirow[t]{2}{*}{ Fci } & \multicolumn{2}{|c|}{ Potência Máxima } & \multicolumn{2}{|c|}{$\begin{array}{l}\text { Potência Máxima } \\
\text { (2000 a } 5000 \text { rpm) }\end{array}$} & \multicolumn{2}{|c|}{$\begin{array}{l}\text { Potência Média } \\
\text { (2000 a } 5000 \text { rpm) }\end{array}$} \\
\hline & $\mathrm{CV}$ & KW & $\mathrm{CV}$ & KW & $\mathrm{CV}$ & KW \\
\hline $\mathbf{0 , 5 0}$ & 47,11 & 35,13 & 47,11 & 35,13 & 34,51 & 25,73 \\
\hline 0,65 & 48,72 & 36,33 & 46,51 & 34,68 & 34,48 & 25,71 \\
\hline $\mathbf{0 , 7 0}$ & 51,82 & 38,64 & 50,21 & 37,44 & 37,46 & 27,93 \\
\hline 0,75 & 51,32 & 38,27 & 49,90 & 37,21 & 36,86 & 27,49 \\
\hline $\mathbf{0 , 8 0}$ & 52,83 & 39,40 & 46,21 & 34,46 & 35,70 & 26,62 \\
\hline Etanol & 64,06 & 47,77 & 62,26 & 46,43 & 45,20 & 33,71 \\
\hline
\end{tabular}

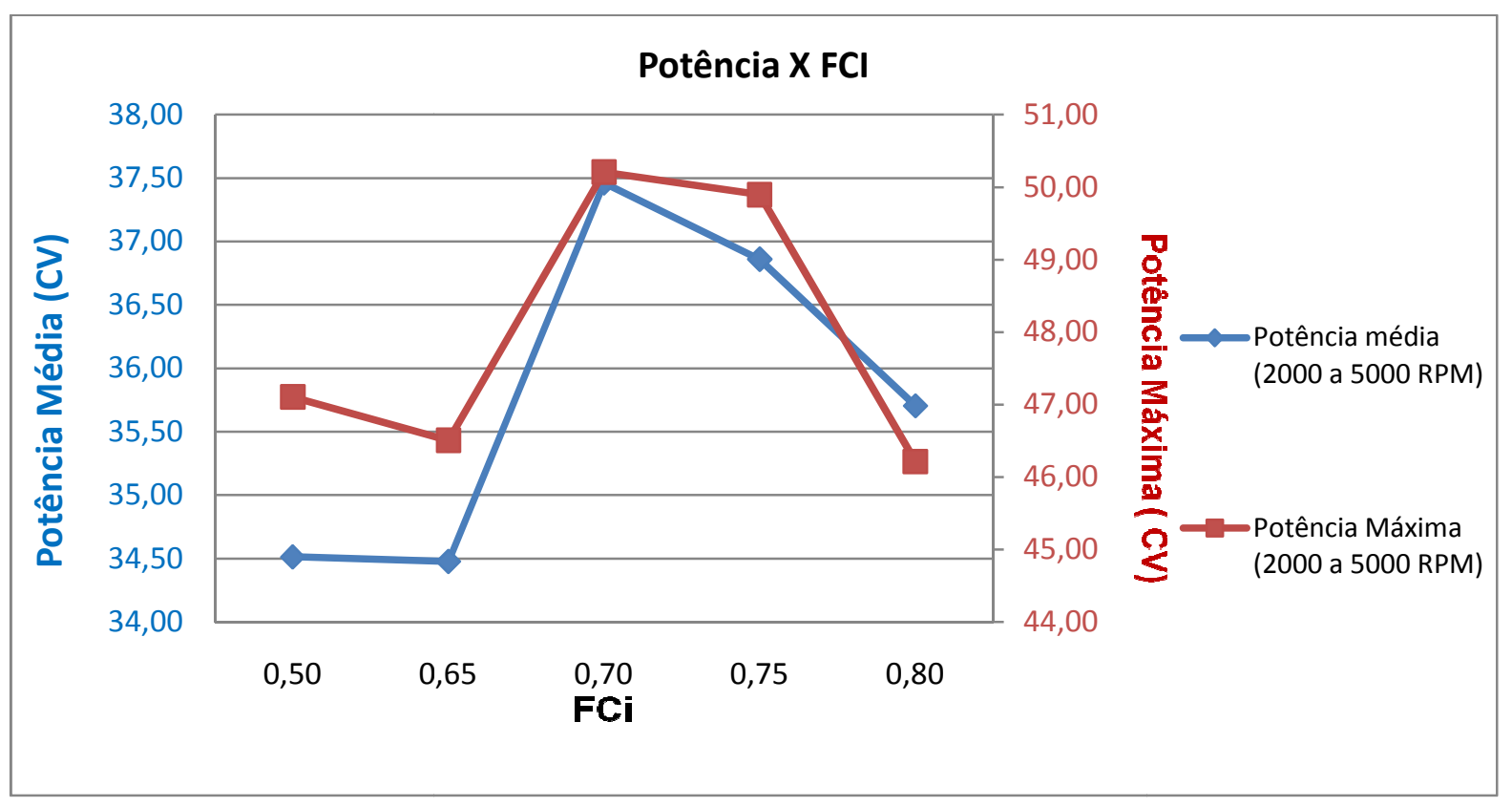

Gráfico 5 - Potência X FCI[33].

No Gráfico 6, é apresentada a potência com diversos valor de FCI onde observa-se que o melhor valor obtido foi o de 0,7 , ou $70 \%$. Na mesma tabela, foi utilizada a medida de referência com $100 \%$ de etanol. 


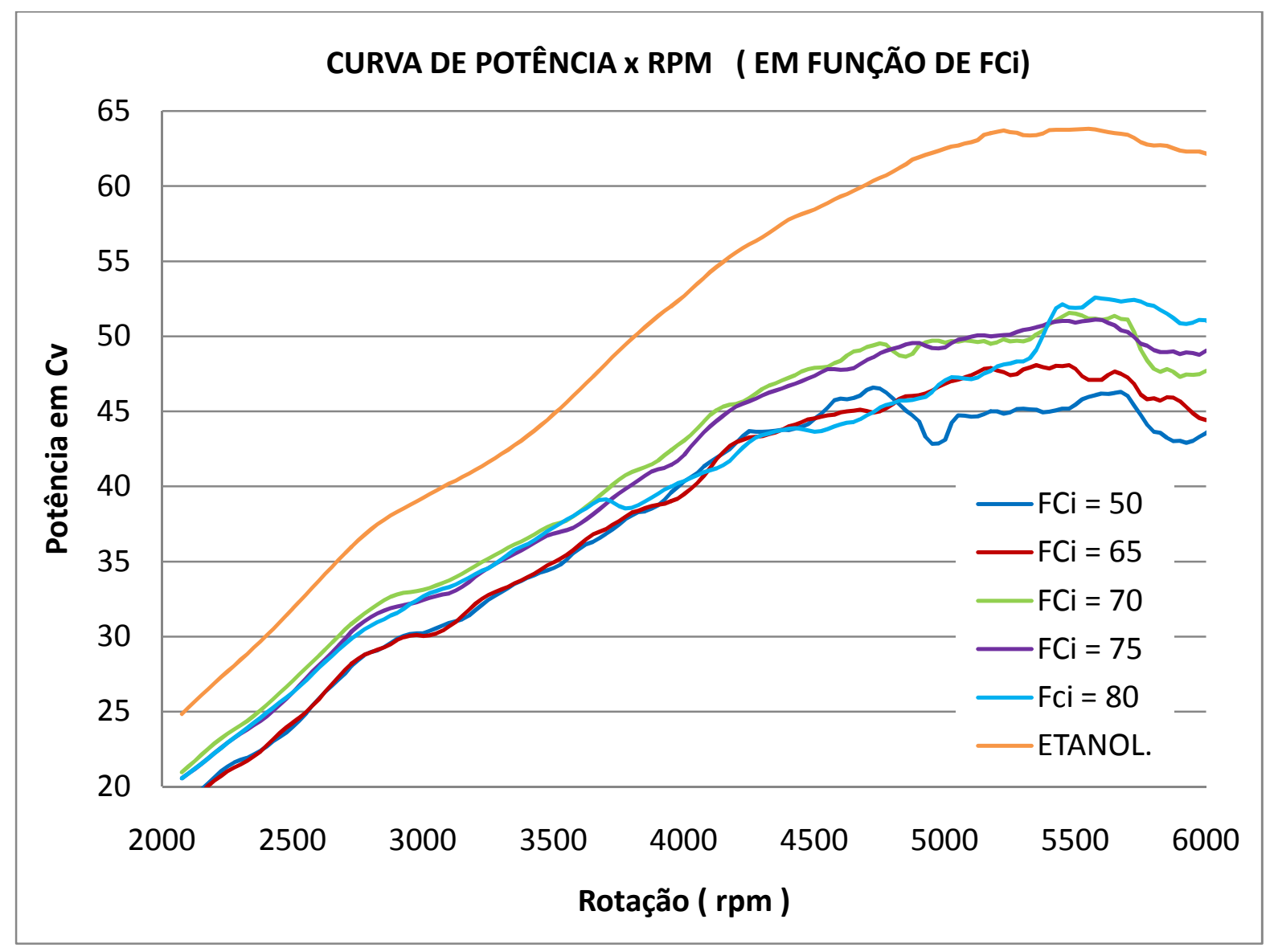

Gráfico 6 - Calibração do Fci[33].

Tabela 14 - Comparação entre potências utilizando Etanol e GNV[33].

\begin{tabular}{ccccc}
\hline & $\begin{array}{c}\mathbf{1 0 0 \%} \\
\text { Etanol } \\
\text { CV(Kw) }\end{array}$ & $\begin{array}{c}\mathbf{1 0 0 \%} \\
\text { GNV } \\
\text { CV(Kw) }\end{array}$ & $\begin{array}{c}\text { Potência } \\
\text { Perdida } \\
\text { CV(Kw) }\end{array}$ & $\begin{array}{c}\text { PERDA de } \\
\text { Potência (\%) }\end{array}$ \\
\hline $\begin{array}{c}\text { Potência máxima } \\
\text { até 5000 rpm }\end{array}$ & $62,26(46,42)$ & $50,21(37,44)$ & $12,05(8,98)$ & 19,35 \\
Potência média & $45,20(33,70)$ & $37,46(27,93)$ & $7,74(5,77)$ & 17,12 \\
Potencia máxima & $64,06(47,76)$ & $51,82(38,64)$ & $12,24(9,12)$ & 19,11
\end{tabular}

Uma comparação entre a potência do motor utilizando etanol e GNV é apresentada na tabela 14, onde se observa perda de potência média de 17,12\% quando utilizado GNV. Esse efeito já era esperado devido à menor eficiência energética do GNV. No Gráfico 7, observa-se a perda de potência com o aumento da rotação do motor. 


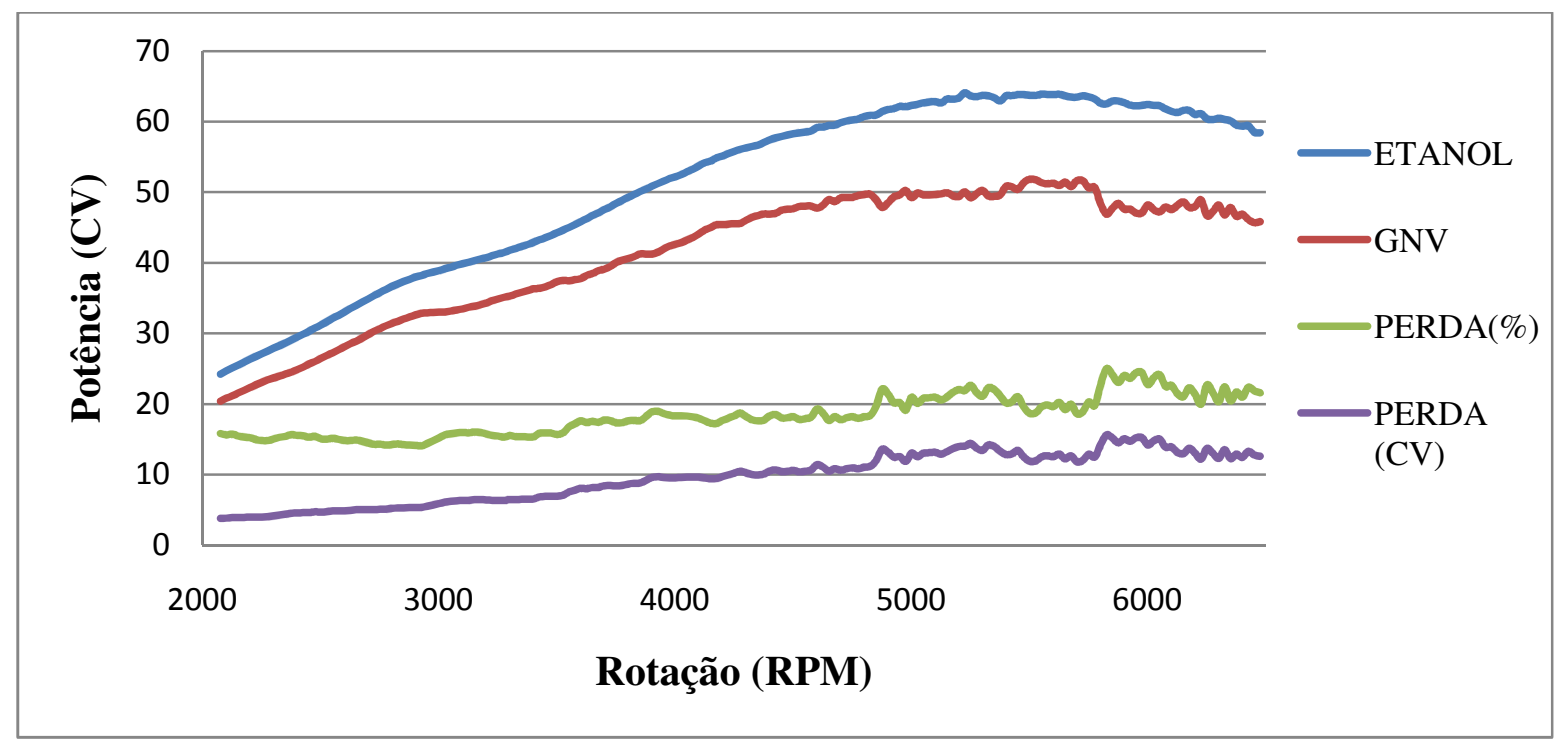

Gráfico 7 - Potência GNV e Etanol[33].

Com o tempo de injeção já calibrado, o outro parâmetro que influencia no rendimento e potência é o ponto de ignição.

A ECU utiliza o sinal do sensor de detonação para correção da curva de ignição. Quando o GNV é instalado, o ponto de ignição deve ser adiantado para um melhor rendimento. Comercialmente, existem diversos modelos de equipamentos para corrigir o avanço quando utilizado o GNV.

Em todas as gerações de conversão, são instalados esses controladores, que adicionam um valor fixo no avanço apartir da curva de avanço original, controlada pela ECU.

Para avaliar a necessidade de introduzir um variador de avanço, foi escolhido um modelo com 4 configurações de avanço possíveis, respectivamente, $6^{\circ}, 9^{\circ}, 12^{\circ}, 15^{\circ}$. No Gráfico 8 , são apresentadas as curvas de potência utilizando as configurações disponíveis no variador de avanço, apontando que a melhor configuração foi a não utilização do variador, demonstando que a ECU do veículo é capaz de encontrar a melhor configuração de avanço quando utilizado $100 \%$ de GNV.

Embora tenha ficado evidente que o uso do variador de avanço não traz ganho de potência quando utilizado GNV, não se pode concluir que o mesmo se repete ao utilizar simultaneamente GNV e Etanol . No capítulo seguinte, o uso do variador de avanço será novamente avaliado para uso de misturas de Etanol e GNV. 


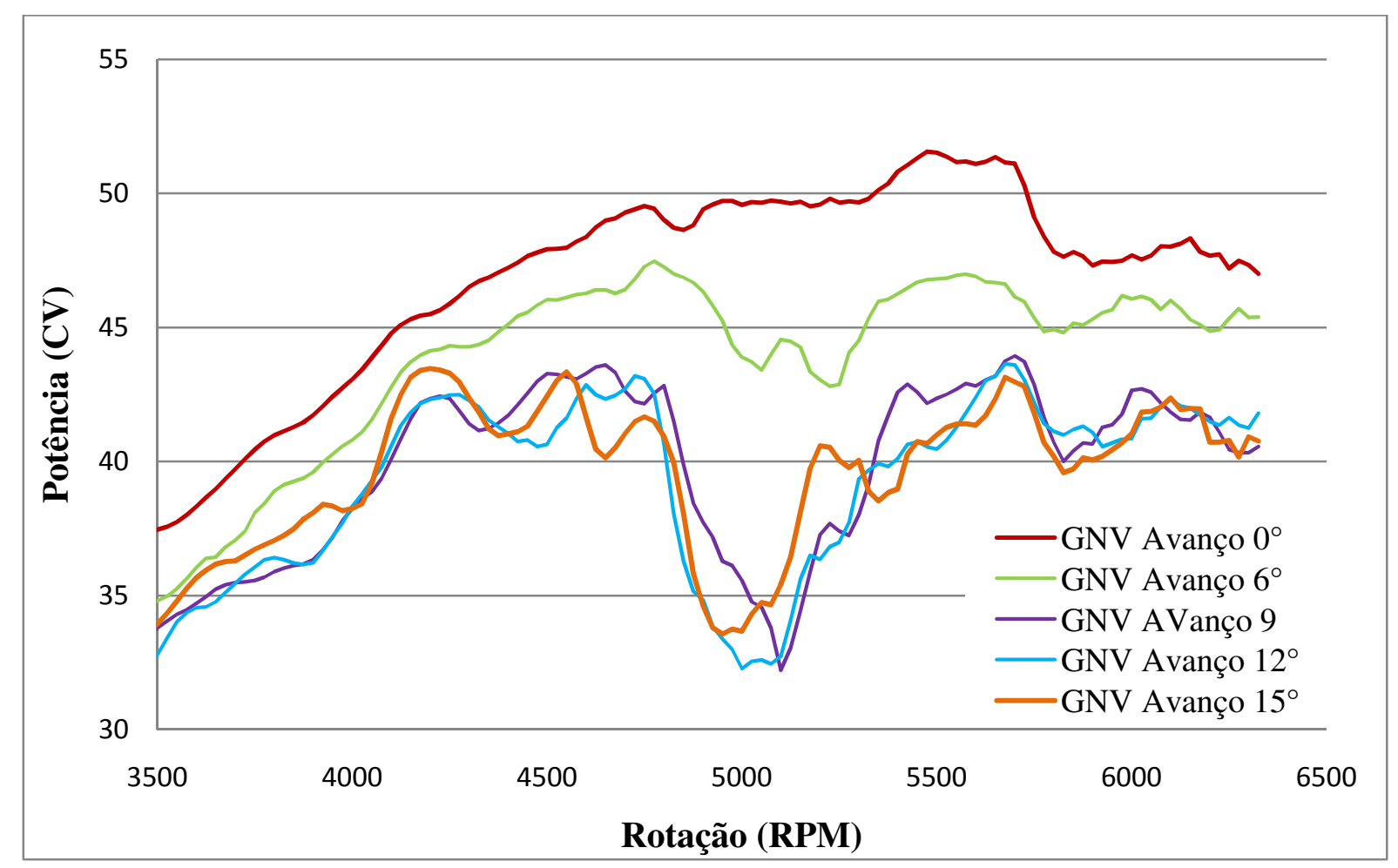

Gráfico 8 - Variação de Avanço[33].

\subsubsection{Calibração do VW Gol para uso do GNV e etanol simultâneo}

Para avaliar as vantagens do uso de GNV e etanol simultaneamente foram realizados ensaios dinamométricos com diferentes proporções dos combustíveis e diferentes configurações de avanço, sendo 6 estados possíveis para o ajuste da mistura e 5 estados para ajuste do variador de avanço, conforme a Tabela 15 e Tabela 16.

Tabela 15 - Definição dos Estados de configuração de mistura de GNV e Etanol[33].

\begin{tabular}{ccc}
\hline Estados & GNV ( \%) & Etanol (\%) \\
\hline $\mathbf{1}$ & 0 & 100 \\
$\mathbf{2}$ & 20 & 80 \\
$\mathbf{3}$ & 40 & 60 \\
$\mathbf{4}$ & 60 & 40 \\
$\mathbf{5}$ & 80 & 20 \\
$\mathbf{6}$ & 100 & 0 \\
\hline
\end{tabular}


Tabela 16 - Configuração do Variador de Avanço[33].

\begin{tabular}{cc}
\hline Estados & Avanço (graus) \\
\hline $\mathbf{1}$ & 0 \\
$\mathbf{2}$ & 6 \\
$\mathbf{3}$ & 9 \\
$\mathbf{4}$ & 12 \\
$\mathbf{5}$ & 15 \\
\hline
\end{tabular}

Fazendo a interpolação dos dados da Tabela 15 e Tabela 16, obtêm-se um total de 30 opções de ajuste, que definiram o roteiro para os ensaios dinamométricos, apresentado na Tabela 17.

Tabela 17 - Configurações de misturas de combustíveis e do variador de avanço[33].

\begin{tabular}{ccc}
\hline GNV $(\boldsymbol{\%})$ & Etanol (\%) & Avanço (Graus) \\
\hline $\mathbf{0}$ & 100 & 0 \\
$\mathbf{2 0}$ & 80 & 0 \\
$\mathbf{4 0}$ & 60 & 0 \\
$\mathbf{6 0}$ & 40 & 0 \\
$\mathbf{8 0}$ & 20 & 0 \\
$\mathbf{1 0 0}$ & 0 & 0 \\
$\mathbf{0}$ & 100 & 6 \\
$\mathbf{2 0}$ & 80 & 6 \\
$\mathbf{4 0}$ & 60 & 6 \\
$\mathbf{6 0}$ & 40 & 6 \\
$\mathbf{8 0}$ & 20 & 6 \\
$\mathbf{1 0 0}$ & 0 & 6 \\
$\mathbf{0}$ & 100 & 9 \\
$\mathbf{2 0}$ & 80 & 9 \\
$\mathbf{4 0}$ & 60 & 9 \\
$\mathbf{6 0}$ & 40 & 9 \\
$\mathbf{8 0}$ & 20 & 9 \\
$\mathbf{1 0 0}$ & 0 & 9 \\
$\mathbf{0}$ & 100 & 12 \\
$\mathbf{2 0}$ & 80 & 12 \\
$\mathbf{4 0}$ & 60 & 12 \\
$\mathbf{6 0}$ & 40 & 12 \\
$\mathbf{8 0}$ & 20 & 12 \\
$\mathbf{1 0 0}$ & 0 & 12 \\
$\mathbf{0}$ & 100 & 15 \\
$\mathbf{2 0}$ & 80 & 15 \\
$\mathbf{4 0}$ & 60 & 15 \\
$\mathbf{6 0}$ & 40 & 15 \\
$\mathbf{8 0}$ & 20 & \\
$\mathbf{1 0 0}$ & 0 & \\
\hline & & 6 \\
\hline
\end{tabular}


Utilizando o software de estatística Minitab, foram analisados os dados de potência em função da mistura dos combustíveis e configuração de avanço, conforme Gráfico 9, onde se observa que a potência aumenta com o aumento da porcentagem de Etanol na mistura.

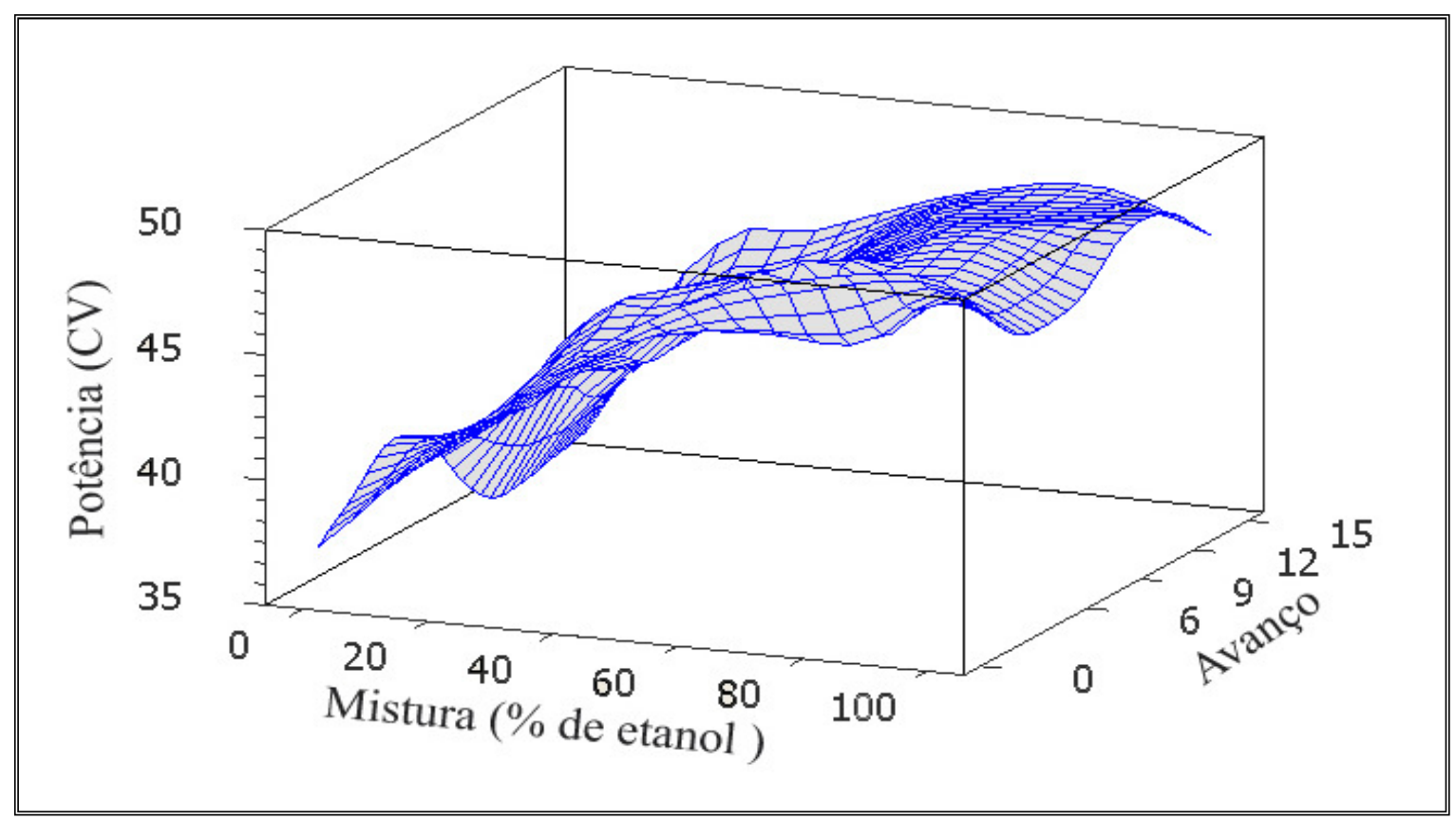

Gráfico 9 - Potência X MisturaX Correção do avanço [33].

Para uma análise mais detalhada, foi analisada a potência média por faixa de rotação com intervalos de $500 \mathrm{rpm}$, com as variações de porcentagem de etanol e GNV, indicando a melhor configuração de avanço encontrada.

No Gráfico 9, observa-se que a potência é influenciada pela quantidade de etanol na mistura e que o avanço não tem influência significativa.

Tabela 18 - Potência, avanço e mistura em \%, para uma rotação média de 2000 a 2500 rpm [33].

\begin{tabular}{ccccccc}
\hline $\begin{array}{c}\text { Mistura } \\
\text { (\% de etanol) }\end{array}$ & $\begin{array}{c}\text { Mistura } \\
\text { (\% de GNV) }\end{array}$ & \multicolumn{2}{c}{ Potência com Avanço } & $\begin{array}{c}\text { Melhor } \\
\text { avanço }\end{array}$ & \multicolumn{2}{c}{$\begin{array}{c}\text { Potência } \\
\text { (sem avanço) }\end{array}$} \\
\hline $\mathbf{0}$ & 100 & 23,60 & 17,60 & 6 & 21,00 & 15,66 \\
$\mathbf{2 0}$ & 80 & 23,99 & 17,89 & 9 & 23,10 & 17,23 \\
$\mathbf{4 0}$ & 60 & 30,08 & 22,43 & 0 & 30,08 & 22,43 \\
$\mathbf{6 0}$ & 40 & 25,93 & 19,34 & 0 & 25,93 & 19,34 \\
$\mathbf{8 0}$ & 20 & 26,60 & 19,84 & 9 & 26,34 & 19,64 \\
$\mathbf{1 0 0}$ & 0 & 27,48 & 20,49 & 0 & 27,48 & 20,49 \\
\hline
\end{tabular}


Na Tabela 18, é apresentada a potência média encontrada em diferentes proporções de etanol e GNV, indicando qual a configuração de avanço que resultou maior potência na faixa de rotação entre 2000 a $2500 \mathrm{rpm}$.

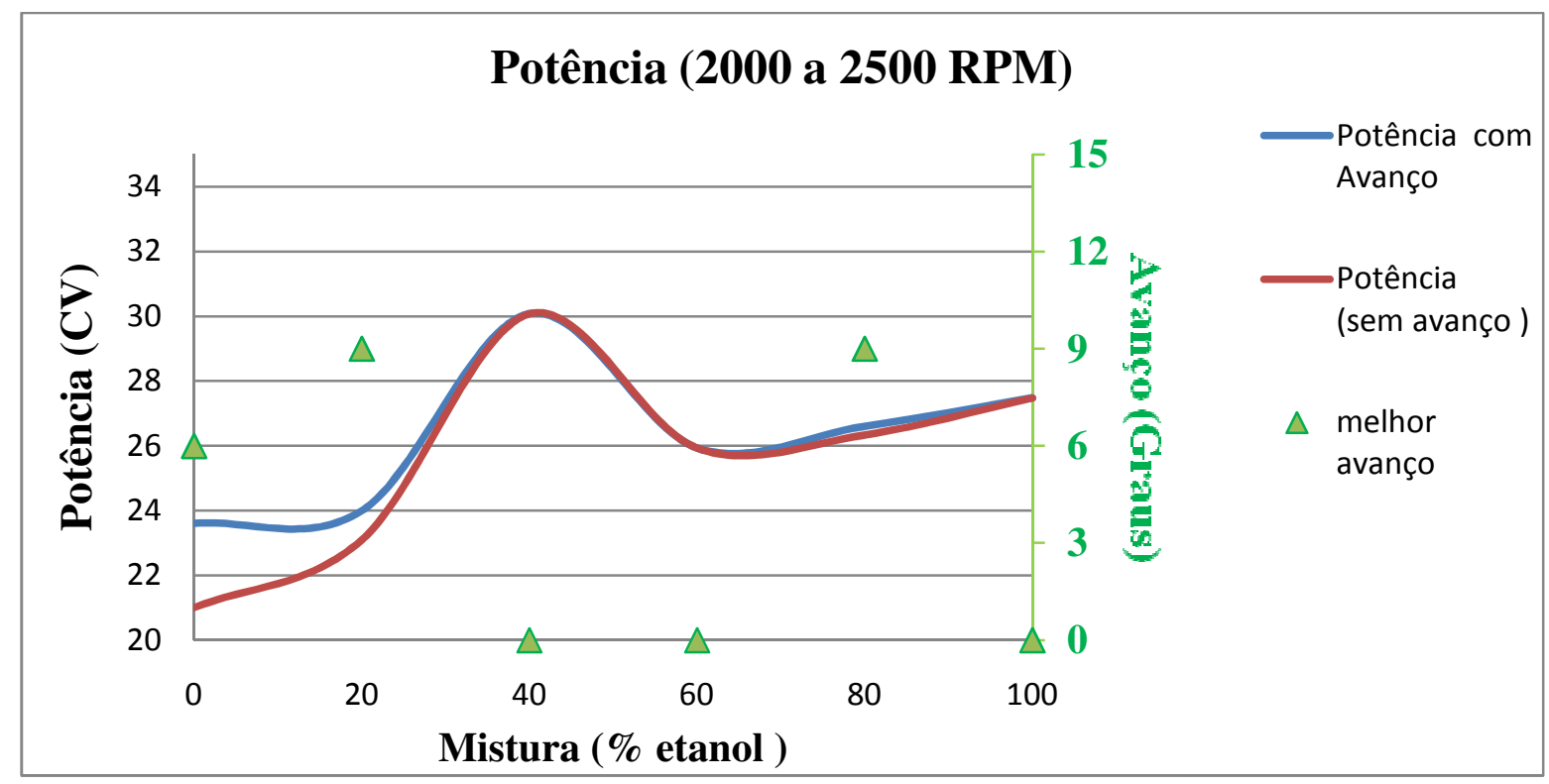

Gráfico 10 - Potência, avanço e mistura em \%, para uma rotação média de 2000 a 2500 rpm[33].

No Gráfico 10, observam-se as duas curvas de potência. Em vermelho, a curva de potência sem a correção no avanço de ignição. Em azul, com a correção, e o triângulo verde indicando qual a melhor correção de avanço encontrada. Observa-se que o uso do avanço adicional se mostrou eficiente apenas quando utilizado somente GNV e a mistura de $20 \%$ de etanol e $80 \%$ de GNV.

A potência máxima era esperada quando usado $100 \%$ de etanol, devido ao seu maior poder energético. Porém, através do Gráfico 11, observa-se que nessa faixa de rotação a maior potência foi obtida com o uso de $40 \%$ de etanol. 
Tabela 19 - Potência, avanço e mistura em \%, para uma rotação média de 2500 a 3000 rpm[33].

\begin{tabular}{ccccccc}
\hline $\begin{array}{c}\text { Mistura } \\
\text { (\% de } \\
\text { etanol) }\end{array}$ & $\begin{array}{c}\text { Mistura } \\
\text { (\% de } \\
\text { GNV) }\end{array}$ & Potência com Avanço & $\begin{array}{c}\text { Melhor } \\
\text { avanço }\end{array}$ & \multicolumn{2}{c}{$\begin{array}{c}\text { Potência } \\
\text { (sem avanço) }\end{array}$} \\
\cline { 1 - 5 } & & CV & KW & & CV & KW \\
\cline { 1 - 5 } $\mathbf{0}$ & 100 & 26,82 & 20,00 & 6 & 24,46 & 18,24 \\
$\mathbf{2 0}$ & 80 & 27,66 & 20,63 & 9 & 26,68 & 19,90 \\
$\mathbf{4 0}$ & 60 & 32,66 & 24,35 & 0 & 32,66 & 24,35 \\
\hline $\mathbf{6 0}$ & 40 & 29,89 & 22,29 & 0 & 29,89 & 22,29 \\
$\mathbf{8 0}$ & 20 & 30,72 & 22,91 & 9 & 30,26 & 22,56 \\
& 0 & 31,90 & 23,79 & 0 & 31,90 & 23,79 \\
\hline
\end{tabular}

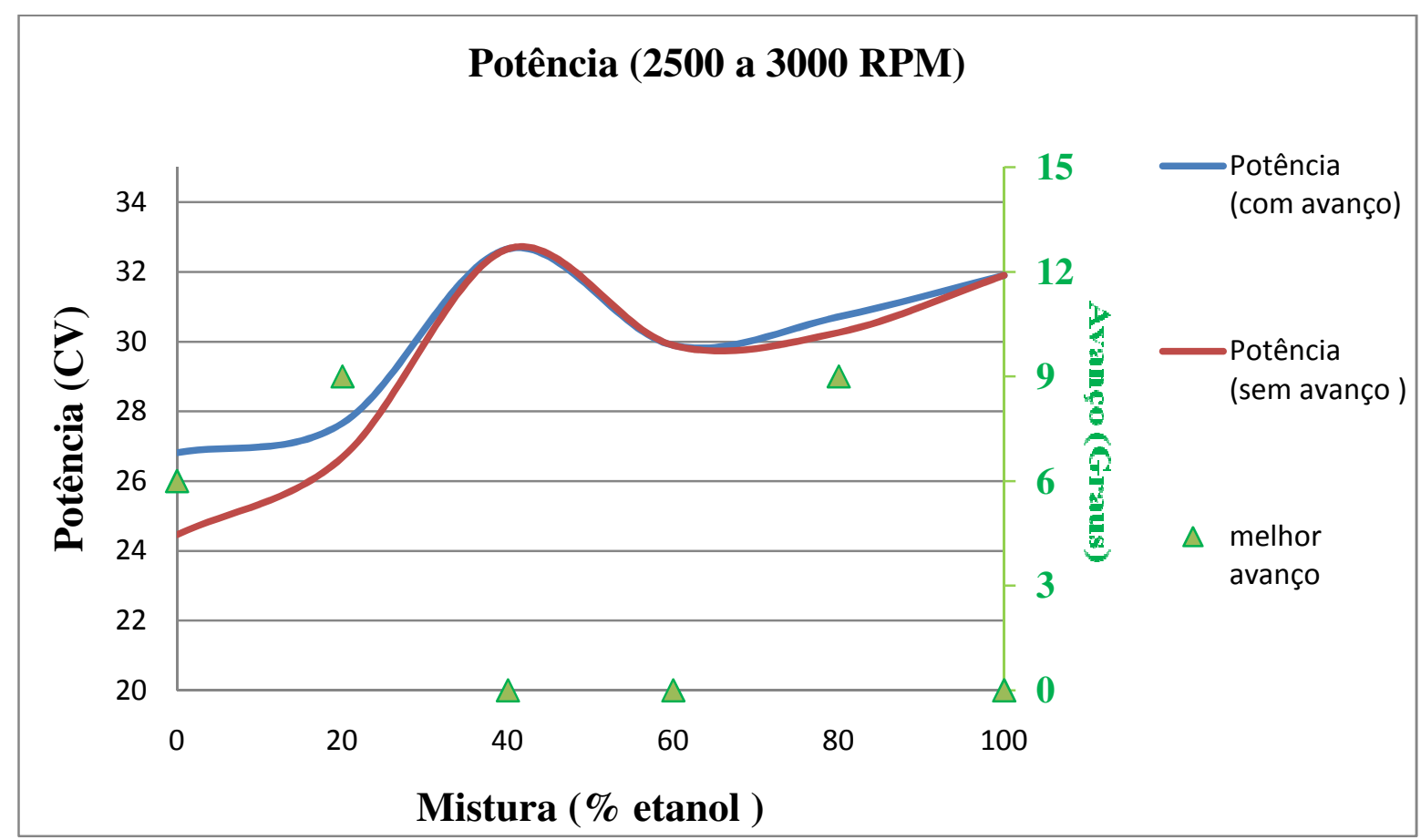

Gráfico 11 - Potência, avanço e mistura em \%, para uma rotação média de 2500 a 3000 rpm[33].

No Gráfico 11 e Tabela 19, a rotação analisada está na faixa de rotação entre 2500 a 3000 rpm. Observa-se o mesmo ocorrido na faixa de rotação anterior, de 2000 a 2500, onde o avanço no ponto de ignição só resulta em pequena melhora na potência quando utilizado somente GNV ou $80 \%$ de GNV e $20 \%$ de etanol . A melhor potência encontrada foi quando utilizado $40 \%$ de etanol e $60 \%$ de GNV.

Na Tabela 20 e no Gráfico 12, é apresentada a potência na faixa de rotação entre 3000 a 3500 rpm, onde observa-se comportamento diferente das faixas anteriores. A melhor configuração 
de avanço encontrada não produz aumento significativo de potência, e a potência máxima foi obtida com o uso de $100 \%$ de etanol.

Tabela 20 - Potência, avanço e mistura em \%, para uma rotação média de 3000 a 3500 rpm [33].

\begin{tabular}{|c|c|c|c|c|c|c|}
\hline \multirow[t]{2}{*}{$\begin{array}{c}\text { Mistura } \\
\text { (\% de etanol) }\end{array}$} & \multirow[t]{2}{*}{$\begin{array}{c}\text { Mistura } \\
\text { (\% de GNV) }\end{array}$} & \multicolumn{2}{|c|}{ Potência com Avanço } & \multirow[t]{2}{*}{$\begin{array}{l}\text { Melhor Correção } \\
\text { de avanço }\end{array}$} & \multicolumn{2}{|c|}{$\begin{array}{c}\text { Potência } \\
\text { (sem avanço) }\end{array}$} \\
\hline & & CV & KW & & CV & KW \\
\hline $\mathbf{0}$ & 100 & 32,87 & 24,51 & 6 & 32,27 & 24,06 \\
\hline 20 & 80 & 36,13 & 26,94 & 9 & 34,91 & 26,03 \\
\hline 40 & 60 & 37,98 & 28,32 & 0 & 37,98 & 28,32 \\
\hline 60 & 40 & 39,09 & 29,14 & 0 & 39,09 & 29,15 \\
\hline 80 & 20 & 39,73 & 29,62 & 9 & 38,88 & 28,99 \\
\hline 100 & 0 & 41,63 & 31,04 & 12 & 41,60 & 31,02 \\
\hline
\end{tabular}

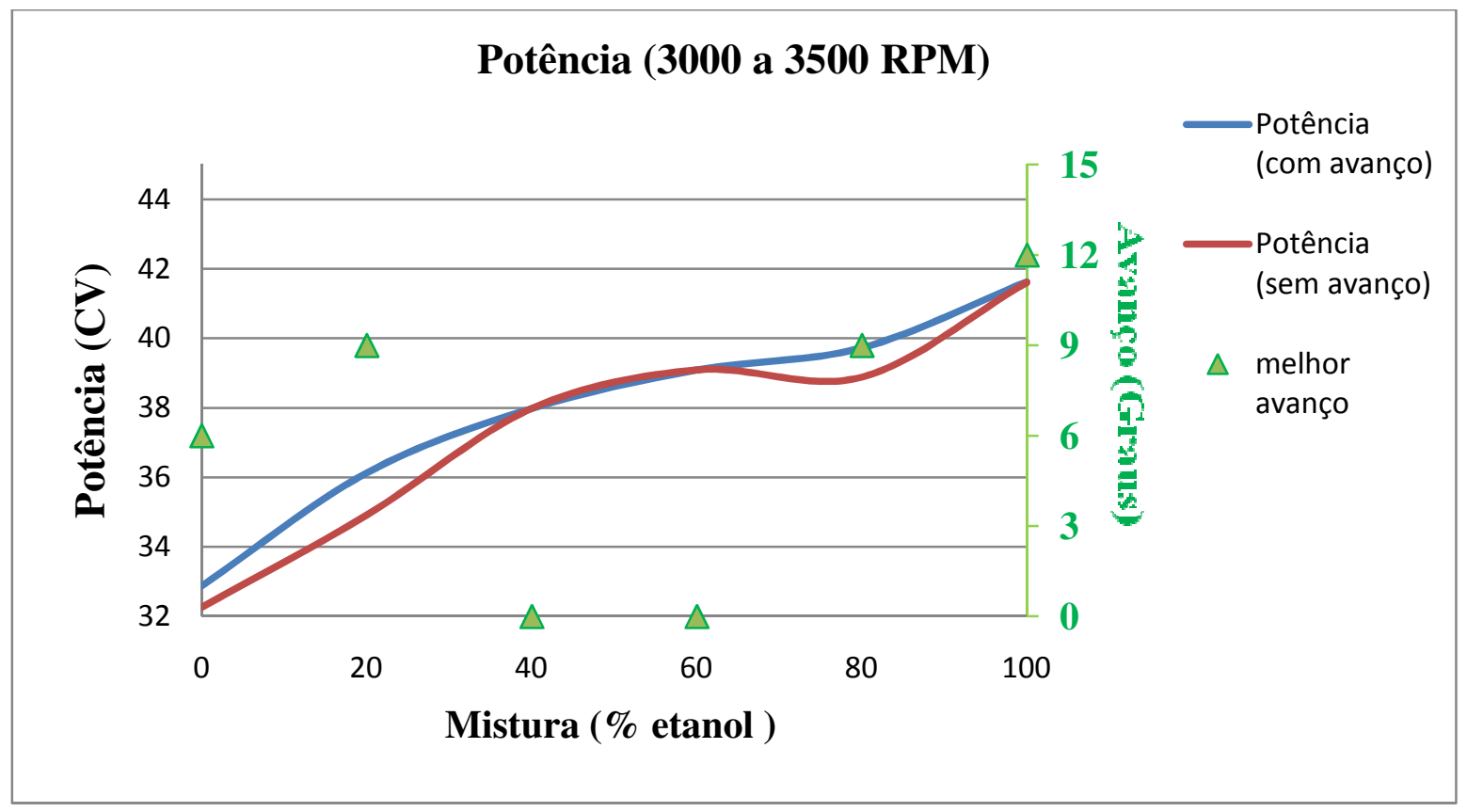

Gráfico 12 - Potência, avanço e mistura em \%, para uma rotação média de 3000 a 3500 rpm[33].

Da Tabela 21 até a Tabela 26 e no Gráfico 13 até o Gráfico 18, são apresentadas as faixas de rotação de 3500 a 6500 rpm, onde todas apresentam comportamento similar à faixa de rotação anterior, com pouca variação de potência quando relacionada ao uso do variador de avanço, e aumento da potência proporcional ao aumento da proporção de etanol. 
Tabela 21 - Potência, avanço e mistura em \%, para uma rotação média de 3500 a 4000 rpm [33].

\begin{tabular}{ccccccc}
\hline $\begin{array}{c}\text { Mistura } \\
\text { (\% de } \\
\text { etanol) }\end{array}$ & $\begin{array}{c}\text { Mistura } \\
\text { (\% de GNV) }\end{array}$ & \multicolumn{2}{c}{$\begin{array}{c}\text { Potência com } \\
\text { Avanço }\end{array}$} & $\begin{array}{c}\text { Melhor } \\
\text { avanço }\end{array}$ & \multicolumn{2}{c}{$\begin{array}{c}\text { Potência } \\
\text { (sem avanço) }\end{array}$} \\
\hline $\mathbf{0}$ & 100 & 37,58 & 28,02 & 6 & CV & KW \\
\hline $\mathbf{2 0}$ & 80 & 41,94 & 31,27 & 15 & 37,09 & 27,66 \\
\hline $\mathbf{4 0}$ & 60 & 43,46 & 32,41 & 6 & 43,16 & 29,79 \\
$\mathbf{6 0}$ & 40 & 45,51 & 33,94 & 6 & 46,63 & 32,18 \\
$\mathbf{8 0}$ & 20 & 46,63 & 34,77 & 12 & 46,30 & 34,77 \\
\hline $\mathbf{1 0 0}$ & 0 & 48,52 & 36,18 & 0 & 48,52 & 36,18 \\
\hline
\end{tabular}

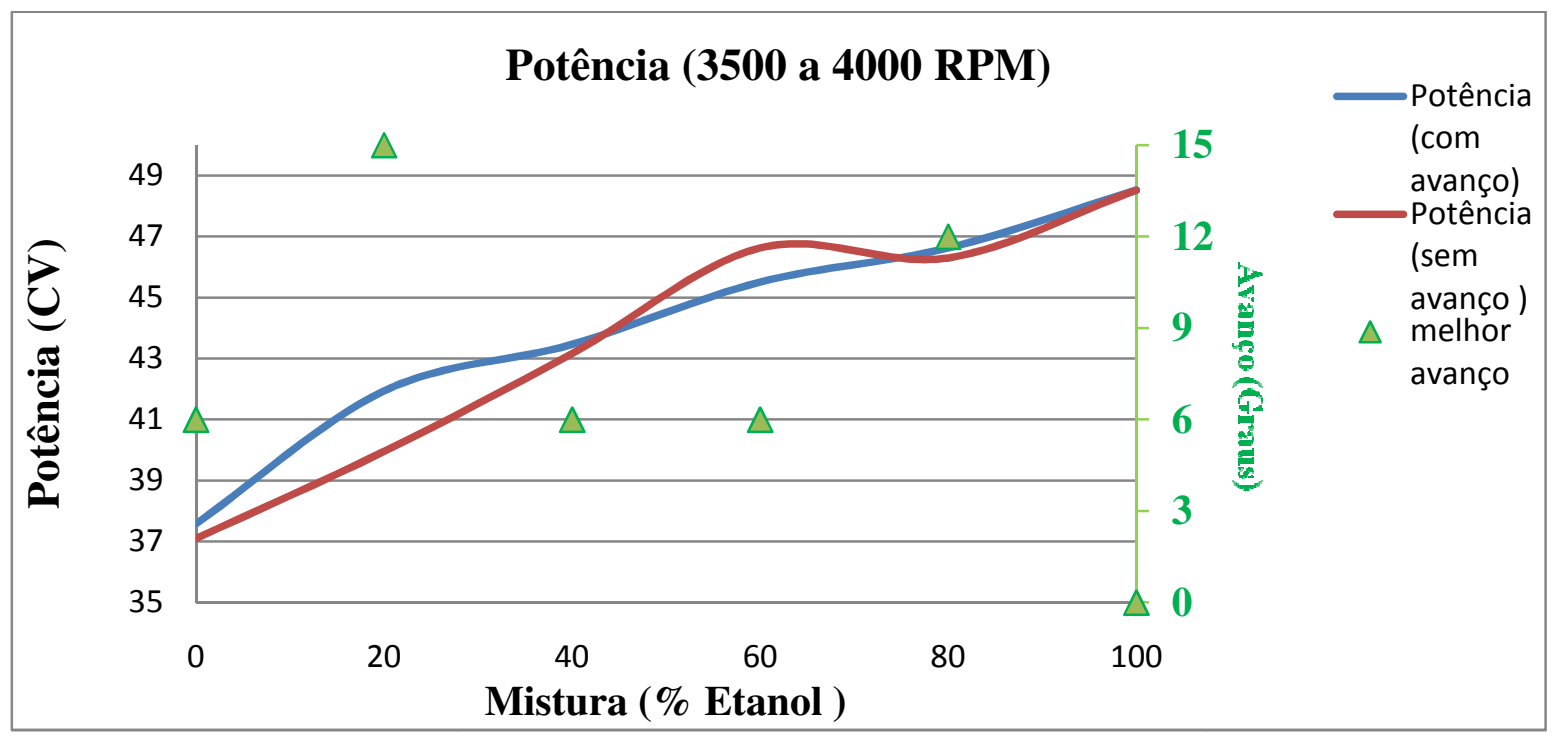

Gráfico 13 - Potência, avanço e mistura em \%, para uma rotação média de 3500 a 4000 rpm[33].

Tabela 22 - Potência, avanço e mistura em \%, para uma rotação média de 4000 a 4500 rpm[33].

\begin{tabular}{ccccccc}
\hline $\begin{array}{c}\text { Mistura } \\
\text { (\% de etanol) }\end{array}$ & $\begin{array}{c}\text { Mistura } \\
\text { (\% de GNV) }\end{array}$ & $\begin{array}{c}\text { Potência com } \\
\text { Avanço }\end{array}$ & \multicolumn{2}{c}{$\begin{array}{c}\text { Melhor correção } \\
\text { de avanço }\end{array}$} & \multicolumn{2}{c}{$\begin{array}{c}\text { Potência } \\
\text { (sem avanço) }\end{array}$} \\
\hline $\mathbf{0}$ & 100 & CV & KW & & CV & KW \\
$\mathbf{2 0}$ & 80 & 43,68 & 32,57 & 6 & 42,69 & 31,83 \\
$\mathbf{4 0}$ & 60 & 50,65 & 36,28 & 15 & 45,79 & 34,15 \\
$\mathbf{6 0}$ & 40 & 52,27 & 37,46 & 15 & 49,52 & 36,93 \\
$\mathbf{8 0}$ & 20 & 53,98 & 40,25 & 12 & 53,24 & 38,98 \\
$\mathbf{1 0 0}$ & 0 & 55,56 & 41,43 & 0 & 55,56 & 41,43 \\
\hline
\end{tabular}




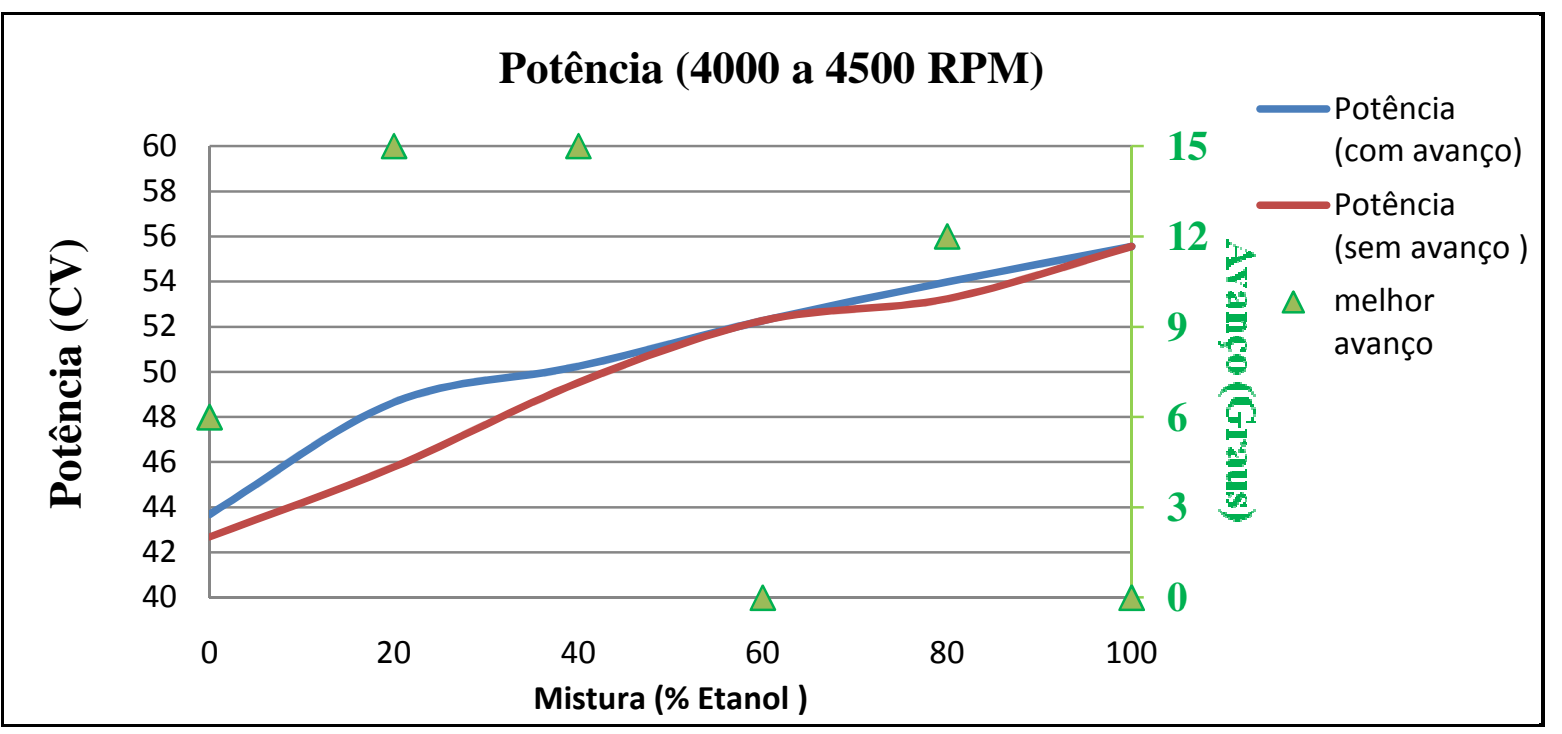

Gráfico 14 - Potência, avanço e mistura em \%, para uma rotação média de 4000 a 4500 rpm [33].

Tabela 23 - Potência, avanço e mistura em \%, para uma rotação média de 4500 a 5000 rpm[33].

\begin{tabular}{ccccccc}
\hline $\begin{array}{c}\text { Mistura } \\
\text { (\% de } \\
\text { etanol) }\end{array}$ & $\begin{array}{c}\text { Mistura } \\
\text { (\% de } \\
\text { GNV) }\end{array}$ & Potência com Avanço & $\begin{array}{c}\text { Melhor } \\
\text { avanço }\end{array}$ & \multicolumn{2}{c}{$\begin{array}{c}\text { Potência } \\
\text { (sem avanço) }\end{array}$} \\
\hline & & CV & KW & & CV & KW \\
\hline $\mathbf{0}$ & 100 & 46,45 & 34,64 & 6 & 45,21 & 33,71 \\
$\mathbf{2 0}$ & 80 & 52,27 & 38,98 & 15 & 49,65 & 37,02 \\
$\mathbf{4 0}$ & 60 & 53,88 & 40,18 & 9 & 53,39 & 39,81 \\
$\mathbf{6 0}$ & 40 & 56,60 & 42,21 & 6 & 56,46 & 42,10 \\
$\mathbf{8 0}$ & 20 & 57,94 & 43,21 & 12 & 57,55 & 42,91 \\
$\mathbf{1 0 0}$ & 0 & 60,36 & 45,01 & 0 & 60,36 & 45,01 \\
\hline
\end{tabular}

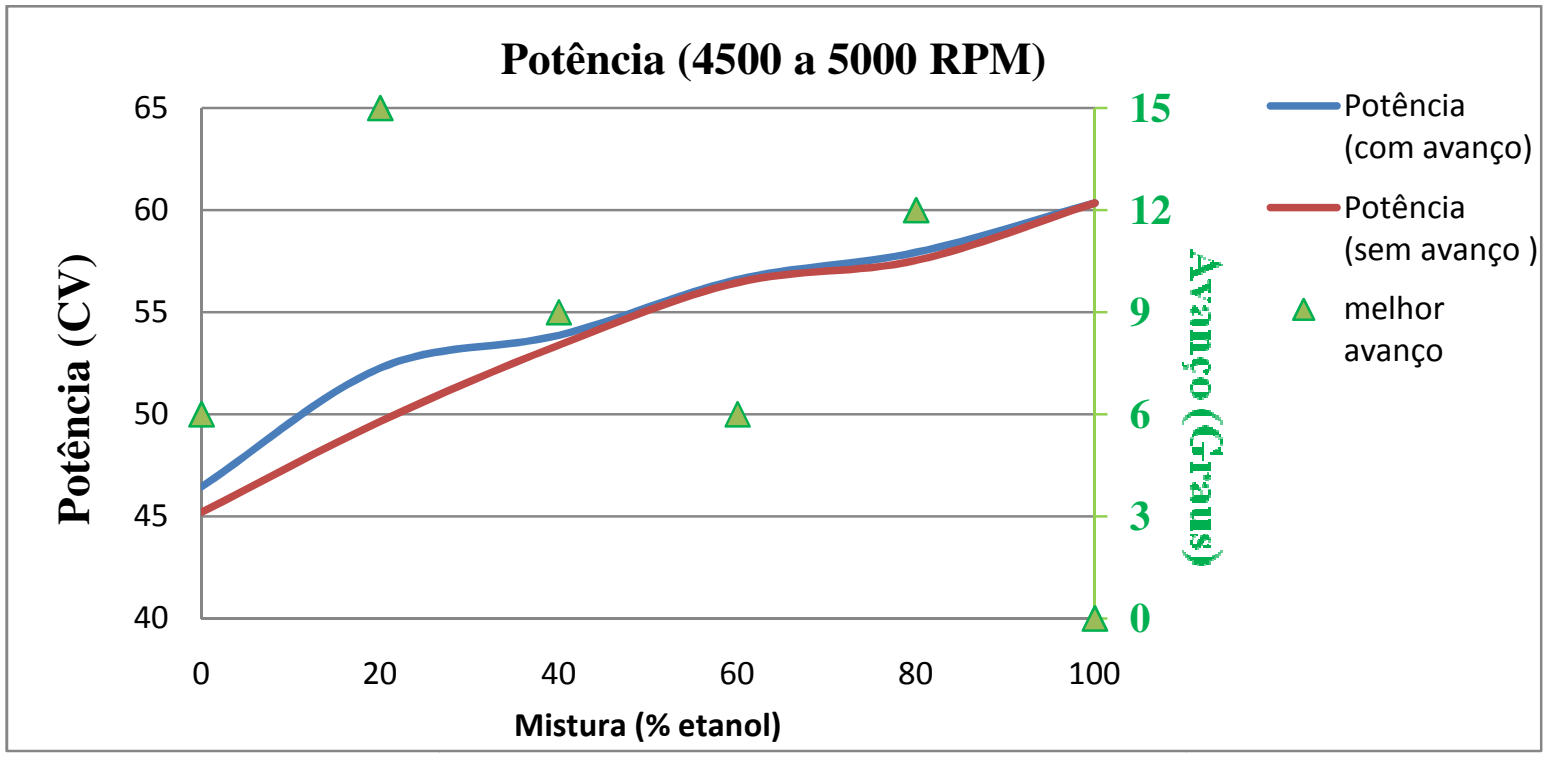

Gráfico 15 - Potência, avanço e mistura em \%, para uma rotação média de 4500 a 5000 rpm [33]. 
Tabela 24 - Potência, avanço e mistura em \%, para uma rotação média de 5000 a 5500 rpm [33].

\begin{tabular}{|c|c|c|c|c|c|c|}
\hline \multirow{2}{*}{ 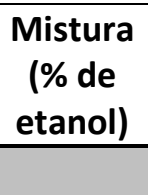 } & \multirow{2}{*}{$\begin{array}{c}\text { Mistura } \\
\text { (\% de } \\
\text { GNV) }\end{array}$} & \multicolumn{2}{|c|}{ Potência com Avanço } & \multirow[t]{2}{*}{$\begin{array}{l}\text { Melhor } \\
\text { avanço }\end{array}$} & \multicolumn{2}{|c|}{$\begin{array}{c}\text { Potência } \\
\text { (sem avanço) }\end{array}$} \\
\hline & & $\mathrm{CV}$ & $\mathrm{KW}$ & & $\mathrm{CV}$ & KW \\
\hline $\mathbf{0}$ & 100 & 44,79 & 33,40 & 0 & 44,79 & 33,40 \\
\hline 20 & 80 & 52,81 & 39,38 & 9 & 51,71 & 38,56 \\
\hline 40 & 60 & 56,10 & 41,83 & 9 & 55,42 & 41,33 \\
\hline 60 & 40 & 58,59 & 43,69 & 6 & 58,47 & 43,60 \\
\hline 80 & 20 & 59,94 & 44,70 & 6 & 59,89 & 44,66 \\
\hline 100 & 0 & 63,31 & 47,21 & 0 & 63,31 & 47,21 \\
\hline
\end{tabular}

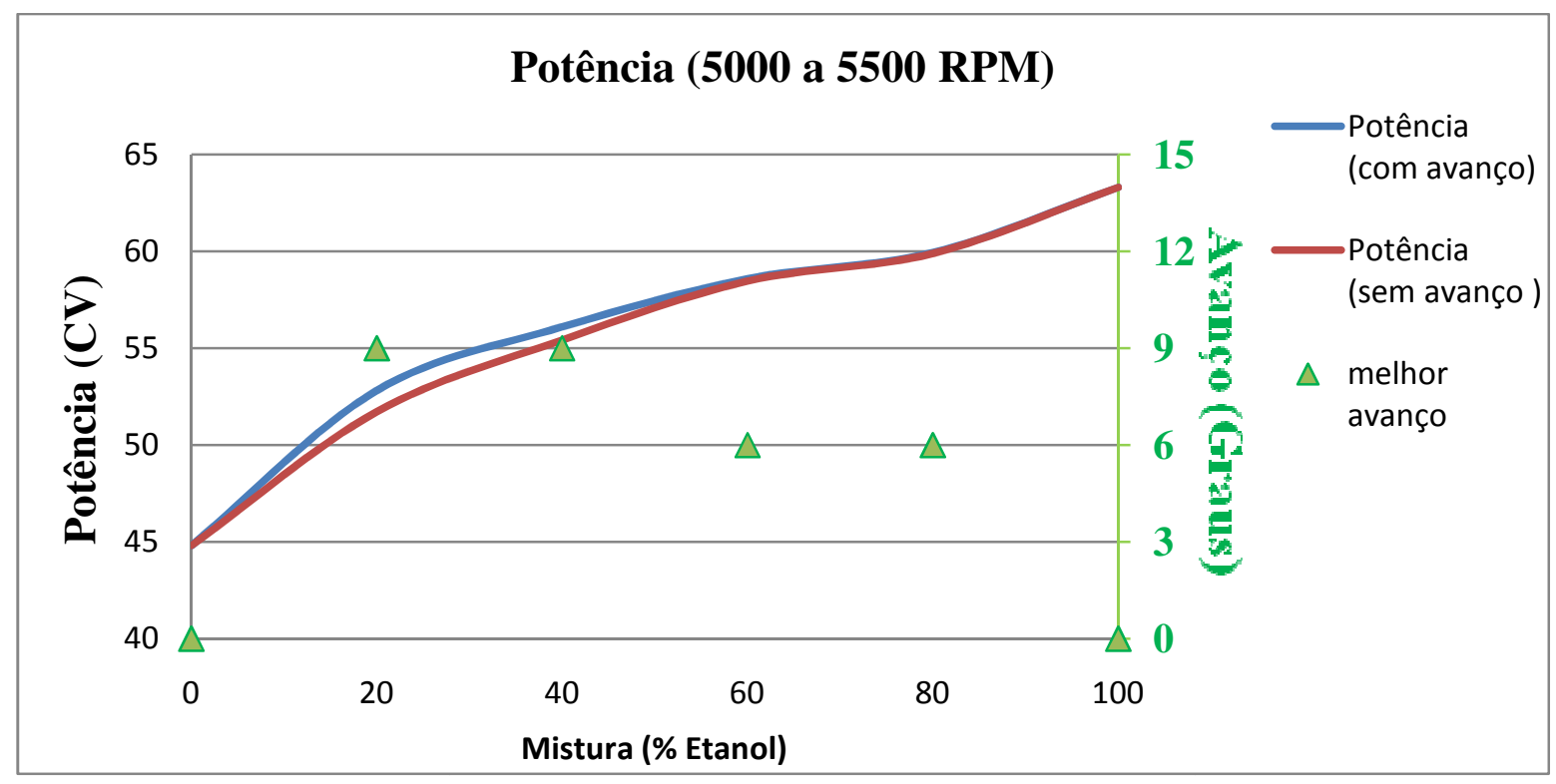

Gráfico 16 - Potência, avanço e mistura em \%, para uma rotação média de 5000 a 5500 rpm [33].

Tabela 25 - Potência, avanço e mistura em \%, para uma rotação média de 5500 a 6000 rpm [33].

\begin{tabular}{ccccccc}
\hline $\begin{array}{c}\text { Mistura } \\
\text { (\% de etanol) }\end{array}$ & $\begin{array}{c}\text { Mistura } \\
\text { (\% de GNV) }\end{array}$ & \multicolumn{2}{c}{$\begin{array}{c}\text { Potência com } \\
\text { Avanço }\end{array}$} & \multicolumn{2}{c}{$\begin{array}{c}\text { Melhor } \\
\text { avanço }\end{array}$} & \multicolumn{2}{c}{$\begin{array}{c}\text { Potência } \\
\text { (sem avanço) }\end{array}$} \\
\hline & & CV & KW & & CV & KW \\
\hline $\mathbf{0}$ & 100 & 45,97 & 34,28 & 6 & 44,77 & 33,38 \\
$\mathbf{2 0}$ & 80 & 53,38 & 39,81 & 15 & 52,30 & 39,00 \\
$\mathbf{4 0}$ & 60 & 55,53 & 41,41 & 15 & 55,43 & 41,33 \\
$\mathbf{6 0}$ & 40 & 58,29 & 43,47 & 6 & 58,20 & 43,40 \\
$\mathbf{8 0}$ & 20 & 59,43 & 44,32 & 9 & 58,00 & 43,25 \\
$\mathbf{1 0 0}$ & 0 & 63,13 & 47,08 & 0 & 63,13 & 47,08 \\
\hline
\end{tabular}




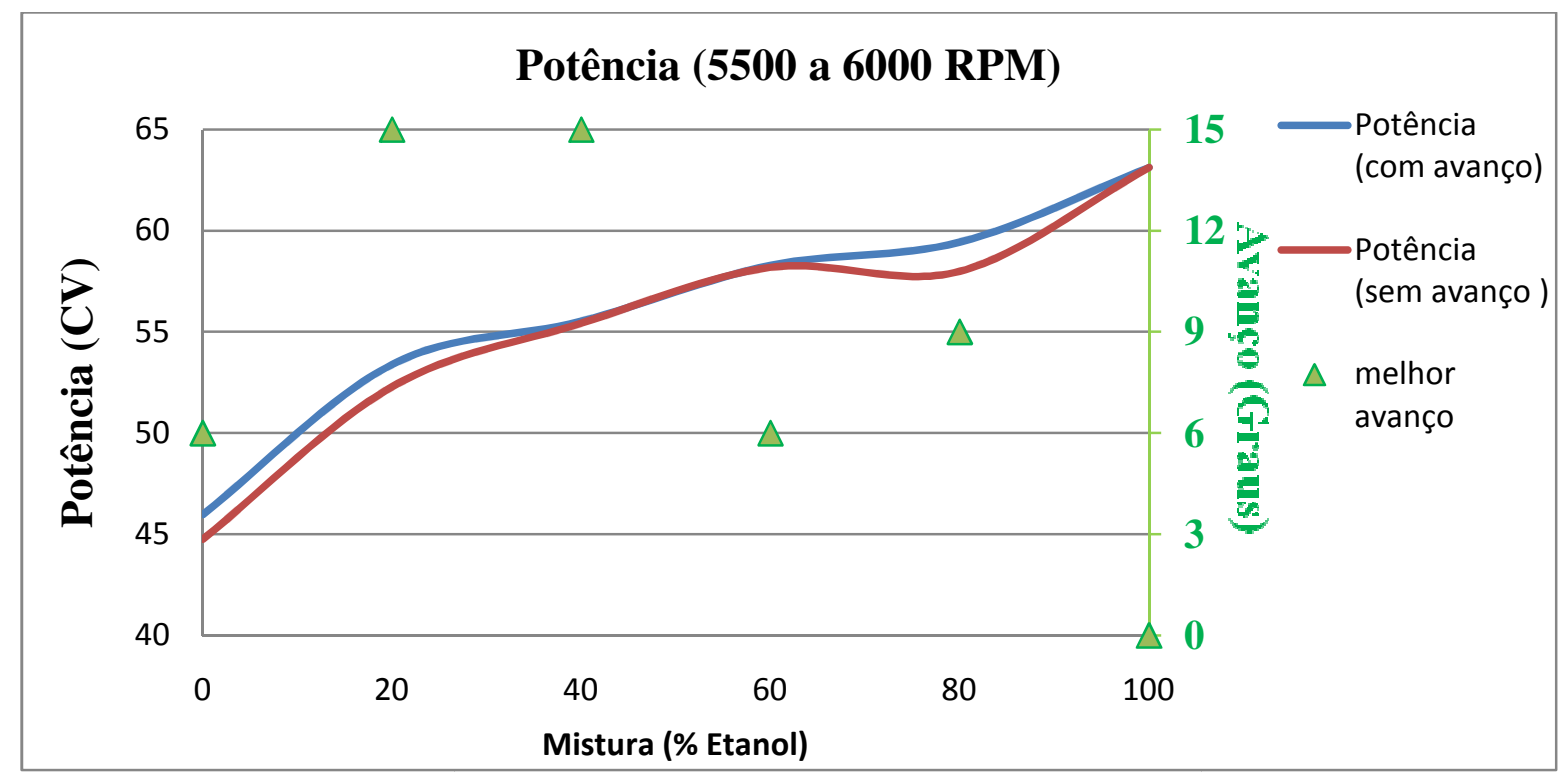

Gráfico 17 - Potência, avanço e mistura em \%, para uma rotação média de 5500 a 6000 rpm[33].

Tabela 26 - Potência, avanço e mistura em \%, para uma rotação média de 6000 a 6500 rpm [33].

\begin{tabular}{ccccc}
\hline $\begin{array}{c}\text { Mistura } \\
(\% \text { de etanol })\end{array}$ & $\begin{array}{c}\text { Mistura } \\
(\% \text { de GNV) }\end{array}$ & $\begin{array}{c}\text { Potência com } \\
\text { Avanço }\end{array}$ & $\begin{array}{c}\text { Melhor } \\
\text { avanço }\end{array}$ & $\begin{array}{c}\text { Potência } \\
\text { (sem avanço) }\end{array}$ \\
\hline $\mathbf{0}$ & 100 & 45,40 & 6 & 43,38 \\
$\mathbf{2 0}$ & 80 & 52,58 & 0 & 52,58 \\
$\mathbf{4 0}$ & 60 & 54,97 & 0 & 54,97 \\
$\mathbf{6 0}$ & 40 & 56,32 & 6 & 56,14 \\
$\mathbf{8 0}$ & 20 & 56,20 & 9 & 54,11 \\
$\mathbf{1 0 0}$ & 0 & 61,76 & 0 & 61,76 \\
\hline
\end{tabular}

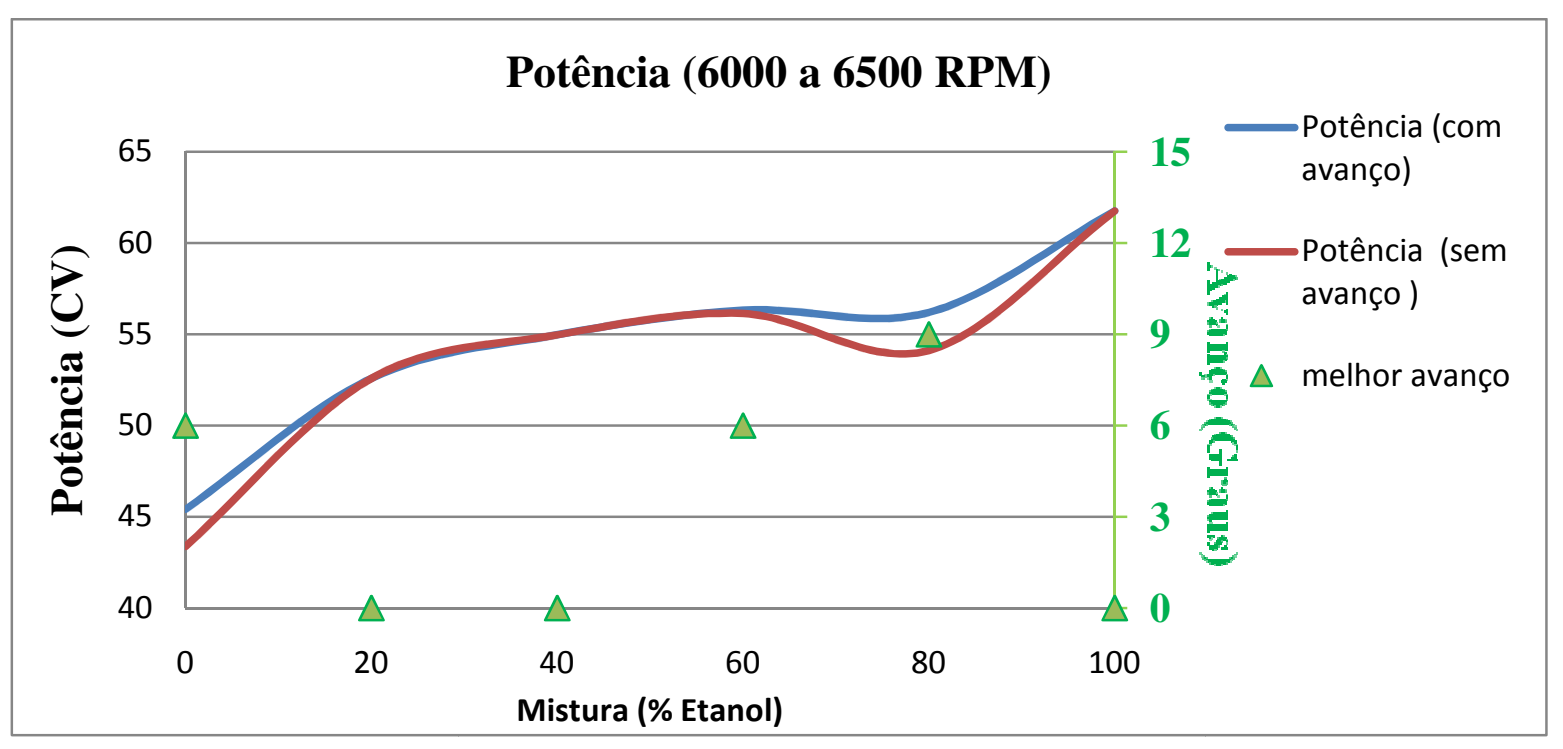

Gráfico 18 - Potência, avanço e mistura em \%, para uma rotação média de 6000 a 6500 rpm [33]. 
Devido ao variador de avanço se mostrar eficiente apenas em algumas situações específicas de mistura de 0 a $20 \%$ de etanol, a uma faixa de rotação de até $3000 \mathrm{rpm}$, optou-se por fazer a calibração sem o uso do variador de avanço. No Gráfico 19, é apresentada a curva de potência em diferentes proproções de etanol sem correção de avanço, onde a porcentagem indica a parcela de etanol, sendo seu complemento feito com GNV. Observa-se que o uso de $40 \%$ de etanol produz ganho de potência superior ao uso de $100 \%$ de etanol na faixa de rotação até $3000 \mathrm{rpm}$.

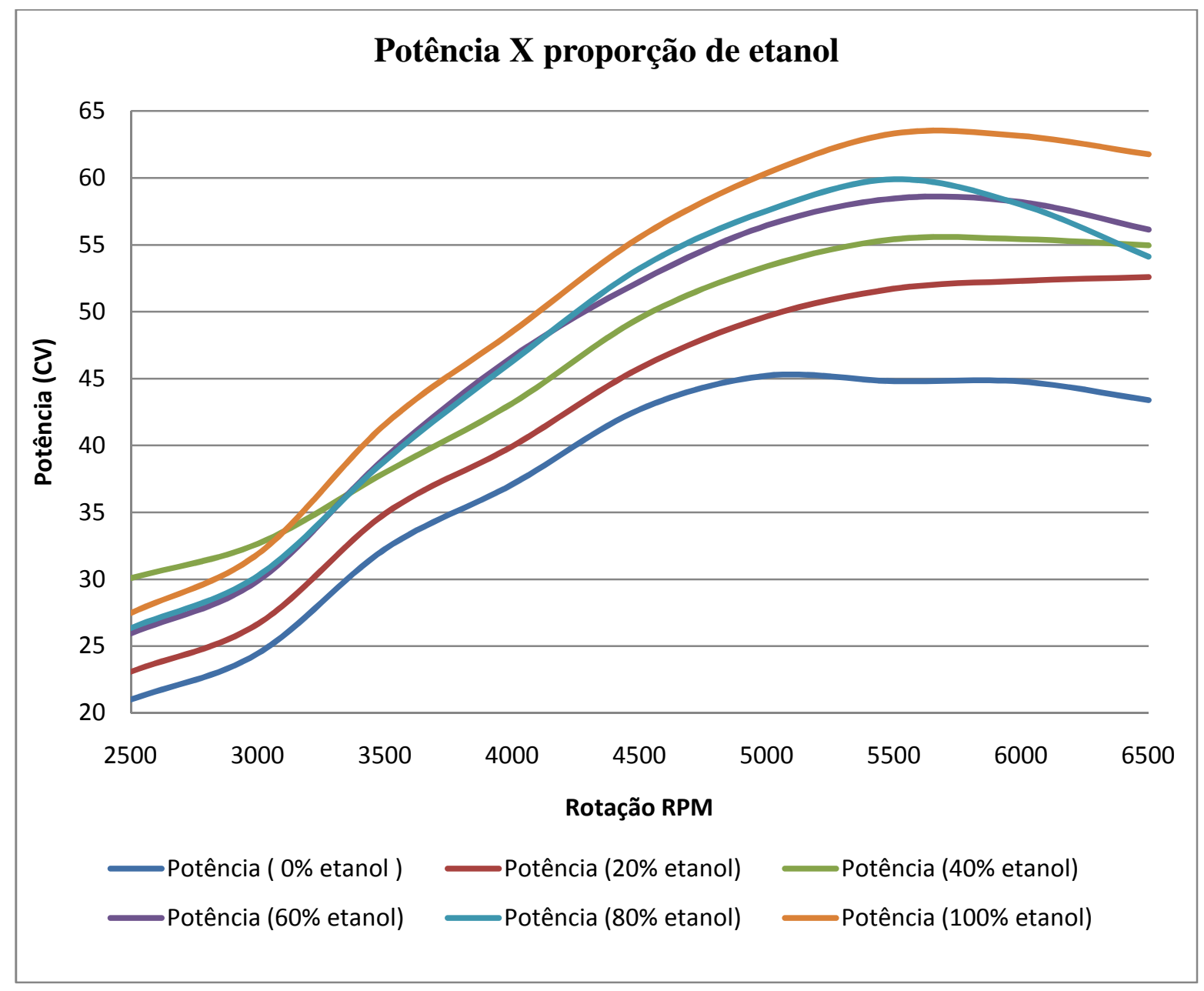

Gráfico 19 - Curva de potência em diferentes proporções de etanol [33]. 


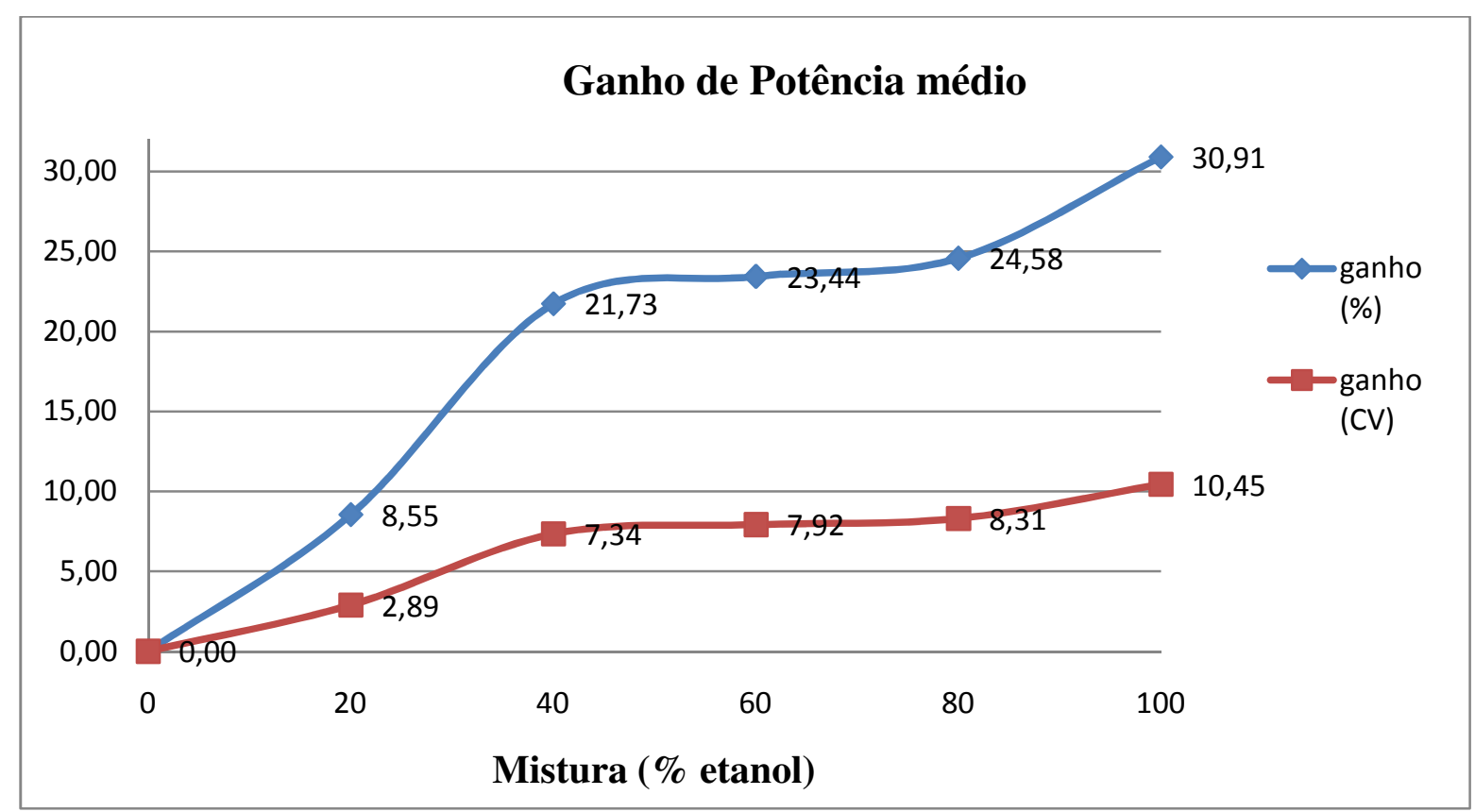

Gráfico 20 - Ganho de potência médio [33].

Analisando a potência média em cada faixa de rotação em diferentes proproções de etanol, de acordo com o Gráfico 20, observa-se um ganho de potência significativo nas proproções de etanol de 20 e $40 \%$ produzindo ganhos de $8,55 \%$ e $21,73 \%$, respectivamente.

No Gráfico 21, é apresentada a potência máxima em diferentes proporções de etanol e GNV. A curva de potência é mais acentuada para as proporções iniciais de 20 e 40\%, com potência de $6,92 \mathrm{Cv}$ quando utilizado $20 \%$ de etanol, e $11 \mathrm{Cv}$ quando utilizado $40 \%$ de etanol.

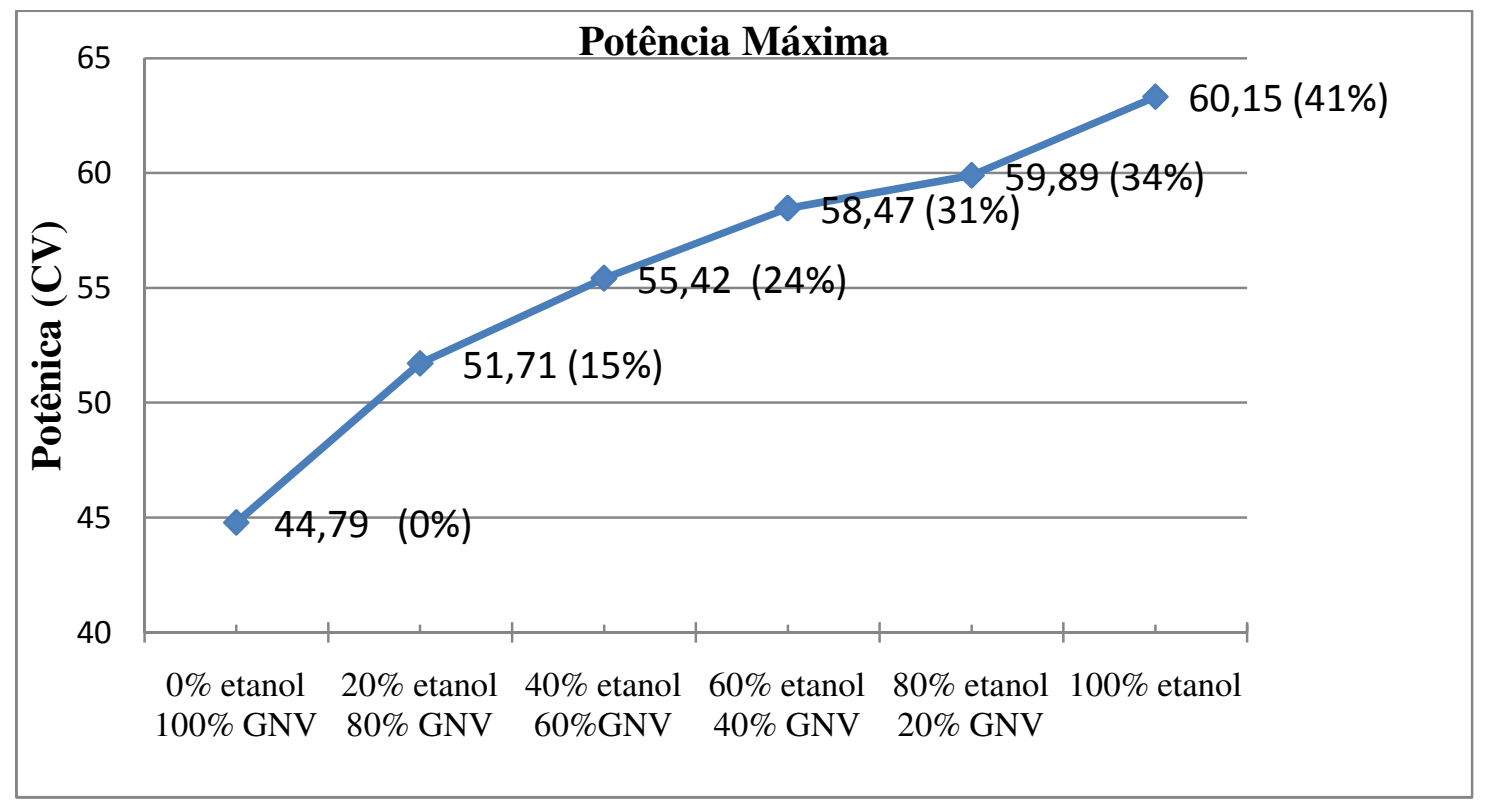

Gráfico 21 - Potência Máxima X proporção de Etanol[33]. 
No Gráfico 22, são apresentadas as curvas de potência em diferentes acelerador, onde se observa que o ganho de potência ocorre quando $\mathrm{p}$ acelerador acima de 50\%, representando a calibração final do VW gol.

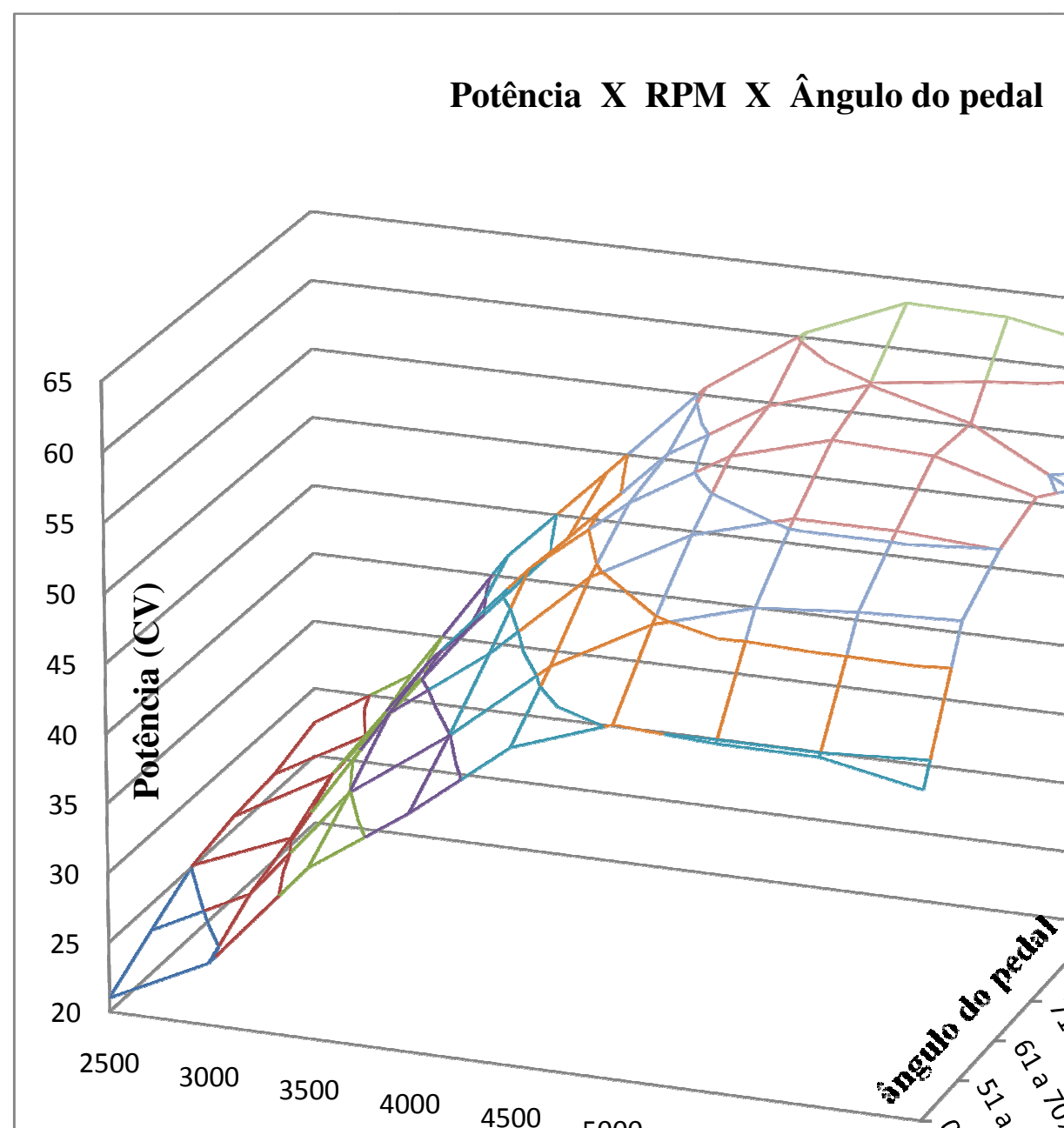

Gráfico 22 - Potência X Rotação X Ângulo do pedal [33] 


\subsection{EMISSÃO DE POLUENTES}

Não Gráfico 23, são apresentadas as média das medições de emissão de $\mathrm{CO}$ e $\mathrm{HC}$, para o sistema aspirado e o protótipo feira em marcha lenta a $900 \mathrm{rpm}$ e a $2500 \mathrm{rpm}$. Com o uso do GNV simultâneo com o etanol a partir de $20 \%$ tem-se redução nas emissões quando comparado com o uso somente do GNV. $\mathrm{O} \mathrm{CO}_{2}$ que é o principal gás responsável pelo efeito estufa, não é tratado diretamente como poluente, pois é a parte principal da conversão de energia no processo de combustão e sua redução só é possível com o aumento da eficiência volumétrica. Um aumento significativo da eficiência volumétrica foi alcançado com o protótipo desenvolvido quando comparado com o sistema convencional aspirado, proporcionando um aumento de $25 \%$.

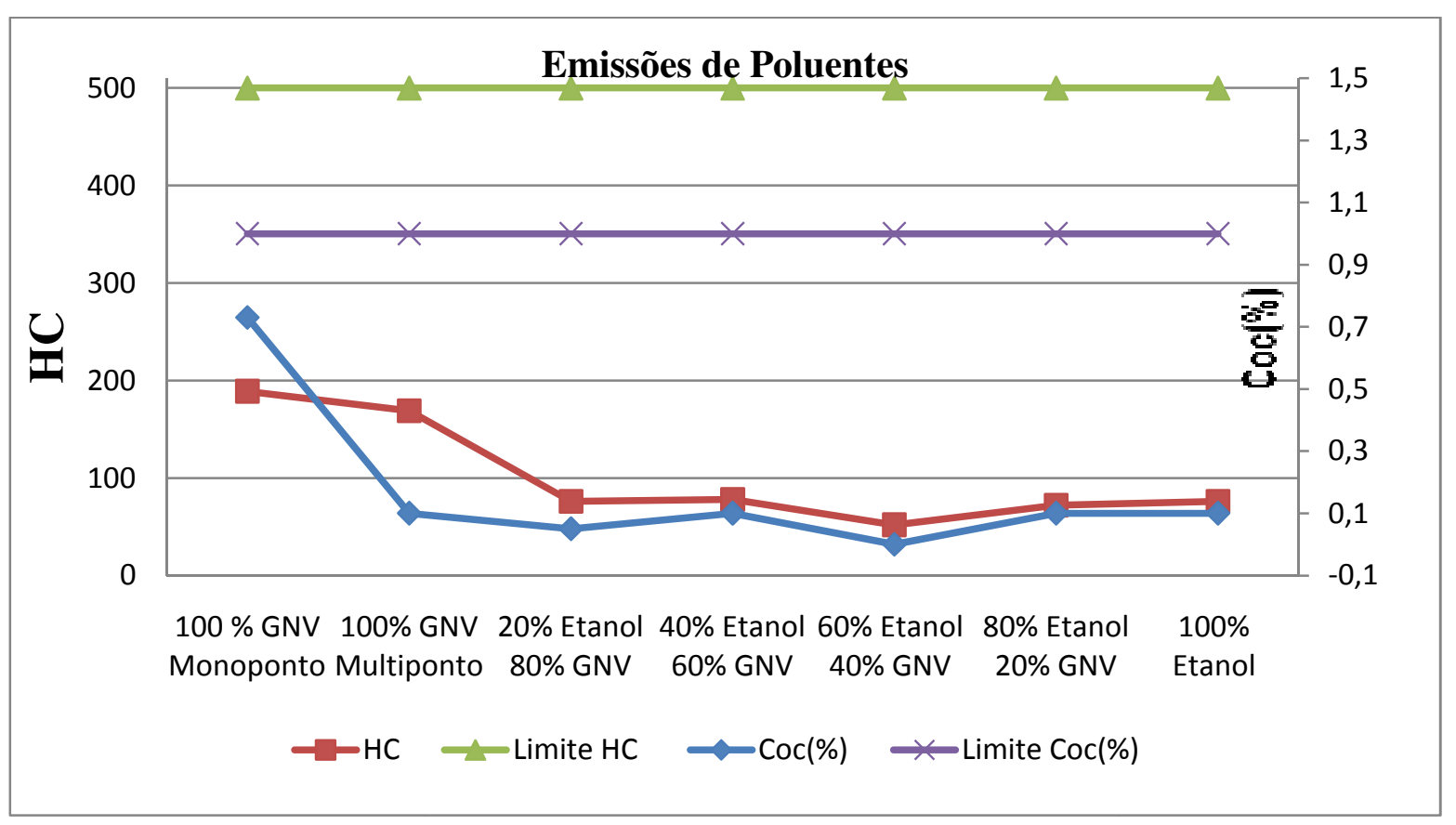

Gráfico 23 - Emissões de Poluentes HC e COc(média entre 900 e 2500 rpm) [33].

\subsection{ENSAIOS RODOVIÁRIOS}

Neste capítulo, são descritos os ensaios rodoviários realizados em estrada com velocidade média de $90 \mathrm{Km} / \mathrm{h}$, utilizando os dois veículos de teste. 


\subsubsection{Ensaios rodoviários com o Daewoo Lanos}

Nestes ensaios, foram medidos o consumo do veículo utilizando Etanol, Gasolina e GNV e a mistura de GNV com $10 \%$ de etanol. O valor de $10 \%$ de etanol foi escolhido por ser o menor valor onde o efeito de histerese não provocou falhas no motor.

Na Tabela 27 e no Gráfico 24, é apresentado o consumo em quilômetros, observando que a comparação entre os combustíveis líquidos e o GNV são feitas entre o litro do combustível líquido e o $\mathrm{m}^{3}$ do GNV, pois essa é a unidade de medida para cálculo do preço vendido nos postos. Fica evidente a vantagem econômica com o uso do GNV, pois possui o menor consumo específico e o menor valor por $\mathrm{m}^{3}$, comparado com o litro do etanol ou gasolina.

Tabela 27 - Consumo dos combustíveis no Daewoo Lanos [33].

\begin{tabular}{|c|c|c|}
\hline Combustível (sistema de injeção) & Consumo Etanol & Consumo GNV \\
\hline $100 \%$ Etanol & $10,95 \mathrm{~km} / 1$ & - \\
\hline Gasolina E22 (sistema Multiponto) & $13,14 \mathrm{~km} / 1$ & - \\
\hline Combustível (sistema de injeção) & Consumo Etanol & Consumo GNV \\
\hline $100 \%$ GNV (sistema aspirado monoponto) & - & $15,04 \mathrm{~m}^{3} / \mathrm{Km}$ \\
\hline 90\% GNV 10\% Etanol ( sistema Multiponto ) & $117,14 \mathrm{Km} / 1$ & $19,85 \mathrm{~m}^{3} / \mathrm{Km}$ \\
\hline 100\% GNV ( Sistema Multiponto ) & - & $19,17 \mathrm{~m}^{3} / \mathrm{Km}$ \\
\hline
\end{tabular}

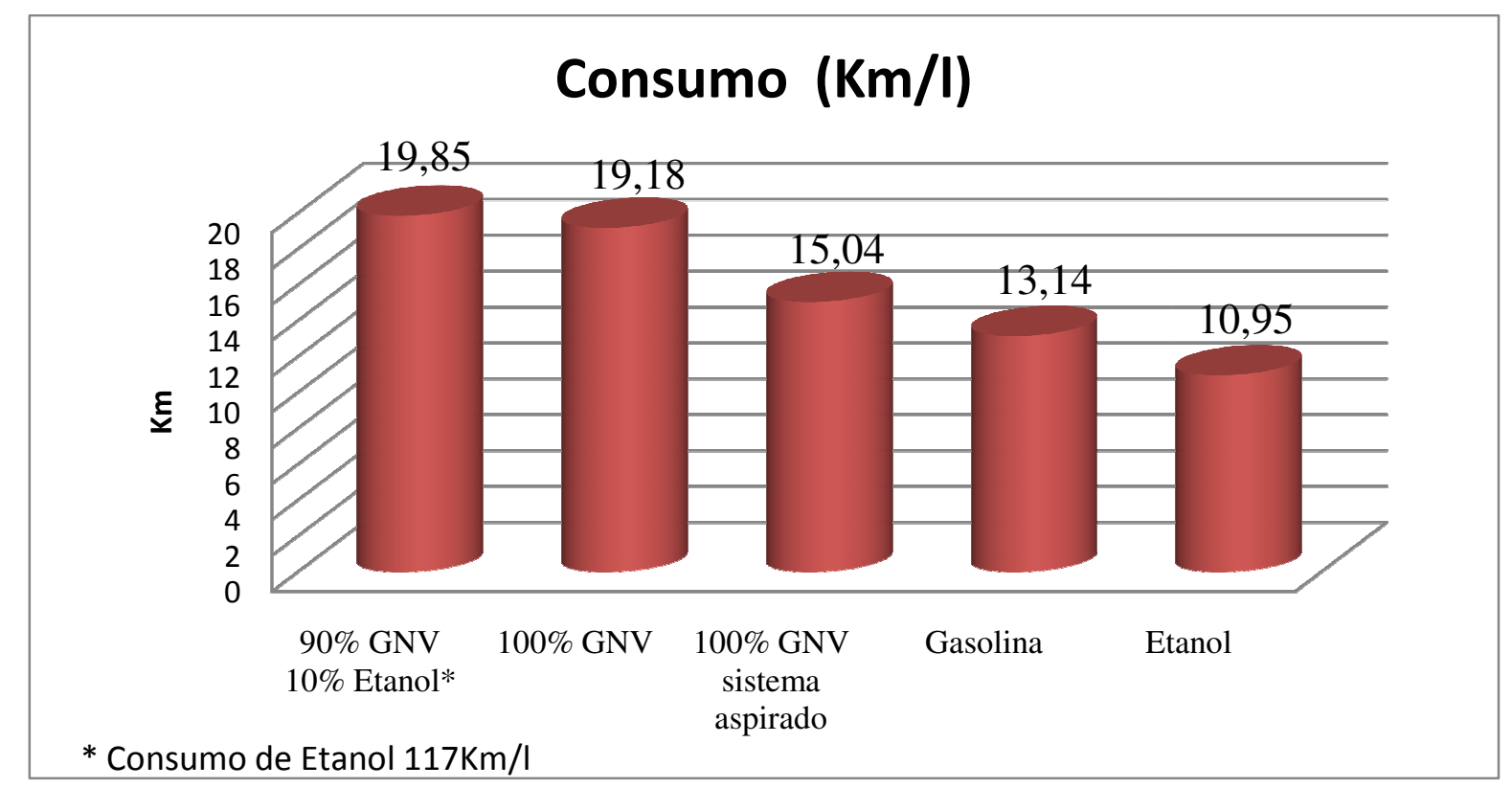

Gráfico 24 - Consumo do Daewoo Lanos[33]. 
Para uma análise financeira, foram utilizados os preços médios dos combustíveis na cidade de São Paulo (conforme item 2.8). No Gráfico 25 baseado na Tabela 28, tem-se o custo mensal com o uso de cada combustível, tendo como base a quilometragem média mensal no Brasil de $1106 \mathrm{~km}$ [47]. No Gráfico 25, observa-se a linha verde referente ao GNV com o sistema aspirado, a linha vermelha referente etanol e a linha azul referente ao sistema de GNV multiponto. Os preços entre o etanol e o sistema de GNV aspirado ficaram muito próximos nos meses de janeiro a junho, tornando o GNV vantajoso somente após junho. Entretanto, quando a comparação é feita utilizando o protótipo desenvolvido, o GNV é vantajoso durante todo o período analisado.

Tabela 28 - Consumo mensal em reais dos combustíveis na cidade de São Paulo[33].

\begin{tabular}{cccccc}
\hline Meses & $\begin{array}{c}100 \% \\
\text { Gasolina E22 }\end{array}$ & $\begin{array}{c}100 \% \\
\text { etanol }\end{array}$ & $\begin{array}{c}\text { GNV } \\
\text { aspirado }\end{array}$ & $\begin{array}{c}90 \% \text { GNV e } \\
10 \% \text { etanol }\end{array}$ & $\begin{array}{c}100 \% \text { GNV } \\
\text { (Multiponto) }\end{array}$ \\
\hline Janeiro & 201,25 & 132,51 & 127,15 & 108,71 & 99,75 \\
Fevereiro & 201,67 & 134,03 & 127,96 & 109,46 & 100,38 \\
Março & 201,25 & 134,63 & 127,15 & 108,91 & 99,75 \\
Abril & 199,23 & 129,08 & 126,64 & 108,00 & 99,34 \\
Maio & 199,06 & 126,76 & 126,71 & 107,84 & 99,40 \\
Junho & 197,46 & 119,18 & 117,44 & 100,11 & 92,13 \\
Julho & 196,96 & 121,71 & 112,74 & 96,78 & 88,44 \\
Agosto & 197,63 & 124,23 & 112,22 & 96,62 & 88,03 \\
Setembro & 198,89 & 132,01 & 110,02 & 95,68 & 86,30 \\
Outubro & 202,01 & 151,70 & 112,52 & 99,42 & 88,27 \\
Novembro & 204,20 & 156,75 & 110,46 & 98,33 & 86,65 \\
Dezembro & 205,21 & 162,00 & 110,24 & 98,65 & 86,48 \\
\hline Custo Anual & 2404,82 & 1624,59 & 1421,23 & 1228,49 & 1114,92 \\
\hline
\end{tabular}




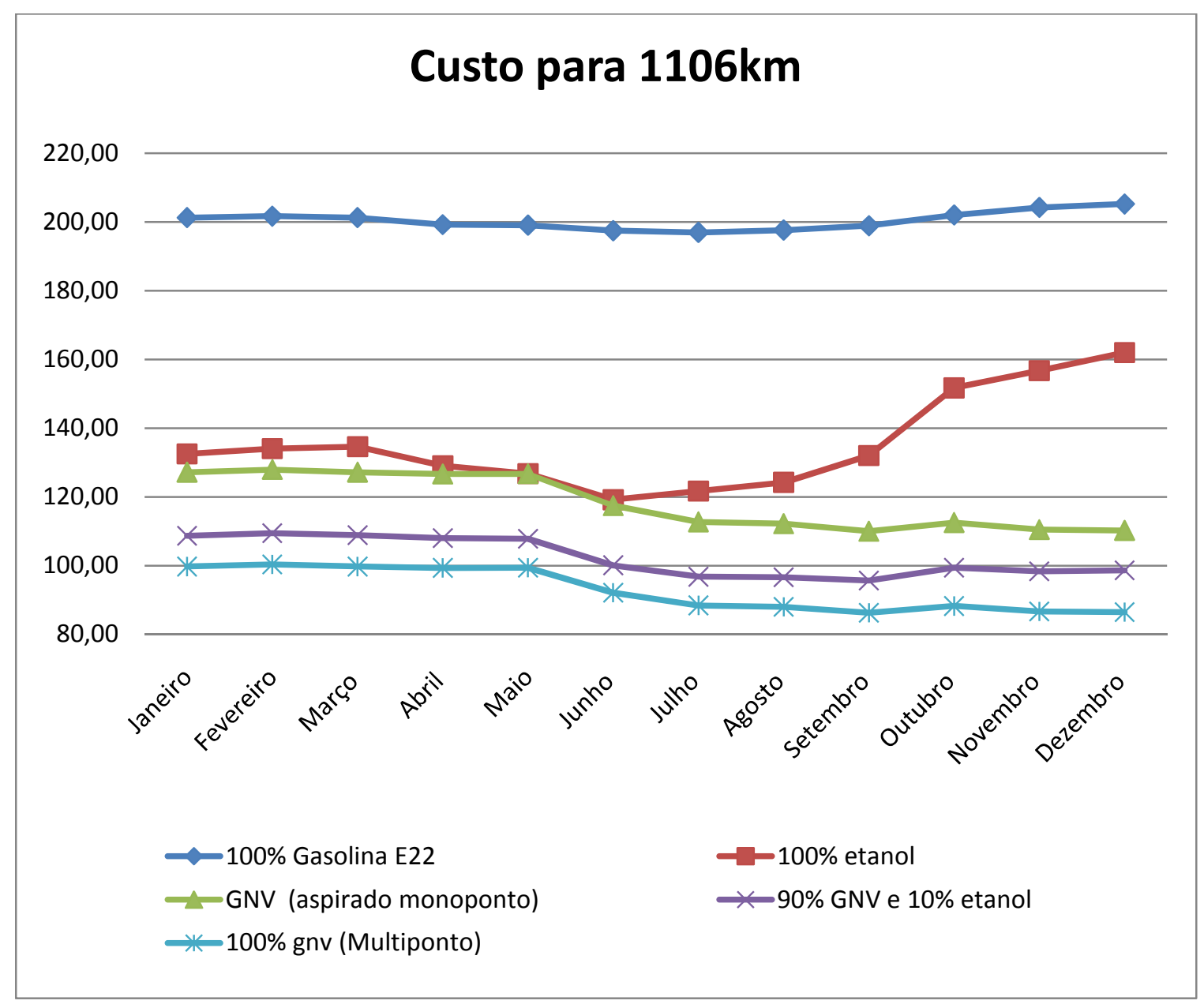

Gráfico 25- Consumo dos combustíveis na cidade de São Paulo[33].

\subsubsection{Ensaios rodoviários com o VW Gol}

Nos ensaios rodoviários foram medidos o consumo utilizando Etanol, gasolina e GNV, e a mistura de GNV e etanol, nas proporções de 20, 40 60, 80\% de etanol. Na Gráfico 26 obtido apartida da tabela 29, são apresentados o consumo dos combustíveis analisados, o consumo individual de cada combustível e o consumo quando utilizado os dois combustíveis simultaneamente. mesmo sem a injeção simultânea, o sistema Multiponto teve rendimento maior que o sistema aspirado monoponto. 
Tabela 29 - Consumo dos combustíveis no VW Gol[33].

\begin{tabular}{lcc}
\hline Combustível (sistema de injeção) & Consumo $\mathrm{km} / \mathrm{m}^{3}$ & Consumo Km/L \\
\hline $100 \%$ GNV (sistema aspirado monoponto) & 21,00 & \\
$100 \%$ GNV (sistema injetado Multiponto) & 26,40 & \\
$20 \%$ Etanol + $80 \%$ GNV & 33,00 & 41,25 \\
$40 \%$ Etanol + 60\% GNV & 44,50 & 25,99 \\
$60 \%$ Etanol + 40\% GNV & 58,77 & 19,71 \\
$80 \%$ Etanol + 20\% GNV & 83,33 & 16,44 \\
$100 \%$ Etanol & & 12,65 \\
$100 \%$ Gasolina & & 16,23 \\
\hline
\end{tabular}

As variações de proporções de etanol e GNV são para referência, pois são utilizadas apenas quando a maior potência é exigida.

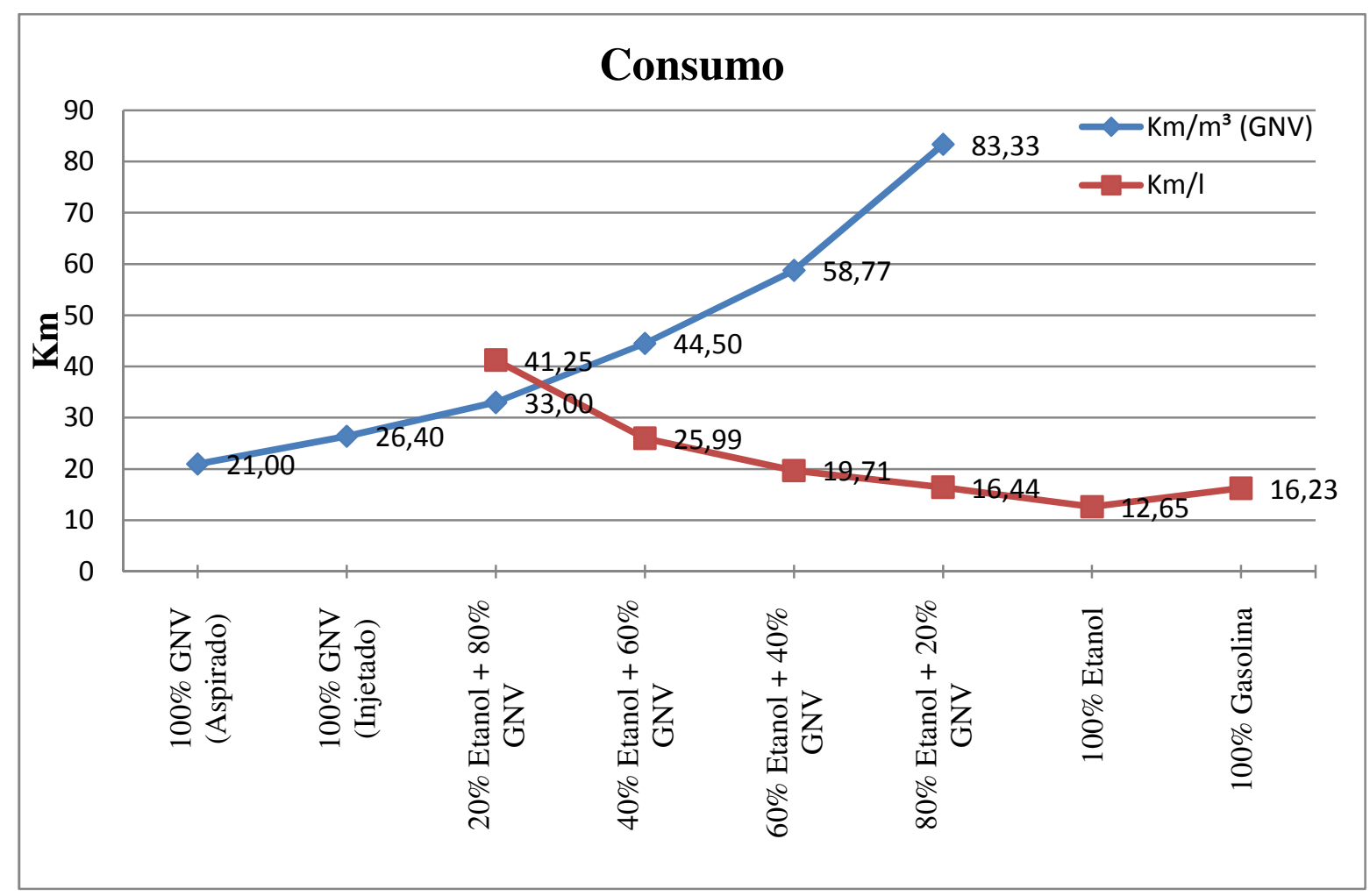

Gráfico 26- Consumo do VW Gol [33]. 


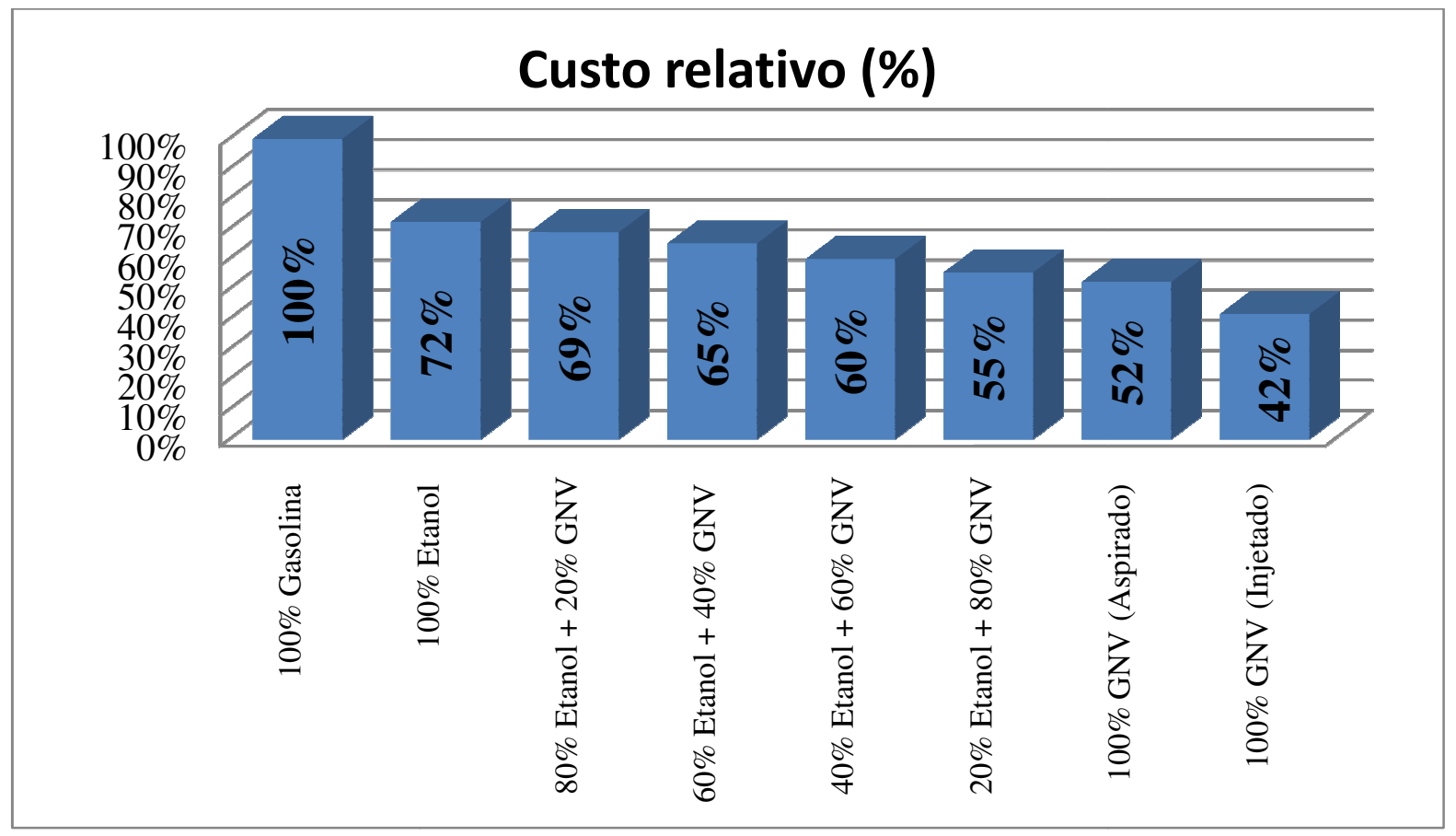

Gráfico 27 - Custo relativo com os combustíveis [33].

No Gráfico 27, é apresentado o custo relativo. Observa-se a vantagem com o uso do GNV em relação ao etanol e principalmente em relação à gasolina.

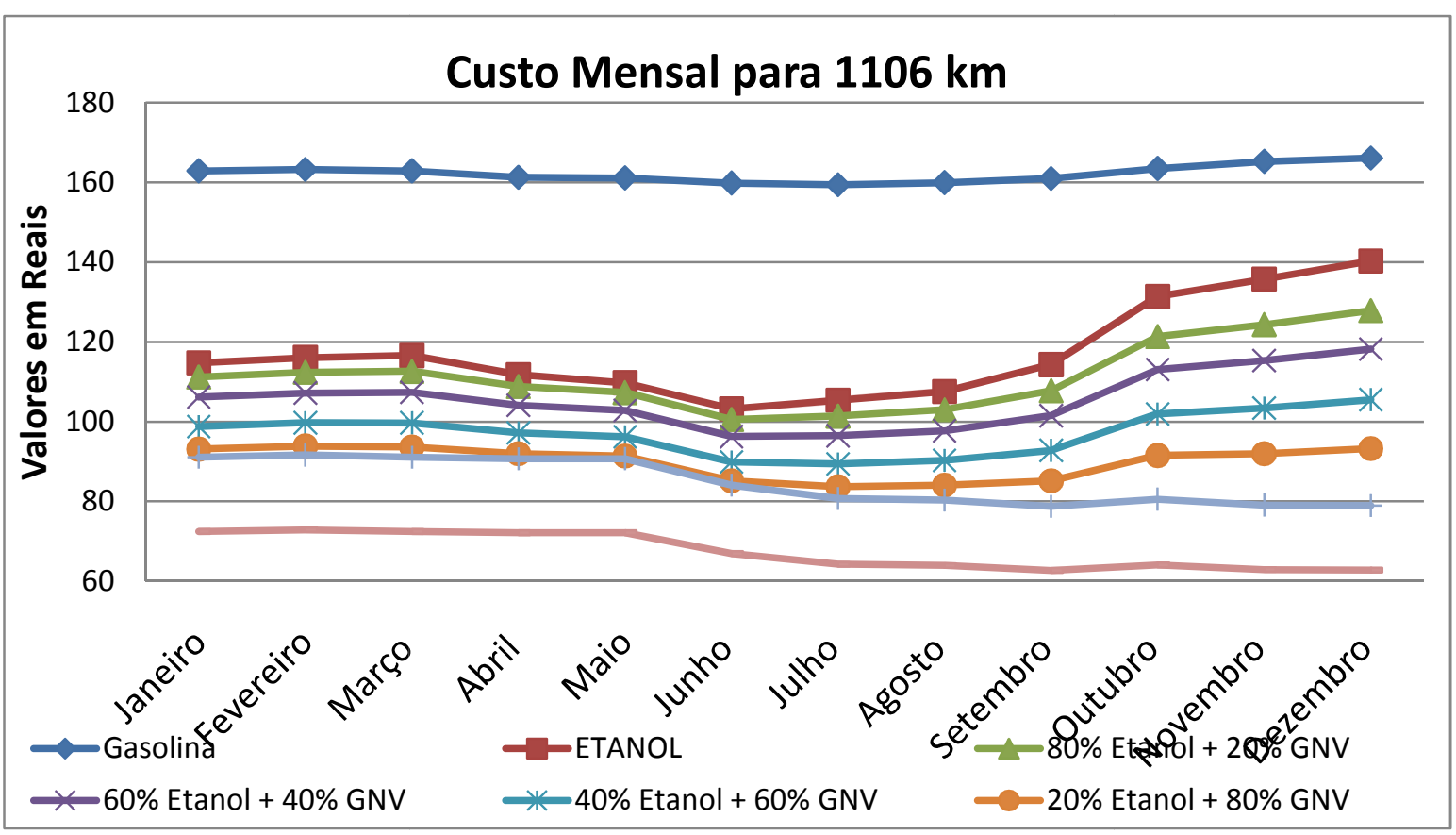

Gráfico 28 - Custo mensal estimado com combustível [33]. 


\subsection{VIABILIDADE ECONÔMICA}

Para o estudo de viabilidade econômica, foi feita uma comparação entre o sistema de conversão aspirado e o protótipo desenvolvido. O custo dos equipamentos e instalação foram consultados em convertedoras homologadas pelo Inmetro, apresentados no Anexo 01. O sistema convencional aspirado teve seu custo médio de R $\$ 1642,50$. O sistema com injeção positiva teve seu custo $133 \%$ maior, $\mathrm{R} \$ 3834,00$. O mesmo custo foi estabelecido para o protótipo desenvolvido por utilizar o mesmo sistema mecânico, que representa a maior parte do custo final do produto. Na Tabela 30, é apresentado um comparativo entre os sistemas de conversão GNV aspirado e o protótipo desenvolvido.

Tabela 30 - Comparativo financeiro entre o sistema de conversão aspirado e o protótipo desenvolvido[33].

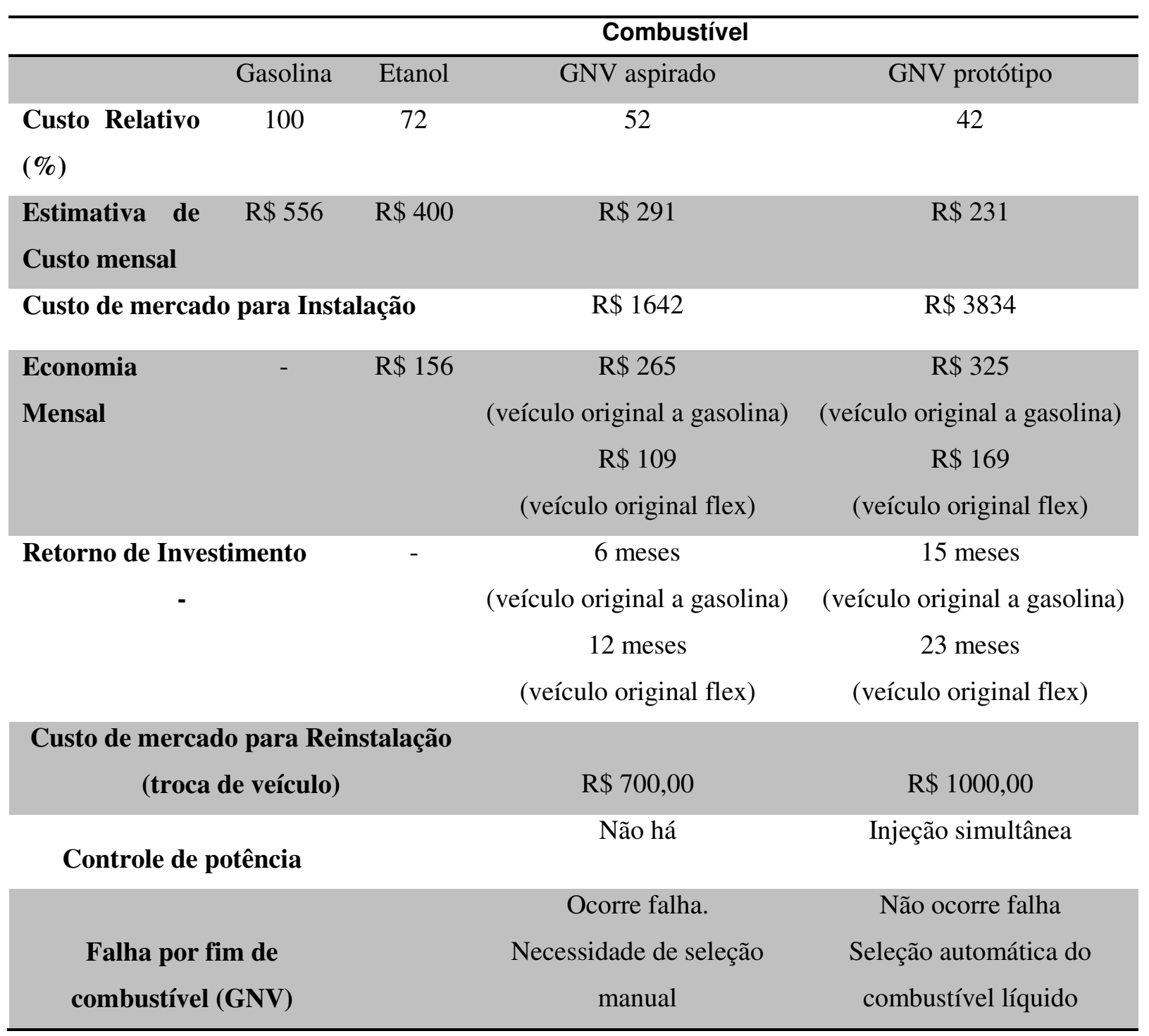


Para um consumidor com gasto de $\mathrm{R} \$ 100,00$ por semana, que utiliza um veículo original flex, o retorno de investimento estimado é de 23 meses. Embora o retorno de investimento possa ser considerado longo, esse tempo pode ser compensado pois o sistema pode ser reinstalado em outro veículo a um custo de $\mathrm{R} \$ 1000,00$, já inclusos a tubulação, que não é reaproveitada na reinstalação, e a vistoria obrigatória do Inmetro.

O GNV possui baixa autonomia, tornando comum seu uso até o fim do cilindro. No sistema aspirado o veículo falha quando a pressão no cilindro não é suficiente, comprometendo a segurança, pois o motorista precisa manualmente selecionar o combustível líquido. No protótipo desenvolvido e nos sistemas de injeção positiva comerciais, a seleção para o combustível líquido é automática quando a pressão no cilindro é inferior à pressão de trabalho.

Em alguns Estados, a legislação concede descontos no IPVA (imposto sobre veículos automotores) para veículos movidos a GNV. No Rio de Janeiro, o IPVA cobrado é de $1 \%$ sobre o valor do veículo para todos os veículos de passeio movidos a GNV. Para um veículo de passeio a gasolina ou flex, sem o GNV, o valor cobrado é de 4\% sobre o valor do veículo [48]. Considerando apenas o desconto do IPVA, um veículo no valor de $\mathrm{R} \$ 60000,00$ tem seu retorno de investimento em 24 meses, e aplicando as mesmas condições da Tabela 30 o retorno de investimento é de apenas um ano.

Em São Paulo, a redução de 4\% para 3\% sobre o valor do veículo é dada aos veículos a etanol ou gás natural, não concendendo nenhum desconto adicional na conversão de veículo bicombustível para tricombustível[49] . 


\section{CONCLUSÕES}

O estudo realizado apresenta o uso simultâneo de GNV e do combustível líquido, principalmente o etanol, como estratégia para compensar a perda de potência quando utilizado o GNV.

O veículo Volkswagen Gol, com seu sistema original utilizando somente etanol, possui potência máxima de 63,3 cavalos e consumo de 12,6 quilômetros por litro de etanol. Com o sistema convencional de gás natural aspirado, o consumo foi de $21 \mathrm{~km} / \mathrm{m}^{3}$ e a potência não ultrapassou 44,79 Cv. Com o protótipo desenvolvido, a eficiência volumétrica aumenta $25 \%$ com consumo de $26,4 \mathrm{Km} / \mathrm{m}^{3}$. O gerenciamento de potência permite atingir potências intermediárias acima de $44,70 \mathrm{Cv}$ até a potência máxima de $63,1 \mathrm{Cv}$, quando utilizado somente o etanol.

A potência máxima encontrada foi com o uso somente de etanol. Entretanto, foi observado que a curva de potência máxima em diferentes proporções de etanol é mais acentuada nas proporções iniciais de 20 a $40 \%$ de etanol, tornando-se menos acentuada nas proporções de 60 a $80 \%$, sendo acentuada novamente quando ocorre a mudança de 80 para $100 \%$ de etanol.

O variador de avanço, comercialmente utilizado na conversão de veículos para GNV, não se mostrou eficiente no VW Gol, mas não se pode concluir que seu uso seja desnecessário em todos os veículos. Uma hipótese para sua baixa eficiência é o fato do veículo possuir o sensor de detonação que auxilia na adaptação ao ponto de ignição, adaptando automaticamente a curva de avanço para uso do GNV.

O uso das válvulas injetoras originais do veículo não se mostraram compatíveis para injeção de GNV, não sendo possível seu uso como estratégia para redução de custos.

Através das curvas de potências obtidas com o protótipo desenvolvido, pode-se concluir que o gerenciamento de potência através do uso simultâneo de GNV e etanol, que utiliza o ângulo do pedal do acelerador para definir a prioridade de potência e economia, mostrou-se como eficiente estratégia para atender uma das principais expectativas do consumidor que deseja um veículo potente sempre que necessário e econômico sempre que conveniente.

O sistema alia a flexibilidade no abastecimento com a flexibilidade da potência, através do gerenciamento de injeção simultânea do combustível, sem necessidade de intervenção do motorista. 


\section{TRABALHOS FUTUROS}

\subsection{DESENVOLVIMENTO DE UM PROTÓTIPO DE UM SISTEMA TRICOMBUSTÍVEL TURBO ALIMENTADO}

Como proposta para trabalho futuro, seria interessante dar continuidade a este trabalho incluindo o gerenciamento de um turbocompressor. Um sistema semelhante ao desenvolvido com a opção de gerenciamento da pressão de turbo, proporcionando um aumento da potência, devido ao aumento da massa de ar de entrada, podendo aumentar a pressão do turbo, sempre que utilizado o GNV, pois sua maior octanagem permite o uso de maiores pressões. O gerenciamento de potência pode atuar na variação da mistura do GNV com o combustível líquido, e também alterar a pressão de turbo em função do ângulo do pedal do acelerador. Ensaios dinamométricos e rodoviários seriam necessários para mensurar os benefícios em relação ao ganho de potência e rendimento do combustível.

\subsection{ESTUDO DO DESGASTE DE MOTORES CONVERTIDOS A GNV}

A conversão de veículos para GNV é feita em veículos com motores projetados para uso do combustível líquido. Uma das desvantagens do GNV é não auxiliar na lubrificação e arrefecimento da válvula de admissão. Todavia, sua vantagem é baixa contaminação do óleo lubrificante. Um estudo sobre o desgaste do motor que utiliza GNV incluindo o estudo de emissões ao longo de sua vida útil, seria uma importante informação para tomada de decisão no uso do GNV. 


\subsection{PROTÓTIPO DE UM SISTEMA DE INJEÇÃO DE ETANOL PRE- VAPORIZADO}

No item 2.5, foi apresentado um projeto de etanol pré-vaporizado. Embora tivesse apresentado resultados positivos, o uso desse sistema não foi comercialmente utilizado. $\mathrm{O}$ etanol, por ser um combustível de composto único, pode ser totalmente vaporizado antes de entrar na câmara de combustão. O sistema de controle do combustível totalmente mecânico foi apresentado como estratégia para aumento do rendimento do combustível. O etanol pode ser vaporizado utilizando o calor do escapamento, ou através de ultra-som.

O desenvolvimento de um novo sistema de vaporização do etanol, com controle eletrônico da vaporização e injeção do combustível, pode ser avaliado com estratégia para redução do consumo de etanol, comparado com os sistemas de injeção atual.

\subsection{ESTUDO SOBRE O COMPORTAMENTO DO VARIADOR DE AVANÇO EM MOTORES CONVERTIDOS A GNV}

Um estudo mais detalhado sobre o uso do variador de avanço em veículo convertidos para GNV seria importante para avaliar sua eficiência e necessidade de seu uso, uma vez que é muito utilizado comercialmente.

\subsection{VÁLVULA INJETORA E REDUTOR DE PRESSÃO DE BAIXO CUSTO PARA SISTEMA DE CONVERSÃO GNV}

Os principais componentes do sistema de injeção de GNV com pressão positiva são as válvulas injetoras e o redutor de pressão. Com a redução nos custos desses dispositivos, o custo do sistema de conversão com pressão positiva se aproximaria do sistema aspirado, tonando possível uma modernização da frota de veículos movidos a GNV.

Essa redução nos custos só é possível com a nacionalização e o desenvolvimento de dispositivos de baixo custo. 


\subsection{SISTEMA DE GNV ASPIRADO COM INJEÇÃO SIMULTÂNEA DE ETANOL OU GASOLINA}

Embora o sistema aspirado não permita ajuste da mistura, o GNV poderia ser manualmente ajustado para mistura pobre em todas as faixas de rotação, e o combustível líquido seria injetado como um combustível complementar para controlar a estequiometria da mistura. Os custos nesse sistema seriam semelhantes ao custo do sistema aspirado. Um possível aumento no rendimento e potência devido ao controle da estequiometria da mistura deve ser avaliado. 


\section{REFERÊNCIAS BIBLIOGRÁFICAS}

1. ANFAVEA. Autoveículos - Produção, vendas internas e exportações. Anuário da Indústria Automobilística Brasileira, p. 72, 2009.

2. JORNAL O ESTADO DE SÃO PAULO. Brasil já tem carro flex fuel, que funciona com álcool ou gasolina, São Paulo, 30/03/2003.

3. LEÃO, R. M. Álcool Energia Verde. [S.1.]: Iqual Instituto de Qualificação Editora Ltda, 2002.

4. AGÊNCIA NACIONAL DO PETRÔLEO, GÁS NATURAL E BIOCOMBUSTÍVEIS (ANP). Regulamento Técnico $\mathbf{n}^{\circ}$ 05/2001... Diário Oficial da União, 2001.

5. JUNIOR, L. M. CONVERSÃO DE MOTORES DIESEL PARA GÁS NATURAL. Proceedings of the 11th Brazilian Congress of Thermal Sciences and Engineering -ENCIT 2006, 2006.

6. DICIONÁRIO AURÉLIO. Dicionário de lingua portuguesa. 4. ed. [S.1.]: Editora Nova Fronteira, 2001.

7. PETROBRAS. Sobre Energias Renováveis. Disponivel em: $<$ http://www2.petrobras.com.br/espacoconhecer/EnergiasRenovaveis/Biomassa.asp>. Acesso em: 28 abr. 2010. Acesso em 20 set 2008.

8. AGÊNCIA NACIONAL DO PETRÓLEO, GÁS NATURAL E BIOCOMBUSTÍVEIS (ANP). Diário Oficial da União. Resolução ANP n 09, 02/04/2009.

9. REVISTA TN PETRÓLEO. Neogás desenvolve tecnologia de transporte GNC., out/2004.

10 AGÊNCIA NACIONA DO PETRÓLEO GÁS NATURAL E BIOCOMBUSTÍVEIS (ANP). Diário Oficial da União. Resolução ANP 16, 17/06/2008.

11 AGÊNCIA NACIONAL DO PETRÓLEO, GÁS NATURAL E BIOCOMBUSTÍVEIS (ANP). Diário Oficial da União. Resolução ANP 32, 06/03/2001.

12 BURGER, P.R.B. BAETA, J.G.C. VALLE, R.M. Desempenho de um motor multicombustível operando simultaneamente com GNV e álcool etilico em diferentes proproções. Simpósio internacional de engenharia automotiva - SIMEA, 2009.

13 KANTER, JAMES. Herald Tribune. Suécia Transforma esgoto em combustível para carro, Herald Tribune, 2008. 
14 PONTUAL, F. Com flexibilidade, a oferta aumenta. Revista Brasil Energia, 2008.

15 TABUENCA, T.B. Ciência e Tecnologia. Rio de Janeiro: Klick, 1996. 193 p.

16 WILDNER, F. D. Estudo experimental da variação de velocidade de combustão para diferentes combustíveis, relações de mistrua e relações de compressão em um motor ASTM CFR, Porto Alegre, 2006.

17 HEYWOOD, JOJH B. Internal Combustion Engine Fundamentals. New York: McGraw-Hill, 1988.

18 LANDMANN, M.C; RIBEIRO. H; DEÁK C. Transportes. Uma proposta metodológica para estimar o custo da poluição do ar nas análises de viabilidade, XV, 2007.

19 CETESB. Relatório de emissão veicular, 05 abr. 2009. Disponivel em: <http://www.cetesb.sp.gov.br/Ar/emissoes/introducao.asp>. Acesso em: 20 jul. 2010.

20 CETESB. Compania de Tenologia de Saneamento Ambiental. Relatório de qualidade de ar no Estado de São Paulo, 2008.

21 INTERGOVERNAMENTAL PANEL ON CLIMATE - IPCC. Working Group I. The Physical Science Basis, 2007. Disponivel em: $<$ http://www.ipcc.ch/publications_and_data/ar4/wg1/en/faq-1-3.html>. Acesso em: 15 maio 2010.

22 INTERGOVERNMENTAL PANEL ON CLIMATE CHANGE (IPCC). Chemically and Radiatively Important Gases. IPCC Fourth Assessment Report: Climate Change, 2007.

23 CONAMA. RESOLUÇÃO CONAMA Nº07, de 31 de agosto de 1993. Critérios para elaboração de Planos de Controle de Poluição Veícular.

24 CONSELHO NACIONAL DO MEIO AMBIENTE - CONAMA. RESOLUÇÃO No 418, DE 25 DE NOVEMBRO DE 2009, 2009.

25 ASSOCIAÇÃO BRASILEIRA DE ENGENHARIA AUTOMOTIVA - AEA. Inspeção vai exigir reciclagem de veículos no Brasil, 03/10/2009. Disponivel em: $<$ http://www.aea.org.br/pt_br/inspecao-vai-exigir-reciclagem-de-veiculos-no-brasil/>. Acesso em: 2010 abr. 09.

26 MEDINA, H. V. Centro de tecnologia mineral - CETEM. Reciclagem de automóveis, estratégias, práticas e perspectivas, Rio de Janeiro, 2003.

27 CORSINI, R. Processo e equipamento para alimentação de motores de combustão interna movidos a álcool. PI8402740, 1984. 
28 RODAGÁS. Adaptação da figura do sistema de Conversão Rodagás., 2010.

29 BOSCH. Catalogo técnico de injeção eletrônica. Manual técnico, 2008/2009.

30 VOLPATO, O. THEUNISSEN, F. MAZARA, R. Engine Control Module for Flex Fuel plus Compressed Natural Gas Vehicles. Pwetrain \& Fluid systems Conference and Ehibition San Antonio, no 2005-01-3777, 2005. Series, SAE Technical Paper.

31 AGÊNCIA NACIONAL DO PETRÓLEO, GÁS NATURAL E BIOCOMBUSTÍVEIS (ANP). Relatórios de Acompanhamento de Mercado. Disponivel em: <www.anp.gov.br>.

32 DAEWOO. Manual de instruções Lanos. [S.1.]: [s.n.].

33 VEIGA, M. R. Arquivo pessoal.

34 VOLKSWAGEN. Manual de instruções gol/Parati/Saveiro. [S.l.]: [s.n.], 2009.

35 BaZAnella, A. S. SILVA J. M. G.. Ajuste de Controladores Pid. Rio grande do Sul : UFRGS Universidade Federal do Rio grande do Sul, 2000.

36 MANAVELA, H. J. Controle Integrado do Motor. [S.1.]: Universidade de Buenos Aires, 2003.

37 NAPRO. O SOFTWARE de funcionamento dos Módulos de Injeção Eletrônica. Disponivel em: $<$ http://www.napro.com.br/index.php?option=com_content $\&$ view=article \&id=133\&Itemi d=68>. Acesso em: 10 out. 2009.

38 NGKNTK. Sonda Lambda, sensores de oxigênio. NGK NTK, 02 maio 2010. Disponivel em: <http://www.ngkntk.com.br/sens_ox/default.html>.

39 WARREndale, P A. Catalogo técnico. Automotive eletric/eletronic systems, 1988. Bosch.

40 US1. webpublications. Sensor de Fluxo. Disponivel em: $<$ Http://us1.webpublications.com.au/static/images/articles/i1094/109452_6lo.jpg>. Acesso em: 10 abr. 2010.

41 VDO. Depressão no coletor. catálogo técnico, 2008.

42 AA1CAR. Catalogo técnico AA1CAR, 2009. Disponivel em: <http://www.aa1car.com/library/maf_sensor_ford.gif>. Acesso em: 05 mar. 2010.

43 VEIGA, M. R. Simulação gerada no sofware Proteus PCB design., 2009.

44 PHILIPS. Datasheet LM258/358/A/2904, 2002. 
45 PHILIPS. Data Sheet. HEF40106B, 1995.

46 CILBRAS. Catalogo técnico Cilbras 2008, 2008.

47 INTERPRESS MOTOR. Idade média da frota nacional. Interpress Motor. Disponivel em: <http://www2.uol.com.br/interpressmotor/noticias/item21728.shl>. Acesso em: 15 jul. 2010.

48 DETRAN RJ. Departamento de Trânsito do Estado do Rio de Janeiro. Disponivel em: $<$ http://www.detran.rj.gov.br/_documento.asp?cod=91\#18>. Acesso em: 2010 jul. 01. 49 DIÁRIO OFICIAL DO MUNICÍPIO. LEI No 13.296, 24/12/2008 - São Paulo - SP. 50 INMETRO. Instituto nacional de metrologia normalização e qualidade industrial. Tabelas de Consumo / Eficiência Energética, 2010. Disponivel em: $<$ http://www.inmetro.gov.br/consumidor/pbe/veiculos_leves_2010.pdf>. Acesso em: 24 maio 2010. 


\section{APENDICE A}

Pesquisa dos preços dos sistemas de conversão em oficinas homologadas pelo Inmetro, preço dos equipamentos e da mão de obra de instalação.

Tabela 31 - Preços dos sistemas de conversão em São Paulo[33].

\begin{tabular}{|c|c|c|c|}
\hline Sistema aspirado & $\begin{array}{l}\text { Sistema com } \\
\text { injeção Positiva }\end{array}$ & Convertedora & Contato \\
\hline 1740 & 3850 & Gas Point & www.gaspoint.com.br \\
\hline 1600 & 3500 & Intersul & intersulgas_2@ig.com.br \\
\hline 1800 & 4550 & autogasgnv & www.autogasgnv.com.br \\
\hline 1750 & 3575 & systemgas & $\underline{\text { www.systemgas.com.br }}$ \\
\hline 1750 & 4696 & $\begin{array}{l}\text { retifica motor- } \\
\text { vidro }\end{array}$ & Isaac@ retifica.com.br \\
\hline 1500 & 3500 & HP7 & hp7sor@terra.com.br \\
\hline 1500 & 3500 & autocheckup & www.autocheckup.com.br \\
\hline 1500 & 3500 & Fernando Fossi & fernando.frossi@uol.com.br \\
\hline Preço médio & Preço médio & & \\
\hline 1642,5 & 3834,0 & & \\
\hline
\end{tabular}

\section{ANEXO A}

Na Figura 66, é apresentado o documento de licenciamento do Daewoo Lanos, com a modificação do combustível para gasolina, etanol, e GNV.

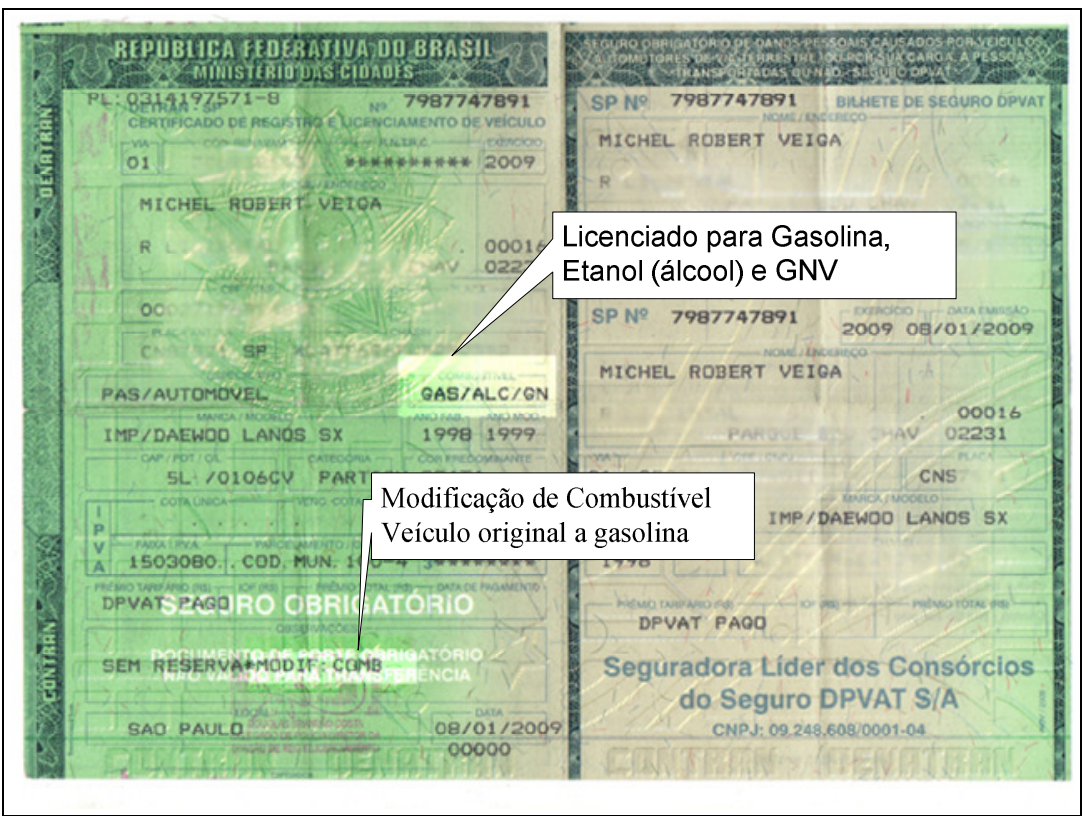

Figura 66 - Licenciamento do Daewoo Lanos tricombustível[33]. 


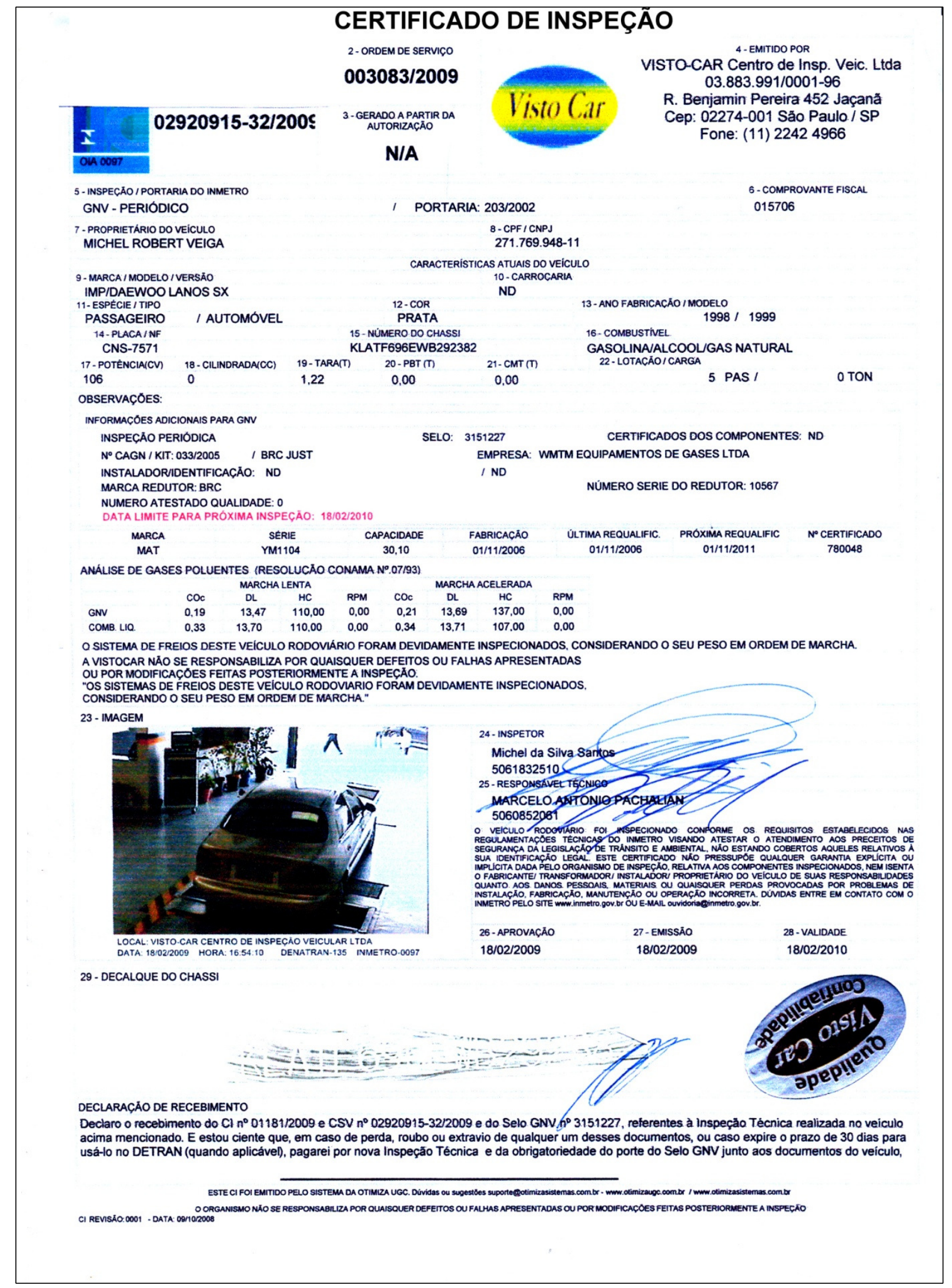

Figura 67 - Certificado de inspeção veículo do Daewoo Lanos[33]. 


\section{ANEXO B}

Na figura 62, é apresentado o documento de licenciamento do VW Gol com a modificação para tricombustível e, na figura 63, o comprovante de inspeção veícular municipal.

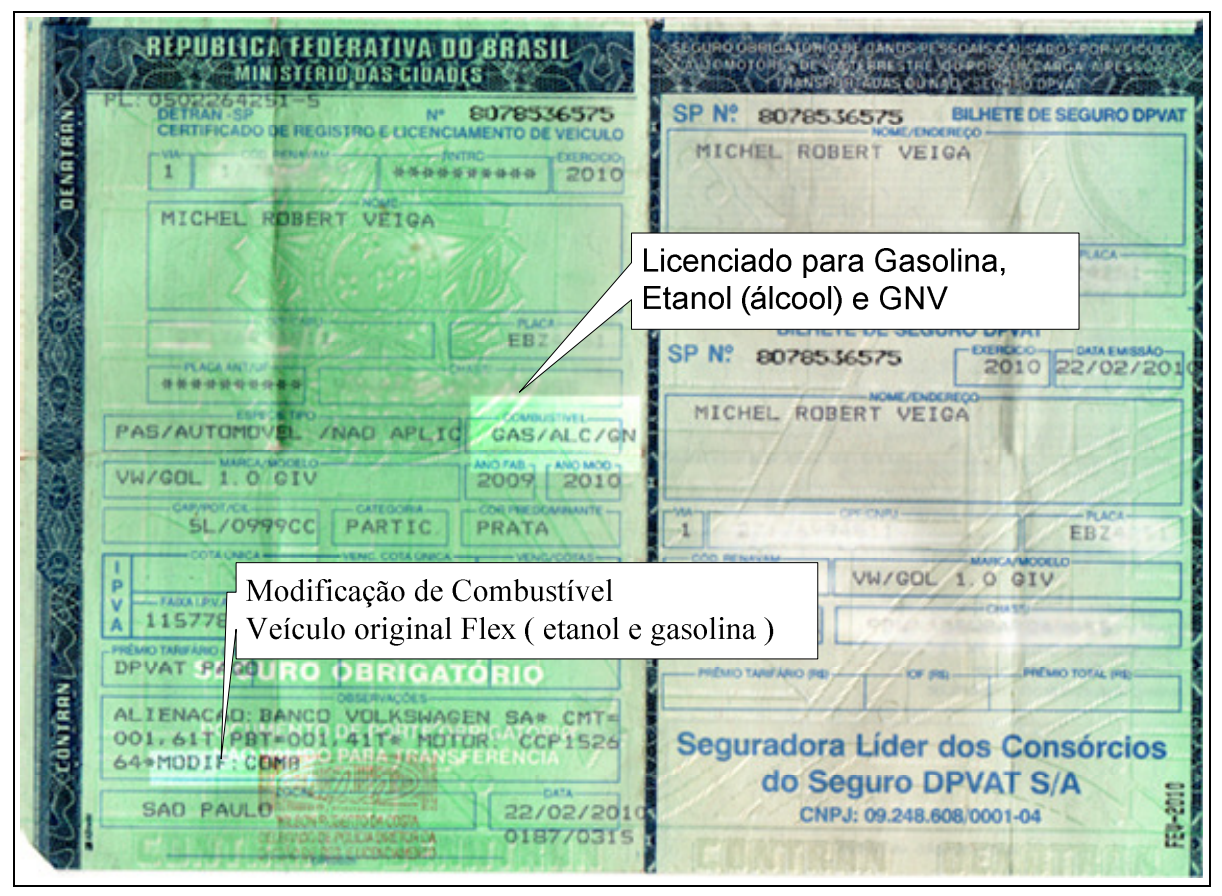

Figura 68 - Licenciamento do VW Gol tricombustível[33].

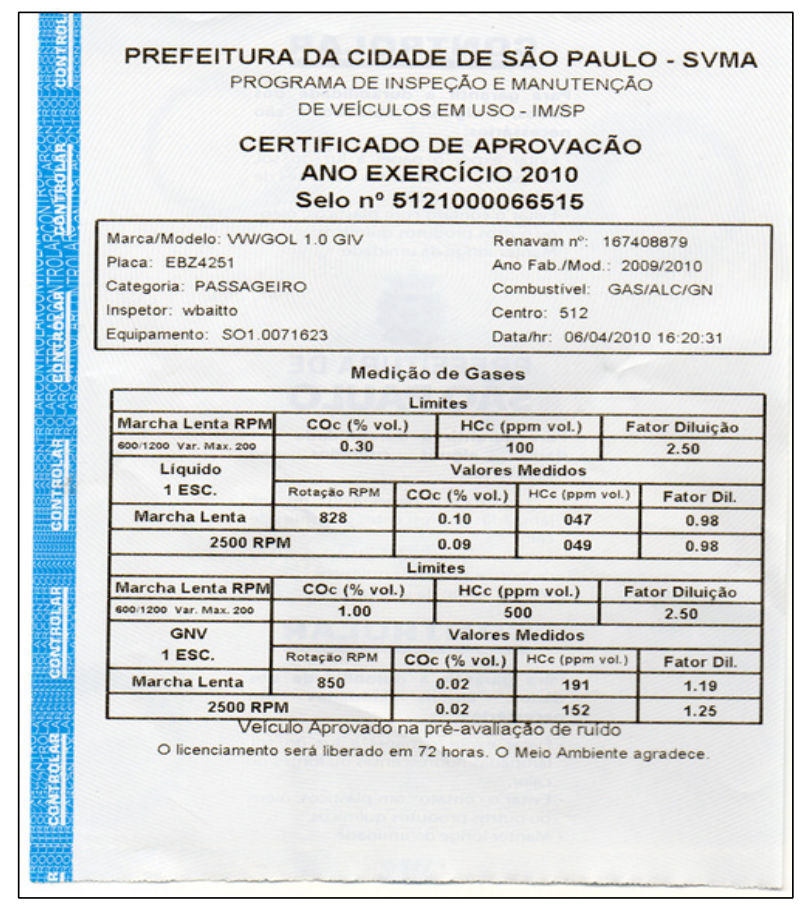

Figura 69 - Certificado de aprovação de inspeção ambiental[33]. 
$\mathrm{Na}$ figura 64, é apresentado o certificado de inspeção inicial para o VW Gol para tricombustível.

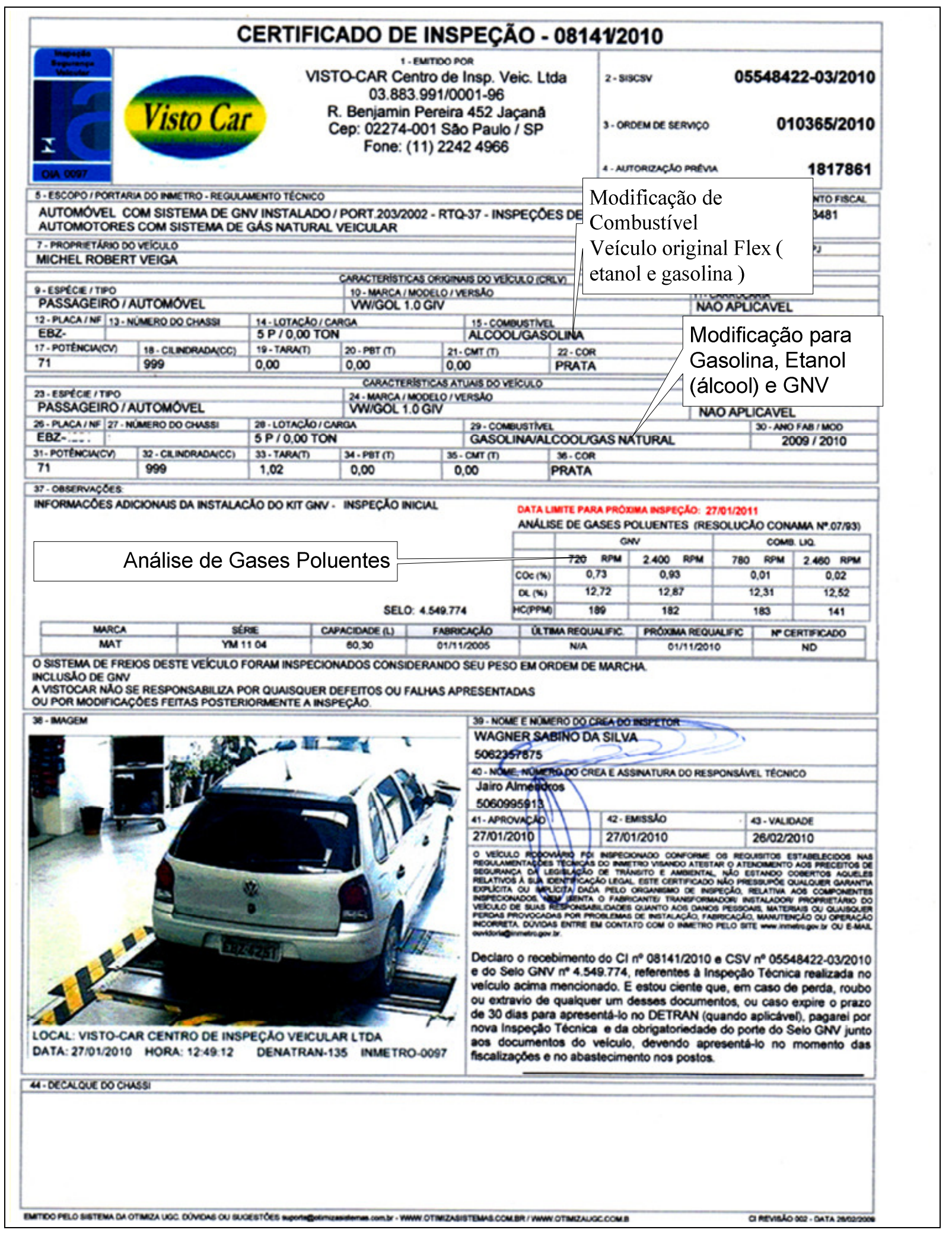

Figura 70 - Certificado de Inspeção inicial, VW Gol [33]. 